1

WMALING

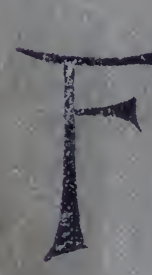

ISH
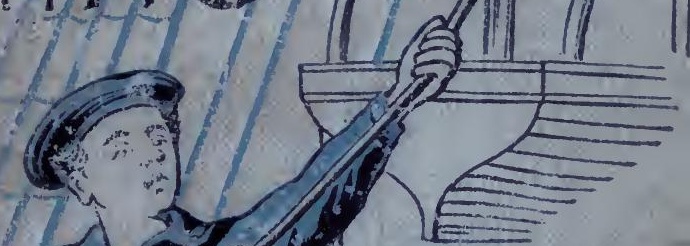

7.

1

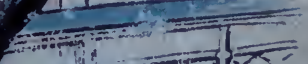



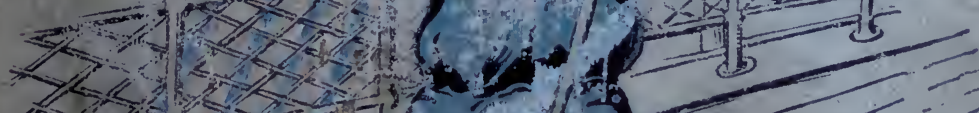

$763+n^{2}$

27
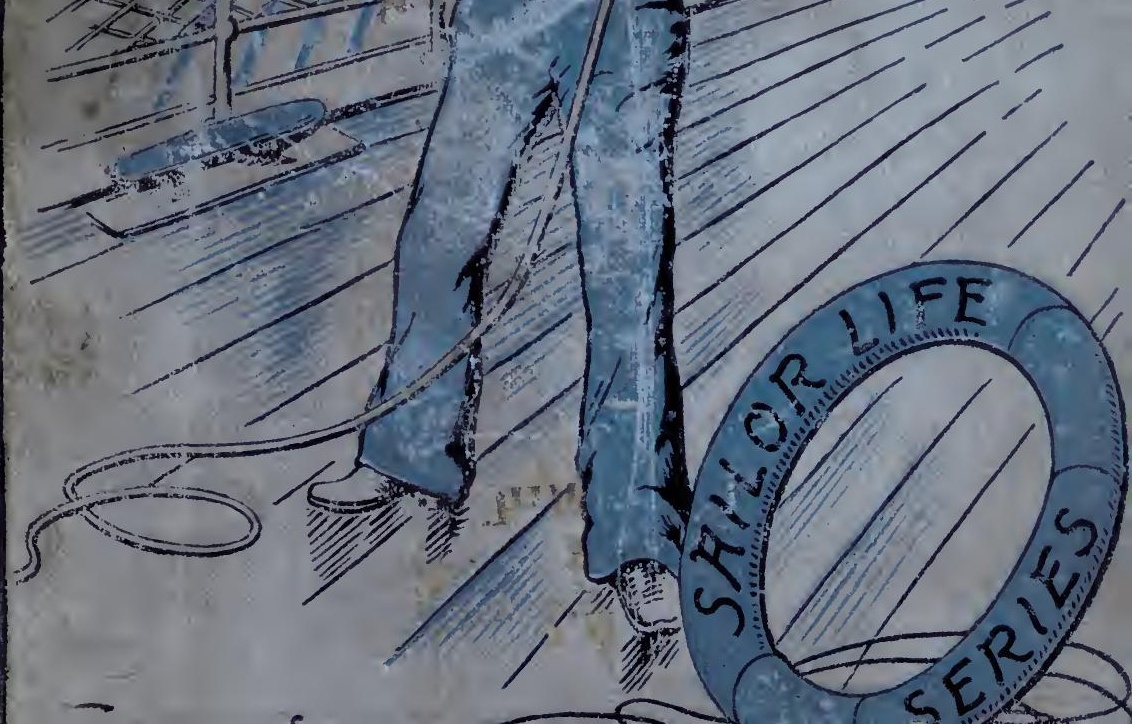


$-$
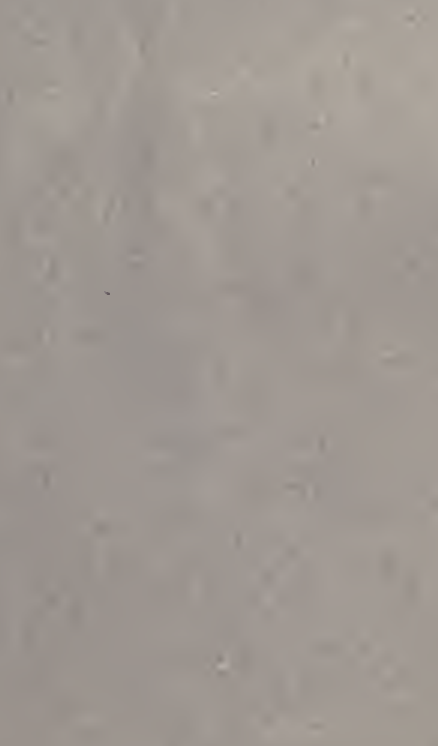


\section{WHALING AND FISHING.}

BY

CHARLES NORDHOFF, AUTHOR OF "MAN-OF-WAR LIFE," "THE MERCHANT VESSEL."

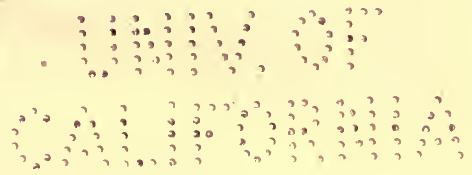

NEW YORK :

DODD, MFAD \& COMPA NY, Publishers.




Entered according to 'Act of Congress, in the year 1855 , by MOORE, WILSTACH, KEYS \& CO.,

In the Clerk's office of the District Court of the United States for the Southern District of Ohio.

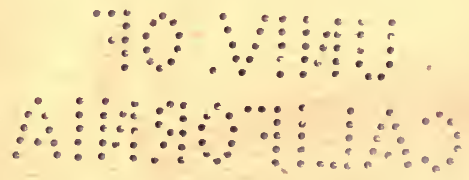




\section{P R E FAC E.}

Wite this volume my story of life at sea 8 complete. I have endeavored to give a strictly faithful account of the various phases of a sailor's existence. I have borne in mind the usual objection to books of this class: that they are likely to inspire youth with an uneasy longing for a wandering, worthless mode of life. And as my little books were likely to interest young men and wurs, my aim has been to give a plain com. mon sense picture of that about wnich a false romance throws many charms. If anything $I$ have written on this subject skall induce a young man, launching into life, to make a sensible choice of evils, by looking elsewhere than to the Sea for the adventurous existence which his spirit requires, I shall be rewarded.

(iii.)

\section{ํ. 23588}





\section{ONTENTS.}

\section{CHA PTER I.}

Whalemen Wanted! A Whaling Shipping Office-The Man-of-Wars-man - The Merchant Seaman - The Whaleman-Talk with the Shipper-l determine on a Whaling Cruise - Go to New Bedford. - -

\section{CHAPTER II.}

New Bedford - The Town - The Wharves _ The Shipping Office - Prospective Whalemen - Old Bill - The Outfitters - Tricks upon the Greenhorns - Hezekiah Ellsprett - Claims the Captain's Stateroom-Old Bill and the Ship-owner - The Transformation.

\section{CHAPTER III.}

The Sag Harbor Whalemen - Shipped at last-Arrangement of a Whaleship's Decks - The Try Works - The Boats - The Lower Deck — Sailing Day - Our Crew Seasickness - Training the Greenhorns - Labors of an Outward Bound Whaleman - Drudgery.

\section{CHAPTER IV.}

Land Hc: Fayal - Anxiety of all hands to get ashore Portuguese - Their resignation - Fruit - We continue the voyage - Fitting the vessel for her cruise — Drilling . the crew in the boats - The line - Chasing Blackfish -. Provisions-Cooks 


\section{CHAPTER V}

Sabbath - Our Captain's Whaling experience - Land Ho! The Scene of a battle - Tristan d'Acnnha_The story of its settlement - Governor Glass - 'The internal econ. omy of the settlement-Intercourse with shipping -General apperrance of the Island - A wreck - An exciting race - Madagascar or Malaga? - - .

\section{CHAPTER VI.}

The "Cruising Ground "-What constitutes W'ıale Ground - How the Haunts of Whales are Discovered - The Discipline of a Whaleship on a cruise-Monotony of the Life-Drawing Water - Portuguese Man-of-war - Cape St. Mary's, of Madagascar-Raising a Finback"There she blows" - A false Alarm-Sperm Whales -Preparation for lowering - "Going on to a Whale" "Give it to him!"--The Whales run - The Chase The last Desperate Effort, and accompanying Mishap - "Getting stove" - A furious Whale - We are picked up, and lose the Whale. -

\section{CHAPTER VII.}

Fitting a new Boat - We raise Whales again - Our Boat gets fast-The Whale takes out the Line - The Mate despairs-Sunset-- The third Mate refasten:-The Mate kills the Whale - "There's Blood" - The Flurry Getting a Fish alongside-Cutting in - Wrenching off the Head-The Teeth - The Junk - The CaseExtraordinary gathering of Shark8-Their Rapacity - Trying out, - Horse-pieces - Blanket-pieces - Mincing - Division of Labor-A Night Scene-Nauseating Labor - Picking out fat-lean - Stowing down the Oil Clearing up Deeks. - 
CHAPTER VIII

"Gamming" - Sail Ho! - The Betsy Ann-Her CrewA. "Merchant Sailor" - A Council - A school of Whales -A race between two Whale boats - The Offer to share the Chances refusel-It is our Whale-The Barzaroota Islands - Procuring Wood-A strange FishHarpooning Hippopotami-We cause one to "spout blood"-Tow it Ashore-Hippopotamus Steak-A Night Visit to the Shore for the Purpose of Killing a few Hippopotami, with its Results. - _ - - 138

\section{CHAPTER IX.}

No Whales - Tediousness of the Life - Expedients to kill Time-The Habits of Sperm Whales-Their FoodThe Sperm Whale Squid - Its Arms-The Whale's Teeth, and how it is supposed that he uses them-Means of Defense possessed by Whales - The right Whale - The Humpback - Quickness of Motion of a Sperm Whale Lowering in a Calm-Difficulty of approaching a $\mathrm{W}$ hale at such a Time-He Listens - Sudden disappearance Chasing a gallied Whale - Rainy Weather - Bourbon Determination to leave the Vessel at the first Opportunity - The Coast of Madagascar - A Story of St. Mary's Shoal.

\section{CHAPTER X}

domething further concerning the habits of Whales The Humpback - Their liability to Sink when dead Antongil Bay - Our Anchorage - The denizens of the Jungle-Our first Whaling day - A Word concerning the Weather-Actions of Whales-Close of the first Day - The Night - Another Deluge - We get fastThe Whale spouts Blood - Tenacity of Life-Towing dead Whale - Cutting in - Trying out-A "Cow sn 
a Calf ")-Strong affection of the Mother.Whale-How Whalemen take advantage of this - The Calf is killed - The Sharks eat up our Whale - Scaring a Humpback Its Results.

\section{CHA PTER XI}

antongil Bay, continued-Whaling near Desolation Island -Teddy-A Character-Sea-Lions-How they are Captured-Tannanarevou-A Citý on a hill top-The Natives - The Scurvy-Burying a Man-Nearly a Ghost Story - The Cook's opinion of Ghosts - Attempts at explanation, meet with no Favor - The Result - Preparing to leave the Bay - Our first and only Holiday in the Bay-A Tour of Exploration-Disturbing an Ant's nest - Flying Foxes - We proceed to Sea. - - - - 194

\section{CHAPTER XII .}

St. Mary, Madagascar-Applying for Liberty - It is granted - Sickness Ashore - The Town and Fort-Two Men remain over night-They are taken sick and dio . - An Auction - Reflections - The Seychelles-Plans for leaving the Vessel - We raise a School of Whales How a dead Whale makes headway against the Wind Striking a Finback — "There blows"-The excitement of "going on" to a Whale-Fast and Loose-A Whale's Revenge - The Boat Stove. - - - - - 210

\section{CHAPTER XIII.}

Mahe-A Newspaper-The Islands-Their Inhabitants-A lazy man's Paradise-Plans for Escape-George Thompson's Yarn - A Cruise in a Whale boat - The Escape Sailing alorg Shore-The Arrival at Mozambique - Conoerning Attempts to Desert from Whaleships - Some Reasons for the Frequenc of such Attempts. - - 281 


\section{CHAPTER XIV.}

"Liberty"-The Massowah Vessel - She wants a Hand - I go alongside - The Vessel is searched - We sail The trip to the Mauritius - The Crew - The Captain Discipline_The Land - Port Louis Harbor - I gain an unexpected Friend-I take charge of the Captain's Boat-A trip to Tombo Bay - Paul and Virginia - The Island-Its state under the French-Under British rule-Malabar Apprentices-Malabar Town-The Natives - Chinese. -

A Touching Ceremony-A Sailor's Grave-I turn Boatman -Life in the Isle of France-Seeking Employment-Joe Rodgers-A Bullock Drogher-Tamatave Bay - The place of Sculls - Hump cattle - Our return Passage Taming wild Cattle - Sancho-His docility - Meeting Ashore - Difficulty of leaving so warm a Friend-A Wedding.

\section{CHAPTER XVI.}

The Annie - Her Captain - I Ship in her - Our Crew -

A Clipper's Forecastle - Sleeping Dis-accommodations —Steering - "Humbugging"_Planning a Mutiny - Counter Planning-The African Coast-Algoa BayThe Anchorage - Surf-boats - Cape Boors - A South Easter - A Double Wreck - Lloyd's Agent. - -

\section{CHAPTER XVII。}

Coasequences of the Wreck-A New Crew-Scotch English - Uses of a Barometer - A South-easter Squall -Return to Port Louis_-Ship for England-The Pauline Houghton - Talking to the Mate-Our Crew - Paddy -An examination in Searnanship - The Ship-Her 
rotten rigging - The Captaiy's daily siesta - The Mate gets himself into trouble-How to gain the respect of a tyrant-Shooting at a mark - The Trases - Paddy's last torture-Short 'anded-Sufferings - Kecuperating-Seeking a Berth-The last act of Tyranny Paying off-A "Recommendation."

\section{CHAPTER XVIII,}

I wait for the Barque-Disappointed_- Working" a Passage - New York after two yea:-3' Absence-Coasting Cape Men-Smyra, the Cook-Our Crew go Home-Ship Keeping--Solitude leads to Reflection-A “Coaster's Life -A "Stranger"-The Cape-The Mary Hawes-A "Fish Crew"-Fishing "at Half Line"-We SailPreparing for Business - The Vessel — Her Captain. 349

\section{CHAPTER XIX.}

"The Fleet"-A" Night Scene-The First Day on Fish Ground-Habits of Mackerel-Advantages of being in a Fast Vessel-Why there is a "Fleet"--Method of Taking Mackerel - Bait used - Monotony of the Fisherman's Life-A Fish-day_Premonitory Symptoms_Rain - "Shorten Up"-Breakfast_Dressing Fish_Making a Harbor - Salting down - Coming to Anchor - After Supper Comforts - The Morning after a Storm-The Close of the Trip-Depart for New York-I Determine to quit the Sea- nd do so-Difficulties Attending such change with the Sailor. 


\section{WHALING AND FISHING}

\section{CHAPTER I.}

* mancar WaNTED!-A Whaling Shipping Office-The Mas. 1T-warg-man-The Merchant Seamen-The Whaleman-Talk तith the Shipper-I Determine on a Whaling Cruise-Go to wiow Beartord.

"Lannsmen Wanted!! ONe Thousand STOUT YOCNG MEN, AMERICANS, WANTED for the fleet of whaleships, now fitting out for the North and South Pacific Fisheries.

"Extra chances given to Coopers, Carpenters and Blacksmiths.

. "None but industrious young men, with good recommendations, taken. Such will have superior chances for advancement.

"Outfits, to the amount of SEVENTY-FIVE DoLLARS furnished to each individual, be. fore proceeding to sea. 
"Persons desirous to avail themselves of the present splendid opportunity of seeing the world, and at the same time acquiring a profitable business, will do well to make early application to the undersigned."

Such were the contents of a flaring poster, whose bright capitals caught my eye, as one morning I was rambling with a shipmate along South street, on the East River side of New York. Such notices are no rarity in the Eastern seaports. "Whale crews." are in almost constant demand, and these "Wants" and "Fine Chances," stare one in the face on nearly every street corner. They are the lures by means of which the farm-boys, the factory-boys, and the city-boys are drawn to the net of the shipper. The very hopeful, and delightful, but somewhat overdrawn picture of a whaleman's life, here in few words set forth, has enticed many a tolerably honest, but withal lazy lad to seek the shipper's office, and engage himself for a three or four years cruise.

To a sailor this avenue to a whaleship is hermetically sealed. Neither here nor in New Bedford is he at all likely to be shipped - for experience has taught the captains and owners of whaling vessels that your real tar is too uneasy a creature to be kept in good order for so long a cruise as whalemen now-a-days generally make.

Knowing very well that the shippers will not 
engage them, it is no uncommon amusement with sailors, to step into one of these whaling slupping offices, and make all manner of inquiries 'concerning the business, the pay; the prospects of enceess, and finally perhaps, to offer to engage iliemselves-at which last stage the agent gener. ally breaks off all communication by informing his mischievous visitors that he has at present no chances open.

"Here's the office, Charley," said my shipmate, who had been amusing himself at the expense of one of the bright posters we had passed. "Let's go in and talk a little to the old fellow. I'll ask him if he don't remember shipping me as boat. steerer in the Happy-go-lucky."

"You don't look green enough for a whaleman, Jack," said I.

"No," answered he, giving his trowsers an extra hitch, and his rakish little hat a more knowing set, "there"s no green here, lad; but come in."

We stepped into a tolerably roomy office, divided into two unequal parts by a railing, behind which stood a desk, upon which leaned a tall, blackbearded, shrewd looking man. This proved to bo the shipper, or shipping-master, as this dignitary is styled by seamen. The front and largest divisiun of the office was furnished with several long forms or benches, ranged along the wall, some hairs, and an occasional spit-box. On the benches reclined at full length three as verdant specimens of humanity as could be easily conseived of. Dirty, 
lazy looking wretches they were, withal, whose begrimed faces, and filthy shirts betokened a most inconsistent aversion to the element upon which they were about to seek their fortunes. One of them I noticed had already taken the initiatory step in sailorship-his mouth was filled with to. bacco, and the saliva was trickling from the lower corner, to the floor beneath.

"Industrious young men, with good recommendations," muttered my companion, in a rery audible whisper.

The shipper evidently looked upon us as rather unwelcome intruders, and did not hesitate to tell us: that there were no chances to ship.

"Don't you want to ship a good Boatsteerer?" asksd my friend, in reply to this hint.

"Do you mean to say that you were ever whaling?" was the Yankee answer to this. The accustomed eye of the shipper had seen at first glince that neither of us were whalemen; and had we disguised ourselves with all possible care, he would still have been as sure as before, of this. It is a singular fact, that seamen, as also those who bave much dealings with them, can tell, almost at a single glance at a sailor, and with the most unorring certainty, what special department of his business he has most generally followed. What may be the actual distinguishing marks, it would be diffirult to say. But they are there, plainly visible to the initiated, and unconcealable by any but the most experienced old seadogs, who, havirg 
seen a little of all services, sometimes succeed in making themselves a puzzle, even to :he discrim. inating vision of the shipper.

Of these distinguishing marks it may be said however, that the man-of-wars-man is known, by a certain jaunty neatness of attire, and a some thing dashing, and carelessly gay, in his air ana manner, which is above all others his peculiarity. Let him dress as he will, he can never drop that air of saucy recklessness.

The merchant seaman is rough, weatherbeaten, with hard features, face and neck bronzed by many suns, and hands swollen by hard work. Put he is more particularly distinguishable by an indiscribable awkwardness, in manner and gait. Toil and exposure have made his body stiff and clumsy. His tout ensemble presents more angularities than that of his brother of the service, and in his motions he displays none of the easy grace of the latter. Withal, his clothing fits him badly. The most skillful tailor gives him up in despair, and he lumbers through the world with an ungainly roll, which somehow puts one in mind of a bear. It 18 in storm, and danger, "in the times that try men's souls," that Forecastle Jack shows to adrantáge.

But how shall I describe a whaleman? that walking embodiment Rag-fair - "patch xpon patch, and a patch over all." While Jack and I are taking a survey of the office, there comes in a fair specimen of the genus. "He is a boatsteerer"-- 
tho shipper whispers to me as he sees him enter the door; and he is probably a smart fellow, else would he not be cordially welcomed in and atten. tirely listened to by that worthy.

$\mathrm{He}$ is a rather slender, middle-sized man, w:th a vory sallow cheek, and hands tanned of a deep and enduring saffron color. He is very round-shouldered, the effect possibly of much pulling at his oar. $\mathrm{He}$ has a singular air of shabbiness about him, as though he had bought his fit-out in Chatham street, of some dealer in second-hand garments. Neither does he look at all at home in the "shore 3lothes" which he carries about. His shoes are rough and foxy, and the strings trail upon the ground, as he walks. His trowsers fail to connect, oy several inches, showing a margin of coarse, grey woolen sock, intervening between their bottoms, and his shoes. A portion of his red flannel drawers is visible, above the waistband of his pantaloons; while a rusty black handkerchief at the throat, fastened by a lárge ring, made of the tooth of a sperm whale, and inlaid with mother. of-pearl, keeps together a shirt bosom, which is innocent, of a single button. A cutaway coat of summer-cloth, and a little glazed cap complete his costume. But that which strikes one as his most márked peculiarity is a certain uncertainty in his gaze, which seems to betoken a lack of self-confidence. He moves along with a spiritless dawdle, which is quite in unison with his general expression of list. lessness. He evidently feels but ill at ease in 
sicas and stockings. He speaks in an undertone, 9.S though not judging it worth while to talk louder. His appearance is thoroughly unprepos. ressing; and calculated to give one the impressio that he is quite the reverse of "smart."

This is a whaleman, ashore.

"Who is he?" I asked of the shipper, as ine lounged out of the office door, after receiving some money, evidently the object of his visit to the shipping-office.

"That fellow," was the answer, spoken with some degree of pride; "that's Ezekiel Wixon, a mighty smart man, I can tell you, and death on a sperm whale. I've got him a birth as third mate and boatsteerer in the finest ship that will sail from New Bedford this season, and I would not hesitate to bet money that he will be chief mato of her next voyage."

I should never have guessed it, from his appearance; but it was even so. And when I subsequently came to New Bedford, I found this awkward looking fellow hand-in-glove with every out-fitter in the place-a sure sign that his smart. ness as a whale-man was beyond doubt.

While I was talking to the shipper, my com. panion saw something in the street to attract his attention, and left me. Being thus w thout company I continued my conversation with the talkative shipping-master, gaining from him some information in regard to a brancin of the whaling business, of which I had hitherto learnt but little. 
He explained to me how and on what terms the greenhands, or landsmen, as with a proper respect for the income they produced him he preferred to call them, were engaged, as well as many particulars then heard by me for the first time, in regard to the manner in which "the hands" are fitted out for a whaling cruise.

There are shipping-offices in all the principal American seaports, as well as in some of the cities bordering on the lakes. Each of these offices has its headquarters at New Bedford or some other of the whaling ports, and thither such men as they can pick up, are sent, at the risk and expense of the shipper. On their arrival, they are taken in charge by the resident agent, who provides them with boarding houses, and next proceeds to procure for them places on board some outward bound vessel. The shipper charges ten dollars per man for his services, besides having his outlays refunded him. These expenses, as well as board bill for the time the prospective whaleman is obliged to remain in port, are included in the seventy-five dollars outfit which figures so conspicuously on ae posters before mentioned.

As neither shippers nor outfitters recerve a cent from the owners till the vessel is fairly at secw, it behooves them to pick out the steadiest looking inen. Frequent loss has taught them to regard the fickle-minded sailor with a large degree of aversion, and to cherish a corresponding degreo of good feeling toward every degree and kinr 
of verdancy, from that of the farmer boy: to that no less evident, of the "counter-jumper"

"In fact," remarked the shipper to ne, "it would never do for us to bring sailors to a whaling port, for the owners will not take them in their chips. You old salts are an unquiet set, and never make good whalemen."

With a smile at his opinion of sailors, I took my leave of the shipper. His account of New Bedford, which was his chief scene of operations, had aroused my curiosity to see somewhat of a whaling port, and I began to think seriously of taking a trip thither in some little coaster, and spending some weeks there. I had still money ewough-why not indulge this whim?

As I walked along, ruminating upon my plan, an old acquaintance, a captain of a coaster, with whom I had made a voyage once before the mast, accosted me,-and after shaking hands, and a hearty inquiry after my welfare, asked me if I would not go with him to New Bedford.

"I'll only want a man to help me as far as there, where I have now one of my old hands, waiting for the vessel (a little schooner), and I'll give you five dollars for the run."

"Agreed," said I, without stopping to take a wocond thought; "when do you sail?"

"To-morrow morning, with the first flood."

We walked down aboard the schooner, a neat little craft of some sixty tuns, and talked over old times for a while, when I returnea to my 
bos.rding house, to pack up my luggage, and pro. pare myself for the morrow. On mature consideration, I determined to take all my effects slong with me, so that should I make up my mind to ship for a cruise in a whaler, I should bo prepared.

Accordingly on the following morning, I bade good-by to the few ship-mates whom I had met while in New York that time, (but without communicating to any one of them my thoughts concerning making a cruise in a whaler), and took my chest and hammock aboard the schooner. The tide serving soon after I got on board, we cast off from the pier and stood up the river, amid a fleet of coasters, all bound through Hurlgate, and up "the Sound." It was a fair day, in midsummer, and as we sailed along with a pleasant breeze, my old shipmate, the captain, or skipper, as he was most generally addressed, sat himself down by me to have another talk over days past, when we were together inmates of a forecastle, and to hear somewhat of my adventures since.

"But why dicl you bring with you all your things, Charley?" said he, when at length I had hrought my yarn to a close.

"Well," I answered, with some degree of hesitation, for I was half ashamed to disclose my thoughts even to an old friend, "I have half an idea cf shipping in a whaler."

"I hope you won't make such a fool of your velf, my dear fellow," was the answer to this 
"Ai any rate," continued he, "there's but little danger of it, for no owner or captain in New Bed ford, would ship such àn old salt as you."

Now, I may as well own here, that this con. tinued assertion, that $\mathrm{I}$ would not be able to obtain a birth in any whaleship in New Bedford, had the effect of adding much strength to my at first but weakly entertained wish. The more insurmountable seemed the difficulties which hedged about my undertaking, the more earnestly it took hold of my mind, and the more desirable did its attainment appear to me. And thus it came about, that before we reached New Bedford, I was firmly resolved to leave no avenue untried, in my effort to obtain a piace on a whaler. It must not be supposed however, that the wish to make a trial of whaling, and add this to my experiences of sea life, was altogether of so late a date as the previous day. On the contrary, I had long entertained the determination to make a whale cruise at some time or other, and every whaling yarn spun in a forecastle served to keep alivo this thought. But I had never before now set a time and place fior the carrying into effect of this idea 


\section{CFAPTER II.}

Wrw BeDFord-The Town-The Wharves-The Shipping Offiow -Prospective Whalemen-Old Bill-The Outfitters-Tricks upon the Greenhorns-Hezekiah Ellsprett claims the Cap. tain's Stateroom-Old Bill and the Ship-owner-The Transformation.

We arrived in New Bedford after a short and pleasant run of twenty hours through the Sound. As soon as the vessel was anchored opposite the wharves, I persuaded the cook to set me ashore, and proceeded to seek a boarding house, and take a preliminary survey of the town.

I experienced no difficulty in securing a place where, for a very moderate sum per week, I was to be furnished with what the good lady called "lodging and victuals," and, after getting my luggage ashore, and receiving the five dollars due me for helping to work the schooner to this place, I set out on a ramble over the town. This I found to differ in many particulars from any other American seaport I had ever been in, and, indeed from any conceptions I had formed in my own mind of its general appearance.

For a place in which so large a business is car ried on as here, "Bedford" is remarkably still At the distance of three squares from 
side, one would never guess that he stood within the bounds of a city which ranks in commercial importance the seventh seaport in the Union, and whose ships float upon every ocean. A more quiet and rural looking place than that portion of the sity beyond the immediate business limits, it would be difficult to imagine. And a more beau tifully laid out or better kept city I never saw. It was now mid-summer, and the spacious mansions embowered in green foliage, which border the principal streets, looked really enchanting to my eyes, long wearied with monotonous salt water views; while a walk up the well shaded streets was like a trip into the country. New Bedford well deserves the name of being one of the most heautiful cities in New England.

The business portion of the town is confined within a comparatively limited space. One long street, running parallel with wharves, is almost exclusively devoted to the shops of the outfitters, who play a far from unimportant part in the drama of whaling, and of whom more particular mention will be made further on. On the littl branch streets by which this main street communicates with the water side, the sailor boarding houses are mainly found. Many of these aro kept by the widows of departed whalemen, who earn a scanty subsistence by providing the afore. mentioned "lodgeing and victuals" for numer. ous youthful aspirants to spouting hourors, whe here do congregate. 
liassing by the boarding houses, we come to the wharves, along which, fronting the water side, are the warehouses and counting rooms of variJus ship owners and dealers in oil, bone, and spermaceti. These are scattered along, without regular connection, the scene varied here and there by a blacksmith's or cooper's shop, which two branches of industry seem to be in a pecu. liarly flourishing condition hereabouts.

Looking down to the water now, we see a fer straggling wharves, between which lie numerous vessels in various states of readiness and unreadiness for departure on their long voyages.

Here lies a huge hull, careened over on the flat, her exposed side and bottom being thoroughly resheathed and new coppered, dozens of men crawling all over her vast bilge, sawing, fitting, and hammering. Yonder is an old hulk, whose topsides have been torn away, to make room for new ones, by which means she will become almost as strong as a new vessel. Here, at the. wharf, is a craft in a more forward state; her masts are now being put in, and as we are looking at her, a general shout proclaims that the main-mast has just been stepped. And a little farther on we see a rusty-looking old tub, just being converted into a saucy clipper by the aid of a plentiful application of paint.

All is life, and wherever the eye rests the scent is one of ceaseless activity. Yet there appears none of the hurrying, bustle, and in particular. 
none of the noise which is a disagreeable attendant on all business about the wharves of other large cities. In this, more than aught else, New Bedford differs from any other American seaport.

The stranger, placed on these wharves, in ignorance of his locality, would not long be without the material on which to predicate a reasonable guess. At every few steps, all locomotion is hin. dered or obstructed by long tiers of huge, dirty casks, redolent of train oil, while ever and anon, one stumbles over a bundle of whalebone, or brings up against a pile of harpoons, lances; boatspades, and other implements for dealing death to leviathan-all of which proclaim "in language not to be mistaken," the calling of the place. With here and there a patched, weatherbeaten whaleboat, turned bottom up upon the shore, and an occasional pile of oars, the view is tolerably complete.

But I imagine the wharves of New Bedford would be incomplete without a due sprinkling of prospective whalemen, wandering listlessly about, looking up with silent wonder at the, to them, vast hight of the ships' masts, or perhaps sagely inquiring "when the apartments for the gailors will be ready for their reception?"

My first day in New Bedford was devoted to a lengthened stroll through the city, and over the wharves. I satisfied a curiosity long entertained, by a close examination of several whaling vessels, just come home, or being fitted for a cruise, and 
there remarking in what the general arrangements of the decks and rigging of a "blubber-hunter" differ from those of a merchant clipper. By the time I got my breakfast on the following morning, I had fully determined to ship here for a whale cruise. My first object, therefore, was to make the acquaintance of some one of the shippers, and induce him to use his influence in procuring me a berth. Having obtained directions to the most extensive shipping establishments in town, I called in, in the course of the forenoon, to settle the preliminaries, and inquire as to the terrns on which men were engaged.

Turning down one of the little by-streets which lead from the main street to the water side, I came upon a large building, evidently once used as a factory, which I saw by a conspicuous sign over the principal entrance, was a "Shipping Office." Entering, I saw before me, in a very long room, about sixty young men, some lying down upon the bare floor, some lounging upon boxes, and a few, sitting in a corner apart, having a stealthy game at cards. A few were reading, but the greater number were whittling pine sticks, and keeping up a running fire of low ribaldry, wherein the most vulgar was evidently the best liked. These were embryo whalemen, the prospective slayers of countless leviathans, the humble instruments of shedding no inconsiderable quantity of light upon their country.

Some I noticed, had already donned portion 
of their out-fit, and strutted about in linsey woolsey shirts, ill-fitting pepper-and-salt trowsers, and glazed hats; evidently producing quite an impression upon themselves, as well as upon thcir less fortunate comrades, who not yet having shipped, were compelled to retain their now heartily despised "longtogs."

Very few among them had beards. Most of them were very young men, or rather, overgrown boys-already too large ever to become good seamen-but just at that age when they would contract all the vices of the sailor, without gaining one of the good qualities which, in Jack Tar, sometimes go far to sounterbalance and cover up his multitude of sins. I felt sorry for these striplings, thus sundering themselves from all the restraints of civilized life. There were among them some intelligent faces, and a few, a very few-not more than two or three of the fifty or sixty present-who bore in their countenances and their manners the unmistakable evidences of careful and moral training.

Most of those before me had already made a beginning upon the paths of vice, and for them the sea was pleasant only in so far as they thought to find in a sailor's life a larger license than thr laws and customs of the shore permit.

I was not long in the hall, ere I found my. self an object of very general attention, its inmates evidently guessing at once, that I was a sailor, the ger uine article which some of them 
were so ridiculously attempting to counterfeit. was comical to see how closely they watched my erery movement, each endeavoring to copy some particular air or way, which, above all else, struciz him as still necessary to render his own appearance that of a regular built Jack Tar.

While I was yet watching their maneuvers, one of the crowd, hitching up his pantaloons, which threatened every moment to fall down over his hips, waddled up to me, and adjusting his hat as nearly after the sailor manner as he was able to at the moment, said:

"I say, sir, you're a sailor, are you not?"

"That's the best guess you've made since you cast loose from your mammy's apron-strings, greeney," said a jolly voice at my back, whose tones seemed somehow very familiar to my ear.

I turned quickly in its direction, but had scarce faced the speaker, when I felt myself encircled in two huge arms, and the breath nearly squeezed out of my bodv, while a stentorian voice hallooed almost in my ears, "by the great hook-block, it's Charley."

When I got myself out of the bear-like exbrace of my huge friend, I found that he was -au old shipmate-a topmate during the greater part of a three years cruise in a man-of-war. Of course, our meeting was deemed a fortunate one by both of us, and Bill at once proposed to celebrate it by a glass of "the very best liquor you over drank, Charley." 
1 persuaded my old friend to postpone the drinking, and we locked arms and took a walk alcng the wharves, during which we talkec over cld times, compared notes as to our various adven. tures since we had parted, some three years before. and I finally learnt what had brought him to New Bedford, the very last place where I should have expected to see so staunch an old sailor as my former topmate. It was not lack of funds, as I had at first imagined, but simply a caprice of the old fellow, who had been a whaleman in his early youth, and had now a notion to refresh his memo. ries of auld lang syne by another cruise.

"Besides," said he, "you know I can never make anything in a merchantman, and the Service is too strict for me; so I think whaling is perhaps my best refuge. It's a lazy sort of life, and if one chooses aright, he need suffer from very little except the inevitable blubber."

Poor fellow, he was now growing old, and his gray hairs and rheumatism warned him to choose for himself an easy berth. So he had come down to "Bedford" with the hope of securing a place in some sperm whaler, as boatsteerer.

His arrival was a most fortunate circumstance for me, as he was able to post me up in all the mysteries of shipping, as well as give me much necessary advice concerning the kind of voyago I ought to make choice of. Bill and I spent the day very agreeably together, and parted at 
evening, with the determination to go in une ship if possible.

The presence of an old shipmate made my stay in New Bedford much pleasanter than it would otherwise have been. He introduced me to au outfitter who had promised to get him a ship, and who readily engaged, for a consideration, to perform the same office for me. He informed us, however, that there was not the slightest hope that we two would be able to go in the same vessel; "for," said he, "no ship owner in Bedford would be so silly as to take two such old salts as you in his vessel."

And here I may as well explain what is the particular office of the outfitters, in a whaling port. The seventy-five dollars advance, or outfit, which is supposed to be given to each individual whe sails before the mast in a whaleship, is dividea among three persons: First, the shipper, whose bill is for forwarding to New Bedford, and his price for obtaining the new recruit a vessel; next, the boarding house keeper, for boarding and lodging during his stay in town; and thirdly tne outfitter, for a complete stock of sea clothes, sufficient, were they of excellent quality (which they not unfrequently are), to last a careful man two years. In a place where so large a number of men are sent to sea annually, the business of fitting these out for their new life is, of course, cne of considerable importance. The outfitters 
give employment to a large part of the laboring community, in preparing the articles which thoy find most necessary to whalemen, and in turn pockot no small share of the earnings of almost every man that sails out of the port. Not only the new beginners do business with these men, but boatsteerers and mates procure their outfits of them, (of course of a superior quality), and they not unfrequently also make considerable advances of money to such individuals as they think trustworthy and sufficiently smart to make a good voyage.

The New Bedford outfitters are faithfully abused by most who have sailed from that port in the capacity of greenhorns, and it is currently believed that their roguery knows no end. But as a class this report of them is far from correct. So far as I ever had any dealings with them, they seemed to be honest enough. But it must be confessed that many of the poor fellows who make their first voyage from here, offer most tempting inducements to traders, to cheat them. Their ignorance is so glaring, and their gullibility so vast, that I fancy it requires a stronger virtue than dealers in ready made clothing are commonly possessed of, to withstand these combined temptations. If, therefore, occasionally, or perhaps oftener than that, a greenhorn is sent to sea, with a rag-fair outfit, and finds his calico trowsers melting away before the salt water, his dog's hair shirts falling 
to piecus, his boots made of brown paper, his hat of the same material, slightly glazed, and his peajacket, "like Jack Straw's house, neither wind. tight nor water-tight," I opine that an impartial wonsideration of all the circumstances in the case would lead him to the opinion that himself was at seast partly in fault.

Old Bill and I enjoyed ourselves finely, for a lew days, during which we visited nearly every ship in the harbor, took several jaunts to Fairhaven, a village directly opposite and across the river from New Bedford, where, also, numbers of fine whaleships are fitted out, and acquainted ourselves with the destination and general character of all the best looking vessels in both ports.

On consideration, I had determined to engage on board a sperm whaler. By doing this I should escape the exposure to cold weather necessarily incident to the pursuit of the right whale, which is found in the higher latitudes, while the cachalot, or sperm whale, is sought for chiefly within the tropics. Moreover, all the right whalers at that time fitting out, were bound around Cape Horn, and thither I had already been. I finally settled on the Indian Ocean, and the Japan cruising ground, as the places I should most like to risit in a whaleship, and determined to look out for an opportunity to go in that direction.

But although the work of fitting out vessels was going on unusually briskly, it seemed to me 
that "chances to ship" were, as yet, few and far between. Occasionally, when we could learn that a captain or owner was about to ship hands, Bill and I would present ourselves with the crowd, and wait patiently to be chosen or left, as his high mightiness should see fit; and I must own that to be left was invariably our fate.

We rather enjoyed our stay, nevertheless, as we found much to amuse us, particularly in watching the maneuvers of the new hands. The salt air seems to have the effect of increasing their bumps of credulity to an almost incredible size, and they "hoist in", without difficulty, stories of whales, or of sea life and adventure, which would hardly do even to tell to the "marines," those old time receptacles for all that requires an unusual amount of faith in the believer.

Most astonishing yarns of the freaks of whales were daily spun to admiring circles of the verdant ones, by mischievous boatsteerers, who became afterward, in the eyes of their unsophisticated listeners, wrapped about with such a halo of glory as is commonly awarded to none but the greatest heroes. Moreover, the most laughable tricks were continually played off upon the ignorance of the new-comers. "Johnny-come-lately," is the butt for everybody's practical jokes, and sometimes has his unlimited confidence in human nature severely shaken, by the conduct of his pre. tended friends. 
Boarding a vessel on the Fairhaven side of the river one day, Bill and I were surprised to see upon the newly painted door of one of the cabin state-rooms, the words "Hezekiah Ellsprett' berth," written in tolerably conspicuous letters, with chalk. The following day the joke leaked out. It is usual, when a crew has becn shipped, for them to hurry on board their vessel, and make choice of their sleeping berths, the earliest comers securing of course the most desirable places.

It appeared that Hezekiah had gone on board his ship for the purpose of making choice of a berth, and after a deliberate scrutiny of the premises, fore and aft, had arrived at the sage conclusion, that a certain state-room contained more of the elements of comfort, than any other place which had met his eye. He therefore determined, after weighing all chances, that he would make choice of this room, as his.

It is but justice to say that a faint glimmer of doubt as to the tenableness of his position did invade his cranium; but on making inquiry of the ship-keeper, that worthy assured him that he had an indisputable right to choose whatever berth suited him best-and advised him for further security to write his name upon the door, and place his bedding in the bunk or standing bed-place--. which he immediately did.

One can imagine the Captain's surprise, on coming on board next day, to find himsolf a trespasser 
in his own domain. But words would fail to describe the unaffected look of astonishmont displayed in Hezekiah's sapient countenance, when he was informed that that was " not his end of the ship."

The tricks were not all played upon the new comers, however, as the manner in which my old friend Bill, shipped, sufficiently evinced. I had been in town nearly two weeks, when my worthy ship-mate met me one morning, and informed me that there was a chance that day, of which he intended to avail himself. A little barque, fitted for a short cruise in the South Atlantic, was about to ship hands, and in her, Bill had determined to secure a berth. Accordingly at ten o'clock A. M., the hour previously specified, a large number of "hands" betook themselves to the office of the owner, located on one of the wharves. Here, at one end of a large room, on a raised platform, sat a portly, cross-looking gentleman, whose selfsatisfied and important air sufficiently proclaimed that he was full well aware of the power he was that day to exercise, as well as of the importance of bringing all his perceptive faculties to bear upun the matter in. hand, in order that he might make a fortunate selection of men. There was that in the gentleman's eye which told plain as eye can tell, that he was not on this occasion to be taken in.

Up to this worthy's chair of state my poor friend was ushered, hy the shipping-master, whe 
had determined to secure him a berth that dayby hook or crook.

"Is this the man you mentioned to me, Mr Jones?" asked the owner.

"Yes sir, and a most excellent fellow you'll find

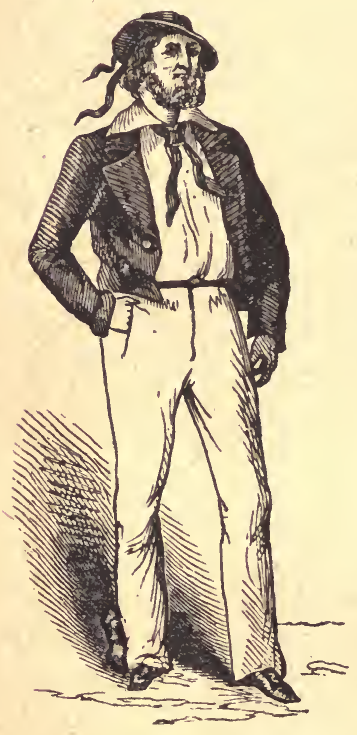
him, sir-a good whale man and a quiet fellow."

"Please go out my man please go out-you are too old a salt for me; 1 would'nt allow you to pay your passage in a vessel of mine," was the owner's answer, after closely scrutinizing poor Bill for the space of two or three minutes.

"Mr. Jones, I'm astor. ished that you can think of offering me such a man -why he's a regular merchant sailor, if my eye knows anything concerning the bearings of those vagabond fellows."

Mr. Jones looked crestfallen; seeing which, the ownor added, "I promised to ship one of your men, and will keep a place vacant for one if you van bring me down somebody that will suit."

A bright flash 'from. Mr. Jones' eyes would have told a close observer that a fortunate idea had in part relieved him of his embarrassment. With 
nimble steps he hurried from the hall, and overtaking Bill and myself, on our way to the office, whispered something in the former's ear.

"By the great hook-block, I'll do it," said Bill, after a moment's consideration, and catching my arm he rushed into a barber. shop, closely followed by the shipper.

"Take off my whiskers as quick as you can, Yankee John," said Bill to the Portuguese barber, while Mr. Jones added "and a good portion of his hair too, my man." In a very few minutes Bill's face was denuded of an enormous pair of whiskers, his long flowing locks were trimmed closely all round, and looking in the glass he swore he hardly knew himsolf.

"Now come up to the store."



Arrived there, Mr. Jones produced a pair of pan. taloons of yellow and light blue crossbarred stuff, a shirt which had evidently already been is contact with whale oil, and one of those abomin able hats, whish, as Bill said, "would make osd Jimmy Square-foot himself look like a grest horn." 
After donning this suit, I was myself, almost tempted to doubt the identity of my shipmate.

All the gay, careless swagger of the sailor was gone, and he looked as much like a veritable clodhopper, as though this had been his first introduction to salt water.

"Come along now-no time to lose," said Mr. Jones-and he and Bill hurried off to make an. other attempt upon the wide-awake owner; I remaining at the store, for fear of compromising by my presence, the success of Bill's plans.

Arrived at the office, they found nearly all the former crowd gone-and the owner sitting upon the platform, complacently looking over some accounts.

"Ah, Mr. Jones, this is your man, I presume?"

"Yes, sir-I think you'll like him better."

"He has not been at sea at all, I fear, Mr. Jones, and we wanted some one that would be of a little help."

"He has made a short trip in a Provincetown whaling schooner, and I think captain Mayhew will find him a handy fellow-although to be sure he looks rather green."

"How long were you out my man?"

"Six months; sir."

"Do you drink?"

"No sir."

"Do you think you could strike a whale?

"Yes sir, if they will give me a chance."

"That's the talk; chance 5 Ju shall have. I'll 
shir Jou-give you a seaman's lay, and if there is a vacancy among the boatsteerers during the cruise, you shall have it, provided you are smart."

Expressing himself highly satisfied with this, Bili signed his name to the articles-as Ezekiel Nickersor-and hastened from the presence of the shipper, who felt highly elated at securing so elig. ible an individual-little thinking that scarce half an hour before he had sent him from his office. Said Bill when he came back "so good a joke as that ought to be washed down with some brandy" - and accordingly he got tipsy in honor of the event. 


\section{CHAPTER III.}

Tre Sag Harbor Whaleman-Shipped at Last-Arrangement of a Whaleship's Decks-The Try Works-The Boats-The Lower Deck-Sailing Day-Our Crew-Sea-Sickness-Training the Greenhorns-Labors of an Outward Bound Whale. man-Drudgery.

IT was on the third day after the shipment of my old friend, that my turn at length came. I had begun to despair of getting a ship-not hav. ing the resources at my command by which my friend had circumvented the owner; but the ship. pers desired me to wait some few days longer, as a chance would soon turn up. Accordingly, one morning I was desired to step down on board a Sag Harbor ship, which had just come up for the purpose of engaging a crew, and completing her outfit.

I was the bearer of a note to the captain; who, having read it, looked at me a few moments, and then asked:

"Have you ever been whaling?"

"No sir."

"How long have you been at sea?"

I mentioned the number of years.

"Do you intend to run away at the first port we make?" 
I answered that such was not my intention at that time.

"Well," said he, finally, "I think I'll ship you; I can give you the one hundred and twenty. Gifth lay, whic: is a better lay than we generally givo men, and if you behave yourself I'll take care that you are advanced as fast as you yourself car. desire."

Having declared my readiness to "sign the articles" there and then, we stepped into the cabin, where the contract was ratified, and I engaged to go upon a voyage "to the Indian Ocean, and such other seas and oceans as the captain might see fit to visit, in pursuit of his business of taking whales," etc., etc.; the voyage to be not completed until the return of the ship to a regular port of discharge in the United States.

Whalemen do not work for wages-but for a proportionate share in the proceeds of the common voyage. This share is called each man's lay, and varies greatly, according as a hand is more or less active and experienced. Thus, while my lay was the one hundred and twenty-fifth, (meaning that my share in the gross proceeds of the voyage was at the rate of one barrel in every one hundred and twenty-five), the lay of the green hands ranged from the one hundred and eighty. fifth to the two hundredth, giving them only at the rate of one barrel for every one hundred and eighty-five or two hundred. Boatsteerers, mates, and even captains, sail "on a lay;" receiving, as a 
matter of course, shares proportionate to their experience and the importance of their duties.

Having signed the articles, I received a note from the captain to the shipper, to that effect, and w s informed that the ship would sail on the next day but one, and that it was desirable I should render myself and luggage on board on the evening previous.

The first matter which claimed my attentior after returning to the shore, was the procuring of an outfit of clothing and other necessaries for the voyage. As before mentioned, on shipping in a whaler each man receives credit from the owners, for an amount sufficient to provide him with a certain necessary quantity of clothing, and to pay the bills for board and shipper's charges, which he has contracted while waiting for the vessel. Of clothing I needed but little, as $\mathrm{my}$ chest was well supplied. I took, however, a plen. tiful supply of blue dungaree (cotton drilling) of which I designed to make up my own clothes for warn: weather, when we should have gotten to sea. A number of pounds of chewing tobacco and half a bolt of coarse calico, to trade among the natives, completed the items on my outfitter's $\imath$ ll.

'This and other bills rendered, and signed by ine, I betook myself on board, with chest and hammock, determined, as our voyage was to be a long one, to secure as good a berth as possible in the forecastle. This I succazded in doing, being, 
with the exception of two men who had come in the vessel from Sag Harbor, the first on board.

The forecastle was a large, roomy place, displaying the usual two tiers of berths on each side, and a locker at the bow, where could be stowed pots, pans, spoons, and other table utensils. The floor was encumbered with cleats, used by those who had last occupied the place, to fasten their 1:hests. There was a disagreeable smell of train oil, and other sea abominations, pervading allbut to smells of this kind my olfactories had long been accustomed, and they were therefore of no sonsequence to me.

After securing my berth, and lashing my chest in its place, I proceeded on deck to make a more minute examination of the vessel which was to be my home, in all probability, for some years. The decks of a whaleship are fitted up in a manner greatly different from those of a merchant vessel. Amidships, where the merchantman stows his longboat and spare spars, are the try-works-a frame built up of brick, with two, and sometimes three, large iron pots placed in the middle, beneath which is the furnace or fireplace. Stout iron knees, bolted to the deck, keep this mass of brick and mortar in its place. Over all is a large wooden cover to keep out the rain.

The deck is sheathed fore and aft with thin pine lumber, to save the main planks from injury which mast otherwise be done them, by the cutting and hacking of blubber, and the rolling of 
oil casks, incident to trying out and stowing down a whale. A portion of the starboard side, the waist, as it is technically called, is also thickly sheathed, as it is here that the blubber is taken in from the whale along side. The bulwark, or rail, at this portion of the side is moveable, and can be taken out entirely, which is done when "cutting in."

On the starboard side a whaleship carries but one boat-the cranes for which are hung upon the quarter. As ours was a four boat ship, we had the remaining three upon the larboard side, sccupying a space there from the quarter to the forerigging. It is a matter of much difficulty, at sea, while a vessel is under sail, to lower a stern boat, for which reason whalemen never carry a boat on stern-davits, as merchant vessels are accustomed to do.

Two spare boats, stowed overhead, between the main and mizzen masts, and thus making a good shelter on the quarter deck during rainy weather, completed the fitting of the decks.

Aloft our ship differed but little frorn most other vessels of her size-the little top-gallant-crossurees, the stations for look-out men, being the only peculiarity which would bespeak her business to a sailor.

The lower deck was divided off into : forecastle, where the crew live; forehold, a place where all spare rigging, hawsers, and cutting-in gear are stowed, as also spare lumber for repairing boats, 
and a large assortment of spare oars, any vacant space left being filled with oil casks; the blubber room, a large space, just below the main hatchway, into which the blanket pieces, just taken from the whale, are lowered, there to be cut up by the blubber-room men, into horse pieces; and lastly, the steerage-where the boatsteerers and cooper have their place of abode.

The hold is filled with oil casks, most of the lower tier of which are at the commencement of the cruise filled with water, while in the upper tier are contained the bread, beef and provisions, as well as sails, dry goods for trade with the natives, and all ships stores whatever, everything being stowed away in casks to economise space, and get on board as many of the latter as possible. A forty gallon cask of Epsom salts-medicine for the sailors - figured conspicuously among the stores.

It was on a fine morning in June, that we sailed. The crew had been all gathered on board the preceding afternoon, and the vessel hauled into the lower bay, ready for a fair start; and now having bidden good-by to all friends and acquaintances, we weighed anchor and set sail, taking a last, and I nust confess, with me rather sorrowful look at the beauteous verdant shores of America, which we were now leaving for an absence of not less nan three, and perhaps over four years. I was einbarking on a voyage with the nature and duties of which I was but slightly acquainted, and although bound for a part of the world which I had 
not before visited, and animat w with all of a sailor's happy carelessness and desire for novelty, the thought that I had engaged myself for so long a time, troubled me. But "sufficient for t'se day is the evil thereof," is a maxim upon which the sailor, more than perhaps any one else, acts, throughout life, and in accordance therewith, I drove away the clouds gathering over my thoughts as I contemplated the blue hills, every moment growing paler in the distance, and enjoyed the glorious sunshine, and fresh, pure breeze of one of the finest days in summer.

Our crew, now that one could see them all together, formed a motley set. A four boat ship carries generally twenty-three or twenty-four hands, in the forecastle, a cooper, cook, four boatsteerers, ship-keeper, steward three mates and captain; making in all thirty-six men. The captain, two mates, and three of the boatsteerers were Americans. The third mate, and one of the boatsteerers were Portuguese, natives of Fayal, as were also four of our crew. A great many of these Western Island Portuguese are found in American whaleships, where they are much liked, being very quiet, sober men, and generally good wnalemen. The rest of the crew I find enumerated in my log, as follows: two lawyer's clerks; one professional gambler, one runaway from his father's counting house in New York, (this was also ac amateur gambler), one New York " butcherboy"-his name was Mose--six factory hands, from 
sorresmall New England towns, one Boston school boy, one canal-boat man, six farm boys-from various parts of New England, and western New York,--the four Portuguese before mentioned, who were whalemen, and the writer hereof, who wroto himself seaman.

Of the four professional men, as they caller themselves, all, including the gambler, were the possessors of a tolerable education, and a fair share of general information. As for the rest, leaving out the school boy, who knew everything, and was therefore unbearable, they were as wretchedly ignorant a set as ever I met. But one of the factory hands could read, with any degree of ease, and he was if anything, more stupid than his fellow laborers. As for the farmer boys-they possessed the latent elements of smartness, but were unfortunately so largely endued with cre. dulity as to be the victims of never-failing pra3tical jokes.

We sailed with a fine and favoring top-gallant breeze, and long before night were well clear of the land, and making a straight wake for Fayal, which, to the great joy of our Portuguese shijs. mates, was to be our first port. As the sun sank holuw the horizon, the breeze freshened and the well increased, so that by the time the first watch commenced, at eight o'clock, the top-gallant sails were taken in-by the few hands who had been at sea before-the green hands wisely declining tc 
hazard so dangerous an undırtaking as "going aloft in the dark."

"Your time will come soon m.nonly wait, my lads," said the mate.

During the night we had what would have been for a merchant vessel a stiff top-gallan breeze. We were, however, reefed down, as $\varepsilon$ matter of prudence, not knowing how hard it might come on to blow, and having but few hands to depend upon. The green hands were upon their beam ends in all the horrors of seasickress, alternately vomiting, and praying for deliverance from what they imagined to be a most unprecedented gale. All their bright anticipations of the pleasures of a sailor's life were vanished, and they wished for nothing so much as "home."

But the night came to an end. as all nights muss do, and the sun rising bright and glorious from the sea, scattered the storm-clouds, and made our verdant friends more cheerful. Wan and disspirited they came upon deck, and laid themselves down in the cheering sun, looking and feeling as though just recovered from a severe illness.

It is notorious that seasickness is a weakness for which, as no one was ever known to die of it, no non-sufferer feels aught but contempt. Little of the pity and kindness, therefore, which they felt to be their due, did our sick men receive. A gruff "get out of the way, greeny," from the mate. as he stumbled over a form prostrate in the gane. 
way--or a threat to send some of them alctis "with a rope's end after them, to expeditc them on their passage," made their misery zomplete.

As the wind died avray however, and the sea calmed down, they recovered to some extent, and made the best of their way down below again, where they almost without exception kept their berths for a couple of days, declaring that even to look up at the masts swinging about, with the motion of the ship, made them dizzy and deathly sick.

"As for getting up there," said one, pointing to the masthead, and speaking with great earnestness, "that is entirely out of the question; I am not fool enough to try it."

With what dismay, therefore, did they hear, on the third day out, the word passed below, for all the green hands to come on deck, to practice running up the rigging. With doleful groans, and dolorous countenances they most solemnly asserted the utter impossibility of such an undertaking on their part, and the certainty of their falling before they got six feet above deck.

"There's no such word as can't, at sea," was the mate's reply, as he apportioned them, a certain number to take each rigging, and then, mak.ng some show of a stout rope's end, ordered them to start.

"How far up must we go?" asked one with great 'nterest, eridently with the intention of purting 
off the evil hour, if only for a minute more, by asking questions.

"Go ahead, I'll tell you when to stop."

Paler than so many ghosts, they mount the rigging, now taking a step, then taking the shrouds in their close embrace, now glancing aloft, or around with looks of terror and dismay, anon looking piteously down at the mate, who, hardhearted fellow, answers them with a "now then, are you fellows going to stick there?"

"I'm afraid I shan't, sir," answered one, giving vent to a joke in his desperation. But a boatsteerer in each rigging, with a rope's end, soon started them on their upward journey, and having gotten up as high as the top, they were allowed to come down, a proceeding about which they went as circumspectly as though on every step depended a life. Great was their relief when they once more found themselves on deck.

After a week of such practice, the greater portion of the crew were able to take their turn at the masthead to look out, doing but little good there however, as they were not yet fairly recovered from their sickness.

Three of our country boys remained seasick, antil by dint of neither eating nor taking exercise, they were too weak any longer to come upon deck. They spent the days in watching the motions of the vessel, and the nights in groaning an : bewailing their hard fate-continually wishing themselves back to the homes they had 
THE CAPTA IN IS ASKED FOR PIE 51

so gladly quitted. To one of these came one evening a boatsteerer, and after condoling with him upon his miserable condition, asked him what he though ', he would like best to eat just then.

"The sight and smell of the food they have or the ship make me sick," was the answer. "If I only had some nice milk, and some pie, such as my mother used to make, I should be well very soon."

"Pie!" exclaimed the boatsteerer, "as I live, I am glad you mentioned the word. There's a whole cask of pies down below, which was sent aboard by the owner, on purpose for the sick ones."

"Suppose I were to ask the captain to hoist it up, and give me some?" suggested the sick man, eagerly.

"You could not do a better thing."

"I'll go to him immediately-he seems to be a kind man and I will tell him how badly I feel." Accordingly he dragged himself slowly aft, and there meeting the captain, stated the case to him, and ended with a request that some of the pie might be given him, as he felt convinced that he would soon recover on such diet.

The captain, smiling grimly, expla:ned to hime that some unfeeling wretch had boen trifling with him, and that pie wae an impossibilty at soa.

Heartsick, poor Joe returned to his bunk; but at dinner, the cook brought him a small pie from 
the captain's table, that worthy having taken pity on the poor fellow's deranged stomach and simple mind.

Multitudes of such practical jokes are played off upon the uninitiated, and many a hearty laush at their expense enlivens the first part of a whale. ship's eruise. Their faith is boundless, and ther is scarcely anything too absurd or impossible for some of the more ignorant. Singularly enough, the young man who asked the captain to broacs: a cask of pies for his benefit, subsequently berame one of the smartest of our hands.

There is nothing the inexperienced on board find it so difficult to grow aceustomed to as the differ. ence in rank, and consequent difference in physical comforts, which prevail on ship board. Why the captain and his three mates should have nore space allotted to them, than twenty sailrors, or foremast hands; or upon what principle of right or justice the officers shall dine upon delicacies, while foremast Jack soaks his hard biscuit in a lecoction of oak leaves, sweetened with molasses, which goes by the name of tea; or how, under a republican flag, the captain can order them off the quarter deck, the pleasantest portion of the $\nabla c$ ssel, and point to the wretched hole forward of the windlass, as their appropriate "sphere"-all this, and much else, the unsophisticated countryman, brought up in the belief that "one man is as good as another," can never properly understand, altrough he is obliged to submit. 
As one of our "professional me.l" said one day, in arguing upon the justice of such conduct-"It is not Democratic."

But to submit-to obey orders, instantly and unthinkingly -is one of the first principles inculcated into the embryo sailor, here as well as in other classes of ressels. It is the great secret of success in all maneuvers at sea, and perfection in the training it imparts is especially necessary on a whaling cruise, where, in sudden emergeneies, it is often required that the mind of one man should have perfect control over the will and strength of many.

Meantime the training went on : the daily prac. tice of running aloft, speedily making even those who were at first most timid, laugh at their former fears. But now another difficulty was to be gotten over: The names of the various portions of the rigging were to be learned. This seemed one of the most insurmountable obstacles to the acquisi . tion of sailorship.

Landsmen persistently adhere to a literal interpretation of the naines given to various parts of a ship's rigging and masts. Thus by top they understand the mast head, whereas it is a place not half so high. They look for a head, and find only a few rough boards; they are told of stays and see only great ropes; they hear of yards but find them pendant from aloft, "like the inanging garder. of Semiramis," said our school-boy. 
It must not be supposed, however, that to famil iarize themselves with the ropes and practice running aloft were the only employments of the hands. On the second day after leaving port, the regular routine of labor of an outward bound whaleman was begun. All hands were kept at work, hard and incessantly, for the first five months, preparing the vessel for the whaling ground. It is a rule in the whaling service to have no work of any kind, other than is absolutely necessary, going on while the vessel is upon the whaling ground. All is therefore prepared beforehand, on the outward passage.

With us the entire rigging was overhauled and refitted; the hold in part restowed; boats fitted with all the conveniences which experience has taught the whaleman to provide; irons and lances sharpened and set in their handles, lines stretched and coiled down; line tubs nicely fitted; lance and iron sheaths carved or put together, mats for rowlocks made, and all the thousand other small matters attended to, which go to make up the outfit of a whaleship and her boats. These labors employed the crew from daylight till dark, six days in the week, and right glad were we when the tall Peak of Pico hove in sight, and amid the excitement of nearing the land, the severe and constant drudgery of refitting was for a few days laid aside.

By this time-we had a three weeks passage thither-our green hands were, in their own estima- 
tiou grown to be staunch and fearless sailors: they could swear horribly; they chewed tobacco, to a man; they talked loudly of their powers to with stand the effects 'f liquor - to have listened to them, one would have thought each one of them had been bred and born in a grog-shop. They could, to be sure, tell no tough yarns of their past experience, but they made up abundantly for this by their boastings of what they contemplated in the future. In short, they were all-with two honorable exceptiors-a most disgusting set; who thought that in coming on board ship, as they relieved themselves in a great measure from the restraints of civilized life, they were warranted in launching out into every vice that brutalizes man. 


\section{CHAPTER IV}

Land Ho!--Fayal-Anxiety of all hands to get askure-Pyr tuguese-Their resignation-Fruit-We continue the roy age-Fitting the vessel for her cruise-Drilling the crew in the boats-The line-Chasing Blackfish-ProvisionsCooks.

AT length the summits of the Azores heaved out of the water, in the blue distance. Land ho! was a cry joyful to ail, but particularly to those who were now making their first trip. I do not know of a more pleasing sensation than that which animates one on for the first time beholding a strange coast-supposing that coast to be invested with some interest in the mind of the beholder, and that it is seen in fine weather. Both these conditions were fulfilled in the present case.

Our Portuguese shipmates had for the past week spoken of scarcely anything else but Fayal, the Peak of Pico, and the various islands which compose the group called the Azores; praising above all, the fruitfulness of the soil, the genial climate, and the quiet innocence of the people. Tho weather was lovely, and as the blue summit of Pico showed itself ir the hazy distance, while a light breeze rippled over the smooth sea and urged our vessel landward, all were for a while 
subdued, and entered heart and spirit into the peaceful s?ene.

It was midday when we raised the and. On "turning out" next morning, we found our ship lying becalmed in front of the vast Peak of Pico, which, at a distance of some ten or twelve miles, seomed almost overhanging the vessel. All was now bustle and preparation. The Portuguese, usually so taciturn, were excited beyond all measure; and as under the pressure of a gentle breeze we neared the land, they eagerly pointed out to each other, and to the crew, various objects, familiar to them, the scenes of former labors or pleasures.

And when at last, about four o'clock in the afternoon, we dropped anchor in the bay, the Portuguese boatmen who shortly came on board, were hailed and shaken hands with as old familiar friends, although they had probably never before been known to our men.

It is a very agreeable thing to make land, under almost any circumstances. The tedious and monotonous life of a sea-voyage is pleasantly broken in upon-and aside from the satisfaction felt by all on board at knowing that so much of the object of the voyage has been accomplished, every mind revels, in anticipation, in tho pleasures and diversions of the shore. On such occasions old quarrels are amicably arranged, and new friendships are formed; all hearts open urconsciously: and while gazing with eager longing at the blue mountain tops in the distance, you suddenly ar 
rive at the conclusior that the individual standing beside you is a first rate fellow-all previous prejudices to the contrary notwithstanding.

Of course, our crew hoped to have a run on wore. I never sailed into a port in my life, that the crew, or a portion of them, at any rate, had not prepared their minds for a day's liberty. How often and bitterly have I myself been deceived and disappointed! This time, however, I knew better than to expect "liberty" for any one. We had no oil to land, nor, in fact, any business in port, except to procure some ten or fifteen thousand oranges, and a quantity of other fruit, with a few sweet potatoes. We should not have anchored at all, had it not been that the captain had a relative on shore, with whom he desired to spend an evening in quiet, and without anxiety.

Bitter lamentations at their hard fate succeeded the announcement to the green hands, of the im. possibility of their getting on shore; they could scarcely believe that the captain could refuse them such a favor; and that night sundry schemes were laid for running off from the vessel, and thus gratifying their wishes without the consent of the captain, whom they regarded as a cruel monster. These were, however, the veriest air castles, which crumbled from view at the slightest touch of practical common sense.

"Súppose you greenhorns run away-what will you do when you get ashore - you are no sailors -no captain would ship you. You can't get work 
ashore, for the poor people can't get bread for all that are already on the island"-was the discouraging remark of a boatsteerer who had been taken into their confidence; and so the idea of running qway was abandoned.

As for myself-I had long since become hald. ened to such disappointments, and although just as eager to have a run ashore as any one, was able to philosophize on the disappointment of our hopes. I think the life of a man before the mast is calculated to make a stoic of any one. In no other condition that I know of, are all the hopes, aims and desires of one man placed so completely in the keeping of another-whose interests furthermore almost invariably clash with those of his subject. No where else are the keenest desires so invariably doomed to disappointment-in no other situation is one obliged, for peace of mind sake, to become so utterly apathetic. The fact is, sailors should be brutes-not men.

By our poor Portuguese the compulsory stay on board was doubtless more keenly felt than by any others. It was their fatherland-and to their uredit I must say that I found them invariably to cherish a strong love for it, poor and rude though it may be. But after the first excitement of seeing and speaking to the people in the shore-boats; was over, they settled down into a calm, desponding sort of enjoyment, and in the dog watch gathered into a little knot upon the top-gallant forecastle, and gazing upon the loved shore, talked of horne, 
of the happy days they had there enjoyed, and of their present prospects, and hopes of some day being able to settle down in comfort there, with the fruits of their hard labors.

A great many Western Island Portuguese find umployment in American whalemen; almost every vessel sailing from New Bedford carrying more or less of them. They are a quiet, peaceful, in sffensive people, sober and industrious, penurious, almost to a fault, and I believe, invariably excellent whalemen. They are held in great esteem by ship owners and captains, but are often despised by their shipmates in the forecastle, who seeing them of such different habits to their own, choose to decry them as sneaks, and tale-bearers.

I found them quite the reverse; and with one or two exceptions, those with us were the only individuals of the crew with whom I could associate with any degree of pleasure. Brought up in the most abject poverty, it is natural that they should be saving-and refuse to waste their hard earned money for trifles or in dissipation, as is the fashion with sailors in general.

They have moreover an object in life, which is never lost sight of in all their wanderings and toils It is their hope some day to be able to settle down on their native islands, among their friends and ki tdred, and with the savings of years of hard labor, to spend their latter years in peace. ful retirement. Very many, I have been inform. ed, have lived to realize this day-dream, and 
jaking the few hundreds of dollars, which is the sum of thoir savings, have returned to live at ease in the hoine of their youth. It is not possible that men who cherish such recollections, and en. ter on life with such hopes and determinations, should fall to the depths of depravity and vice in which whalemen generally lose themselves.

Early on the morning succeeding our arrival in port, several large boatloads of fruit, with some potatoes, and half a dozen razor-backed pigs were brought along side and taken on board. Immediately thereafter we once more got under weigh, and departed on our long voyage. When the anchor was stowed and all snug for sea, the oranges which had been brought on board were divided among the crew, each one receiving a share to take care of, and eat as he saw fit. This is the usual nianner of proceeding in such cases, on board a whaleship, and prevents all after quarrels, inasmuch as each one can make as much of his hoard as he pleases.

My share amounted to nearly three hundred. They lasted three weeks, and it was with an anxious desire for more that I put the last and juciest one to my lips-well knowing that many montkg would, in all probability, elapse before we should be favored with another run into port.

Once more at sea, the old wearisome drudgery recommenced. Here a patch and there a mat, in one place a new rope, in another an old oriv refit. :ed, tarring and slushing, scraping and scrubbing 
day after day proceeded the labor of fitting the ressel's rigging, sails and deck for the endurance of a long season of neglect. Meanwhile we were keeping a stricter lookout for whales, hopeful that we might at this early part of our cruise fall in with and capture some "good fish."

All the crew were now to some degree broken in to the sealife, and pretty soon the new hands began to claim for themselves great credit on the score of seamanship. With infinite pains they had been taught a few of the many splices, knots, and ties which all old tars have at their fingers' ends. With doleful groans they had practiced running aloft, until the first emotions of fear and dizziness had worn off. By dint of steady perseverance they were now able to chew tobaceo without being nauseated, and to spit about the decks without feeling that they were committing a dirty trick. As for swearing, I must own that that accomplishment they seemed to master without any apparent effort. They could hitch up their suspenderless trowsers, and cock their hats on "three hairs," in a manner faintly resembling that supposed to be peculiar to the genuine tar: and so they called themselves sailors. They had arrived at the summit of their tree of knowledge, and did not fail to congratulate themselves upon the prospect stretching out before them.

Alas! they had one more mortification to undergo-one more difficulty to overcome,-yet an. other branch of the business to familiarize them 
selves with, before they would be even whalemen -and what old salt does not know that there is as much difference between a whaleman and a true sailor, as there is between a child's tin truntpet and the bugle which calls to battle.

'To tell the truth, I, in virtue of being a real, genuine tar, despised these fellows from the bottom of my heart; and it must be owned, they hated me with a fervor which was only equaled by its powerlessness.

But to return to my story. We were three days out from Fayal, and had by the aid of a farorable breeze, left the lofty Peak of Pico many miles behind us, when coming upon deck one morning, we found a dead calm, a tolerably smooth sea, and a thin hazy atmosphere, which, to the old whalemen aft, looked like whaling ground. Shortly after breakfast word was passed to man the boats, to take some practice in pulling and maneuvering, in order that our crew might not be entirely unprepared, should we be so fortunate as to fall in with whales.

The various boats-crews had been chosen when we were but a few days out at sea, and each indi. vidual had received some general instructions as to his particular duties.

And here it will be as well to initiate the reader into the manner in which a boat's crew is divided, and what is each one's duty. Each boat is manned by six hands in all; of these the officer or boat-header as he is styled, and the boatsteerer, or harpooneers- 
man are two. The four men at the cars are callod beginning at the bow, the bow-oarsman, milshiprarsman, tub-oarsman, and stroke-oarsman.

It ${ }^{\circ}$ s the duty of the first named, aside frcm his labor at theoar, to assist the boat-header in getting cut his lances, when about to kill the whale. He takes them out of their beckets, takes off and stows away the sheaths which envelope the lance-heads, and when hauling on the whale to lance, his particular office is to hold the line at special places on the bow, to keep the boat in a convenient situation to reach the whale. As being nearest to the scer e of operations, and the boat-header's right hand nıan, the bow-oarsman's place is considered one of spec. ial honor, and he is first on the list for promotion

The midship-oarsman is chosen with especial regard to his length of limb and stoutness of mus cle, as he wields the longest and toughest oar in the boat. The tub-oarsman throws water upon the line when the whale is sounding rapidly, tc prevent it from igniting from the violent friction; while the man at the stroke oar, as the name denotes, gives stroke to the rest in pulling, and is also of material se:vice to the boat-steerer in keeping clear the line, and coiling it down as it is haul. od in.

The names of the officers are scarcely expres. sive, at least to a landsman, of their duties. Tho two most important operations, and those requir-. ing most skill in their execution, in capturing a whale, are those of "going on to him" to harpoon, 
and killing him, when once fast. Of course the boat-header takes the most responsible positions in these maneuvers; and consequently he steers the boat till the whale is harpooned-which office is performed by the boat-steerer. Immediately thereafter the two change places, the boat-header taking charge of the bow, to give the whale the death blow.

It is a very unfrequent occurrence, to kill a whale at the first blow, with the harpoon. Whales are so easily "gallied" or frightened, that it is considered an object to get a harpoon solidly fastened in almost any place, the lance being always counted on to deal out death to him.

I may add here that I had been chosen bow. oarsman for the chief mate's boat, an honor whereat I was not a little elated, the more particularly as t had never before made a whaling cruise, and was therefore entirely inexperienced.

Well, we lowered the boats. All was of course, bustle and confusion. Many of the crew had never in their lives been in a boat; and those who had, evidently viewed the long, narrow, shallow, and slender boats used for whaling, as exceedingly suspi cious contrivances, very little to be depended upon

It being a calm day, the crews were directed to "follow the boat down" - that is to say, to slide down by the side of the vessel, abreast of their respective boats, in readiness to jump in as soon ws the roats touched the water. In endeavoring w. jump into his boat-the ship just at that mo- 
ment giving an unexpected lurch-one of our awk. ward siquad dropped into the water, coming up puffing and blowing, some distance astern, to the intense amusement of all lookers on.

But this was only the beginning of the day's sport. Although the sea wore a smooth surface, there was sufficient of a ground swell to make the use of oars, a matter of some difficulty to those who for the first time held them in their hauds. Having gotten the four boats in a line, the mate proposed a race; and at the word, we started. Racing, however, was soon found to be out of the question. The first thing to be taught the greenhands, was to keep stroke-to place their oars in the water all at the same time, and lift them out again with one motion.

The necessity for this being perfectly understood, we tried again. But.now our fellows began to "catch crabs." As the swell would lift the boat, those not paying strict attention would fail to reach the water with the blades of their oars; and not meeting with the resistance upon which they had counted, would incontinently tumble over on their backs, heels high in mid-air, heads under the seats, and oars dangling about pretty much at random. However, after a goodly number of mis haps of this kind, all our own boat's crew arrived at a proper understanding of the first principles of pulling, or "rowing," as landsmen would say, and after two or perhaps, unree days irial and practice,we could propel our boat at good 
speed. Eventually my shipmates made most excel. lent oarsmen, and won themselves laurels in several contests of speed with crews much nore experienced than ours.

We were favored with an almost continual suc. cession of fair breezes, till we neared the line, where the customary calms and light winds gave us occasion for a little more working ship than we had until then, been used to. A strict look out was continually kept, but no spouts greeted the wearied eyes of our look-out men.

On the line, however, one Sabbath morning, a school of black-fish passed quite near the vessel, and of course we lowered for them, but few whalemen observing the Sabbath when whales are in question. Black-fish are a small species of whale, tolerably hard to catch, as they have none of the regularity of movement which is characteristic of their huger cousins, the sperm and right whales. They make but little oil when caught-but to a whaleman all is fish that spouts.

The fish were themselves evidently in high spirits, running about in every direction, breaching, making the water fly with their flukes, and acting out all manner of queer antics. None of the caution and silence usually observed on lowering after sperrı whales was therefore necessary, and previously instructed as to the nature of the business we were upon, and that it was to be considered more in the light of sport, than as a serious 
grasp at wealth, we tumbled into the boats, laugh ing and shouting in high glee.

Four hours of hard pulling, now backing, now laying quickly round, and again bending to our oars with all our strength, always within a boat's length or two, but never within dart of the mischierous fish, convinced us that although doubtloss it is high sport to the black-fish, it is anything but fun to those whose bone and sinew is brought in requisition in a fruitless chase of them.

Now the whole school were right ahead of the boats, and it was "pull boys, and we'll strike one this rising." But just before we got within darting distance, when even the iron was already poised in the boatsteerer's hands, ready to "give ii to him," the provoking fellows would toss their heads and disappear from view beneath the water.

Lying still a moment, we would hear a puff immediately behind us, and lo! there they lay, at heads and points, like a lot of overgrown pickled herring, and apparently with no idea of quitting that place for some time.

"Pull starboard-back your port oars!" shouts the mate, in the greatest excitement, as with a few vast sweeps of his steering oar he lays the boat round. With half a dozen vigorous strokes we send the boat right to the spot whence they savo but that moment disappeared. The next we see of them may be at the distance of half a mile, ind off we scour, af er them, each boat's crew 
vager to be îrst at the scene of operations, but all too late, for after sticking their ugly heads out of the water for some time, as though too lazy to float in the usual horizontal position, they are off again.

Four hours of such sport prepared us to enjoy a much more substantial and elegantly prepared repast than awaited us when wearied and disappointed, we returned on board.

And this brings me to the consideration of that portion of life, which I have noticed seems on ship-board to be considered the main and most important part of existence, namely, eating. What to eat, must be a matter of much thought with men who have nothing but the regularly recurring meal times to break the dreary monotony of every day life.

Men long for excitement; and as idlers on shore discuss the news of the day, and settle the destinies of nations after their own ideas of justice and policy-so do ship captains and mates take into serious consideration the fate of certain chickens, ducks, and pigs, and enter into longwinded discussions as to the proper timo and best method of preparing these animals for the table, while forecastle Jack growls at the cook about the ill-prepared bean soup and the raw duff, : he moldy rice, or half-cooked beef which is set before him.

The provisions for the forecastle in a whaleship, differ but very little in kind from those of a man. of-war, yet there is no regular allowance, a suf- 
ficiency to satisfy the appetites of all being at all times furnished. In several matters, however, whaleships are better provided than either the naval or merchant service.

In the first place, as on such long voyages, where, too, the vessel is for many months at a time cruising about at sea, men are very liable to attacks of scurvy, captains and owners take care to have constantly, so long as they can be proczred, a plentiful supply of potatoes-a luxury which is unknown in the navy, and not always found in the merchant service. Again, as everything is tightly stowed away in large, well made casks, provisions of all kinds are much better preserved than on any other voyages. This is particularly the case with the bread or biscuit, which will be found of excellent quality in a whaleship three or four years from home, while in a naval vessel it is often worm-eaten worthless trash when but a few months out.

But if the provisions are good, the cooks are as a general thing execrable-realizing the old proverb, which ascribes a totally opposite origin to the victuals and those who prepare them. Our cook was a negro, whose only virtue was cleanliness. His cooking stove was always bright and polished, and the copper-sheathed floor of his galley served excellently as a mirror, wherein his shining black face was reflected in a hundred different. attitudes and contortions. He changed bis linen much oftener than the captain, and 
devoted more time to the straightening out of nis kinky locks than the veriest city dandy. He was a full bred exquisite, and withal a very Hercules in strength and agility. As a man he Nas respectable-as a cook abominable. His bean soup was an abortion-his rice, a tasteless jelly, and the duff-that potent breeder of heart-burns, indigestion, and dyspepsia, even in the iron bound stomach of a sailor-reached under his hands the very acme of indigestibility.

Happily it is one of the rules peculiar to the culinary department of a whaleship, that whoever will arrange a private meal for himself is allowed space in the oven to cook it. So when matters came to extremes, and even my sea-appetite rebelled at the unsavory morsels brought up in regular course of cookery, I was used to prepare a dinner or a supper for myself, which although not much superior in point of artistic culinary arrangement, was yet digestible. 


\section{CHAP T'ER V}

SАВBATH-Our Captain's whaling experience-Land hol-.Ta: Scene of a battle-Tristan d'Acunha-The story of its settlement-Governor Glass-The internal economy of the settlement-Intercourse with shipping-General appeas ance of the island-A wreck-An exciting race-Madagascar or Malaga?

Desiring to procure a large supply of potatoes for our whaling cruise, the captain had determined to make a day's stay at the Island of Tristan d'Acunha, a place seldom visited except by whale. ships in want of stores, and one which I had long desired to see.

Meantime we were still engaged in refitting the vessel, and had now gotten so far along that we could see the end of our labors. It is customary in the merchant service, even in the worst of ships, to allow the men who have had two watches on deck the preceding night, to rest during the watch from eight to twelve A. м. On board ; ur vessel however, it was an object to get all the work finished up before we got upon whaling ground, and therefore all hands were compolled to work all day-that is, from eight A. M. to six P. M. - in addition to keeping regular watches all 
night. Those who grumbled at this arrangement, rmong whom $I$ was conspicuous, received for consolation the information that once upon the whaling ground, no work whatever, not absolutely necessary, would be required.

After living amid tar, slush and dirt all tho week, Saturday night-when the deeks were washed down, and all work put out of sight-and Sabbath, were seasons of peculiar enjoyment to all, anci. to none more than myself, who then had a little time for reading, from which I was debarred during working days.

Sunday was with us, at this time, a day for general shaving, washing, and serubbing. Salt water is too "hard" to wash in with comfort, and in consideration of our labors during the week, we were on Saturday night indulged in two quarts of fresh water per man, with the aid of which we suceeeded pretty well in removing the stains of the past week.

Mending, too, was in order on the Sabbath. The Portuguese among our crew had been wise enough to ehoose their own outfit. I had needed but little clothing, but had taken some light drilling: instead, to make up for myself shirts and trowsers, an art in which I was by this time quite a proficient. The new hands had taken whatever the outfitters had chosen to say they needed, and some of them had been woefully cheated.

Woollen shirts which, after the first washing, one could pull to pieces-as though made of tow- 
and cotton trowsers which blew apart as they hung in the rigging to dry, such was, with three or four exceptions, the quality of their supply of clothing for a four years cruise. Some there were bowever, who had fallen into better hands, and these had received the worth of their money in good substantial clothing.

Green hands often prefer while yet in port, to deal with the very men who afterward cheat them so outrageously-for the reason that these will, in most cases, advance them small sums of money during their stay on shore, to be charged as clothing in the bill, while the honest dealer ignores all such transactions. Thus the inexperienced and unthinking often for the sake of a little indulgence on shore, sacrifice their comfort during the greater part of a cruise.

It is not expected however, that the clothing obtained of the outfitters shall last the crew the entire cruise. And as clothing stores are not known in the vicinity of many of the whaling grounds, the captains are provided by the owner with a "slop-chest," furnished with all articles which are likely to be wanted for the particular voyage upon which the vessel is bound. These slopchests were in former times the perquisites of the captains, and they often made immense profits upon thoir investments; from two to three hundred per cent being considered only an average return. Many complaints were made about this system of extortion, by which, as one of our boatsteerers 
shrewdly observed, a man was compelled "e.ther to be skinned or go naked;" and the matter is now almost altogether taken out of the hands $\mathrm{cf}$ the captains. The owners affix a price to each article in the chest, and at that it is sold to the needy. Yet these prices are sufficiently high, four years interest and something additional for ne. cessary loss being charged upon the cost price of each article, on such a voyage as that we were upon; making in all about thirty per cent.

Fashion, I believe, generally takes its rise either in the desire to conceal a deformity, or in the necessities of the tailor. Among whalemen, who perform all tailoring operations for themselves, necessity has brought in vogue a fashion called "patch upon patch, and a patch over all;" and to such an extent does this prevail that it is said among sailors "you may know a whaleman by his patched shirt."

A man has two shirts, both nearly worn cut. He puts one inside the other, and quilts both together with woollen yarn, then places additional patches over the spots which yet appear frail, and congratulates himself upon the possession of a shirt which will last him, with care, for the balance of his natural life.

The Sabbath is a day of uninterrupted rest, previous to the arrival of the vessel upon her destined cruising ground. And on such days, when the weather is fair, all hands, with smooth faces and clean shirts, bring on deck their clothes 
to air them, while such as have them, look ovez' letters, and tokens from the "folks at home," and luxuriate in the remembrance of past joys and pleasures. Two of our mates were engaged to bo married on their return from the voyage we were now upon, and these poor fellows used on pleasant Sabbaths, to bring on deck the miniatures of their sweethearts at home. Looking at them, they read over their letters, and, carefully unwrapping them from multitudinous envelopes, gloated over such iittle love-tokens as they had received on their departure.

The captain and chief mate were both married men. The former was a quiet, sad looking gentlemanly man, much better fitted for the shore, than for the rongh life of exposure and privation in which his lot had been cast. He had sailed in the merchant service in his youth, and from this circumstance, I, who was a "merchant sailor," was quite a favorite with him.

On one quiet genial Sabbath day, when we had been nearly three months from home, I was standing at the helm, with eyes half closed, little minding the ship, which was lazily swinging upon the swell, the breeze being scarcely sufficient to give her steerage way. The captain was lying upon 8. mattrass, near the taffrail, reading. Presently, closing the book, he asked me how I thought I should like whaling. Not having as yet had any practical trial of the business, I could not give him a definite answer. 
"It's a wretched business," said the old man, seriously-" a wretched business. I suffer more und more every cruise I make. When I was yet a young man, the matter appeared to me in a diffurent light; but as I grow old, my desire to stay at home with my family increases, and it seems like tearing one's heartstrings to depart on a cruise with the probability of being gone four long years.

"I have bren five voyages," he continued, after a pause. "One of these lasted forty-nine months, during which time, I heard from home but once. In fifteen years of my whaling life, I have spent just seventeen months at home. I have never been present at a birth or death in my family. I can never expect more than two or three letters from home in the course of a thirty. six or forty-eight months cruise. And when I now look back upon the life I have lived-and sonsider how few and brief have been my enjoynients, and how little I have been able to contribute to the happiness of my family, -if it were not for my belief that it will be all right in heaven "-said the old man earnestly-"I should not have the courage to live."

"But, si" " remarked the second mate, who liad boen, with me, a listener to the captain's words, "I find that I enjoy myself more in the few months I remain on shore, aft $x$ my return from a voyage, than $I$ could in all the three or four years, had I remained on shore altogether. The 
long absence gives a zest to the enjoyment of home pleasures, which nothing else conld impart to them."

Here were two opinions-one that of hopeful youth, looking forward to a bright future-the other that of mature age, already grasping the future still anticipated by the first.

"Put up jour helm a little, Charley, the sails are shaking in the wind," said the captain, putting an end to the conversation, and rousing me from a very unsailorlike revery on the vanity of all sublunary affairs.

I must own I sided with the captain. His picture was a sober, sad reality. It was the raview of a life spent to but little purpose-of energies wasted, purposes defeated, and bright hopes withered. His little yarn gave me the first twinge of home-sickness I had felt for many a year. I thought of the loved ones at home, of the seven long years in which I had not heard from them, and of the apparently small hope of my ever returning thither, to sit down in peace and quietness.

In short, I was getting "blue," blue as the azure sky overhead, but not near so cheerful, when the over-ioyful cry of "Land, ho!" from the masthead, happily brought my wandering thoughts back to the present, and dispelled the gloomy fan cies which were beginning to crowd my brain.

To think is not part of the regular business of a sailor; and to be afflicted with thoughts beyond the reere present, must ever be to him a source of 
unharpiness. It is to drown troublesone thughts that Jack flies to the inebriating cup, and plunges madly into the lowest dissipation.

'The land, which seemed, as yet but a dark bluo If eck on the horizon, was the island of Tristaw d'Acunha, which we had been expecting for some dinys to see. Toward evening the breeze fresh. ened, and the following day, at 8 o'clock, we were hove to abreast of the only landing place upon the island, there being no harbor or sheltered anchorage for vessels.

'Tristan d'Acunha is the largest of a group of islets in the South Atlantic, nearly midway between the Cape of Good Hope and Cape Horn, and in about latitude 37 degrees South, and longitude 12 degrees West. The other islands are named Nightingale, and Inaccessible Island. Off the latter, Commodore (at that time Commander) Bid. dle, with whom I made my first cruise of three years, in the Navy, fought an action, during the war of 1812, with the British brig Penguin, he being at that time in command of the Hornet.

'The battle lasted twenty-two minutes, when the British vessel struck her colors and surrendered. Our old Commodore used to wear, on gala days: the identical coat which he wore that day in action, a small patch on the right arm, being the mark of an enemy's bullet, by which he that day re. ceived a wound. With a prodigality character. istic of such an old sailor as he was, he wore upon 
this coat very large flat buttons, each the size of a Spanish Doubloon, and made of pure gold.

Tristan, as the island is familiarly called by sea. men, presents to view an immense peak, rising from the ocean to the hight of over eight thousand feet. At the base of this mountain there is a nar row belt of arable land, upon which is settled the little solony which makes this dreary spot remarkable. Next to the settlement of Pitcairn's island, there is probably no more interesting or romantic instance of colonization on record, than is con tained in the story of old Governor Glass, as he styles himself, and his subjects and children.

During the imprisonment of the Emperor Napo. leon on the island of St. Helena, the British sta tioned garrisons on all the out-of-the-way pockss. within a crreuit of hundreds, and even thousands of miles. Among others Tristan d'Acunha wa chosen as the location of a troop of English sol. diers. Upon the death of Napoleon, these pre cautionary measures were no longer necessary and as the barren rock of Tristan does not lie in the path of ressels bound round the Cape, the garrison was taken off. Among the soldiers was one Glass, who had conceived the romantic idea of settling on this desolate island: after the manner of a Rubinson Crusoe.

Escaping tc the mountains when the ship whick. was to bear his fellows to the Cape was ready t. sail, he was left.' He remained for three ycr.rs in 
-olitude upon the island, cultivating a little garden spot, and amusing himself by exploring the mounlain fastnesses, and killing goats, with which tho island at that time abounded. At the end of this time an outward bound Indiaman which had gotten out of her latitude, hove in sight--saw bis signal, and bore him to the Cape. Here he remained a sufficient time to marry a half-brees native woman, and to earn himself an outfit for the novel life to which he intended to return; and then, engaging passage in a schooner bound to St. Helena, he was landed on Tristan, where he has been living ever since, in contentment and happiness.

In due course of time sons and daughters were born to his house, and with their aid he was able to so extend his agricultural operations, as to have potatoes and mutton to sell to passing vessels. The island now became a convenient calling-place for American whaling vessels bound to the Crozets, and was also visited occasionally by homeward bound Indiamen, mainly to gratify the desire of the passengers to behold with their own eyes this wonderful little settlement in the wilder ness of waters.

From the sailors of these vessels, the colony received accessions, and these new-tomers in time became husbands to the old patriarch's daughters. His sons (he had eighteen chiluron n all but mostly girls) remained with him until 
they grew up to man's estate, when several of them chose themselves wives from among the Portuguese inhabitants of the Cape of Good Hope and settled for life under the rule of their tather. who now styled himself Governor. Two enterec the American whaling service, where they hare become expert whalemen, and were officers in : New London vessel at the time of our visit to the island. They too have brought their families to Tristan, which lies at a comparatively small distance from the Crozets, and Desolation, the whaling ground of the vessel in which they are engaged.

At the time of our visit the colony numbered one hundred and one souls, a little child born but a few days before our arrival, making the first of the new hundred. There had never been a death on the island since its first settlement. The old gr vernor rules supreme, with a patriarchal sway, over the entire settlement. All trade with passing vessels is carried on by him, and all property is held in common.

'The narrow belt of land, about three hundred acres, which is arable, is cultivated in common, and each receives of the proceeds according to his need. Upon the arrival of a vessel each family states its necessities to the Governor, who barters his produce in exchange for such articles as are neoded. The "almighty dollar" is not recrgnized as a medium of exchange. With the producs of 
their land, and their herds of sheep and caitlo they are able to provide abundantly for theis comfori; and further they seek not.

In the arrangement and harmonious carrying on of his government, the old man's many daugh ters have doubtless been of incalculable advantag' to him, in procuring him numerous obedient sons in-law, who, by a law he has enforced from the beginning, must never leave the island. At the time of our visit all the marriageable women wers already disposed of. The colony did not there. fore stand in need of any extraneous accessions: else would I have been strongly tempted to have offered myself as a settler, so delightful did their peaceful and independent mode of life seem to me.

The women, who are robust and fine looking, use the rifle; the fish spear, and the oar, with a skill equal to that of their husbands and brothers. Their dwellings are comfortable cottages, mainly built of stone, of which there is an abundance. The village lies in a little sheltered nook-in front, the vast ocean, and back of it, towering abruptly skyward, the immense cone which constitutes the greater part of the island. To the right of the village and landing is the narrow strip of land which they cultivate. Their flocks and herds, not numerous but thrifty, roam in summer over the base of the mountain, and along the narrow belt of level land which runs around the island. In winter, 1 was told, they were obliged to keep them nearer home, as in stormy weather cattle were 
frequently lost in the immense rifts and fissures everywhere visible on the sides of the mountain, and which proclaim the volcanic origin of the island.

The main cone is, in fact, an extinct volcano, and we were informed that in its crater there is a beautiful lake of pure fresh water, from which issue numerous rivulets running down the sides cf the mountain and emptying into the sea.

Fishing seemed to form one of the important arocations of the colonists. They had several fine whaleboats. As we pulled toward the shore two boats' crews were engaged with hook and line. They shared with us in the evening the proceeds of a very successful day's sport. The fish caught are principally bonita, Spanish mackerel, baracouta, and a smaller kind of mackerel, such as are met with on the American shores.

They have upon the island a breed of very beautiful, long-haired dogs, somewhat resembling in expressiveness of features the Newfoundland, but not so heavily framed. I was pained to see veral of these fine animals limping about with nuge billets of wood tied to one fore foot. These were inveterate sheep-killers, and this was the manner in which they were prevented from committing their depredations.

We hove-to off the landing at 8 o'clock, A. $\mathbf{M}$. Shortly after Governor Glass came along side, in a whaleboat. He was at that time, he said, eightyfive years old, but walked as erectly, and had as 
much fire in his little grey eyes, as a man of forty After the usual inquiries as to where we were from, whither bound, and what we desired to obtain of him, he produced a list of articles which he desired to ubtain in exchange, valuing his potatoes, the only article we had come there to purchase, at one dollar per bushel. The calico, knives, and other natters which he desired, were gotten out, and lowering one of our boats, the captain proceeded to the shore with the governor, to take dinner with him, at his residence.

In the course of the day our boats brought off the supply of potatoes which our captain had purchased, and at dark we stood off on our voyage.

I think I never saw a more dreary view than the island presents from the sea. The vast waves of the Atlantic beat against the rock-bound sides, with a sullen roar which almost deafens one. The mountain's top is enveloped in a thick cloud of mist, which fills the atmosphere sometimes far down toward its base; and the air, even on shore, is strongly impregnated with the dampness peculiar to the ocean. Huge, gloomy albatrosses, and dreary little cape pigeons darted in great numbers from place to place, their shrill, discordant screams supplying an unpleasant falsetto to the bass $f$ the bellowing surf.

So powerfully does the sea beat against tho rocks, that even in the village, toward evening when the breeze had freshened to half a gale of wind, on was obliged to speak at the top of his 
I iice, in order to be heard. It seemed more like it little spot of land set adrift upon the sea, than like a veritable fastness, impregnable to the as saults of old Ocean. It is an isolated spot, ana the good people who make it their home have, to all intents and purposes, dissolved all connection with the rest of mankind. I should think it a glorious place from which to meditate upon the vanity of those pursuits in which men in the great world engage with the greatest avidity. How unimportant must appear to these dwellers in the wilderness of waters, those daily strifes and toils which engross the lives of so many in civilized lands, and which we are used to look upon as so all important. How like a fancy sketch, or perhaps, more like a communication from another planet, must seem to them the accounts in the chance papers they receive, of those wars, revolu tions, and ambitious struggles, which set that distant world agog, and furnish food for excited thought to millions of men for years of time. How like a dream, or romantic fiction, must appear cotemporary history, to a child born and raised in this out-of-the-way spot.

The night nn which we left Tristan was dark and storm-portending. As the wind was fair, however, we ran along under whole top-sails, keeping a bright look-out ahead. During my trick at the helm, from twelve to two in the middle watch, the startling cry of "hard up!" from the mate and the man on look-out, brought half the watch below 
on deck, under the impression that we were about to run into some unthought of danger. It was the hull of a vessel, mastless, and lying upon her beam ends, which we had nearly gotten foul of. The sea ran too high for us to have heard a cry, had there been any one on the wreck, and the night was too dark to distinguish aught else than a huge shapeless mass, wallowing in the waves which broke against it.

We shortened sail instantly, and lay-to till daybreak, in order to ascertain beyond doubt whether or no the wreck was tenantless. But when day broke, the hulk had disappeared, and after eruising about the spot for two hours, we were reluctantly compelled to stand on our course-not knowing but that to that wreck some poor wretch was clinging with the fixed grasp of despair, hoping against hope that his faint cry would be heard above the roar of the sea.

With a favoring breeze the thousand miles of veean which separate Tristan from the Cape of Good Hope were soon left behind us. It was upon a sunny forenoon, as we were rushing through the water, before the wind, with top-mast and lower studding sails set on both sides, that wo witnessed a most beautiful and exciting race. 'L'he log had just been hove, and proclaimed the ship to ke running at the rate of twelve knots per hour, or a mile erery five minutes. Just then. and while we, who had superintended the reeling ap of the line, were still upon the poop, four large 
porpoises came leaping over the waves, twc abreast. Unlike their usual course, which is to run counter to the direction of the wind, these four were racing before the wind, in a direction parallel to our own. Every moment they leaped out of the water, each leap seeming as though they were propelled from the mouth of a gun, so rapid and direct was the motion. Every muscle of their supple bodies was evidently strained to its utmost tension, and their bright eyes were fairly standing out from the sockets, while their short, cough-like spouts, seemed like the panting of racers. Thus they flew by us, overtaking and passing us as though we had been lying at anchor. Their rate as they passed, we supposed, must have been nearly twenty-five miles per hour.

A few days with such a breeze brought us to our whaling ground, which was, so the mates informed us, along the coast of Madagascar.

"Madagascar," said one of our factory boys to me one day, privately, as not feeling quite certain that he was not exposing an unusual degree of ignorarce in asking the question, "that is the place where the raisins are brought from; is it not? I never thought that was so far off. I think we'll get some when we go ashore there." He had evidently heard of Malaga, and failed to disi. guish between the two names.

It was finally determined that we should sail up the Mozambique channel, in the hope of there meoting with some schools which our captain 
кne iv from previous experience, to fiequent those parts of the sea at certain seasons.

It is needless to say that we were greatly rejoiced at the thought of having at last reached whaling ground. Any change was welcome, which would relieve us of the monotonous hard labor which we had experienced hitherto on board.

"What glorious times those will be, when we shall have nothing at all to do. but to steer the vessel, and keep a look out for whales," was the universai opinion. We shall see how happy if the being who has his time unemployed. 


\section{CHAPTER VI}

LEz "Cruising Ground"-What constitutes Whale Gruund-.. How the Haunts of Whales are Discovered-The Discipline of a Whaleship on a cruise-Monotony of the Life-Drawing water-Portuguese Man-of-war-Cape St. Mary's, of Madagascar-Raising a Fin-back-"There she blows"-A false Alarm-Sperm Whales_Preparation for lowering-_Going on to a Whale "_- "Give it to him!"-The Whales run-Ths

Chase-The last Desperate Effort, and accompanying Mishap - Getting stove"-A furious Whale-We are picked up, and lose the Whale.

"So wE are at last upon our cruising ground," said all, with a great degree of satisfaction, as orders came forward one evening, that at sundown we would shorten sail, and heave to for the night. It seemed like a fulfillment of one purpose of our voyage, and as it made a break in the monotony of our life, all hailed the fact with pleasure.

So much had been said of "good whaling ground," "cruising grounds," etc., that even I was looking for some peculiarity in the volor of the water, the strength of the breeze, or the quality of the atmosphere, to distinguish this fiom the other parts of the ocean. But there was nothing of the kind. The sea was as deeply blue, the breezes as gertle, and the air as hazy as it gene. 
rally is in those portions of the tropics where steady winds prevail. "Cruising ground" is a very indefinitely defined portion of the sea, chosen by each captain according to his particular fancy, or as the experience of previous voyages may dictate. Our captain had cruised on these shores, and up the Mozambique channel on his last voyage-had met with tolerable success-and now returned to the same place in hopes that his good fortune would be renewed.

New cruising grounds are continually being discovered by enterprising shipmasters, who steer boldly for those parts of the East Indian seas but little frequented by merchant vessels; and often make great voyages. Some years ago the captain of a New Bedford ship, on speaking a merchantman, was informed that near a certain part of the coast of the island of Ceylon, great numbers of whales had been seen that year. His vessel was then a year out from home, and so poorly had they hitherto prospered, that, in whaleman's language, "they had scarce oil enough on board to grease their irons." Ascertaining the precise lati. tude and longitude in which whales had been met, and judging from the description given of them, that they were beyond doubt sperm whales, the captain made all sail for the place, and found whales in such plenty that he was enabled in little more than a year's time, to fill up his ship. They were mostly cow whales, who had probably found this a new and pleasant haunt, where they hoped 
to rear their young undisturbed, with no one "to molest them, or make them afraid."

When their vessel arrived at New Bedford, the captain was immediately transferred to another ship, and taking with him all his officers, sailed back to the scene of his good fortune, and was successful in filling his ship again in a very short time. But by this time other ships had gotten on his track, and when he returned thither on his third voyage, he found the ground occupied by a fleet, and whales scarce.

All kinds of maneuvers are practiced by whalemen to conceal their cruising ground, when they have, as in the above instance, met with unusually good "luck." When compelled to go into port for water or "refreshments," (a whaling term, signifying fruits and fresh provisions generally) they will make it a point to visit some place at a distance from the newly discovered ground. If while in port they are boarded by other whalemer. both officers and crew preserve the most strbborn silence as to the location of their "ground,"or else give the inquirers false directions. And if, as is not unlikely, they find themselves followed when starting on their return, they adopt the most ingenious expedients to mislead the strangers.

$B \backsim t$ a secret of this kind can scarcely ever be kept more than two voyages. It is in the posses. sion of too many persons, and too many keen eyed whalemen are striving to fathom it.

Whales are so persistently chased and worried 
now-a-days, by the great fleets which annually sail from whaling ports of the United States, that they often emigrate in a body, and change their locality by thousands of miles. So it happens that parts of the sea which were years ago famous cruising gruunds, are now entirely deserted, while every joar new grounds are discovered, and the enterprising discoverer rewarded with a full saip, and a speedy clearance for home.

Whilo making a passage, a whaleship is managed much as merchant vessels are. The crew is divided in to two parts or watches, and all the regulations in regard to making and taking in sail, which prevail in the merchant service, are here also enforced. But once on whaling ground, the whole economy of the ship is changed. Each boat's crew now constitutes a watch, of itself, and the night, from six .P. M. to six A. M., is divided between them, making in a four boat ship three hours to each. During the day the vessel stands along under easy sail, for days together tacking and beating to windward: then if no whales are seen, going off before the wind, or returning to the leeward extreme of that portion of the ocean the captain has marked out for his "grounds," only again to beat: slowly back to the windward end.

Long tacks are made, and no expedient neglected for making a thorough survey of the surface sailed over At sundown each day the light sails are taken in, the topsail close reefed, and the vessel is then brought close to the wind, with the sails ac 
tzanced that she will lie nearly stationary, with the helm hard down. By wearing around once or twice during the night, the actual progress made, spite of the shortened sail, is as far as possible rendered nugatory, so that at daylight the following morning, when sail is again set, the vessel is as near as may be in the place where she was hove to on the preceding evening. Thus a thorough, search is kept up, two men being constantly stationed at the mast-head, while frequently the captain or mate will sit aloft for hours at a time, keeping an additional look out.

With all this vigilance and precaution, however, it is evident that the search for whales must be something after the manner of looking for a needle in a hay-stack; and unless the cruising ground is very limited in extent, which is by no means always the case, the discovery of a school may be properly counted under the head of the chapter of accidents.

When cruising, the day is passed in the most utter idleness. All hands are roused up at six o'clock, before which time it is not day in the tropics. Those who had the last or morning watch jump aloft, and loose the sails while tho others are, dressing. As soon as all hands are on deck, every sail is swayed up. The masthourl. men then take their station, and the word $\mathrm{iz}$ passed to "wash down, fore and aft."

After the decks are thoroughly scrubbed, washed off, and dried, the cook announces breakfast, and 
with this the daj's work is finished. After breakfast each one busies himself about his own affairs. Some mend their clothing, some read, some play cards, while yet others return content. edly to their berths and doze off the long hours till dinner time. The afternoon is but a repetition of the forenoon, and with the exception of ar or casional call of all hands to "tack ship," and the necessary shortening sail at sunset, no one is called upon for labor of any kind.

We had looked forward to this period with anticipations of great pleasure-over worked as the crew was, on the entire outward passage. But man tires of nothing so quickly as a state of inactivity, and so we were not a week upon the whaling ground, ere every one complained of the weary monotony of such a life. Every one, that is to say, except our Portuguese. These seemed to be perfectly contented and happy. They had brought with them upon this voyage most of the clothing used by them on the voyage before, and had consequently much more mending, patching and quilting to do than the rest: more therefore, to engage mind and hands. And then, they had each undergone already one long voyage of ennui and their spirits were broken to it. By the time we had gotten a month's experience of the cruising ground, I no longer wondcred at the wandering, lack-luster look, the shuffling walk, and awkward appearance generally, of your regular old whaleman. His mind has been gradually killed out by lack of use. 
In the routine of duty, while cruising, the labor of drawing water for the matin washing of the decks, is the most severe that is performed It seems to be a principle in the whaling service that as there is exceedingly little work to be done chat little should be made as laborious as possible, as a means of making the crew more contented in their leisure hours. Instead, therefore, of providing a head-pump, by means of which water could be pumped up from along-side, it is all drawn up by men stationed at the side for that purpose. This is exhausting labor, under any circumstances; but doubly severe when, as is often the case, the breeze is light, and the ship scarcely under headway. Under such circumstances the swinging of the huge awkward canvas bucket requires an outlay of strength which soon becomes a positive torturc.

It was shortly after our arrival upon the cruising ground that, being one morning over the side, drawing water, I for the first time experienced the effects of the poison contained in the nettle-like stings of the nautilus. It was a beautiful morning, and as is their wont at such times, the little argonauts had their sails spread, and could be seen in all directions, careering gallantly over the waves. By accident I caught one little fellow in my bucket, and in emptying him out, the mass of jelly (they are mere balls of jelly-like fibre) fell upon my bared arm. It was instantly wasbed off, but too late to save me from the sting. 
In a short time my arm assumed a purple color, and became slightly swollen. At first I experienced a titillating sensation, which, however, soon changed to a violent throbbing pain, and shortly a lump about as large as a peach appeared under my arm-pit. The pain lasted about an hour, when it gradually subsided, and in two hours more, all evidences of the poison had disappeared.

It was the intention of our captain to make the coast of Madagascar, about Cape St. Mary's, its southern extremity; and taking thence a fresh departure, to cruise slowly up the Mozambique channel. Accordingly, a few days after we had entered upon our regular cruising tactics, the cry of "Land ho!" broke upon the dull monotony of our life, and in a few hours we were close to a bold, barren bluff, which we were informed was the southern extremity of Madagascar. I viewed it with a great deal of interest, for it was a land I had long desired to see, having while yet at home, read much of its inhabitants, of its good king Radama, and of the persecutions suffered by the missionaries and native Christians, after his death.

Standing off again, after approaching sufficiently near to see distinctly all objects on the shore which, however, was to all appearance entirely desert. the vessel was now headed for the coast of Africa, distant from this point of Müdagascar abont one undred and seventy miles.

Each day the officers now became mnre anxious 7 
to see whales. It is quite usual with whalemen, at least to meet with whales on their outward passage, and not at all uncommon to take some raluable prizes before reaching the regnlar cruising grounds. Up to this time, however, $\mathrm{w}^{\mathrm{B}}$ Lad not yet seen a spout, except that of an occasional black-fish or finback, and had not succeeded in capturing even a porpoise. We were now three months out and had not yet on board oil snough to keep a lamp alight in the forecastle-a sad prospect for men to whom oil is the representative of dollars, and blubber, of the native ore.

"Five dollars" said the captain, one morning as the men repaired to the mastheads, "to the man that raises a sperm whale spout.".

"I'll put three pounds of tobacco to that," spoke up the mate.

"And I a bunch of cigars," said the second mate.

This set every one agog, and after breakfast the rigging and mastheads were crowded with men, eager to win the promised reward.

But it was not on that day, nor the next, that we were to fall in with the objects of our search. Not till we had been two weeks upon the ground, did we see a spout of any kind. Then ono forenoon, a shrill, discordant scream, of "there! shel blows!" from the fore-masthead, proclaimed that somosody thought himsclf entitled to the promised reward.

All hands rushed upon deck, and the captain and mate were half way to the royal cuasthead 
ere the repetition although in a very moderate tone, of the first cry, assured them that there was in reality a spout seen. Casting his eyes in the direction indicated by the masthead-man, the mate exclaimed at once, with a disappointed growl,

"It's a fin-back, you leather-head, there's no prize offered for such."

"I told him so," grumbled the boatsteerer who stood at the main-masthead, "but he would not believe anything I said, thinking I wanted to claim the prize for myself."

Two days thereafter, as the mate stepped into the rigging, at daybreak, to take a preliminary survey, he shouted, in the utmost excitement, "there blows! there! there blows!! by the great horn spoon, boys! a whole school just under our lee bow."

All hands were upon deck in a moment, and the greater part of the crew at once jumped into the rigging, anxious to see at last a veritable sperm whale spout, and half prepared from the mate's excited manner, to see the whales themselves close aboard.

About two miles and a half off, on our lee bow. a small school of what the captain, examining them with a good telescope, declared to be large whales, lay disporting themselves on the waves, now lazily rolling "fin up," now "lob-tailing," now making the white water fly, as they threw their rast bodies clear of their native elemen: 
Sail was immediately made upon the ship, and then, while the masthead-men with the captain, kept us the musical cry of "there blows!" varied occasionally by such ejaculations as "there's white water!"-_ there he lob-tails!"- " there he breaches!" we hurriedly prepared the boats for the day's work before us. Line tubs were placed, and lines bent on, iron sheaths taken off, and a last whetting given to the irons, boats' gripes cast adrift, and oars loosened and laid in their proper places, water kegs filled, boat sails unlashed, and all the various minutiæ duly attended to which experience has proven necessary for such occasions. All was life and bustle, and the stagnant pools of our blood were once more enlivened by a little real excitement.

"There goes flukes!" from the masthead, proclaimed the close of the first scene of the day's drama, and immediately thereafter,

"Breakfast all of you," from the cook, caused each man to rush hurriedly to the galley for his quota of hot slop - coffee it is called by courtesy, but no one who had ever drunk Mocha, Java, or Rio, would own it to be such.

Hastily washing down a couple of biscuits with this preparation, we were ready for the word to "man the boats," and were at the side as soon as the captain showed his head above the gangway. "Stand by to lower away, you ship-keepers," war the word now, and we prepared to follow the 
boats down as they werc lowered, ready to leap into them as soon as they should strike the water.

In attempting this feat, one of the second mate's srew mistook the distance, and fell into the water, from which he was fished up, sputtering and shivering, receiving from the captain the consolatory advice to "never mind that, as it was all clean water down there."

It was a beautiful morning. There was just enough of breeze to make the sails of more use than the oars, and sufficient sea to admit of an easy approach to whale. The glorious sunrise, such a scene as is to be witnessed only in the tropics, the balmy air, and the unwonted excitement, all united to put us in excellent spirits, and many a joke was exchanged on prospective mishaps, as we put up our boat sails and set out for the scene of action.

The position which each of the four boats was to take had been previously arranged, and as the whales had not appeared to be in motion when first seen, it was supposed that they would rise not far from the place where they had gone down. Accnrdingly, when we judged ourselves within, about a quarter of a mile of this spot we hove to our boat, preferring to remain at that distance to windward, as it would be easy enough to sail down, - but more difficult to pull up, did we fall to leeward. 'The other boats were shortly hove to likewise, and 
now we lay in silence, awaiting the reaprearance of our prey.

Every cye and ear was on the alert, ready to i atch the slightest motion or sound; for none could tell how soon the school would make their appear ance at the surface.

"I thought I heard a spout," said the boatstcerer in a whisper. In his eagerness re had gotten upon the bow chock, anxiously peering over the waves as the boat was lifted upon the swell. A moment's silent listening convinced him that it was nothing but a sea-break, and we again strained our eyes for the expected sight.

"There blows!-I told you I would see him first," said the mate, joyfully, as he pointed to a thin bushy spray just melting out of sight.

"There blows again!" cried the boatsteerer, adding in a somewhat mortified tone, "I was looking another way, or I should have seen it first."

"There, and there-and there-tbere blows!there are seven or eight big whales-I can seo them now from my place," continued Barnard, the boatsteerer, whom I was yet holding up on the bow chock, the dancing motion of the boat making it impossible for him to maintain that position unsupported.

"Sit down now, and we'll sail slowly down toward them; I want to see in what direction they . are going to stand."

We were nearest to the fish, and it was evident 
that no other boat but ours, could approach them farorably.

"Pull a little," said the mate.

We shot her rapidly ahead with the oars for a few strokes, and ther peaked them again, tho boat making good headway under her sail alone.

We could now hear them spout, and when a heavy swell would come rolling home, would fancy we could hear their huge bodies burrowing through the water. It was a time of intense excitement.

"We'll have to stand across a little, in order to get up behind them," said the mate; it being impossible to approach a sperm whale unperceived from the side.

After making a little detour, we again stood boward the school, and the mate singled out one huge fellow nearest us, and happily the largest of the school, as our prize.

Each individual of the crew had received from the mate, on first lowering, some final instructions as to his especial duties, in case we should get fast; and we now sat stock still in the boat, oars firmly grasped and ready for instantaneous use, and sicarce breathing from excitement. We were fast overtaking his whaleship.

Now the hoarse bellow, as he ejected the water from his spout holes, grew louder, and looking over my shoxlder as the boat was lifted on a mighty swell, I saw the huge form of leviathan, stupidly rolling in the waves. 
"Stand up, you sir," the mate whispers to the poatsteerer,--a needless command, as that worthy has not jet sat down, and now stands with iron poised in hand, and knee resting firmly on the labber chock, ready for action.

"Pull a little, starboard."

The boat is laid round, to get a fairer chance.

Now she rises on a wave and the fish seems almost under us, and now-

"Give it to him, you sir!"

"And the other one!!"

A heavy stroke of his flukes, which drenched us with spray, and the instantaneous whiz of the line through the chock, told that we were "fast."

"Hurrah!" shouted the glad boatsteerer, "wet line! wet line! don't you sce it smoking in the chock?"

Flake after flake of the line rushed overboard, with a rapidity almost beyond conception; one tub was already empty, and half the other was gone before a little slacking in the speed of its exit gave us to understand that the whale had "gone his length," and was now probably returning to the surface: an operation which would take out line nearly as fast as the first sounding, were it not that it is held back by several turns about the loggerhead in the stern. The mate had meantime taken his place in the bow; and the lances were out, and lying in their rests when the whale reappeared on the surface some ship-lengths ahead, leaping nearly his entire length out of the water, 
and falling back with a report like distant thunder, and a splash which for the moment threatened to fill the boat.

"Haul in slack line, boys, let's get up to him. There hc lios, quite still; take your (Iars and pull up."

But the weight of the line hanging overboard rendered $t$ impossible to manage her, and we were compelled to get this in first." By this time the whale was slowly forging ahead, evidently scarcely knowing what course of action would be most politic under the circumstances.

"Now haul up."

Having gotten a strain on the line, we pulled the boat on. But just as we got within dart, the whale again sounded-not deep however,-and when he reappeared, the rest of the school were with him, and they were going off at the rate of səveral miles per hour, of course taking us with them.

Now however, we hauled the boat up, and the mate sent a lance quivering into his flesh-but not into a fatal part, as we could not get far enough in advance of our fish to afford a fair chanee. With a splash of his flukes, the whale sonnded again, and commenced running under water, a proceeding which was kept up during the whole of a chase which lasted from this time-about half past eight - till after four i'clock, when occurred the cajastrophe which wound up ox day's sport. 
The whales-there were seven in all-ran to the teeward, that is to say, in a direction parallel to ihat of the wind: contrary to their usual practice in such cases, which is to sart at once right in :be teeth of the breeze.

While their present course made it much easier for the boats to follow and perhaps catch up with us, it much increased the difficulty of our approach, for the purpose of lancing, as in such cases much care is requisite, elso would the boat be dashed upon the whale by the billows which bore her onward.

We had, however, lanced but twice-both times ineffectually - when the fish increased their speed to seven or eight miles per hour, and running almost continually under water, it was altogether impossible to reach our whale with the lance, even had we been able to get the boat sufficiently near to him.

On, on, on we swept, the other boats, with sails and oars, pulling might and main to catch up with us, and the ship, with every rag of canvas set, bringing up the rear.

Whenever there seemed a possibility of reaching the whale, the boat was hauled up and a lanco duly hurled at him; but with little effect, as his small was the part most generally hit, and each wound seemed only to add to his speed. This was soor such as that-the breeze having to somo degree failed-we were fast dropping ship and boats in the distance. 
At one o'clock, by the sun, we ate our ainner, consisting of a biscuit and a pint of water per man-rowing internally, and taking our empty stomashs to witness, never again to get into a whaleboat, without previously filling our pockets with provisions.

At two we saw the last of the boats, and shortly afterward the royals of our ship faded away in the dim distance, leaving us quite alone with ous huge friends, who were still going along at the same rapid pace, and puffing away like so many Mississippi steamers.

On, on, on, we were borne, seemingly as though never to stop. Now the school would slack a little in their speed, and we would haul up to lance. Then they would start up again, and for half an hour at a time we would sit still, singing songs, or devising plans whereby we might circumvent our wary enemy.

"Be jabers, it is much better to sit here idle, than to be sweating at the oars, as the other boys are doing," said an Irish Yankee, who pulled the tub oar. "An, be gorra, it's our first whale, any how, let them talk as they will."

"It's not our whale till we kill him, Paddy; they don't count whales till they are tried out and stowed down," remarked the mate.

"If that's the case," was the answer, "it's time we were getting a nearer view of him than we've had yet."

The mate evidently thought so too. Wearied 
with waiting for a favorable opportunity, about four o'clock it was determined to make a desperate effort, running every risk for the sake of get ting a dart at the whale's life.

"Pull the boat up," said the mate, with an ait which showed that something was to be done.

"Now Charley," to the present-writer, "hang on to the line, and don't slack till I give the word. Take it out of the chock, and let her shoot ahead by the bow cleat."

"Lay the boat around,"-to the boat-steerer. This maneuver gave us a better chance, and : lance was sent quivering into his body. A stroke of his flukes on the water just ahead of us, was the quick reply.

"Hold on tight-don't drop her an inch astern," cried the mate, as the whale came to almost a dead stop.

"Now I'll get a set on you!" he muttered between his clenched teeth, as the boat shot up against his broad side. He placed his lance fairly, and sent it home, with the whole weight of his body. As it touched his life, the whale dashed down head first, in the motion striking his flukes against the boat's bottom, and breaking two or three planks. No sooner had he felt her, how. ever, than turning with lightning speed, he returned to the surface head foremost, open-mouther., striking and thrusting with his long, slender jaw. as though it were a sword. One blow from this jaw stove in the whole bow of the boat, and she 
filled and turned over, almost before we could leap into the water.-

To grasp oars, and whatever else would float, Tas the first act of each, on finding himself overboard. The mate in a few minutes succeeded in gaining the bottom of the wrecked boat, and with his assistance the rest gathered there, each keeping in his hand an oar to assist him when, as frequently occured, a sea larger than usual swept us from our narrow perch.

The first glance about us disclosed to us our antagonist, lying at the distance of a short oar's length from the boat, side and side with us. He was spouting thin blood, and the disagreeable thought suggested itself at once to several of us, "Suppose he goes into his flurry while we are lying here helpless."

"We must hope for the best, boys, and meantime look out for the boats and the sharks," was the mate's answer to this suggestion. "But if he goes off in a flurry, you need none of you expect to see your mamma's again."

When we had hoisted a shirt upon a lance-pole, as a signal of distress, and lashed three oars across the boat, to keep her from continually rolling over barrel fashion, we found ourselves at the oud of our resources, and had leisure to look our fate in the face. It is needless to describe how anxiously we watched each motion of the whalehow the color of his spouts was critically discussed, and every spasmodic twitch of his flukes 
was thought portentous of evil. Suffice it to say, that fortunately for us, the mate $\mathrm{s}$ lance had not touched him in any very vulnerable spot, and that after lying for half an hour side by side with the boat, and for another half hour in such a position that with every swell our boat's sharp stern rubhed against his side, just as the sun sank boluw the horizon he turned flukes, and to our great relief, came up at a distance from us of some half dozen ship's lengths. It shculd have been before mentioned, that from the moment when our boat was stove, all the other whales who had till then borne us company, disappcared, and we saw them no more.

Scarcely had "our whale" risen to the surface, when we descried a boat-sail at but a short distance off. It was fast growing dark, as there is scarcely any twilight in those latitudes, so that it was with no ordinary joy we hailed the approach of what proved to be the Captain's boat.

"Are you all there?" he asked, as he came within hail.

"Yes, sir."

"Well, just hang on there till I kill your whale," was the cool rejoinder. Saying which, he turned the boat toward the fish. She had scarcely got. :en within two boat's lengths cf him when, snap ping his jaws together with a sharp report which showed that his ire was fully roused, the whalo made for the boat.

"Stern all! back water for your lives!!" cried 
the captain, slipping the sheet; and furturately, just in time to escape the angry rush of the whale, who glided beneath the surface, and rose again at a short distance astern.

The boat was laid round, and a few strokes of the oars brought her again within his reach, when be repeated his former action, and it was only by the most strenuous exertion that the crew succeeded in backing out of his track. This time, however, the boatsteerer had managed to plant an iron in him, and a shout announced that he was not given up yet. But a groan of disappointment succeeded the shout, as the line suddenly slackening, announced that the iron had drawn, and the whale was "loose," going off with two irons and two tubs of line fast to him, and spouting blood at that.

It was now quite dark, and we were not sorry to be taken off our wreck into the captain's boat. Meantime the other two boats and the ship bad neared us, and after half an hour's pulling we arrived on board, where a good supper, (for a whaleship), awaited us.

"Well, Paddy," said the mate next morning, as wo were washing down the decke, "what wiil y ? take for your share of our first u iale?" 


\section{CHAPTER VII.}

Errting a new Boat-We raise Whales again-Our Boat gets fast-The Whale takes out the Line-The Mate despairsSunset-The third Mate refastens-The Mate kills the Whale-"There's Blood "-The Flurry_Getting a Fish along side-Cutting in-Wrenching off the Head-The Teeth-The Junk - The Case - Extraordinary gathering of Sharks Their Rapacity-Trying out-Horse-pieces--Blanket-pieces-Mincing-Division of Labor-A Night Scene-Nauseating Labor-Picking out fat-lean-Stowing down the Oil-Clearing up Decks.

Our first labor, on the following morning, was to fit a new boat, to replace the one lost the day before. There were, as before mentioned, three spare boats overhead, and one of these was now turned over, and swung to the davits. Il required the labor of several days from our boat's crew, ere we were once more so cornfortably fitted as in our old boat. There were lines to be stretched and coiled, and re-coiled. There were irons and Iances to be ground sharp, and fixed to their poles. There were numberless little beckets and cleats to be nailed and fastened in numberless little out of the way nooks and crevices about the bow and stern. There were thole-pins and thole-pin maty to fit. There was a boat-spade, and boat-hatchet, 
an 1 boat-compass, and water-breaker, and boatsail, and divers nameless little necessaries to proride and fit.

To see all these articles lying together upon leck, before they were placed in the new boat, one would scarcely have believed that one little whale boat would contain them, and her crew of six fullsized men into the bargain.

We made all possible haste with our new boat, that we might not be left on board, should whales be seen. Our shipmates had laughed at us on account of our mishap, and we felt therefore anxious to retrieve our credit, by a more successful stroke. There can be no one more ready to succor the really distressed, nor any kinder sympathizer in affliction, or more faithful nurse to the sick, than the sailor. But a long familiarity with danger hardens him to it, and no one gets credit for being accidentally placed in an awkward or helpless position.

Had any one of our crew been injured by the blow of the whale which destroyed our boat, that individual would have met with the kindest of treatment from every soul on board. And when the captain's boat's crew saw us lying helpless on the remnant of the boat, nothing could have equaled the heartiness with which they pulled to our rescue. But when it was once found that we were in no immediate danger, the sympathy which they were prepared to extend to us vanished, and was replaced at once by a desire tu laugh at the 8 
ludicrous figures we presented, clinging like hulf drowned rats to the wreck. This was exempli. fied by a half laugh which followed the captain's words to us, "Well, you may stay these a lictle while."

On our return on board, we were unmercifully quizzed, and any lurking desire to have ourseives considered the heroes of the day, was nipped in the bud by numerous inquiries as to whether salt water bathing was likely to restore us to health and vigor; whether any one had ventured to ride on whale-back; whether any one had thought of making a propitiatory offering to the whales; or whether we had not wished ourselves safe at home, "tied to mamma's apron-strings."

"Never mind, boys," said Barnard, the boatsteerer, to us, "we'll show them how to kill the next whale, and give them a chance to laugh another way."

And we were fully determined to do so.

It was not many days before we had an opportunity to put in practice our determination. The officers were very anxious to take at least one whale before we should fall in with any of the vessels then known to be cruising in the Mozambique Channel, in order to retrieve by that the. late mishap, as well as to have it to say that we had made a fair beginning. Every day, therefore, the mastheads and upper yards were crowded with eager lookers out, determined to let no spout or blackskin escape their keen gaze 
It was about a week after our mishap, that whales were raised, little more than a mile to wind. ward. There was a fresh breeze, and more se: than a boat could be comfortably pulled agrainst. But at this time we would have "lowered" in a gale of wind. Moreover, a moderately rough day, such as this was, is considered a much better whaling time than when there is little wind and a smooth sea; as it has been found that whales will not run so fast, and oftentimes will not run at all, thus becoming an easy prey.

The whales - three in number - were slowly drifting to leeward. They were discovered about ten o'clock, A. M. We worked the ship to windward until one o'clock, keeping well ahead of them, and then, having gotten into what was considered a favorable position, took advantage of their sounding, to "lower."

"Now, my lads," said the mate to us, after we were some distance from the ship, "if we do not get fast and kill our whale to-day, I shall think we have not done our duty; and if we do, you'll have a bunch of cigars each."

He could not have spoken more to the point, and the crew looked a determination to "put him on "to the first fish that showed himself.

The breeze was so strong when we left the ves rel, that she could hardly carry her main top. gallant sail. Yet when we had pulled the boat to tho spot near which the whales were expected to rise, we set our little boat-sail, a mere 
han lkerchief, as it were, and the lively buat danoed merrily over the waves, taking in not a drop of water. Nothing can exceed the buoyancy of one of these little cockle shells. From their peculiar build and shape, they are especially caiculated to withstand a seaway; and there are instancos on record which prove that a whaleboat, rishtly managed, (which however, requires great $\varepsilon k r l l$ and unceasing vigilance) will live in a gale of wind in which many large ships shall make vorg uncomfortable weather.

"Thers he blows," sung out the boatsteerer, pointing ti a white spout on our left, and nearest the second and third mates' boats, which were for this time eruising in company, the fourth mate being not far from us.

"It's their chance," said the mate with something of disappointment in his voice, and we prepared to look on at their maneuvers, trusting to forlune tor an opportunity for ourselves afterward.

But by the time the other two boats had been pulled around so as to approach the whales from ahead - a matter requiring in such a seaway, snme time-they had already sounded again.

For some half-dozen risings we were thus held in suspense. Sometimes it was our chance, somelimes that of the others, but at no time did the fish remain on the surface a sufficient length of time to give us a fair opportunity for getting fast. The ship had been worked to windward all tho 
afternoon, under the direction of the aaptain, who had doubuless been watching our actions with no little anxiety as to the result. The sun was now but about half an hour high, and a waif (a little white flag) had just been displayed from the peak of the ship, to bid us prepare to return on board.

"There's the waif, sir, and the captain's keep:ng off to run down to us."

"And there's the whale, by the hook block! and now we'll keep off. It's our chance, boys, hurrah!"

"Take down your boat-sail, and pull the boat round."

It was done before the words were fairly uttered. The boat was pointed toward the whale, who was lazily wallowing in the trough of the sea, evidently unsuspicious of danger. We did not need to pull. Once fairly before the wind, the waves bore us on at the rate of some six or seven miles per hour. A few minutes brought us within fair sight of the whale; a f'ew strokes of the oars placed the boat so far ahead of him as to enable us to approach him unobserved.

"Stand up, you sir."

"And now pull, you scamps-pull hard, ha f a dozen strokes-spring your oars, boys!"

"So-let her run!"

"Give it to him!!"

Before a second iron could be darted, the whale had disappeared beneath the foaming surge; bot 
the lightning-like volocity with which the line was disappearing over the bow, told plainly snough that the first iron hat hit him.

He was sounding with a fearful speed. Beforo we could fairly realize that we were fast, uno tub was emptied of its line, and now the mate, who had not yet had time to jump to the bow, (always the first evolution after the whale is struck), hurriedly bent a "drug" - a thick flat piece of light wood, about two feet square-to the inner end of the line, which is always left exposed for this purpose. This was scarcely done when it was snatched out of the mate's hand, and striking one of the crew a slight blow on the head, disappeared with the balance of the line, overboard.

As the drug vanished from our sight, the sun was sinking beneath the waters. The poor mate tore his hair, in agony at our ill luck, while we sat silent, thinking of what seemed to be a perverse fate. There was scarcely a hope that the whale would rise again before dark, as the twilights in those latitudes are exceedingly short. Yet there was a hope, and every eye now scanned the water, trusting to catch some sign of the whale's reap. pearance

"Don't look for the drug-it's too dark to see that. You'll scarce see a whale now, more than three ship's lengths off."

Minute after mincte we lay there, every $\&$ ye otrained, every heart beating with inxicty. It 
was now too dark to distinguish even the bnats, which were under sail at a quarter of a mile's distance, and with sinking hearts, we were ono by one abandoning the lookout, and turning our eyes toward the ship, when

"There, by George, there's the whale - th chird mate has fastened to him," shouted tho mate, jumping up and down with joy.

Giving vent to a shout of exultation, wo bent $t=$ our oars, and were soon within hail of the fast boat.

"Don't you lance that whale-he's got our iron in him and I want to kill him-blast him," shouted the mate, hoarse with excitement.

The fish lay, quite still upon the water, and the third mate readily gave place to us. We took hold of his line.

"Now pull me up to the beast."

"Take the line to the bow cleat, and then take a turn about the bow thwart, and hold me to him till I churn him!"

The boat was brought in contact with the whale's side, and while I held her there, by a turn of the line as directed, the mate set the long slender lance fairly over his life, and sent it home, repeating his thrust again and again. A treczendous quiver of the vast body, and the issue of a mass of clotted blood from his spout-holes, were the immediate consequences.

"There's blood - hurrah!" was exultingly shouted at the top of every voice. It is a cry 
which the whaleman at all times utters with joy ; but with us it was doubly joyful, because of the sudden transition from previous depression and hopelessness, to present certainty of victory.

"There he rolls it out, thick as coal tar," suid he mate, as he heard a hoarse gurgling sound-it was too dark any longer to distinguish between blood and water.

"Stern now, men, stern all-quick!"-as the whale rolled over in his flurry.

The command was given none too soon. And now he beat the waters with his flukes, and darted hither and thither at immense speed, in his death struggle. From the distance to which we had removed for safety from an accidental stroke, we could not see his actions; and it was fearful to list to the swift blows of his flukes, and know that but a little way from us, in the thick darkness, a leviathan was parting from life.

His flurry was short. The mate's lance had been too well pointed."

Meantime we had set our boat-lantern, and the ship now bore down toward us, with two lights in her rigging, glaring upon us as though she were some great monster come to the assistanco of its brothe1 Two boats had returned on board, and we of the remaining two now prepared to take a line from the vessel, by which to pass a mooring chain about the dead whale's flukes. The sea was quite high, the night pitch dark, and altogether, I soon came to the conclusion tha1 
the worst part of our business was yet to be dons:

Ip order to keep the whale in a proper position for watting in, a chain is placed round that part called his small-the tapering extremity to whic $n$ the flukes or tail is joined. This small, in a whale, is not small by any means, being about the circum ference of a flour barrel, and deserving the name only by comparison with the balance of his body.

When dead, a whale lies upon his side, with one fin out of water. He floats just upon a level with the water, the flukes and small being completely below the surface. It is, therefore, not a slight undertaking; particularly at night, and in a heavy sea, to pass the necessary line. The operation is performed by two boats, in the following manner: A light line is provided, weighed down at the middle by a six or ten pound shot. Each boat takes one end of this line, and one being stationed on either side of the whale, they pull siuwly toward his head, with the intention of passing the bight, or middle of the rope, beneath the whale's body. Four times we tried this experiment, but each time the line was caught in the fork of the fukes, which, lying now perpendicularly in the water, reach to a considerable extent beneath the surface. The fifth time we were successful, and with a shout passed the ends of our line to the ship where the rest of the manipulation is gone through with; it being the office of the boats now to preserve and hold tightly the middle of the 
rope, in order that it may not be again swept from its place by the waves.

To the small line is bent or fastened a stout rope; next comes a hawser, and at last the chain is slowly paid out overboard, one end being first passed through a ring in the other. The slipnoose or "running bight" thus formed is finally tightened about the whale's small, and he is secure. Additional irons were now put into the whale, and the lines passed on board, that we might not lose our fish, should an accident happen to the chain; and then the carcass was slowly hauled up to the side, and secured for the night.

It was nine o'clock before we of the mate's boat got on board, to change our wet clothing and obtain a bite of supper. The watch was then set, and orders given to those on deck to get up the cutting gear, and clean out the try-works, preparatory to the labors of the succeeding day.

At early daylight all hands were called from their warm berths, and the bustle and-labor of cuttingin began. Stages were slung over the side, whereon the officers stand with long-handled spades, to cut the blubber. Tackles were got up to the mast, wherewith to lift the ponderous blocks and ropes used for hoisting in the blubber; the blub. ber rorsm was cleared of a mass of rubbish whicn liad accumulated there during the outward passage, and then, breakfast being over, the real labor of the day was commenced.

The whale lies with his head toward the stern 
of the vessel. The first thing to be done is to sep. arate the head from the body. To this purpose, a place being fixed upon where it is supposed the back bone can be separated, a deep incision is made with a spade. A strip of the adjoining blubber, about six feet wide, is now cut loose on both sides, and an incision being also made longitudinally in this strip, a boat-steerer goes down in a "bowline," to hook on the first "blanket-piece."

This done-and this is about the most difficult and dangerous duty in cutting-in a whale-the crew heave away at the windlass, and the officers cut away on each side as necessary. The whale is thus rolled completely around, the thick blubber peeling off easily from the flesh beneath. The deep incision next to the head is continued, the spade being thrust down till it strikes the vertebra; and thus by the time the carcass has made one entire revolution, the head hangs merely by the joints which connect it with the backbone.

A stout oak post is now placed with one end resting against a plate prepared on the ship's side, and the other inserted in a hole cut in the head. The cutting and hoisting recommences, and as the whale's body is slowly turned, the head, which is kept stationary by the post, is gradually. wrenched off. Previously to this, however, a head-chain has been passed through a hole made for the purpose, and by this the severed mass now hangs. When the head is loose, the body is hauled forward clear of the gangway. The lower jaw- 
or jaw, as it is called, the balance being the head proper - a long, slender bone, is severed and hoisted in. In this are contained the teeth, which are ralued as ivory, and worked into various fancy articles during subsequent leisure hours. A sperm-whale's teeth are placed in such a marner as to hook back, and are moveable in their sockets.

Now comes the head, the most important part of the whale, as it is a nearly solid mass of blubber and spermacetti. Where the whale is large, this is now again subdivided, the entire mass being far too heavy to hoist in at once. It was judged that our whale would make about sixty barrels. This is above the average, and the case, that part of the head which contains the pure spermacetti, was therefore separated from the rest, and hoisted in first. This safely landed, the head was swayed, and on reaching the deck, was shoved art, on the quarter deck. It barely fitted under the beams which supported the spare boats, and formed a cube of nearly nine feet. How much it weighed, I would not attempt to guess. The case, which was placed against it_tackles being required to slide it along the well-greased decks-was nearly as large.

The cutting-in now recommenced. As cne tackle reached the masthead, another was bruught down and hooked, or rather, toggled in at the gangway. The upper piece was ther sut loose, and lowrered down into the blubber-room, where it lay, with the blackskin down. 
Long before this time-in fact, with early day. lightm-an immense number of sharks had gath. erec around the ship, attracted thither by the blood and scent of our prize. As far as the eye could distinguish them, their dorsal fins could be zeen gliding over the water, all hurrying to the scenu of slaughter, eager to secure a share of the prize. The extraordinary number of these sea lawyers present, was equaled only by their rapacity. Before we began cutting-in, they had already commenced their meal. Taking advan. tage of a heave of the swell, a shark would wriggle up on top of the whale, and setting his wide opened mouth against the solid blubber, would bite out a piece as round as and about the size of a man's head. The officers spent their leisure moments in cutting at them with the spades, and one man was stationed abreast of the whale's head, with a long sharp spade, to keep them off that part. I saw one cut in such a manner that his entrails protruded into the water, and yet this animal, which it was to be supposed would almost inmediately die, wriggled itself up on the whale, ind took out a huge mouthful, paying for its lemerity by having the greater part of its tail sut coff.

It is almost impossible to kill a shark. They have as many lives as a cat. The amount of sufforing they will undergo before death ensues, is really marvelous. I have seen all the entrails taken out of one, and yet after lying about on 
deck for an hour, he bit and crushed a stout ash pole between his teeth. They remain about the ship until the carcass is set adrift, when they divide the rich prize with the sea-birds. There are few instances on record of a shark having bitten a man while cutting-in. There is too great a superabundance of other food. Boatsteerers, whose business it is to go down upon the whale to hook on the first blanket-piece, an operation requiring sometimes fifteen or twenty minutes to execute, are scarce ever molested. The mate stands by, however, with a spade, ready to meet any advances on the part of the sharks. I have seen a man working on the whale, with a shark close beside him : he simply giving the fish a kick with his heavy sea-boot, when he became aware of its close proximity.

Meantime the cutting-in proceeded; and, by dint of strenuous exertions, we finished this part of our labor at five o'clock, P. M. The gory carcass was then set adrift, and floated off to leeward. a huge bone of contention to innumerable sharks and sea-birds.

The first thing now to be done was to start up the fires. The enormous blanket-pieces had been piled into the blubber-room 'until it was full to the brink, and now two men, stripping off their shirts, and enveloping their heads in cotton handkerchiefs, got on to this mass of grease to cut it up into horse-pieces, morsels about fourteen inches iquare. These again were thrown upon deck, 
and passed forward to the mincing-horse, where, witl two men to turn and one to feed the machine, sufficient blubber to fill our two try-kettles was soon minced. This ready, the fires were started, first with wood, the dry "cracklings," or scrape, as they are called, being afterward used for fuel.

Numerous empty casks were now hoisted on deck, coopered, and lashed along the bulwarks. Into these the oil was bailed, after being allowed to cool in a copper tank adjoining the try-works, and there it remained until quite cool, when it was stowed below. Meantime the case was opened; a man being placed in the large opening, the pure and beautifully white spermacetti was bailed out with a bucket constructed for that purpose. It is quite fluid when first taken out, but quickly congeals on exposure to the air. It is at once placed in new crsks, which are duly marked " case."

The shell, when completely empty, was with much labor and by the united strength of the whole crew, hauled to the gangway, where, divesting it of tackles, we took advantage of a favorable lurch of the ship to launch it overboard. The case itself, although closely resembling blubber, is in fact a huge mass of tendons, muscles and fibres, so closely interwoven as to be almost impervious to the harpoon or spade. It yields no oil by try. ing out, and is therefore fitly thrown away.

Next, the junk, the remaining portion of the head, was cut into horse-pieces and tried out separately, the oil from this part of the whale being 
regarded as greatly superior to the rest, the sperm. acet,ti being, of course, the niost valuable. It was not until I was set to work upon this enormous mass of solid blubber, that 1 fairly realized the size of th 3 animal we had slain. This huge cube of nearly nine feet, was only a portion, perhaps a fair half of his head. What then, thought I, as I slashed away at it, my puny strokes seeming like those of an ant nibbling at an apple, what then must have been the size of his entire carcass.

Our trying-out operations were in "full blast." The watch had been set at eight, one-half the crew being kept on deck for six hours, which is the duration of a trying-out watch. On such occasions each man has a particular duty assigned him. The mates and boatsteerers superintend the try-pots, feed the fires, and ladle out the seething oil into a copper cooler. Three men are con. stantly employed at the mincing machine; some pitch horse-pieces from the blubber-room hatch to the machine; while sthers have the care of the casks, rolling them up to be filled, and afterward securing them. One at the wheel and another on look-out, with a few to look on, and "spell" the rest, complete the list.

At night, our ship presented a highly picturesque scene. The flames, darting high above the try-works, revealed the masts, rigging and decks, ir an unearthly glare, among which the men jumping or sliding about decks on their various 
duties, seemed like demons dancing about an incantation fire. But with this picture all the romance departs. The smell of the burning cracklings is too horribly nauseous for description. It is as though all the ill odors in the world were gathered together and being shaken up. Walking upon deck has become an impossibility. The oil washes from one side to the other, as the ship lazily rolls in the seaway, and the safest mode of locomotion is sliding from place to place, on the seat of your pantaloons.

Moreover, everything is drenched with oil. Shirts and trowsers are dripping with the loathsome stuff. The pores of the skin seem to be filled with it. Feei, hands and hair, all are full. The biscuit you eat glistens with oil, and tastes as though just out of the blubber room. The knife with which you cut your meat leaves upon the morsel, which nearly chokes you as you reluctantly swallow it, plain traces of the abominable blubber. Every few minutes it becomes necessary to work at something on the lee side of the vessel, and while there you are comrolled to breath in the fetid smoke of the scrap fires, until you feel as though filth had struck into your blood, and suffused every vein in your body. Fr: $m$ this smell and taste of blubber, raw, boiling and burning, there is no relief or place of refuge. Tho cabin, the forecastle, even the masthesds, all are filled with it, and were it possible to get for a 
mom nt to clean quarters, one would loath him. self-reeking as everybody is, with oil.

It is horrible. Yet old whalemen delight in it. 'The fetid smoke is incense to their nostrils. The filthy oil secms to them a glorious representative of prospective dollars and delights. They wallow in blubber, and take a horse-piece for their pillow when lying down. They bake doughnuts and biscuit in the seething oil, and portions of the whale's lean meat are prepared for their daily dinner. I was induced by curiosity to try a piece of nicely cooked whale. The raw meat is of a dark red color, nearly black, and somewhat resembling very coarse beef. It is generally minced fine, and fried, after the manner of forcemeat balls. I could not stomach it - although our captain declared, with his mouth crammed full, that it was the best thing he had tasted for a long time.

Three days our trying out lasted. The closing scene was the worst. From the fact that the blubber is torn off the whale's sides, it unavoidably happens that occasionally a piece of meat is brought up with the blanket-pieces. This is known as the "fat-lean," and is carefully stripped from the horse-pieces, and thrown into large oren casks, where the heat of the sun and of the adjacent fires gradually drain it of the oil it contains. This being of an inferior quality, is left to the last day, and by that time the meat 
green and putrid. Men are now set to work to fish out those pieces not considered of sufficient value to try out, and pitch them overboard. For this purpose one has to lean with his head quite inside the open cask, and inhaling all the noisome stench arising from the decayed mass within, feel around with his hands, to grasp the slimy morsels which are not fit for the try-kettles.

The captain and I worked side by side at one cask for a half an hour, at the end of which time I was obliged to say that I could not stand it longer. I was deathly sick.

"That's nothing, Charley," said he, "just fancy it's dollars you are groping among, and the matter will assume a very different odor." But I thought that too high a price for dollars.

The third affernoon we tried out our last kettle full, and put out the fires. The blubber room was now cleaned out, the various utensils used for the past three days, stowed away, and the decks cleaned up a little. Two days longer the oil was kept upon deck, to give it time to cool thoroughly, and then the labor of "stowing down" began. Rolling huge oil casks across a slippery deck, while the ship is pitching and rolling in the seaway, is a task of considerable labor. This, too, came to an end at last, and then ensued a grand cleaning up -decks, sides, bulwarks, forecastle and cabin, all received a thorough cleansing, and at the end of two or three days more, the ship again looked like the habitation of Christian men. and 
Ne, her crew, were again in good odor with our selves.

It is a fortunate circumstance that sperm oil will wash off easily, not leaving any stain upon wood, and but little upon the rough clothing whalemen wear. The smoke and cinders make the chief dirt, penetrating as they do, every part of the vessel, and bearing with them that peculiarly sickening smell of burning meat, the remembrance of which, even to this day, disgusts me. Happy day it was for me, when I was once more permitted to put on clean clothes, and could eat biscuit without oil, and meat unaccompanied by the tarice of blubber 
"Gamming"-Sail ho!-The Betsy Ann-Her Crew-A "Mer. chant Sailor"-A Council-A school of Whales-A race between two Whale boats-The Offer to share the Chances refused-It is our Whale-The Bazaroota Islands-Procuring Wood-A strange Fish-Harpooning Hippopotami-We cause one to "spout blood"-Tow it Ashore-Hippopotamus SteakA Night Visit to the Shore for the Purpose of Killing a few Hippopotami, with its Results.

Meantime a sharp look-out was kept up for whales-although I believe the crew generally were quite willing to have no more trying out to do for some time-even if dollars were not gathered so fast in consequence. But we now daily expected to fall in with some other whaling vessels, which our captain supposed to be cruising in this latitude.

Next to a run on shore, a "gamm," as it is called-that is, a social reunion of the crews of two ships, accidentally meeting on a cruise-forms the pleasantest incident in a whaling voyage. Then are old times talked over, old friends inquired after, pasi adventures related, and a mutual interchange of the good things of whaling life effected, all tending to make the few hours deroted to this social intercourse as pleasant as possible. 
It was about a week after we had stowed down our oil, and cleaned ship, that one morning the cry of "sail ho!" brought all hands on deck, and caused the captain to run quickly aloft with his spy-glass, to reconnoitre the stranger. The vessel's course was imniediately altered so as to intersept the strange sail, and various speculations were hazarded by officers and crew as to her name, business, and hailing place.

"She's a wha'er, that's settled," said the third mate confidently; "else she would not be here." "Then we'll have a gamm, boys, hurrah!" cried a boatsteerer.

Soon her top gallants were visible from the deck; and now the mate, just returned from the masthead, declared his belief that she was not a "Natucketer;" a very welcome piece of intelligence indeed, for such is the jealousy existing between rival whaling ports, that many Nantucketmen refuse to "gamm" with vessels hailing from "the Sound."

"The skipper thinks its the Athenia, which left New London two weeks before we sailed," said the mate.

"We may bless our stars that we have got a whale on board, else we should be ashamed to look those fellows in the face."

"There goes her burgee-oh fror ten thousand spy-glasses now."

"She's the Betsy Ann, from New Bedford; 1 
k low her," hails the captain, now descending from the masthead.

We were soon irformed that the Betsy Ann had oeen nearly three years from home, and that she had a smart crew, who were not to be beat in get. ting on to a whale, by any set of men in those seas. In a short time the strange vessel was within hail, wher the usual salutations were exchanged. And after duly informing them that wo were four months out and had taken one whale, a week or so ago, we were told in return that they had now nineteen hundred barrels on board, had seen no whales for three weeks, and thought of steering for the Isle of France, in hopes to fall in with some off the shores of that island.

“Wont you come aboard, Captain Starkweather?' asked our captain.

"Yes, I'll lower my boat; let your mate come aboard of us."

Filling our pockets with tobacco, and our shirtbosoms with books, we of the mate's boat were soon ready, and lowering the boat, pulled on board the Betsy Ann, a rusty looking old tub as ever floated.

We were received at the gangway by as motley an assemblage of tanned faces, long beards, and patched garments, as I ever saw. They spoke in low tones, automatically held out their hands to $u s$, and then, two of our fellows having hooked sur boat on, she was hoisted to the davits of the captain's boat. Now filling the main-top-sail 
we stood on, thus losing no ground by ous enjoyment.

Our first reception had seemed to us ecol. We were languidly asked down into the forecastle. which smelt abominably of decayed roaches and cil soap, and here seats were given us on the chests. Once seated, all hands preserved a most decorous silence for nearly ten minutes, when one of the strangers at last ventured to ask how long we were from home, and what was the latest news.

Being duly posted on this topic, they again relapsed into silence, and I was beginning to think that gamming was an unmitigated bore, when I was accosted by a tall fellow, whose patches, being of colors a little different from those of his shipmates, had struck me from the first as not " native, to the manor born." He asked me, with a doubting smile, whether I was not a merchant sailor. An earnest "yes," produced a hearty shaking of hands between us, and an immediate proposal on his part to adjourn to the deck, where we could talk matters over more at our leisure.

Stowing ourselves snugly away on the topgallant forecastle, we took such a turn at yarning as probably neither of us had enjoyed for a long time. He was a Scotchman, and had shipped as carpenter of the vessel. This was his first whaling voyage, and he expressed an opinion, whech 1 very emphatically indorsed, that whaling was an enormous, filthy humbug. 
Ben--that was my new friend's name-was an uld sailor, and had seen a good deal of the world. We had therefore a good deal to talk about, and a great many places to compare notes on. First, however, I laid before him my free-will offering of tobacco and books, requesting him to share the former with any other good fellows on board. This, together with the fact that I was a merchaw sailor, procured me shortly an enlarged acquain. tance on board, all who were in the good graces of Chips seating themselves around us to listen to our yarns.

The hardships to which the merchant sailor is exposed, beyond either the man-of-war's man or the whaleman, and the strange vicissitudes of his life, procure him, in a superior degree, the esteem of all other classes of seafaring people. Whether in the polished man-of-war, the dirty whaler, or the diminutive fisherman or coaster, a merchant sailor, as he is always first at the post of duty or danger, is allowed to place himself first at mess, or in the council. It was thus that I found Chips looked up to with respect not unmixed with fear, by the rest of his shipmates in the forecastle, while the officers valued him above any other half lozen of the crew. And it was thus that I, while cordially hated by the greater part of my verdant shipmates, was yet able to exact sufficient respect from them to make them defer to my opinions, and leave my property unmolested.

I explained to Chips my position on board ship, 
and disagreement with the greenhorns, whom 1 could look upon only as speaking brutes-witk several exceptions of course.

"I'll tell You, Charley," said he, " the reason why they hate you. You assert for yourself the posi. jion of a man, but have not the beard necessary to a tacit enforcement of your claims. If you've been in a lime-juicer, you know that there one is considered a toy till he can show a pair of whiskers, and a man ever afterward, if he's as stupid as a donkey, and as lazy as a first class whaleman. This is sailor human nature. If it was not for the little whiskers I can raise about my face,"-his features were barely discernible through a most enormous black beard-"I should have to fight these fellows every day of my life."

"All except the Portuguese," added he, "they are a good sensible set of fellows, who mind their own business, and act upon the square in everything." "Wait till I have a beard," thought I, with an internal vow, that when that blessed epoch in my history arrived, I would assume and assert, at all hazards, all the dignity and prerogatives of mature manhood.

"Meantime, Charley," said my new friend very coolly, "handspikes, applied about the shins of those who prove troublesome to you, will be found sn excellent substitute for hair on your chin."

In such talk we passed away very pleasantly a couple of hours, I meanwhile regaling myself upon the contents of a jar of most delicious tamarinds, 
which Ben had brought up for my use. After the long and wearisome insipidity of salt junk and biscuit, bean soup and duff, the lively acid of the preserved tamarinds was most refreshing; and during our conversation I "stowed away" a large proportion of the contents of the jar before me. It was only when one of our Portuguese friends set another jar beside me, expressing at the same time a desire that I should "eat heartily, and give the ship a good name," that I was made aware that I was gormandizing.

Our enjoyment was very suddenly brought to a close by a cry of "there she whitewaters," from the masthead of the Betsy Ann. While upon a gamm, both vessels' mastheads are manned as though no visiting was going on, and upon a discovery of whales, under such circumstances, there generally ensues some hard racing, and not unfrequently hard feeling.

Every one was upon the alert in a moment, as the cry reached the deck. It was followed by the regular intonations of "there blows," convincing us that a school of sperm whales was in sight. Our boat's-crew at once gathered together upon deck, to hold ourselves in readiness for lowering. The mate, after watching our ship keenly a moment, and satisfying himself by the unusual bustle on board, that the whales were seen from there too, came to us, and warned us that this time we should have to contend against four of the smartest 
roats in those seas, and that it would not do to bo beaten altogether.

We had already talked the matter over among ourselves, and determined to do our best, and not be beaten if we could prevent it. I think there was not one of our fellows that did not wish the whales in Tophet, or that did not already think of our crew as beaten. Nevertheless, "never say die while there is a shot in the locker," is a motto upon which we determined to act,.and so each man gathered up his strength for the encounter.

The Betsy Ann's erew, meantime, had beer. busied in preparations for lowering, ever and anon casting a meaning half-smile toward the spot in the waist where we had gathered together. They evidently feared not the result-they made sure of an easy victory over the greenies.

The whales were nearly ahead, and when we should lower, would be about half a mile nearer to the Betsy Ann than to our vessel. We had therefore the best chance, although the others had the weathergauge.

When within a mile and a half of the schnol, the vessel was hove to. Every boat was instantly lowered and manned, and we at once stretched away for the whales. Our ship's boats had low. ered a little before us, and were coming down from the windward upon the whales, straining overy nerve to get upon them before we should. We had scarcely pulled two hundred yards, how. 
ever, when the fish suddenly put a stop to our racing by turning flukes. This gave us time to pull leisurely down toward the spot where they had disappeared beneath the waves, and here each boat.header now brought his boat to in such a position as he judged most favorable for the prospective " rising."

The chase was so exciting that our old captain, leaving his fourth mate on board to work ship, had come in the boat, and was now urging us on to do our best, and "show these fellows that they had their match."

All was now arranged. The eight boats lay in various positions; all in the circumference of two miles. Our mate, and the mate of the Betsy Ann, had chosen the same spot, and although, as courtesy demanded, each had removed his boat some distance f'rom the place we had both at first intended to sccupy, yet the two boats were in most unpleasar $t$ proximity to each other, and we plainly saw that, did the whales rise in the vicinity, a des perate race would be the consequence.

"Pull your best, boys-but (to the mate)' be careful of your boat-I would rather lose a whale, than have a boat stove, and perhaps two or three an h hurt, Mr. Osborne," were the captain's final irstructions, as he pulled off to take up a position in another part of the field.

All was now silence. No one ventured to speak abovo a whisper, fearing that the sound of his voico might drown the distant spouting of a whale 
In evory face the most intense and anxious excito. ment shone forth. Oars in hand, sleeves and trowsers rolled up, feet firmly braced against the stretchers, and hats pushed down over our brows, we sat in grim silence, the compressed lips and flashing eyes of our crew plainly saying that we would not be beaten without at least a struggle.

The fact is, the ironical smiles of our gamming acquaintances had stung us to the quick, and we were determined to show them that to beat us was not so easy as they chose to believe.

Minute after minute, (and every minute seemed half an hour), passed away in anxious waiting, and yet no whales appeared.

"So many boats in the water at once, gallied them, I guess," said Barnard, in a desponding tone of voice. He had wagered some tobacco against a lot of sperm whale's teeth, that if there were opportunity for a race, we would not be beaten.

"There's a ripple," whispered the mate just then, and he gently laid the boat round.

"And there blows, boys, pull your best!" he said, yet speaking only in a hoarse whisper.

The whales were beyond our rival's boat, and she had therefore the advantage of us by half a dozen boats' lengths. Part of this was, however, lost again, by their negligence in not seeing the whales as soon as we did, and we had the boat fairly under headway, almost as soon as they were laid round in the proper direction.

Now ensued a race, such as I never before o1 
since witnessed. We were yet about a boat's length astern. Both crews were pulling with all the strength at their command.

At the measured strokes of the oars, the slender boats seemed almost to leap clear of the wave, and fly through the air. Their dull roll in the rollocks, their regular dip in the water, the rush of the boat's bow, as it came in contact with the waves, the quick, loud breathing of the men at the oars, and the half-smothered voices of the boatheaders urging their respective crews on to renewed exertions, all proclained a race in which nut only a fish, but the honor of the two ships was thought to be at stake.

The whales were yet unaware of our approach. They were going slowly round in a large circle, as is often their habit, and their present courso was of material advantage to us, as it forced both boals so to alter their course as in a short time to bring us abreast of our opponents. A whispered shout testified our appreciation of this advantage. But we had no breath to waste in shouting. Every bit was needed for the contest.

"Will you halve the chances, Mr. Swain?" asked our mate, seeing our present advantage, and yet feeling that withal, a new boat's crew might be beaten, and willing to make sure of half a whale, rather than run the risk of gaining none.

"No," was the quick and somewhat haughty 
answer, "every $\mathrm{m}$ an for himself, and the devil for us all!"

"Pull hard, boys-bend your ash!-lay to her, you devils! - strain your muscles!" urged the mate, in earnest whisper, as he himself pusher with might and main against the after oar.

The whales had risen about three-quarters of a mile from where we lay awaiting them, and a much greater distance from any of the other boats, whose crews were now pulling after us, simply as witnesses to our race, and to be at hand in case of accident.

"Pull hard!" said our mate, glaring with blood shot eyes upon the mate of the other boat.

"Lay to your oars, men," urged that worthy as he anxiously watched our boat, and found him. self unable to drop us.

Meantime the steady click of the oars, and the rush of the boats through the water, filled every. ear.

Now we fast neared the whales. Now a huge spout seems to be uttered not a boat's length ahead. A motion of the hand upward, tells the boatsteerer to stand up.

He peaks his oar. The boatsteerer in the other boat does the same.

"Give way now, men, for your lives," urges the mate, still in a whisper.

Both boats are aiming for the same whale, whose huge broadsidr. lies exposed not threedarts from us 
Now he hears us. Will he sound? No; but gallied for the moment he increases his speed. Hurrah, this givos us an advantage! But so little that it still seems as though both must fasten.

"Pull hard, boys," shouted our mate, now at the top of his voice.

"One more stroke!"

"Another!!"

"And another!!"

Each time intensifying his tones.

Like shouts ring from the other boat. It is now plainly our "chance."

"Will you halve the chances, Osborne?" asks the Betsy Ann's mate.

"Not if I know it," is the curt reply-"Pull, I tell you."

"Give it to him," he shouts in thunder-tones, as the boat brings up violently against the broadsid، of the whale, throwing nearly every man out of his seat with the shock. "Back water, quickstern all, I tell you," is the cry, as the whale slowly settles a little in the water, and then rapidly strikes out with his flukes.

To pitch himself into the bow, to tear a lance from its rest, to aim it at the whale's breast, now exposed, as the wounded beast lashes the water in his pain, and to send the slender rod to his lifeall is the work of scarce a moment; and when, a minute afterward, the whale rolls up to spout, the joyf 11 shout of "there's blood," ringing over the sea, proclaims the end of the race and battle. 
Meantime, the disappointed mate of the Betsy Ann had gone off after another whale, whick, for. tur.e fivoring him, he succeeded in killing a little before sun-set, after a tedious chase.

"I'll beat you yet, on a fair race, Osborne, hailed he the next day, as cutting in, the two ships drifted near together.

"Never mind the racing; we got the whale," was all the answer vouchsafed to this taunt.

When done cutting in we separated, and each steering his own way, we saw no more of the New Bédford man.

Standing slowly along the African coast, we one day, nine or ten days after our rencontre with the Betsy Ann, sighted some low, thickly wooded islands, skirting the mainland, and forming with that a sort of rude road-stead.

"Those are the Bazaroota islands," said the vaptain, as I stood at the wheel; "I've heard them spoken of as a good place to obtain fire-wood, and as we shall need some before getting to any better place, I guess we'll drop in there."

The glad tidings were soon known to all on board. The anchors were hurriedly loosened on the bows, the chains bent, and a few other preparations made for bringing the ship to for a couple of days. In two hours we were in five fathoms water, about two and a half miles from the main. land, the islets lying at various distances, from half a mile to three miles from us. Herc the ship was brought to. 
Thu Bazaroota isles are situated in the Mozam. bique, at but short distances from the coast of Africa, as before said, and in about latitude $21^{\mathrm{c}}$ $20^{\prime}$ 'south, and longitude $36^{\circ} 12^{\prime}$ east. They con. tain much wood, and but very few inhabitants, both which circumstances contributed in the present instance to making them a favorite place of resort for our captain.

We sailed into the little bay about nine o'clock one morning, and after coming to anchor, furling sails, and clearing a place in the hold for the re. ception of the wood, placed axes in the mate' boat, and in her proceeded to an inspection of the facilities for cutting and boating off fire-wood, afforded by the different little islets.

To cut a supply of wood for a whaling cruise, is a work requiring some days, and often even weeks, and it had been determined that the first, and if need be the next day likewise, should be devoted to a thorough inspection of the facilities of the place, in order that we might work at as little disadvantage as possible.

Consequently we, the mate's boat's crew, had been ordered to prepare for a general cruise. We provided ourselves with a store of bread and beef, filled the boat's breaker with water, spread our sail to the light breeze, and pointed the boat's bow toward the nearest island. Landing here, wo found nought but a wilderness of low jungle, which was scarcely penetrable, together with a poor landing We examined three or four of the 
islets, and having at last fixed upon a suitable place where to commence operations, wero about to return on board, when the mate said,

"Trim aft, Tom, there's a good breeze, fair soming and going, and we'll take a look at the mainland." Accordingly, the boat's head was laid shoreward, and we spread ourselves out at full length upon the thwarts, enjoying an unusual treat of some cigars which our chief officer had good-naturedly brought with him.

When within about a mile and a half of the main land, we found the water shoaling, being then not more than three fathoms-eighteen feet -deep.

"I saw black skin glisten in the sun just then," said the boatsteerer, who was aft, the mate having stretched himself upon the bow thwart to take a nap.

"It was nothing but a puffing pig," said he drowsily.

"There it is again, and no puffing pig eithernor porpoise-nor-no," said he with some degree of animation - "nor anything else that wears black skin that $I$ ever saw before."

This had the effect of rousing us up, every one casting his eyes ahead to catch a sight of the [uestionable "black skin."

"There he blows!' — "and there again!"- "and over here too," said several voices in succession.

"It ain't a spout at all, boys, let's pul! up and seo what is "' 
We took to our oars, and the boat was soon darting forward at good speed toward the place where we had last seen the objects of our curiosity.

"Stern all!" suddenly shouted the mate, as the ooat brought up "all standing" against some object which we had not been able to see on account of the murkiness of the water, the collision nearly throwing us upon our backs into the bottom of the boat. As we backed off, an enormous beast slowly raised his head above the water, gave a loud snort, and incontinently dove down again, almost before we could get a fair look at it.

"What is it?" was now the question-which no one cuuld answer.

"Whatever it is," said the mate, whose whaling blood was up, "if it comes within reach of $\mathrm{my}$ iron, I'll make fast to it, lads—so pull ahead." We were again under headway, keeping a bright look out for the reappearance of the stranger.

"There they are, a whole school," said the mate, eagerly, pointing in shore, where the glistening of white-water showed that a number of the nondescripts were evidently enjoying themselves. "Now boys, pull hard, and we'll soon try their mettle."

"There's something broke water, just ahead,' said the boatsteerer.

"Pull easy lads-I see him-there-way enough -there's his back!"-

"Stern all!" shouted he, as he darted his iron into a back as broad as a small sperm whale's. 
"Stern all - back water - back water, every man!" and the infuriated beast made desperate lunges in every direction, making the white-water fiy almost equal to a whale.

We could now see the whole shape of the cress. ture, as, in his agony and surprise, he raised him self high above the surface. We all recognized at once the Hippopotamus, as he is represented in books of natural history.

Our subject soon got a little cooler, and giving a savage roar, bent his head round until he grasped. the shank of the iron between his teeth. With one jerk he drew it out of his bleeding quarter, and shaking it savagely, dove down to the bottom. The water was here but about two fathoms deep, and we could see the direction in which he was traveling along the bottom, by a line of blood, as well as by the air bubbles which rose to the sur. face as he breathed.

"Give me another iron, Charley, and we'll not give him a chance to pull it out next time."

The iron was handed up, and we slowly sailed in the direction which our prize was following along the bottom.

"Here's two or three of them astern of as," said the boatsteerer.

Just then two more rose, one on either side of the boat, and in rather unpleasant proximity, and before we had begun to realize our situation, the wounded beast, unable any longer to stay beneath the surfacs, came up to breathe just ahead. 
"Pull ahead a little; let's get out of this snarl. Lay the boat around-so-now, stern all," and the iron was planted deep in the neck of our victim. With a roar louder than a dozen of the wild bulls of Madagascar, the now maddened beast made for the boat.

Back water!-back, I say! Take down this buat. sail, and ,itern all! Stern, for your lives, men!" as two more appeared by the bows, evidently prepared to assist their comrade. He was making the water fly in all directions, and having failed to reach the boat, was now vainly essaying to grasp the iron, which the mate had purposely put into his short neck, so close to his head that he could not get it in his mouth.

"Stick out line till we get clear of the school, and then we'll pull up on the other side of this fellow, and soon settle him with a lance."

This was done, and as we again hauled upon the still furious beast, the mate poised his bright lance for a moment, then sent it deep into his heart. With a tremendous roar, and a desperate final struggle, of scarcely a minute's duration, our prize gave up the ghost, and after sinking for a moment, rose again to the surface, lying upon his ejle, just as does the whale when dead.

His ccmpanions had left us, and we now, giving three cheers for our victory, towed the carcasa to the not far distant shore. It was luckily high tide, and we got the body up to high water mark, where the speedily receding wares left it ashore. 
When we here viewed the giant, and thought of the singular agility he had displayed in the water, we could not help acknowledging to one another that to get among a school of Hippopotami would bo rather a desperate game.

On measuring, we found our prize to be a few inches less than fifteen feet long from his head to the commencement of his short, hairless tail. We could not measure his girth, but his bulk was enormous. His legs were disproportionately short, giving him, conjointly with his short neck and very large head, an awkward, stolid appearance, which the agility he displayed in the water by no means justified. His skin was very thick and very tough, and almost altogether devoid of hair. His head was shaped a little like that of an ox, but his mouth was very large, and furnished, aside from a set of stout grinders, with four tusks, two on each jaw, from ten to twelve inches long, which, together with a peculiarly dull, savage expression of the eye, gave him a most wicked appear ance.

We had not been long on shore, when several natives made their appearance. They testified much joy at sight of our prize, and went through a most lively pantomime, from which we gathered that the beasts were a great plague to them, that the meat was good to eat, and that they would like a portion. The hint was not lost upon us, who had not tasted fresh beef for some six months. "What say you, boys, will you try a piece of 
Hi popotamus steak?" proposed the mate; and as no one dissented, we got the axes, and after socsiderable chopping and hacking, cut off the read, when we were enabled to cut ourselves about twenty-five pounds of what appeared to be toler. ably tender meat, off the fore quarter.

With this supply, and some tusks which the natives gave us, we proceeded on board to relatc our adventure. Our steaks were cooked for supper; and whether it was that we were blessed with an unusually good appetite, that the cook excelled himself on that occasion, or that the meat was actually well flavored, certain it is that the steaks were delicious.

We paid some further visits to the shore, but at the captain's orders, kept out of the way of the river-horses, as he did not choose to risk a boat, and perhaps her crew, where no profit was to be gained. We gathered from the natives that the Hippopotami infested the country about there in great herds, and often in one night destroyed all the rice fields in the neighborhood. We were shown two large pits, on the borders of a field, in which already several had been caught. These holes are dug by the natives with sticks and rnugh wooden spades. Sharp stakes are driven in the bottom; the whole trap is covered over ith boughs of trees and old wood, that it may look like part of the path which the beasts make in their daily peregrinations down to the water side, and it is complete. As the troop comes up from 
the water after night, on an incursion, the leader generally falls a victim to the ingenuity of the natives. But they, not having any weapons wherewith $t_{4}$ despatch their huge prize, are obliged :o let the poor beast starve to death in his narrow pit, securing thus naught but their revenge and the tusks, which last are valuable as ivory.

Our curinsity had been aroused to see an entiro herd comirg up out of the water to go inland, and at the instance of the captain, a party of us, including him, armed ourselves and took up a position the next evening about sinset, just on one side of what appeared to be their principal line of march, among a thicket of large trees. We remained at our stations, in the dark, until about nine o'clock, listening with astonishment to the gambols of the unwieldly monsters in the water close to us. It had been proposed, (before coming on shore), to fire at the herd as they came past our hiding place, and our muskets were loaded with ball for that purpose. But the first signs of their coming put all firing out of our heads, and each one shrank back behind his tree, only too glad to escape their notice. The noise they made in coming on, was as though a tornado was sweeping through the woods. The roaring was terrific; the very earth seeming to tremble at the sound. Three of us, who had concealed ourselves behind an enormous tree, where we bad been merrily boasting of how we would "pop down the Hippopotami," now shrunk close 
together, each one laying down his musket, seady for instantaneous flight.

The creatures were evidently aware of our presence, for as they passed us they sniffed the air suspiciously, and breaking into a waddling trot, made the welkin ring with such deafening roars that for awhile it seemed as if all the beasts of the forest had joined in concert. When the troop was past and out of hearing, we crept out of our hiding places and hurried down to the boats, glad to escape without a battle, and perfectly willing to leave hippopotamus hunting to those who were better provided for the sport than we. 


\section{CHAPTER IX.}

No Whales-Tediousness of the Life-Expedients tc is c Iime -The Habits of Sperm Whales-Their Food-The Sperm Whale Squid-Its Arms-The Whale's Teeth, and how it is supposed that he uses them-Means of Defense possessed by Whales-The right Whale-The Humpback-Quicknese of Motion of a Sperm Whale-Lowering in a Calm-Difficulty of approaching a Whale at such a Time-He Listens-Sudden disappearance-Chasing a Gallied Whale-Rainy WeatherBourbon-Determination to leave the Vessel at the first 0pportunity-The Coast of Madagascar-A Story of St. Mary's Shoal.

IN four days we completed our supply of fuel, and on the morning of the fifth after our arrival, once more set sail for the middle of the channel. Our last whale made us forty barrels; we had, therefore, one hundred barrels of oil on board, which at so early a period of our voyage (we were not seven months out), was considered highly encouraging. Yet the time was beginning to hang very heavily upon our hands, and our experience for a month and a half after leaving the Bazarootas-during which time we never saw a sperm whale spout-entirely disgusted me with the business.

The captain proposed to go into port for refresh 
ments, when we had three hundred barrels of oil on board, or in our eleventh month out from home. Meantime, however, we were ever in the vicinity of some shore. Land was plainly in view for days at a time. Either the blue mountains of Mada gascar, or the flat, desert-like beach of the oppo site A frican coast, were ever in sight. And thus we drifted along, day after day, with nought but the semi-occasional trick at the helm or masthead to excite the sluggish blood, and relieve the constant dullness of our monotonous lives.

By this time I had read all the books in the ship - many of them treatises on mathematics: political economy, and other dry and unentertaining subjects. With the lassitude inspired by our lazy life, even the spirit for reading had left me, and my mind refused to arouse to the consideration of an author. Card-playing I was long ago disgusted with. Sing, I could not. Stand at the masthead when it was not my turn, I would not. And so I, in company with two boatsteerers, took to whittling as a last resort, and with the help of pieces of soft wood and sharp knives, we got through some weary days, and many feet of cedar plank. One resource the others had, of which I was deprived-they chewed tobacco; and a quid engaged not only their jaws, but by sympathy their minds.

I no longer wondered at the vacant stare and odd manners of the poor fellows on board the Betsy Ann. Their long confinement on board 
ship, tne entire absence of objects by the consid. eration of which their minds would be kept in a healthful state of excitement, the wear some monotony of their every day life--were enough to crush any mind, however strong. I watched my. self with alarm, lest I too should be getting into that absent, awkward habit. And I determined that at the first port I would take my leave of whaling-not conceiving that $I$ was bound to remain where I plainly saw that both mind and body would wilt away.

Those of the crew who could sleep the greatest number of hours were, in these days, the happi. est. And as in all things else, so in sleeping, practice makes perfect: so that ere long some of my worthy shipmates thought no harm of deroting from thirteen to fifteen hours of the twentyfour to the god Morpheus.

Meantime, I took advantage of the seasons of idleness, to gratify a desire, long entertained, to know all that is generally known of the habits of whales. Sitting upon the booby-hatch, whittling, I would ask questions of the boatsteerers, until they sometimes declared me to be an arrant bore. The mates, too, were pressed into my service, and many a tough yarn, as well as many scraps of curious information, I gathered as the result of these random questionings.

Sperm whales feed upon an animal knowa among whalemen as "squid," but which is, I ke. lieve, a monster species of cuttle fish. These. 
like their smaller congeners, cling to the rocks, the larger species of course, having their haunts at the $\mathrm{b}$-ttom of the sea, while the smaller frequent oniy the shores of bays.

Very few' men have ever seen an entire squid or sperm whale cuttle-fish, and I incline to the belief that mist of the few instances on record, of their appearance at the surface, are apocryphal. Whalemen believe them to be much larger than the largest whale, even exceeding in size the hull of a large vessel; and those who pretend to have been favored with a sight of the body, describe it as a huge, shapeless, jelly-like mass, of a dirty yellow, and having on all sides of it long armis, or feelers, precisely like the common rock-squid. This an:mal is no doubt the "kraken," of which old hisiories speak as having often borne down entire ships in their grasp, and as able to annihilate a fleet.

The anımal seldom exhibits itself to man; but pieces of the feelers are often seen afloat, on good whaling ground. I have examined such from the boats, and found them to consist of a dirty yellow surface, beneath which appeared a slimy, jelly-like flesh. Of several pieces which we fell in with at various times when in the boats, most had on them portions of the "sucker," or air exhauster with which the common cuttle-fish is furnished, to enable him to hold the prey aboat which he has slung his snake-like arms. These floating pieces are supposed to have becn bittep 
ur torn off by whales, while feeding at the bottom Many of those we saw were of the circumference of a flour barrel. If this be the size of the arms, of which they have probably hundreds, each furnished with air exhausters the size of a dinner plate, what must be the magnitude of the body which supports such an array?

The teeth of a sperm whale, which are found only in the lower jaw, are conical in shape, coming to a round dull point at the end. They set in the gum in such a position as to hook backward, and can be moved in their sockets by the hand. Nevertheless they are very firmly fixed, having to be drawn by means of tackle. Experienced whalemen suppose them to be used principally to tear loose their prey from the rocks. The sperm whale has a tolerably capacious gullet, which is evident from the fact that sometimes, when about to die, he vomits forth pieces of squid larger than a barrel.

There is I think, no more beautiful exemplifica. tion of the wisdom and foresight of the Creator, than is seen in the instinct and means of defense given to each of the principal species of the whale. Tbe sperm whale has the power of seeing any object which approaches him from any point on his side, his eye, to this purpose, being placed at the end of his mouth, and nearly one-third his length from the beginning of his head. He can not however, see the approach of an enemy from right astern or right ahead. But here, 
Providence has placed his chief defunses. With his huge flukes, he strikes perpendicular blows upon the water, or at any object which may annoy him there, while with his tremendous head, or strll more fearful jaw, he destroys all which comes within reach. He has likewise an acute sense of hearing, although his outward ear is no larger than a pin-hole.

The right whale, on the other hand, can not, on account of the peculiar conformation of his head, see any object either ahead or abreast of him, but distinguishes best that which approaches him from behind. To protect himself, therefore, against assailants whom he can not see, he is enabled to sweep with his tail or flukes from one eye to the other, thus rendering any approach to his body, from abreast, impossible or highly dangerous.

The hump-back, who is but a poor mongrel, partaking of the nature of both sperm and right whale, invariably runs to windward on being attacked, and that with such velocity as to make pursuit almost useless. The only time when an attempt to take one of these fish is prudent, is thereiore, in a calm. On such occasions the poor brute runs vainly round, snuffing for the breeze, and quickly falls a prey to his enemy-man.

Sperm whales are now much scarcer than in years past, owing to the number of vessels which anrually fit out from America and various parts of Europe, partly or entirely in pursuit of them. 
In times past, when they were not so continually worried and followed, they were much easier to approach, although often giving battle wh en attacked. Now, however, the utmost care is required to "get on " as it is termed. The slightest noise causes them to disappear with marvelous celerity.

Though so vast and apparently unwieldy, the motions of a sperm whale are sometimes almost inconceivably quick.

We had left the Mozambique Channel, and slowly sailed down the eastern coast of Madagascar, toward the Isles of Bourbon and Mauritius. It was on a beautiful calm Sunday morning, that the masthead-man raised a large sperm whale, about three miles off. An hour's close watching convinced the officers that he was feeding, and was entirely unsuspicious of our presence. At the end of that time he turned flukes, and we lowered, and pulled up to what we thought the most advantageous spots to await his rising. A nice little breeze had by this time sprung up, and we set our boat sail, determining to sail on to the whale, should he come up near us.

The whale remained beneath the surfaco netrly an hour, an evidence that he was a large fish. We had begun to think he was gone off, when he spouted about quarter of a mile from us, and in such a position that our boat, which was immedi. ately abead of him, was the only one that conid 
approach him unperceived. The others remained till, while we pulled aft the shest, and 'et the boat run down toward him.

The sea was quite smooth; there was just enougb ripple to drown the noise of the boat, and scarcely sufficient breeze to fill our sail. The whale was slowly forging ahead, his hoarse deep. toned spout sounding strangely over the quiet waters. We were over twenty minules making our way to him. In this time. having nothing to do, all eyes were directed to the motions of the fish.

He came blindly on, that part of his head showing above the water, giving one the idea that he had been sawed square off in front. He did not advance in a direct line, but made a number of little alterations in his course, evidently for the purpose of guarding against an enemy in any direction. Every few minutes, too, he would stop altogether, and cautiously lift his head out of water, expressing the action of listening for a noise, just as plainly as it could be expressed. Hearing nothing, he would again advance on his course.

The length of time we consumed in our approach, as well as the extreme caution necessary on such a quiet, calm day, made it a scene and time of great exvitement to us all. We were gradually but surely nearing him. Now the mate raised his hand, a signal to the boatsteerer to seize his iron. We were sitting on our thwarts, 
but in the excitement of the moment, everything was forgotten in watching the motions of the fish. On he came, blindly and unsuspectingly rushing so his death. Wewere already within two boats' lengths of him. - But now he stops suddenly. $\mathrm{He}$ listens a moment, but again proceeds. We think ourselves already fast, when the boatsteerer whispers,

"Let them pull a good stroke-I fancy the whale knows we're here." The mate shook his head; we were almost within dart, and he would not risk it Now he heaves his head out of the water again.

"Heave your iron into him!" shrieks the mate.

The boatsteerer darts his best-but too late.

Even as we looked, and without any motion other than that slight toss of the head, the whale disappeared from our sight.

"That's magic," said one of the boat's crew.

To me, so sudden was the act, it seemed just as though the vast mass had been suspended in space, and the suspensor had been suddenly cut asunder.

Now came the labor of the day. The whale was gallied-that is to say, frightened. He was aware of our presence, but with a perversity com. mon to sperm whales under such circumstances, would not at once abdicate the ground. From the time of his lightning-like disappearanceabout noon -till sunset, our four boats chased him: 
and never at any time, except when he sourded, was he more than three ship's lengths off

His course was a huge circle, many miles in circumference. His speed was just such as to kesp our boats at a safe distance. I could not belp giving the wretched animal credit for gieat intelligence, for the ingenuity with which he kept up the ardor of our pursuit, without permitting himself to be caught. When he sounded, he kept up his usual headway, and on his regular course, so that by pulling as hard as we could for three quarters of an hour, in the hope to get fast the next rising, we would find ourselves, when he reappeared, at just the same distance astern of him that we were when he was last seen. At sunset we were obliged to give up the chase, and returned on board, wearied and hungry. We had afterward several long chases after gallied spermwhales, always without effect, and invariably led by the nose, as it were, by the whales keeping but little ways ahead of the boats, holding out contin. ual hope that we might, in a moment of unwariness on their part, get fast, and gain a prize.

The eastern coast of Madagascar is an unpleasant whaling ground, on account of the constant rains which prevail there. Part of the day is gonerally fine; but seldom an entire day passea without a rain squall, and not unfreque: tly, when cruising near the land, the rain lasts day and night for a week. The weather, withal, is un. comfortably cool, and on shipboard, where $t$ is 
sufficiently difficult to keep dry under the niost favorable circumstances, great discomfort ensues.

But rainy weather is made no account of in a "spouter." If whales are seen, the boats are lowered in the middle of the most violent sq-iall. Sundays and rainy days are no holidays in the whaling service.

When our cruise, however, extended over toward Bourbon and the Isle of France, we had again delightful weather. One day we sighted Bourbon, and sailed close into the land, in order to examine thoroughly for whales. The island is very mountainous, and has, lying as it does in the track of the Trades, a weather and lee side. It was the lee side which we now approached. I never in my life saw a more enchanting country. In the distance were the blue mountain peaks, thrown in uncouth volcanic masses against the sky. In the foreground was a narrow strip of beach, dotted with white houses, peeping forth from umbrageous groves. And rising above these, was the hill side, every inch of which, for miles, was in the highest state of cultivation. Here were the plantations of sugar, coffee, cloves, and tobacco. Each field was bordered by neat rows of coffee trees, betroen which ran the streets. The whole appeared in the most perfect order, and the scene, viewed from a distance of a mile at sea, was enchanting beyond description. It was like the realization of a dream of Arcadie.

The $r$ zader can easily imagine the feelings with 
which we sailed past so beauteous a land without being permitted to place our feet on its shores. For an entire week did we ruise around this delightful isle, never more than five miles from its bold shores. It was a torture fit for Tantalas. And I vowed that let me once get my foot on shore, any where, I would bid good-bye to a service in which such treatment was consideréd legitimate. The balance of our crew were also dissatisfied, and longed to have a run over the beautiful land so long in view. Even the boatsteerers grumbled. But the captain gave us plainly to understand that before we had three hundred barrels of oil on board, we need not expect a run ashore-" and even then," added he, coolly, "you need not expect to go ashore on Bourbon."

Thought I, let me get ashore once, and $I ' l l$ take care of the balance.

On standing over toward Madagascar again, after a fruitless search for whales, we one day fell in with : New London vessel, the James Rodgers, the captain of which proposed to our captain that, as sperm whales seemed to be scarce, and it was iust the season for humpbacking, we should make a j,int expedition to one of the bays in Madagas. car, "Where," said he, "from my former experionce, I know we'll get some fish."

Our captain liked the idea, and it was agreod that we shruld cruise for a week in company, looking for speım whales, and if none wore in 
that time seen, the two vessels should proceed into the bay of Antongil, on the north-east coast of the island, and try for humpbacks.

The James Rodgers had been out a year, and had done tolerably well. She was now just from the coast of New Holland, where they had " hump. backed and sperm-whaled it," so the crew said, "until all hands were worn out."

They seemed to dread the bay whaling. But we, to whom it was something new-no one but our skipper having ever been at it before-thought it rather a good idea-particularly as by its means we should have an occasional run on shore. At the expiration of one week of trial, both vessels were headed to the north, and the crews were informed that we were now bound on a humpback (iruise.

Meantime we were again in the rainy climate. Every day it rained. For days the sky is leaden and gloomy, the clouds being apparently sureharged with rain. The winds, too, are shifting and squally, while water-spouts are constantly in sight. Little harmless eddywinds, which cause the spouts, may be seen starting up and sailing along in all directions. Sometimes the ship is beset with them; the foresails get the benefit of one breeze, while the after sails are filled with a quite different and contrary one. On the forecastle a torrent of rain will be falling, while the quarter-deck and poop are perfectly dry; and nometimes, the toj-gallant-sails will be filled with 
a strong breeze, while not a breath stirs the lower sails. The nights are dark as Erebus, even the full moon being able to send only occasionally a fitful gleam through the dull opaque clouds. The days are gloomy and dispiriting, being made up of alternate squalls of rain and wind. Such is the eastern coast of Madagascar-a most uninviting cruising ground.

It was while making our way toward Antongil Bay that, on one dark, gloomy day, the captain sent several men aloft, to look out for shoals. He was himself, at the same time, continually starting into the rigging, and peering anxiously about with his spy-glass. We did not judge ourselves near the land, and had therefore some curiosity to learn whether any shoals could be seen.

"It seems to me that there are some breakers on the lee bow, but I can see nothing for the sea to break against," sung out the mate, who had been sent aloft to look out.

"That's it-where away on the lee bow is the surf?"

"A.bout four points."

The vessel was kept away a little, and as there was quite a breeze, we were soon able to see from the deck a long line of white, where the sea broke upon the edge of a huge sand-bank.

The bank itself, owing to its color, we could not see till we were closer in. It was a dreary and wo-begone place, and a sight of it prepared me to appreciate the tale of horrible cruelty which is con. 
nected with it. The bank is about two miles long, by half a mile wide, and apparently lies just above the water's edge. With a stiff top gallant breeze, sucl as we had, the surf did not break entirely over it, but it would have required but a slight increase of wind to force the breakers over the shallow barriers. The low, dull roar of the surf seemed a funeral dirge over the graves of many poor fellows who have here struggled for the last time with death. Not a tree or shrub, not even a blade of grass, could be seen on the entire bank; nothing but sand and breakers.

As I thought how easily, even in broad daylight, a vessel might run upon this hidden danger, lying, as it does, just in the track of ships bound to some of the ports of Madagascar, and as I thought further how hopeless would be the fate of those who should be shipwrecked here, an inward prayer arose that such might never be my fate.

"That's a bad place to get on," said the old man to me.

"Yes, sir."

"There's a story told of this St. Mary's shoal, as it is called, that makes me shudder every time I see the cursed place. Some ten or a dozen years ago, slavers used occasionally to get a cargo on this east coast, all the vigilance of the French and English cruisers to the contrary notwithstanding. There was then a slave factory at Nos Beh, (now a French settlement on the northern extremity of 
Madagascar). A ship having on board seven hun. rred poor slaves, in making her way from Nos Beh to the southward, got upon this shoal. It was happily in the day time, and although the ressel was wrecked, they had time to release the poor blacks, and with their help to catch a supply of provisions and water from the various articles which floated ashore from the wreck. They built themselves rude huts upon the highest part of the bank, and here remained, waiting for a passing vessel.

"Day after day, however, passed away and no succoring ship hove in sight; and they saw with dismay their supply of provisions, and particularly their water, getting low. In this emergency, a new thought entered the minds of the whites. On the adjoining coast of Madagasear, at a distance of about seventy-five or one hundred miles, is located the French settlement and fort of St. Mary's. They could make a small raft of the portions of their ship which had drifted ashore, and with this steer to the mainland, taking advantage of a favorable breeze.

"To procure the assent and aid of their black rictims to this plan, they promised them most solemnly to send a vessel to their help immediately on their arrival in St. Mary's. But, scoundrels as they were, the thought had already struck them that by informing the French authorities of the presence, upon the shoals, of these slaves, they would get themselves into trouble : 
and so they concluded to make their own way safely, and leave the blacks to their fate.

"The raft, after infinite trouble, was built. A large share of the remaining water and provis ions were placed on it, that th 3 whites might be sure to reach the shore, and then, bidding the poor slaves "good-by," and assuring them of their speedy return with aid, they spread a sail to the breeze, and were soon out of sight. What long days of agonized expectation the poor blacks passed upon that bleak shoal; how, gradually, as it were hour by hour, hope died from their breasts ; how, as their little remnant of provisions failed, they began to die off, and how the survivors, brought to the last extremity of suffering, were obliged to subsist upon their deceased friends; how anxiously they peered across the wild waste of water which surrounded and threatened to engulf them, and how each sun rose upon a frest accumulation of the dead and dying-all this was told by the one lone survivor of six hundred who had landed upon the bank. A St. Mary's coaster passing by the shoal, saw upon it some signs of a wreck, and approaching searer, was able to discover the forms of men lying about upon the sand. Effecting a landing at the risk of their lives, they found but one poor Madagassy le:? alire, and took him with them. It was found, afterward, that the wretches of the raft, fearful that mention of their companions in misfortune would get them into a French prison, told a story 
ef having been in a leaky vessel, and abandoned her at sea, and stated that they were the last rem. nant of the sufferers.

As the captain told me this story, the long, low woal was just astern of us, the surf was still booming in our ears, and a shudder of horror ran through me at such wanton barbarity and hesrt. เอสล selfish ness. 


\section{CHAPTER X.}

Domerting furtner concerning the habits of Whales - Tbs Humpback - Their liability to Sink when dead-Antongil Bay-Our Anchorage-The denizens of the Jungle-Our first Whaling day-A Word concerning the Weather-Actions of Whales-Close of the first Day-The Night-Another Del. uge-We get fast-The Whale spouts Blood-Tenacity of Life-Towing a dead Whale - Cutting-in-Trying out-A "Cow and a Calf"--Strong affection of the Mother-WhaleHow Whalemen take advantage of this-The Calf is killedThe Sharks eat up our Whale-Scaring a Humpback-Its Results.

A Few days after seeing the St. Mary's shoal, and hearing its story as related in the last chapter, we sailed into Antongil bay. This is a large inlet on the east coast of the island of Madagascar, in about latitude $16^{\circ}$ south, and longitude $50^{\circ}$ east. It is over fifty miles deep, and about twenty-five miles wide at the mouth. At the bottom of this extensive bay, and under lee of a small island, our two ships were brought to anchor, and here it was determined we should remain at least : morth, to try for humpbacks.

The females of these whales, as well as of the right whale, frequent bays and shallow waters yearly, when their time of calving comes on, to drop their young, remaining in the smooth water. 
antil the young leviathan has gained strength sufficient to shift for himself on the broad ocean. These ocuasions are taken advantage of by whalemen, and great numbers of the old fish are slain annually in the many unfrequented bays of Africa and South America.

Whalemen assert that the sperm whale mother also approaches the land to give birth to her young, but her haunts have, I believe, never been discovered, and this is, therefore, more a probability gathered from analogy, than an ascertained fact. The right whale mother is very careful to choose a retired and unfrequented roadstead for the scene of her maternal labors, and bays on the eastern coast of Africa which were formerly noted as the annual resort of great numbers of these animals, have been altogether deserted by them shortly after the whalemen got among them. The humpback, however, the most stupid of whales, clings obstinately to the place it has once chosen, and thus numbers of these fish are annually taken in the great bays of New Holland, Madagascar and Africa:

When this species of whale is met with at sea, it is seldom thought worth lowering after, for the reason that it is exceedingly hard to kill, runs 10 windward at great speed on being struck, and generally sinks when killed. When a dead fish sinks at sea (and this sometimes occurs with right whales as well as hump backs), he is of course lost. In soundings however, the case is different. 
The whale is anchored, and a large buoy is left to mark his place under water. The progress of decay evolves certain gasses in his body, which being. lighter than the water, raise the body to the surface; and once there, it is again taken pussession of by its captors.

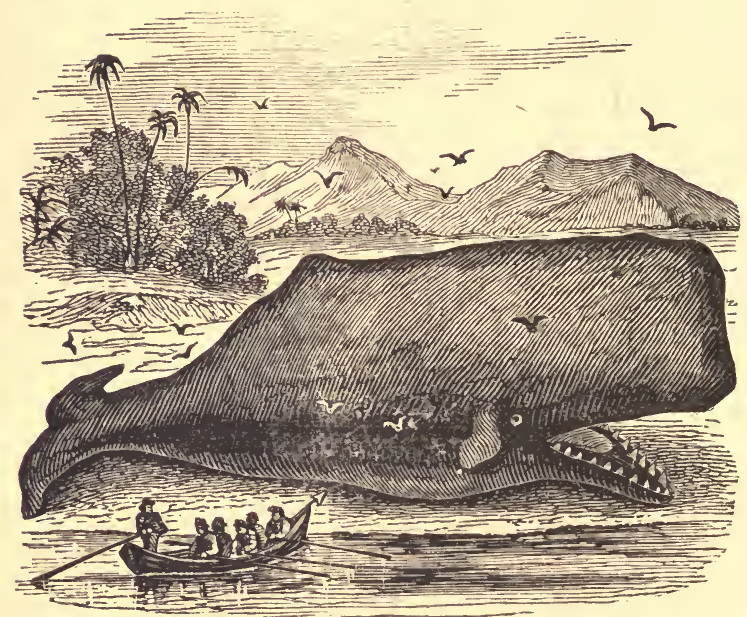

A I F R M W HALE.

As in the bays of tropical countries the strong sea breeze generally alternates with a mild and genial land breeze, the humpback in running to windward does not so often get beyond reach of his pursuers, and although hard to kill, generally falls a prey to a good whaleman, when struck during the prevalence of the land wind.

As we sailed down the great bay, the waters 
seenred alive with whales. It was evidently the hight of the season, and we congratulated ourselves in advance, upon the havoc we should make among the fish At the bottom of the bay was a small island, about three miles in circumference. in a sheltered nook on the lee side of this island, we brought our ships to anchor, under the direction of the captain of the James Rodgers, who had been here before. Having safely moored the vessels, we unbent the light sails, and made other preparations for a lengthy stay.

Having fixed upon a convenient landing place on the shore, we rolled up our empty water casks, to be filled before going away. Hire too, a tent was erected, in which the armorer and carpenter could work, and under shelter of which the crew could rest when ashore.

The island, which consisted of a high mountain, bordered by a narrow strip of beach, was covered from the waterside up with a dense mass of trees and undergrowth, forming an impenetrable jungle. This jungle, so said the captain of the James Rodgers, was inhabited by a few wild cats, or leopards, and numerous monkeys and flying foxes. It was infested likewise, as we afterward found, with great numbers of serpents of various kinds, but chiefly by a species of anaconda, some of which, that we killed, were fourteen feet long.

On the day after our arrival, our whaling duties began. We were called out at half past four o'clock in the morning. The cook having beep 
roused at four, had our breakfast in readiness, and after devoting fifteen minutes to this, "lower away" was shouted, and all hands were immedi. ately called into the boats. It was 's course not yet daylight, but we at once stood for the lower part of the bay, which being with the morning land breeze the extreme windward, was the scene of our primary operations.

After pulling away about three quarters of an nour we began to hear whales-some breaching, some making the white-water fly, others under headway, and spouting with a loud metallic soand very closely resembling the puffing of a Mississipp steamboat. It was not yet quite daylight. The rain-it had rained ever since we lowered-was pouring down in torrents, the air was chilly, and when not pulling, we sat shivering in the boat, the water running from our clothes, much as though we had been standing under a Brobdig nagian shower-bath.

At six o'clock it was fairly light enough to work. Un taking a survey of the ground, wo found ourselves at the entrance to a little bight of the shore, about a mile deep, at the bottom of which some whales were seen disporting them. selves in the rain, which they evidently enjoyed. It had been arranged that our eight boats, (the Jas. Rodgers was a four-boat ship), should cruise in parties of two. Our partner was the third mate of the Rodgers. Hailing him, a short con sultation was held, the result of which was 
determination to pull intc the bight, and try the fish we there saw. The other boats, meanwhile, were posted on different parts of the ground, each twc choosing for themselves a special portion, and paying exclusive attention to the whales thuy found there.

We spent the entire forenoon in a fruitless chase of the humpbacks, who seemed to dodge the boats with the utmost ease, and while apparently not attending at all to our movements, took care never to come within dart of our irons.

They had none of the regularity of the sperm whale, and their motions, unlike his, could not bo counted upon. The land breeze was very weak, for which reason we were obliged to use the oars, and substitute what whalemen call a "white ash breeze," (in allusion to our oars being generally made of that kind of wood), for the natural air.

About twelve o'clock we took a little rest and ate our dinners, consisting of sundry biscuits, interlaid with pieces of salt junk. Up to this time none of the boats had succeeded in getting fast, much to our disappointment; for when on the previous day we saw how numerous were the whales, we had imagined it to be hencoforth an easy and every-day matter to kill them. Shortly after dinner the sea-breeze set in. At the first puff the whales were thrown into the greatest excitement, and snorting louder than ever, started for the mouth of the bay.

We could now use our sails, and made haste to 
put them up. With the breeze came in a very disagreeable chop sea, which made pulling straight to windward except for short distances, almost impossible. It was therefore necessary to beat to windward under sail, and thus try to head off the whales. In this we did not succeed-nor was any one of the boats that day so fortunate as $t$ s set within dart of a whale.

The rain ceased at about eleven o'clock, A. M., and the sea-breeze, clear and bracing, soon dried our bodies and our clothes, so that by the time wo returned on board, at four o'clock, no change of dress was necessary. After our return, we took a short run on shore, killing within fifteen minutes after landing, three serpents, each over eleven feet long. They lay at the edge of the woods, coiled up neatly, and apparently stupefied. They made no resistance, but displayed the usual snakeike tenacity of life.

Supper at five and bed at six, finished one of the most disagreeable and unsatisfactory days we had passed on the voyage.

Meantime the officers held a council, and arranged the programme for the morrow, which differed, however, in nothing from that of the day past, but that we should go closer in shore, as it was there the cow whales would most probably be found with their young. Orders were at the same time given, not to fasten to a bull whale until the sca-breeze set in, when, as the fortunes of the day would by that time be pretty well 
decided, any one was at liberty to strike what he could get on to. This restriction was rendered necessary by the fact the male humpback invariably runs on being struck, and moreover, turns out for his size a much smaller quantity of oil than the female.

I fell asleep, earnestly hoping that it would rair no more while we remained here, and anticipating. from the beautiful starlit and cloudless sky with which I had regaled my eyes before going below, that to-morrow, at any rate, would be a fine day. At ten o'clock-four bells in the first watch-J was called out to take an anchor watch, and on proceeding to the deck, found the sky of a leaden color, not a star visible, and everything looking as though "the great rain" was about to set in. At eleven o'clock, the skies opened, and it began to pour down in such sheets and masses as can only be witnessed in the tropics; and thus it continued without intermission until eleren o'clock the noxt day, when the sea-breeze set in, the sky became clear, the air once more bracing, the sun shone out cheerily, and nature resumed her Sunday look.

At five A. M., when we lowered, the rain was pouring down in such torrents that one mar was ohliged continually to bail rain water out of the boat; while we could not see two ship's lengthe ahead through the sheets of water. Tho yesterday's maneurers - pulling to the bottorn of the bay, therc sa.ling about when the breeze would 
favor us, making vain attempts upon whales, wnc only spouted at us, as it were, in scorn, and finally striking out for the outer bay, as with the strengthening sea-breeze the whales made off in that direction-all these motions were repeated, but again $w^{*}$ thout success. Not a boat had the good fortune to get fast, and we returned on board, at four o'clock, much dispirited, and wearied with fruitless toil. After going on shore, trying to kill a monkey, of which animals however but few showed themselves near the beach, and killing two more snakes, one fourteen feet in length, we ate supper, and with every promise of a beautiful day on the morrow, deposited our tired bodies in the berths.

These two days were fair samples of the duty we performed during our stay here of over a month. Every morning, without a single exception, it rained in torrents; and every morning. without a single exception-("no Sundays in ten fathom of water," say whalemen)-precisely at five o'clock we started out and chased whales until the sea breeze became too strong, or the whales" had all disappeared to windward.

We took six whales during our stay, nne of which was completely eaten by ground sharks, with which the bay seemed at times alive.

It was on the fourth day after our arrival, that sur boat got upon the track of a whale who seemed disinclined to get out of our way. He had dodged us for half a dozen risings, coming up 
in unexpested places, and lying quite still till we were almost upon him, when suddenly he would disappear, only to show himself perhaps in the very spot from which he had before started. The uate at last, wearied with chasing him, concluded Ir remain quite still and notice his maneuvcrs For several risings we watched him very closely, and at last, with his suspicions apparently lulled, he came to the surface not half a dozen boat's lengths off.

To lay the boat around and pull for him, might and main, was the work of but a few minutes. We were upon him before he was aware of our presence, and with a loud hurrah, the boatsteerer planted an iron in his back.

No sooner were we fast, than three other boats, which had been cruising in the vicinity, came to our aid. The whale, after sounding-an operation wlich did not amount to much in ten fathoms water, ran a little ways, and then stopped, evidently at fault, and snuffing for the breeze. Now he would dart in this direction, now in that, now north, now south, now east, then west. But it was just then a complete calm, and he made no headway.

Of course we took advantage of his motions to ply our lances, and in a very short time had the satisfaction to see him spout blood.

N.w when a sperm whale spouts blood, it is an evidence that death is at his door But we were to learn that day that a humpback does not 
die so easily. The sea-breeze set in just as the whale began spouting what we thought to be thick blood. With the first puff of wind he seemed to revive, and gathering new energy, darted off seaward, at the rate of six or seven miles per hour, dragging with him of course our four boats.

We now experienced another peculiar trick of the humpback. A sperm whale will sometimes run under water, but has at any rate the merit of keeping straight on his course. Our prize, as he proved after a long-continued effort at escape, would spout once, then turn flukes and run along the bottom, till it became necessary again to breathe. Then another spout, another toss of his flukes high in the air, as though the water had been a mile deep and he were bound to touch bot tom, and another race along that bottom.

This course was continued till repeated lanc. ings and great loss of blood had exhausted him. Of course, his short stay at the surface made it extremely difficult to lance him properly. We were compelled to haul so close to him that when he turned flukes, the broad tail often grazed the boat's bows. Had-it been a sperm whale, this would have been exceedingly dangerous play, but our humpback plainly thought of nothing but running. For an hour he kept up his first speed. By that time, however, he was tiring, and his pace moderated.

Now two boats would work upon him at nnce, 
and sometimes the officers could set their lances into his body. Clotted blood and pieces of liver and lungs were now spouted up continually, yet the sbstinate beast retained strength to drag us through the water. Four hours, from ten till wwo, we worked upon him, and when, at two o'clock, he finally expired, he was actually under neadway. We were lancing him, when ho gave a little start and suddenly turned over, heaving his long fin out of water, and with a slight quiver died. By this time we were nearly twenty miles from the anchorage, and had now before us the disagreeable task of towing our whale to the vessel. After waiting a short time, to see if he would sink (which in this case did not happen), lines were fastened to various parts of his body, and we began towing him landward.

"Why don't you tow him tail first," I asked of one of the boatsteerers, "that seems to be the smallest end."

"That plan has been tried, but was not found to answer so well. He seems to have been designed to go head first, and that is the easiest way to tow him."

We were shortly joined by the other boats, and were then able to make headway at the rate of about three miles per hour, with the aid of a stiff sea-breeze. Do what we would, however, we could not keep our whale heading as we wished. His body seemed to fit naturally in the trough of the little sea that was on, and thus he lay, spite of 
our most strenuous efforts. We were obliged to tow him sideways for nearly the entire distance.

It was one of the most tedious and straining undertakings I have ever assisted at. Hour after hour we tugged at the oars, our progress so slow that we scarce seemed to gain any. My heart gank as I thought that every whale we took would have to be brought alongside in just this way.

It was eleven o'clock that night ere we had our whale moored alongside. I was never more ex hausted in my life. Some of the hands were downright sick. The following day six boats' crews remained to cut in, while our captain, leaving the fourth mate on board, went down in company with the captain of the Jas. Rogers, to try his fortune. They returned empty-handed, just in time to see the last blanket-piece going into our blubber room.

The operations of cutting in and trying out are of course much better and easier done in harbor than at sea. All the labor is lightened by the steadiness of the ship, and there is at least a bare possibility of keeping clean. Two boats' crews were left on board the following day to try out the rest of us going off as usual at five o'clock, in the rain.

We, of the mate's boats' crew, were quite proud of having gotten the first whale in the bay, and determined to distinguish ourselves again if pose sible. But on that day the fates favored the sec. ond mate of the other vessel. Sailing close in to 


\section{A DOW AND CALF.}

shore in the lower part of the bay, he saw a cow and calf, and pursued them. The cow whale could easily have gotten away, but would not leave her little one. She tried every expedient to quicken its progress, first bearing it on her flukes, then taking the little thing between her fin and body, and when she found this useless, placing it before her to push it along with her nose.

But all was vain. The mate pulled up, and by way of making sure of the mother, who had just gone down, put an iron into the calf.

Soon as the mother came up, she was fastened too, and in a few minutes was spouting thick blood. By this time we were upon the spot, ready to render assistance.

The mother whale seemed solicitous only about her calf. She would fondle it with her huge snout, and push it along before her. She would get between it and the boats, to keep it out of harm's way. She would take it down with her, knowing that on the bottom was the safest place. But here the little one could not obey her. It was forced to come up to breathe at least once every two minutes, and by this means, even had we not been able to tell by the strain of our lines, we knew at all times where away was the old whale.

Never did mother, of whatever species, display a more absorbing affection for her young than did this whale, and there was scarcely one in the pur. suit, but felt as though we were taking a dishonora ble advantage of her. 
It was soon discovered that we could urge the little calf in any direction, by gentle touches of the lance, and accordingly we forcea it and its mother with it, to take a course leading toward the ships. For two hours we continued lancing her, and as she spouted blood nearly all this time, we were satisfied she must soor die.

But now-we were scarce half a mile from une vessels-the sea-breeze came in, and as she felt it, new life seemed to enter the whale. She again tried to push her young one ahead, and finding this useless, and that we took occasion meantime to ply her with lances, she suddenly turned upon the boats.

- Six boats were now gathered about her. When a boat would approach her, she would whirl round and dash at it with her flukes. With her long sword-like fins (a sixty barrel humpback's fins are at least twenty-five feet long, and shaped like a broadsword), she kept us off her sides; and by running continually around in a small circle, she got uur various lines so fouled that we began to fear we should have to cut from her and fasten afresh.

The sea, too, was getting very high, and it was disagreeable to work about a whale. At this time one of the boats pulled up to try a lance. It was a long dart, and instead of striking the whale, the lance glided into the little calf, which was lying snugly along her side.

With a weak puff the calf turned over ara 
sank. The mother seemed to know in a moment what had happened. She followed it to the bottom. After making several circuits about it, as we guessed by the motions of our lines, she again rnse to the surface, but this time with nose pointed to the windward.

"Now we'll have to take it, Charley," said the boatsteerer to me.

And sure enough, she dragged us off against the wind, and through a most uncomfortable sea, at the rate of four or five miles per hour.

It was sunset before she brought to again, and then we were eleven or twelve miles from the ship. The wind was very strong, but fortunately for us, she had dragged us under the lee of a small headland, and the sea was not so violent.

Here she stood at bay. But there were so many boats, that while some would engage her attention and her flukes, with which she defended herself, others would approach from ahead and lance her. With all this, however, it was long after sunset before she finally "rolled fin out."

We could not of course tow her down that night, and as one of the boats had a small kedge stowed in the bows, the whale was brought to anchor: First we put irons into various parts of her body, with which to lift her in case she sank. Next, the anchor was dropped, and a small cable made fast to the whale's flukes, and finally, anchor and whale were buoye $d$ with a Arug.

It was ten o'clock ere we got on board this night, 
and the way from the whale to the ships wae very unpleasant, the night being as dark as pitck, and the sea very high. T'he following morning all the boats were mustered together, and we pulled for our whale. Arrived upon the spot, which we easily recognized by the bearings of the land, we found no buoy. The whale we had hardly expected to find-knowing she would sink. After a search of an hour, we found our drug, and taking from it the lines, disposed ourselves in the boats so as to weigh the whale.

It has been found that if, where a whale has sunk, sufficient force can be brought to bear upon him, to start his body from the bottom, it will continue to ascend, and when it once gains the surface, will not again sink.

"If we don't lift our whale, the ground sharks will eat her," was the captain's reason for haste.

The first tug we gave at the lines brought every iron up from the bottom. Some had pieces of the entrails, others patches of the blubber adhering to the barbs, and it became at once evident that the sharks had been beforehand with us, and had eaten off the outside, of blubber, before we arrived. With many a muttered curse, "not loud but deep," we gathered up our lines, anchor and drug, and departed.

During the week following this loss, we captured two whales, both cows with calves, and both made prey by taking advantage of their strong affections for their young. Care was taken after this how. 
over, not to kill the young calves, "'as it was a aseles waste of life," so said the mate of the Rodgers, "and besides had a tendency to exsite the cow whale."

I thought it would have been the part of mercy to kill the calves after dispatching the mother, inasmuch as they were not yet old enough to get their own living, and would most likely starve to death.

As we were pulling about in the lower bay one morning, a great white-watering attracted our attention. Some suggested that two whales were fighting, others that a school were enjoying themselves. But on approaching the object of our curiosity we found it to be a little bull humpback, one of those inveterate runners whom we scarce ever cared to attack, endeavoring to drive off one of the calves whose dam we had killed several days before. The little thing had become half starved, and was endeavoring to find the wherewithal to satisfy its hunger. As it approached the whale, he would wheel round and strike at it with his flukes, sometimes hitting, but oftener missing it. His short loud spouts showed clearly that he was in some consternation, and did not quite understand the maneuvers of his troubler.

The captair of the James Rodgers, who was an old hand at humpbacking, had informed us that when chasing a bull humpback, if we could get so close upon him as that he could not turn flukes, we could easily get fast, as then he would 
remain at the surface; and further that $x$ such times by hallooing, hooting, beating tin pans and blowing fog-horns, the whale woudd become so terrified as to be unable to move. We had one opportunity to put this to trial, but met with a spe zies of success which discouraged any farther attempts of this kind upon the fish.

We had started two whales from under the land, and for several hours were pulling after them, with some hopes of catching up with them, as they seemed to go off in a straight line, and at no greater speed than we could ourselves make by strenuous exertions. We were alone, our partner boat having gone off in chase of another whale. The whales slacked their speed a little, and encouraged by this, we rushed the boat upon them, shouting and hallooing at the top of our voices, the mate bringing into requisition a conch shell of formidable dimensions, from which he blew a most ominous toot-toot.

One whale made his escape, but the other berame in a manner paralyzed from fright, and lay still upon the water, moving his great flukes slowly up and down, but making no headway.

"Strnd up, you sir, and don't you miss that whale," shouted by the mate apprized us that we were upon him.

"Give it to him!" and at the word Barnard, who to use the mate's language, "would have struck the whale had he been sure he would have struck him back the next minute," darted his irc 
and win with the same motion leaped over. board.

If the whale was before paralyzed with terror, the first touch of the iron gave back to him all $\mathrm{k}$ is powers, and quick as a flash an immense pair of flukes carne down on the boat's bow, cutting off about three feet of it nearly as smoothly as though it had been sawed off.

Had the boatsteerer not jumped overbuard, he would have been instantly killed. I, who sat next him, was thrown overboard by the shock, the boat filled; and had not the iron fortunately drawn, we should have been in a mess of trouble.

As it was, all hands quickly got into the stern, by which means the boat's bow was raised out of the water; and thus we were able to paddle sternforemost to the ship, a distance of over two miles.

That was the last time we tried the plan of scaring a humpback. Had there been time for the exercise of a litte prudence, we could have gone on easily without being stove. But our boatheader ras an excitable man, and at this time as on a fr.rmer occasion, lost all command orer himself and rushed the $b$ sat to certain destruction. 


\section{CHAPTER XI.}

Axтonart BAy, continued-Whaling near Desolation Islarat. Teddy-A Character-Sea-Lions-How they are CapturedT'annanarivou-A City on a hill top-The Natives-The Scurvy-Burying a Man-Nearly a Ghost Story-The Cook's opinion of Ghosts - Attempts at explanation, meet with nn Favor-The Result-Preparing to leave the Bay-Our first and only Holiday in the Bay-A Tour of Exploration-Disturbing an Ant's nest-Flying Foxes-We proceed to Sea.

To relieve the monotony of our rather dreary life in the bay, we frequently visited each other's vessels. I found much to amuse me on board the James Rodgers. They had been three years from home, cruising during that time mainly on the coasts of Ceylon and New Holland, and had some singular adventures to relate. One of the crew, moreover, had made a voyage to the Isle of Desolation, a place of great resort for sea-lions and seals, as well as right whales, and as he had ? wonderful facility in spinning yarns, and was, w: hal, obliging enough to talk for us by the hour, several of our own crew spent all our-leisure time on board the Rodgers.

Teddy, so ht was called, was a genuine Yarkeo boy; and about is ugly and good natured a speci. 
men of mortality as one could expect to meet with in so out of the way a place as a whale ship. Ho was the self-constituted hero of numberless adven. tures, which he could impart in a manner entiroly his own, never thinking of concealing porsonal defects, and laughing as heartily at his own mis. haps as those of any one else.

Teddy had served an apprenticeship to whaling in the cold regions of Desolation, and was not, therefore, remarkable for personal cleanliness or neatness. He gave it as his deliberate opinion, that too much washing was deleterious to the health, besides involving an unnecessary waste of time. His clothes, which were patched even beyond the mark of whalemen in general, presented a variety of hues which reminded one of Joseph's coat of many colors; they fitted him with a studied awkwardness which could not fail to attract attention from the most casual observer, and excited in me most unbounded admiration.

With his ill-fitting and well-patched shirt, his scraggy head of fiery red hair overhanging his face, and thin whiskers of the same color, which he was used to say required a drum and fife to marshal them together, Teddy put one very mucb in mind of the little rough-haired Scotch terrier, so famous as ratters. So striking was this resem. olance, that I was led one day to ask him if he had ever followed the business of rat-catebing. With a huge grin, such as only Teddy cculd 
assurne, he answered, no: that there was not onough oil to be gotten out of a rat to make such a business pay.

Desclation, or Kerguelen's Land, by which last nurre it is most generally known, is an island in the Indian ocean, in about latitude $49^{\circ} 30^{\prime}$ south, and longitude $70^{\circ} 10^{\prime}$ east. It is a sterile, dreary spot, uninhabited, save by seals, sea-lions, and penguins. It lies entirely out of the track of merchant vessels, and is little visited even by whaleships, the ship in which Teddy had made a voyage thither being one of but two or three that had at that time made it their exclusive headquarters for a year or two at a time.

From Teddy's yarns, I gathered that all the various species of seals abound there at certain seasons of the year, and that right whales had found here likewise a retreat in which they were comparatively little disturbed.

It appears that on her arrival at the island, the vessel was securely anchored in a snug harbor on its leeward side. All the empty casks, and a great proportion of the stores, were now landed, and placed in huts constructed for the purpose. 'Try. works were also set up on shore, and all the operations of killing, skinning and trying-out were reudered thus as little laborious as possible. 'Tho sea-lions at regular intervals during the day uscended the crags and steeps with which the whore was lined for miles around, and wero on 
these occasions attacked and slain in great num. vers. The weapon of attack was a stout lance fixed to a short hickory pole.

At early daylight, said Teddy, the labor of villing cask and cleaning fur-seal skins begar. About nine o'clock the boating parties were started off for the appointed scene of labor. They pulled or sailed along shore until they discovered the seals, then moored their boats, and dividing ther. selves in parties of two, proceeded to the slaughter, which it was necessary to accomplish as silently as possible.

Teddy confessed that the first time he approached an old lion, for the purpose of lancing him, he was in great bodily fear.

"As I approached," said he, " the beast gave an awful roar, and lifting up its ugly head, snapped viciously with its jaws, plainly showing mo that if I got into its clutches once, it would go hard with me. I had received due caution against approaching it from beneath, as in such cases the animals are wise enough to roll over on their attacker, and thus overcome him.

" "There was, however, no time for considera. tion. My lion was before me, and the mate was watching me from a distance, to see that I sul. fered no damage. So I ran up, man fashion, and plunged my lance into his breast, just as he was preparing to roll over the rocks into the sea. Luskily, the first stab settled him, and with 
loud hurrah of suddenly gained confidenco in my swn abilities, I jumped on to attack another."

After killing as many as they could carry off that das the work of skinning and lugging the blubber ined hide to the boats began. Here two worked together. As the beasts were duly divested of their hides, a hole was cut in the center of each. A hide being now lifted up, one's head was inserted through the opening, the mass of. blubber hanging about him something after the fashion of a Spaniard's poncho. In this guise, with the filthy oil dripping from every pore, he now scrambled over rocks and declivities, down to the boat, in which the load was deposited, while the bearer returned to repeat the operation. It was in this business that Teddy had contracted his aversion to water, taken externally, as a purifier.

"As an internal remedy," said he, one day, in discussing its merits, "a very little water, mixed with good whisky, is not at all objectionable."

Of relating his mishaps with sea-lions, Teddy never tired, and, to own the truth, neither did his auditory ever tire of him. There might have been more intellectual amusement, but under the cir cumstances, there could have been none provided of a more enlivening nature.

When we first entered Antongil Bay, all hands congratulated themselves in advance upon the oleasure of an ocrasional ramble ashore, never 
imagining that there could be such a totally inac. cessible place as prored the island under lee of which we were moored. When a ramble through the thick jung.e of the island was found -impracticable from the impenetrability of the woods, as well as dangerous from the exceeding abundan 20 of serpents, of which we killed some every day, although never advancing inland beyond the immediate beach, we began to cast longing eyes upon the shores which we every morning approached in pursuit of whales.

In the far distance, at the top of a high hill, we could discern a city, seemingly, of considerable dimensions, while in the vicinity of the beach at various points, herds of the large hump-cattle of Madagascar grazed. Here, thought we, must certainly be a fine country; and I know not what wild plans flitted through my brain, of clandestinely leaving the vessel, and taking up my abode. with the natives for a time.

All these ideas were, however, scattered to the winds by the unmistakeable enmity exhibited toward us by the natives, upon an attempt on nur part to effect a landing upon the mainland. It was from the first apparent that we were watched right jealously, parties of the natives, spear in hand, often following for ho irs any of the boats that chanced to be cruising near the land. We had not tasted fresh beef since leaving home, and although warned by the officers of our partner shıp that we would be unsuccessful in any attempt 
to purchase some, our captain and mate ono day boldly steered for the shore, at a point which seemed like a good landing, determined to hold soune kind of parley with the natives. Quite a number of these were gathered together, awaitir $\boldsymbol{k}$ ır approach.

As we got within hailing distance, one, evidently an officer, for he had on the tattered remains of an officer's dress coat, the epaulettes being the most conspicuous object about him, asked in broken French what we desired.

The mate, who spoke French, answered in that language, stating that we desired to obtain a bullock, that we had some articles of trade in the boat, and that our captain would be pleased to open regular communications with the natives, and purchase of them such articles of food as they chose to sell.

He was answered by a warning that if ever we touched the shore, we would be massacred; and that the Queeu of the island had sent strict orders to the coast, that no communication whatever should be held with strangers. No trade could therefore be permitted, and he advised us to be careful how we approached the shore, as the Mad. agassy were bent upon showing no mercy to such unfortunates as fell into their hands.

Thus were all our hopes of fresh beef and a rur ashore at once disappointed.

As yet there were not among our crew any signs of scurvy. In fact, we had been but a short 
tinc without potatoes, the greatest anti-scos butic, the supply we obtained at Tristan de Acunha. having with proper management lasted us till we cr.tered Antongil Bay. But of the crew of the Jas. Rodgers, several were beginning to exhibit evidenres of the disease, in their swollen limbs and dilatory movements, and one poor fellow was already confined to his berth.

When it was found that there was no hope of obtaining fresh provisions from the shore, it was determined to bury this man, a mode of cure which is practiced only in extreme cases, but which gen erally proves successful - having this disadvantage, however, that where it does not cure, it kills.

A little shed was built on shore, beneath which a hole was dug in the ground sufficiently large to contain the sick man in a sitting posture. In this he was placed about ten o'clock one morning; when the rains had ceased unusually early. The ground was then loosely thrown about him, until he was covered up, leaving nothing but the head exposed. He remained here until sunset, when he was taken out and conveyed to his berth on board, in a state of great exhaustion. In a few days he regained strength sufficient to walk about decks, a d by dint of care in matters of diet, he was in a few weeks able to return to his duty. Not however, without bearing about him the marlss of the disease, in several bunch-like gath. orings of the muscles on his legs and thighs, known among snamen as scurvy.marks. 
It was but a few days before we left the bay; that a singular incident occurred, which, had the succeeding circumstances been only more favora. ble, would have given rise to a veritable and most andeniable ghost-story. Many such, I dare say, rest on a less plausible foundation.

The humpback is in many regards a fish of very singular habits, differing in great measure from those of any other species of the whale. Among his oddities is one which those of us who daily labored in the boats had soon gotten used to, but of which the ship-keepers knew nothing. A whale would sometimes get under the boat, at such a depth below the surface that the crew were entirely unaware of his presence, and there utter the most doleful groans, interspersed with a gurgling sound such as a drowning man may be supposed to make. The first time I heard these sounds it was almost incomprehensible to me that they could proceed from a whale. But close watching of their motions convinced us all that they were the true authors.

So little noteworthy had the matter been thought after its cause was explained, that it was. not a topic of conversation on board, and so it came about that our ship-keepers were left in entire ignorance of the imitative powers of the hum I. back.

One morning about eleven o'clock, when the buats were all on the daily cruise, and but half a dozen men on board each ship, our steward 
bappened into the forecastle, and was there startled by a most unearthly groan. Thinking that his ears were deceived, he listened intently for its repetition, and was soon gratified. A nioan as of one in terrible agony, he said, issued from the berth of the present writer. Two jumps carried him safely to the deck, where he at once informed the cook of what he had heard, declaring his firm belief that the ship was haunted.

The cook laughed at the to him funny idea, and thought a ghost must have but poor taste, to come into this outlandish part of the world. The stew. ard, however, related his story to the ship-keepers, and asked them, to make assurance doubly sure, to step into the forecastle in person, and regale their ears with the mysterious noise. Accordingly, all hands (only three, the other three being at work ashore), descended to the haunted region.

They had scarcely entered, when the groans were repeated with even more horrible emphasis than before. With hair erect, and elongated faces, they listened sufficiently long to vouch that the dread sounds proceeded from no where else but ra; berth; and then, overcome with terror, rushed to he deck, seized the jolly boat, and took refuge on board our partner ship.

The black cook alone remained on board. $\mathrm{He}$ scorned to run from anything that could only groan, and having satisfied himself that there was no tangible cause for the noises, in or about my berth, quietly busied himself about his gal'ey 
thinking, as he remarked to me afterward, that "if it was really a ghost, and it did the poor thing any gond to groan, he had not the slightest objection."

In a short time the sounds could be heard upon deck, and then they gradually died away, until presently quiet was restored, and the affrighted fugitives returned to the vessel.

"It is a ghost or spirit, that's certain," asseverated the steward, who had told the captain of it, already before the latter got out of his boat.

"If you talk to me of ghosts again, stupid, J'll put your head in a bucket of water," was the reply.

This threat put an effectual stop to the dissem;. nation of spiritualism in the after part of the ship; but meantime, our ship-keepers had laid their experience before the forecastle, the story of course gaining fresh horrors with every recital. The case was so plain-even the cook, who laughed at the whole matter, having to own that he heard the sounds, and that they were marvelously like human groans-that most of our greenhorns soon became devout believers in the immediate presence of a spirit in our midst, and the poor Portu guese, whose nature it was to be superstitious turned a sickly yellow, and began to shake in their boots.

Having heard the matter duly discussed, I ventured to suggest that it was clearly a humpback that made the mysterious noise. This was treated, however, with that degree of scorn which is 
nsually bestowed upon any reasonable explanation of a ghost story. My scornful laugh was severely frowned down, and I was informed by one of the wiseacres that the groans having evidently come trom my berth, and no where else, portended some anheard of accident to myself. So eagerly does ignorant humanity swallow the most egregious humbug, if there is only something supernatural about it, that of the sixteen men who had probably heard the same groans dozens of times in the boat, not one could now be convinced, by reason or ridicule, that those in question owed their existence to a natural cause.

I found myself regarded as a doomed man; and certain of the more friendly disposed privately advised me to prepare my mind for the approaching calamity, and even offered to share their berths with me, not considering it prudent that I should sleep in the haunted bed. If my excellent shipmates before cordially hated me for my unsocia. ble spirit, they were now doubly bitter against me on account of my present doubts; and one poor fellow went so far as to impugn my faith in the existence of a Deity, on the ground of my' scepticism on the subject of ghosts.

1 joined with the cook in laughing at their fool. ish fears, (which, by the way, procured me the present of a huge piece of pie from that worthy, who declared me to be a "good fellow"), and slept ss:undly as ever before in my haunted bed. place. 
The ghost was the staple of conversation ext morning at breakfast, and prophesies were freely made that before sundown that day, our boat would be stove, and I would be severely injured, if not killed. Fortunately for my credit, not an accident occurred during the remainder of our stay in the bay. Had I been in the slightest degree injured, or even had our boat been stove, as was prophesied, this would hare formed a well authenticated ghost story, and I should no doubt have been held up to future generations of whalemen as a melancholy example of stubborn unbelief.

Having now captured six whales, and the season not having proved nearly so propitious as had been hoped, there being comparatively few cows and calves in the bay, it was determined that we should divide the oil and proceed on our cruise. Our share of the proceeds amounted to one hundred and twenty-seven barrels. We finished stowing down and clearing up on a Saturday night, and as we had kept no Sunday for the past six weeks, the two captains determined that the following day should be a holiday.

And never was one more needed. Day after day we had toiled at the oars, amid rain and wind and cold, until we were completely exhausted in body and spirit. It was given out on Saturday night that there would be no cail of "all hands" on the following morning. Accordingly, I arose at nine o'clock, a much more comfortable hou 
than half past four, and after eating breakfast, began the day by a thorough wash and a shave, the latter more as a means of cultivating my dilatory and impatiently longed-for beard, than from any real benefit to be derived from the operation, in appearance or feelings.

Having donned a clean suit, a real luxury, and set fire to a cigar which $I$ found in a corner of $m y^{-}$ chest, I set out for the shore, in company with two Portuguese, determined on a tour of exploration. We had armed ourselves with boat-hooks and clubs, to kill the serpents which we should doubtless meet on the way, and now set out in high spirits. Unluckily, I was unable to wear boots, on account of sore feet, obtained by constant immersion in water, in the boats. So after penetrating a few rods into the jungle, I was compelled rather unwillingly to return to the beach.

My. companions, who proceeded, did not fall in with anything during half a day's ramble, but half a dozen serpents, and a lemon tree. They brought down their hats full of cooling, delicious lemons, which were soon turned into lemonade.

Meanwhile, the time hanging rather heavily upon my hands, I was tempted to a closer examination of a large ant's nest, which was pendant from the bough of a tree near the waterside. Climbing up this tree, I was shortly within reach of the nest, but had no sooner laid hands on it, with the design of plucking it off, (it was a mass as large as half a barrel), than its irrascible tenante 
issued out against me in innumerable swarms, and beforo I could drop myself down from my eleva. tion, I. was completely covered with the vicious creatures, all in a fever of rage, and stinging me to the best of their abilities.

To pull off my loose shirt was the work of a moment. In the next I was in the water, and my -assailants were swimming helplessly about me. This adventure, which procured me a few harmless stings, satisfied any lingering desire I might have entertained, to examine the interior economy of an ant's nest. After walking about the beach, killing a water snake, picking up a few harp shells, and basking for a while in the gental sun, I returned on board, utterly disgusted with Madagascar. With the exception of the lemons found by the Portuguese, we saw nothing eatable on the smaller island. None of the fruit trees generally so plentiful in the tropics, wore here to be seen, and I doubt if a day's journey through the dense jungle would have produced aught but snakes, of which there seemed a sufficiency to colonize all Ireland.

A little party was made up, while I was engagod with the ants, to explore a huge, nearly barren rock, lying at a distance of about five milss from onr mooring place, and between ourselves and the morth of the bay. This in our daily whaling excursions we had noted to be the resort of innumerable fly"ng foxes. I camé back too late to join the expedition, bit learned from them that they 
found the birds (?) flown. They saw nothing therefore, but traces, in broken branches of trees, etc., of their nightly resort thither. The captain, however, shot one of the foxes before the day was over. It was a black animal, with a head more like a bat than a fox, very sharp teeth, and long claws, and of about the size of a small fox. At a regular hour each day, betwieen ten c'clock and twelve, the whole flock which frequented the rock, took a flight over to the mainland, a distance of perhaps eight miles. They moved in a solid mass, like a flock of birds, and at a distance would certainly have been taken for birds.

The following day, (Monday), to the joy of every one, we got under weigh and stood out of the bay, bidding it adieu with a hearty determin. ation never to return. 


\section{CHAPTER XII.}

Ar. Mary, Ma.lagascar-Applying for Liberty-It is grantedSickness Asho:e-The Town and Fort-Two Men remain over night-They are taken sick and die-An Auction-Reflections-The Seychelies-Plans for leaving the Vessel-We raise a School of Whales-How a dead Whale makes headway against the Wind-Striking a Finback-"There blows"The excitement of "going on to" a Whale-Fast and Loose-A Whale's Revenge-The Boat Stove.

On getting clear of the land once more, the ship was headed to the southward, and the rumor soon got afloat that the captain intended running into St. Mary's, a French colony on the eastern coast of Madagascar, about two days sail from the mouth of Antongil Bay. The third day thereafter, having in the meantime seen no whales, both ships entered the harbor of St. Mary's. The town, or settlement, and fort lie upon an island separated by a narrow strait from the main island.

This is known among whalemen as the most fatal place upon the entire coast, for whites; but it is the only place on this part of the coast where fruits and vegetables are obtainable, and is, there. fore, frequently resorted to by whaleships.

On coming to anchor, all hands proceeded aft 
to ask the captain for a run ashore during our stay. Hereupon ho made us a little address, stating that he was quite willing to grant the required liberty, but telling us at the same time that while those who returned on board before sunset would run no risk of catching the fever, so surely.would those die who remained on shore over night, that he should refuse to receive them on board the following morning, considering them as certainly dead.

This sounded like humbug to some of the crew. But I had been warned against going ashore in this place, by the carpenter of the Betsy Ann, which ressel had lost here three of her men at one visit. I detailed the information I had received, to the rest, after we had retired to the forecastle, and convinced them, as I thought, that the captain's words were at least founded on fact.

I could hardly blame the disbelief of some, for the shores past which we had been sailing during the day, were so beautiful, and everything appeared to our rain-accustomed eyes so resplendent in the genial sunlight, whose like we had not felt for two months, that it was hard to believe grim death to lurk in every glade and hummock of the shore. Yet so it is. St. Mary's is unhealthy even to the natives, and I was informed that the European portion of the garrison, notwithstanding the greatest precaution and skill, is annvally decimated by the deaảly coast fever.

To seamen, used to take but inttle care, and 
scorning, in their robust health, all precautionary measures, one night's stay ashore is in nearly every case fatal, as was sadly proved by two of our crew, who were so fool-hardy as to overstay their time.

Taking all things into consideration, although I very strongly desired to leave the vessel, I concluded not to expose my life here. Life, thought $I$, is about all I have at this time to lose, and this I had rather part with to better advantage and on a more inviting occasion.

As our stay was to be short, we had but half a day's run ashore, one watch taking the forenoon, the other the afternoon. This gave us time only for an inspection of the barracks, a short ramble along the shell-strown beach, and a bargain with the natives for a quantity of cocoanuts and bananas.

The privates of the garrison are all natives, sepoys, while the officers and musicians are Europeans. The town is separated from the gar rison by a little arm of the sea; and at the waterside here, on the garrison side, are some huge storehouses, containing naval stores for the French squadron stationed in those waters. St. Mary's is risited by but few vessels. It was formerly a place of call for French Indiamen, but we were told that it was no longer so. A few whalemen, and an occasional French or English cruiser, with half a dozen bullock droghers, are the only ves. sels that enliven its harbors. 
The French have made more perssistent efforts than any other nation for the colonization and conquest of Madagascar, but their success has been marvelously inproportionate to their efforts. And their failure is not owing to the resistance of the inhabitants, although these have always hated and harrassed the foreigner; but almost entirely to the prevalence all along the seacoast of the island, of a deadly malaria, to which nearly every European resident sooner or later falls a prey. Grim death himself keeps guard at the portals of this fertile island.

Those who had "liberty" in the forenoon. returned on board in due time, laden with shells and fruit. Directly after dinner we of the larboard watch were set ashore, where we amused ourselves in various ways till half an hour before sunset, when all but two of our number rendered themselves on board. These two had determined to spend the night ashore, all our remonstrances to the contrary notwithstanding.

The following morning; as we were getting under way, they came alongside in a shore boat. As they approached the vessel, the captain hailed them, asking what they wanted. They were now ready to come on board, said they.

"I have marked 'deceased!' opposite you names on the muster roll. I consider yo'l dead men. I can not refuse to let you come $c r$ board but would rather you would stay ashore."

They protested that they were in excellent 
health, and felt not the slightest ill effects from their night's exposure.

"I will give you your clothing if you will stay on shore."

But they had no desire to be left behind, hav ing learned how little chance there was to get away from the place, and harboring no wish to starve on shore. So they were permitted to come aboard, and turned to their work as though nothing had happened.

"They'll die before three days are over," saia the captain to me, who had just then taken charge of the helm, the ship being now under weigh.

They were living and in apparently good health all day. But in the course of the following night both were taken sick, their first symptoms being a violent diarrhea, with cold sweats; and before forty-eight hours both were dead. Two others were meantime laid low with the same disease, and only recovered by the most faithful attendance, and the strictest care as to diet. This was our first burying of the dead, and as may be supposed from the suddenness of the affliction, it was a solemn occasion.

A few days after the burial, in accordance with universal custom on ship board, the effects of the deceased were disposed of at auction. In the merchant service, where the proceeds of such a sale go with the wages of the deceased to his heirs, perhaps a widow and family of children, an quction is often made the occasion of a display of 
generosity on the part of the surviving shipinates, who bid in the various articles at much more than their real value, and thus contribute their mite to the support of the bereaved family.

The men found in the forecastle of a whaleship are, however, generally castaways in the worldyoung fellows who have run away from the pater. nal home, and have no one depending upon them for support. The proceeds, if the deceased is out of debt at the time of his death, are of course reserved for the relatives; but these do not often know of the circumstances, and it is only by accident in many cases that they ever learn of the decease of the wanderer.

Of the death of these men, I speak reluctantly, and with pain. Both were delirious during the zreater part of their short illness, and-senseless for some time before death, so that the grim monster did not come with many terrors. But so those who looked on, vainly wishing for power to help, the spectacle was distressing. The sick men's minds were but little prepared for the great change; and although the captain endeavored to the best of his ability to administer to them in their sane moments the consolations of religion, it is much $\rightarrow$ be feared that they died "as the beasts that perish."

The gloom which nangs over a forecastle, when some of its members have been suddenly taken away, lasted here a shorter time, and was less 
generally felt than is usial. Our crew were not seanen. They had not the many finer traits of character which distinguish the true sailor. They were selfish, and their many months of close intercourse with each other had not called out hose strong feelings of affectionate regard which obtain among merchant seamen under such sircumstances.

We were now cruising off the beautiful shores of Bourbon again, but meeting with no whales there our captain determined to take a short cruise around the Seychelle Islands, and then pass on to the Sooloo sea. Several of our boatsteerers and officers had visited the Seychelles, and described them as most beautifully situated, fertile, and inhabited by a very innocent and quiet-lived peoplc, the descendants of French settlers and the natives. We therefore looked forward to having at last a pleasant run ashore, when we should arrive there, as it was understood that the vessel would make a stay of at least a week at one or $n^{t}$ her of the Islands.

Our passage, which was made much in the manner of a continuous cruise, the vessel being hov: to under reefed sails every evening, and standing on under short canvas all day, was thr pleasantest we had yet experienced. For fart of the way the south-east tradewinds wafted us softly - along through a climate which seemed that of an oternal spring, filling us with joyous anticipations 
of the delights of a land which lies in the track of these genial breezes.

For myself, I had determined that I would embrace the first opportunity to leave the vessel, as I was heartily tired of the monotony and dirt of a whaleship, as well as of the ignorance and brutality of those whom I was compelled to own as shipmates in the forecastle. These fellows, who claimed to be sailors because they had contracted all the vices usually, but in many cases erroneously, attributed to seamen, were to me day by day growing more unendurable. I had on several occasions cut off all communications with them, keeping company only with the three Portuguese. It is exceedingly unpleasant to hold such relations to individuals with whom one is thrown in constant contact, and I had already before we sailed into Antrngil Bay, made up my mind that I would at the first favorable chance leave the ship.

Of course this determination of mine was not hinted to any one else; although, as is usual in whaleships, the subject of "running away" was daily discussed in the forecastle. I had learned ere this voyage that " a still tongue makes a wiso head," and justly thought that the best way to securo the success of my scheme was to हay nothing about it.

I had some time since settled the preliminaries in my own mind, and now, as it became certain that we should visit the Seychelles, prepared some 
thin slothing, which I more especially desired to take with me. I judged, from what the boatsteerers sold me of the islands, that it would be almost impossible to get safely away from a whaleship there, unless some merchant vessel was just then in port, in which to take passage. I trusted that such would be the oase, but had determined to try an escape into the country, if nothing better offered.

By dint of diligent inquiry, I had learned all that was to be gathered from those who had before visited the place, as to the manners of the inhabitants, their language, the peculiarities of the different islands, and the modes of transport from one to the other. In fact, in the absence of all other excitement for the mind, my projected flight was the all-absorbing topic with me. I thought and dreamt of nought else, and often longed to take some one to my confidence, and talk over my ideas with him. But this I dare not risk.

- Meantime we were cruising along, keeping a sbarp lookout for whales, all hands being anxious to fall in with and capture a whale or two, in order that our contemplated stop at the Seychelle islands, which seemed somewhat dependent on this contingency, might be secured beyond doubt.

In fact, every circumstance in our lives was henceforth viewed merely as it would affect or be affected by the looked-for liberty at the Seychelles 
Was some one in trouble- "Never mind," muttered he to himself, "we'll be in the Seychelles soon."

Did one have a nice shirt, or a pair of trowsers less patched than usual-"Those are intended for my go-ashore suit at the Seychelles."

Was our diurnal duff raw, or rice badly cooked, "Wait till we get to the Seychelles," was the com. forting reflection.

Fiven a quarrel in the forecastle was temporarily patched up, to be settled by due course of fisticuffs " on our arrival at the Seychelles."

Our entire lives hinged upon that now delight. ful name.

It was when we were about half way between Bourbon and the Seychelles, that one morning whales were seen from the masthead. They were to windward of us, and were going along at steady rate, evidently making a passage. Hour after hour, as we stood after them, the musical cry of "there blows," was shouted from the masthead by the dozen men there gathered to watch the movements of the fish; until finally, at twelve o'clock, it was judged a favorable time to lower.

The whales had just turned flukes, and it way thought, as they were not under very great headway, that by means of oars and sails we inight place the boats in a farorable position for fastening by the time they rose again. Luckily for us, while yet urging the boats ahead, the whalee appeared at but very little distance from us, and 
the second mate at once pulled up and struck one We made for another fish, but the school immedi. ately disappeared, leaving the struck whale tc fight his own battles.

He however did not seem disposed to fignt. The iron had been darted into one of his eyes, and he was evidently in great agony. He did not sound when struck, as is usual with sperm whales, but after giving two or three violent strokes on the water with his flukes, began rolling round and round, until he had a large part of one tubfull of the second mate's line wound about his body. In his agony he would occasionally dart wildly through the water, but in a short time resumed his rolling again, seeming, I thought, to be trying by this means to extract the dart.

This rolling over of course gave a fair chance for a lance to be aimed at his breast, and in fifteen minutes after he was struck he was in his flurry, throwing his ponderous body about with the swiftness and agility of a mackerel.

When he was dead, and rolled over "fin out," we had an instance of how surely a dead whale will work to windward - that is, will drift agairst the force of both wind and sea. The ressel, by brisk working, had been brought to windward of our prize and hove to. While, however, the fluke chain and its adjuncts were being prepared, she drifted off again to leeward. It was to be expected that so unwieldly a body as a whale, lying helpless upon the water, would have drifted off 
nearly as fast as the vessel; but on the contrary, we could plainly see that it moved, if at all, the other way, against the wind.

"How do you account for that?" asked I of the mate, while we were trying out.

"Whalemen say it is caused by the lower fin of the whale, which hangs loosely down in the water as he lies upon his side. As the sea sweeps under the body, this fin catches the water in a peculiar manner, and being yet bound by the muscles, at each sweep throws the whale's body slightly back, thus neutralizing the force of the wave."

The next day we saw a huge finback of the kind called the sulphur-bottom. They are very large, and the blubber is reputed to make oil fully equal to sperm oil. Marvelous stories are told by whalemen, of the size of these sulphur-bottoms, some having been taken which turned out from one hundred and thirty to one hundred and sixty barrels of oil. They run, on being struck, just as does the real fin-back, and oftentimes sink when at the point of death, thus again disappointing the expectant whaleman.

The mode most depended on for capturing them is to go on with a lance and an iron in the bows. The larice being darted first, if there is reasonable cause to suppose that it has struck his life, it is immediately followed by the iron. If it has not inflicted a mortal wound, the iron is withheid, as in that case the fish would go off at top speed, 
and tne poat would only have to cut loose, with the loss of a harpoon and a portion of the line.

Many whalemen will not lower for sulphur-bot. toms, considering trem too troublesome. Ous captain was of this opinion, and the monster fien used, therefore, to pass the vessel with perfect impunity. Their spout resembles a sperm whale's, but they differ in shape, having no hump, and being much longer.

"Does any one ever try finbacks-or how is it known that they run?" I asked, one evening as we stood by the try-fires, discussing the merits of sulphur-bottoms, and other running whales.

"Yes," said the second mate, "most people have a desire to satisfy themselves upon the question, and generally do so before they can rest easy while a fat finback is sailing lazily past them. Last voyage we were cruising in the Sooloo sea, where the skipper now talks of going, when onc beautiful afternoon, as we were gently gliding over a sea almost as smooth as glass, a good sized finback hove his ridge out of water just ahead of the boat. We had lowered for a school of sperm whales, gallied them by some accident, and were now returning aboard empty-handod, to get a jawing from the skipper. As I sat in the bow, whither I had gone to get under shelter of the sail, which flapped lazily against the mast, the thought str uck me to fasten to this fish, and prove for my. what the consequences of such an act would be 
"I motioned to the boatsteerer to lay the boat round, so that with the little headway she had she would glide on him and give me a fair dart. As he came within reach I put out my utmost strength and sent an iron decp into his bilge.

"He never stopped to kick, but putting nis head on a level with the water's edge, started off at such speed as I don't believe whale-boat ever went before.

"Mast and sail were carried straight over the stern, and as the boatsteerer, in obedience to $\mathrm{my}$ cry, held in the line, before I could grasp the boat-hatchet and cut line, we were half full of water. With such force was the boat dragged through the water that she leaked like a sieve from the strain. This specimen of a finback's runuing powers satisfied me fully."

It was on a calm and beautiful day, a week before we saw the long wished-for Seychelles, that the captain, who was taking a walk around the vessel, noticed the man at the foreroyal-masthead gazing placidly down upon deck, instead of keep ing his eyes on the waste of waters before him.

"There are no whales down here, Henry," re marked he, by way of reminder of his duty.

"Well, captain," drawled out Henry, who was as good-natured and stupid a fellow as ever lired " there are none up here."

The captain grinned, as did all who heard the reply. Scarce a minute had elapsed, however, 
before the mate, who was at the main royas masthead, sang out lustily, "There she whitewa. ters," a cry which roused all hands from a pleasant doze, and caused some of us to run up the rigging to examine for ourselves the "whito. Nater."

"There blows," repeated the masthead's-man

"One," said the captain.

"There blows!" from the masthead.

s: Two," from the captain.

"There blows!"

"Three."

"There blows!"

" Four."

"There blows!"

"Sperm whales, by all that's good and bad,' now shouted the captain in ecstacy. "Get yous boats ready, while I go aloft and watch them."

There was no necessity for backing the mail. Fard, for there was scarce a breati of air, and the ship had not steerage way on. The whales were about two miles otf, and it was determined to lower as soon as they turned flukes, and try to get fast the next rising.

"You may as well cast loose the paddles, Char. ley," said the boatsteerer, as I was making ready some of the boat-gear, "we shall not use the oars much to-day."

"There goes flukes," was the signal for lowerIng the boats, and we set out merrily for the spot 
where the fish were expected to make their next appearance.

After pulling about a mile, the oars were peaked, and the balance of the distance was overcome by means of the paddles. To use these, the crew sit upon the gunwale of the boat, with their faces toward the bow. This is therefore a much pleasanter way of approaching a whale than by pulling, or rowing, as landsmen would say. In fact, although much is said of the excitement of whaling, I doubt if much of this excitement is felt by those who, sitting with their backs to the fish, have no further share in his capture than placing the boat in a position to enable the harpooneersman to "make fast."

The boatheader, as commanding officer on the occasion, no doubt feels a pleasant degree of elevation, while the boatsteerer, if he has confi. dence in the "header" and in himself, is also under the influence of a pleasing excitement, and thinks it glorious sport. But to the men at the oars it is, I judge, a good deal as though they were being conveyed to the center of a field of battle, klindfolded, and seated on a car, with their backs to the enemy. It is only in fine weather, when sailing is feasible, or paddling becomes necessary, that I ever saw a whaleboat's crew entering into the spirit of the chase and capture. Then indeed, as on this occasion, it is glorious sport.

The whales rose one by one, and at considerable distances from each other, thus giving several 
boats an opportunity for getting fast Our chance was, however, likely to be the best, as tie whale nearest us was approaching the boat, meet. ing her head and head.

"Paddle silently, boys," whispered the mate.

We dipped our paddles into the water witk. long and easy sweeps, scarce breathing, for feal of startling the whale who, occasionally spouting, was surging slowly toward us. He was entirely unsuspicious of our presence, and acted as though half asleep. More than fifteen minutes elapsed before we were sufficiently near to lay aside our paddles-fifteen minutes of eager excitement to every one of us.

The boat soon lost her headway, and now lay almost motionless upon the water. The boatsteerer, iron in hand, stood with his knee against the lubber-chock. We had resumed our seats, but with one hand resting upon the oars, were engrossed in watching the whales. The mate, in the stern, having thrown the bight of the line about the loggerhead, was now slowly laying the haat around with his steering oar, to give Barnard a petter chance.

On came the whale-very slowly, I thought.-every moment of delay increasing the excite. ment. Every breath was held; no one dared move a jot.

The dropping of a pin in the boat might almost have been heard, and if heard would certainly have excited numberless internal oaths, so fearful 
were we of disturbing the yet unconscivus whale. Now we were within dart.

Why don't you throw your iron? is a question frowningly expressed upon every countenance.

Giving the boat a last strong sweep around, so as to bring her bows at right angles witk his body, the mate nods, us a sign to dart, and on the instant a startled splash of the whale's flukes proclaims that we are fast.

Drawing a long breath, we grasped our oars and backed water. The whale darted under the boat, but did not sound to a great depth. All was now noise and activity.

"Haul in, he's not going to sound," cried the mate.

"Are those lances ready?"

The lances were already out of their becket, and in another moment were on their rests. The whale, after lying for a few moments quite still at the depth to which he had sounded, as we could tell by our line, rose to the surface not far from the stern of the boat, and "throwing his jaw off," (as opening his mouth is called), darted about in a circle, evidently preparing himself for mischief. As he swept in a circle around the boat, we were compelled to follow him, turning the boat continually to keep her head on. The mate kept a taut line on him, determined to lose no time before lancing. But his gyrations did not afford an orportunity. Twice he darted for the boat, but each time sour.ded to a little derth before 
coming within dart. This play continued half an hour or more, and our utmost efforts were required at times to keep the boat from being capsized, so - wiftly did he drag her around.

"If we only had a loose boat here now, to lance uim, or engage his attention for a moment," muttered Barnard, whose berth at the steering oa was just now of the most unpleasant.

"Blast the ugly beast, Barnard, we'll have to give a little more line; the boat came near being capsized that last round," said the mate.

For a moment, indeed, this had been deemed mevitable, but by instinctively crowding over to the upper side, and by the activity of the boat steerer with his steering oar, we were saved from that mishap.

"There, we're loose by all that's devilish!" was Barnard's exclamation as the boat suddenlv ceased to whirl round, and our line floated loosely on the water. The whale, as though knowing he was released, immediately started off at a speed which rendered all chase useless. He had gotten the line into his mouth which was wide open all the tirne, and with the constant strain it had chafed in two against the rough skin on his jaw.

With disappointed looks we watched our whale. He made good headway from us, and at last turned Aukes at the distance of a mile, still heading from as.

"I did not know but he would come back, and give us another chance," remarked the mate. 
"He seemed to be an ugly tempered fellow, and they sometimes come back to have a little re. venge."

We laughed at this, and commenced pul'ing down toward the other boats, which we saw about two miles off in a direction opposite to that which our whale had taken.

St)me fifteen minutes had elapsed, and we were yet slowly pulling along, discussing our adventure, when the boatsteerer suddenly shouted at the top of his voice,-

"Pull hard! pull hard! there's a whale under us!"

Before this could be done-in fact, before he had fairly uttered his warning-we heard a crash, and felt the boat lifted up under us. In the next moment all but the mate and myself were thrown into the water, and the boat was restored to her equilibrium, half filled and leaking fast at every seam.

The whale, which had struck beneath the tub. oarsman's thwart, was now standing perpendicularly in the water, with his jaw thrown wide open, and his junk raised in the air. Thus he remained for the space of a minute, seemingly waiting for something to drop into his extended maw: then resuming his horizontal position he once more made off.

Had the men been in the boat, the mate would have fastened to him again, wrecked as we werc. But there, was no one to lay the boat's head round: and to have struck him from the stern would have 
exposed all to almost certain destruction, without any reasunable prospect of getting the whale. We immediately commenced bailing the boat, each man as he crawled aboard over bow or stern (for so full of water was the boat, that a touch upon her side would have capsized her), going to work. Bu skets, hats, shoes, and every thing else available were brought into requisition, and we soon got the water so far under that two men could be set to work with paddles; and thus while the rest bailed we slowly reached the ship. Here the boat was wrapped round with mats and ropes, and hoisted in to be repaired. A few of her after timbers were broken; nearly every plank was started, and her keel was splintered in two places.

The whale, as we knew by our iron which was sticking in his back, was the same we had struck. After going down at the distance of a mile, his temper probably got the better of him, and he returned to wreak revenge on his assailants. Barnard, who was the first to discover him, said he saw a huge body glistening as it rose rapidly under the boat, and at once guessed it to be a whale, not thinking however, till we all saw the iron in his back, that it was the whale.

None of the other boats succeeded in getting fast. The crews said that although that portion of the school which they were pursuing, was at least two miles from us, they knew the moment we got fast, by the sudden disappearance of every whale. 


\section{CHAP TER XIII.}

MAHE-A Newspaper-The Islands-Their Inhabitants-A lazy man's Paradise-Plans for Escape-George Thompson's Yarn -A Cruise in a Whale-boat-The Escape-Sailing along Shore-The Arrival at Mozambique-Concerning Attempts to Desert from Whaleships-Some Reasons for the Frequency of such Attempts.

WE cruised for about a week after the accident described in the preceding chapter, in hopes to see the school of whales again, and make prizes of some of them. Not meeting with whales however, at the end of that time, we stood in for the land, which was never during the week more than one day's sail off, and in twenty hours were anchored in the harbor of Port Victoria, or Mahé, as it is more generally called, that being the name of the Island upon which the town is located.

We came to anchor at night, and at early dawn were boarded by the harbor master, (whose principal business seemed to be to receive and dispense news) and shortly after by a host of natives, who brought alongside all manner of fruits and regetables, and-wonder of wonders-some copies of a newspaper, published on the Island.

"The Seychelle News Letto"," so it was called, was 
a diminutive specimen of newspaperdom, prirted on very coarse, dark paper, and from what is known by printers as pica type. One-half was in English and the other half French, a great part of the latter being taken up with the neverfailing feuilleton. I purchased a copy for a plug of tobacco, and read the news while discussing my breakfast, a compound luxury I had not enjoyed for a long time.

Mahé, which is the principal, and I believe largest of the Seychelle group, is sixteen miles long, and about four miles broad. It is mountain. ous, as are all the islands in the Indian ocean, but is withal very fertile, and has a most enchanting climate. The natives, who use the French language, understanding but little English, are of various hues, from the light olive of the southern Frenchman to the coal black of the native Madagassy.

These islands were first settled by Frenchmen, and belonged to the French until 1794. They are now a dependency of the government of the Mau . sitius. But although the English flag flies there, and British colonial laws are administered, tho inhabitants yet cherish their love for "la belle France," and I never heard "vive la republique" shouted with more fervency than by one of our visitors when talking with the captain on the then recent great events in France.

In days past, before the English abolished slavery, numbers of Madagassy were brought to 
these islands as slaves. Their descendants still form in great part the laboring classes. They are a bocrish and rude set, and have profited little from iheir admixture with the gentle and peacefol $\mathrm{F}_{\text {i }}$ ench creole population, except indeed where, as is to a considerable extent the case, a fusion of the two races has taken place. The whites are still the leading people, and have the commerce of the islands in their hands. They take great pride in the purity of their blood, and look down with no little contempt upon mulattoes and quad. roons, while these in turn despise the woollyheaded descendants of the Madagassy. The whites and those of mixed blood have all the grace and liveliness peculiar to the French character, tempered with a gentleness which renders the men almost feminine in their manners, and makes the women very charming.

The islands-there are thirty in the groupseemed to me the realization of a lazy man's idea of paradise. The constant sea-breeze tempers the heat of the sun, and makes the air slightly invigorating instead of enervating. All kinds of tropical fruits grow spontaneously, or with the least possible degree of care, in a most generous soil. Shelter is \& arcely needed, and clothing, beyond what decency prescribes, is altogether superfluous. It is not to be wondered at, therefore, if the people are "doless," and live contentedly a quiet, inactive existence. On many of the smaller islands, so I was informed, bananas, bread-fruit and 
fish are the principal food of the natives, who build their huts under the shade of a pleasant grove, and, to use an expression of our black sook, "have Sunday every day in the week."

No sooner were we in port than plans without number were formed and discussed in the forecas. tle, by those who had grown dissatisfied with the ship or the business she was engaged in, aud therefore desired to leave-or to state it in bluni English, to desert. Of our entire crew, leaving out of consideration the boatsteerers and officers whose interests were of course identified with the vessel, none but one Portuguese and the black cook really cared to stay. Each of the others had a plan for making good his own escape; and at a distance, while we were yet at sea, each of these plans looked feasible enough.

Some thought to take one of the ship's boats, and go in her to some of the other islands, where, setting the boat adrift, they would conceal themselves till the ship was necessitated to leave those waters. Some thought to procure a passage to a neighboring island in a small coasting pinnace. Others yet were convinced that they would be abie to subsist in the mountain region of Mahé, and render all search for them futile.

Once in port, and with the land staring them in the face, several lost heart altogether, and abandoned further thought of an undertaking in which they would have, without means, to cast themselves among strangers, most of whom could not 
even understand their language. The rest found their plans of escape so little conformable to the existing state of things, that they were forced to devise new wayk and means.

Meantime, the captain was making preparations to thwart any attempts at desertion, by putting such of the natives as would serve him, on the alert, preparing to use them as scouts who could be quickly put upon the track of those who failed to return on board in due season. Whaling captains, in general, are up to pretty much all the tricks of their crews, and always chose a "liberty" port with an eye to the facilities it affords for retaking fugitives. Not one whaleship in fifty brings home from a three years' cruise the crew which took her out. Few young men are satisfied with the monotonous life of a whaleman, and fewer yet are proof against the seductions of the shore, when visiting it, as we were now, after eleven months of hard fare and all manner of privation. So that most of those who complete the vnyage, (here of course I speak of the forecastlo Lands), do so not from choice, but because the vigilance of the captain, or their own ignorance and porerty of resources, has rendered theix escape impossible. Nothing is more common in a whaleship's forecastle than to hear the crew, even st ar advanced stage of the voyage, speak of their. hopes to escape at the next port.

And here is showr the wisdom of captains and owners in shipping 1 one but green hands. Sailor 
it is next to impossible to keep on board when they once take it into their heads to leave. Used to foreign lands and ways, they fear hot to throw themselves at haphazard among any people, sure that they will be able to work their way through "somehow." Besides, to the sailor all other ships are open, whereas the ignorant whaleman, making his first trip, is worthless as a seaman, and utterly unknowing of anything beyond his own ship.

Notwithstanding all these disadvantages, however, nine out of ten in every whale crew desert, generally paying for their foolhardiness by a most wretched life of exposure, privation and poverty, and in the end falling upon the tender mereies of some American Consul, or working their way homeward, broken down in health, and spirits, and morals.

Numberless stories are told of escapes of whalemen from their vessels. I knew an old salt, who was one of the crew of a vessel cruising for whales on the coasts of Madagascar. The crew were dissatisfied and determined to leave, but the captain, sware of their purpose, took care to enter only usse ports, principally on the island around which chey were cruising, where he knew that his men either dared not go ashore, because the natives would kill them, or where for ten dollars he could have a whole crew caught and delivered to him.

"We were lying in Nos Beh, (an island off the the northwest coast of Madagascar)," said George Thompson, who spun us this yarn, one midwatch, 
while snugly stowed away under the bulwarks of an old lime-juicer. "There is a French settlement there, and the captain had told us, on com.$n$ to anchor, that this was our appointed liberty i lave, informing us at the same time with a tri:mphant grin, that he was well acquainted with the commandant, and that if any of us felt inclired for an excursion into the country, we might mak a sure of a safe escort back within forty-eight hour after our departure from the ship.

"Six of us, including one of the boatsteerers, had made up our minds to run away at all hazards; but we now found our purpose completely frustrated, at least so far as taking refuge on shore was concerned. Upon consultation, we resolved upon the rather desperate measure of going off in one of the ship's boats. But where to? Johanna and Zanzibar were suggested, as being the nearest ports; but the first was a regular resort for whalemen, where we would no doubt be detained, and the last was too far off, while in addition there was an American Consul there, into whose clutches it would not do to fall. We finally concluded that Mozambique was the only safe place for us, and although this would be a long passage to make in an open boat, we determined to try it.

"Three days and nights were consumed in preparation. A considerable stock of bread and molasses was provided, with a very little salt $r$ rk, this being too great an incentive to thirst to be of muck use to us. The water breakers in the 
ther boats were carefully filled, in readiness be placed in the one destined to carry us.

"On the third night, about two o'clock, we fastened the cabin doors as well as we could without noise, and then, all things being in readiness, clothing and provisions fairly stowed away, and oars ready for instant use, we rapidly lowered away the boat, and jumping in, put off from the ship.

"The noise we made in lowering away roused the officers, and by the time we were half a dozen ships' lengths from the vessel, we were hailed by the captain, who called on us to return, threatening all sorts of vengeance if we refused.

"'Pull away, lads,' said one of our number, 'we have no breath to waste.'

"We were momentarily increasing our distance, and would soon be safe from all pursuit, should such be made in the boats; but now came a shot, which struck the man at the steering-oar. On seeing the blood, one or two of our number grew scared, and proposed to return.

"'Pull ahead,' said the wounded man, sternly; as he tied his neckhandkerchief about his wounded thigh.

"A few strokes more and we were out of reach of tho shot which were still sent after us; and soon a projection of the land hid the ship from our view. We now set up the compass with which every whaleboat is furnished, and hoisting our sail, put the boat on her course for the mainland 
of Madagascar, which would be visible at daylight. But to make our escape doubly secure, we continued pulling for some hours longer, not knowing but that our eaptain would pursue us with the ship.

"Daylight disclosed to us the land of Madagassur ahead, and as no pursuers appeared, we ship. ped in our oars, and stood along under sail. pleasantly enough. The morning was bright and calm, with a good breeze, and as we skimmind along over the water, and began to realize that after two years of subjection we were once more our own masters, we felt light-hearted and equal to any emergency. The wound of our steersman proved to be slight, a mere scratch, which would not trouble him.

"It now became necessary to take a cool survey of our position and resources. It had been deterinined beforehand, that we should sail along the western shore of Madagascar until we judged ourselves abreast of Mozambique, and then bold'y stand across the channel, which is just there at the narrowest, being not more than two hundred miles wide. By actual count of our-biscuits, we found that we had sufficient to last us, on a moderate allowance, for three weeks. Of water we had onough for ten days, we judged, but of this, as wo were to sail along shore, we hoped to procure a supply before we were entirely destitute.

"Two of our number could navigate, and wo had with us a quadrant, a Bowditch, and a small 
chart of the coast of Madagascar, by the help if which we trusted to be able to find our way over the deep. We elected Long Tom Coffin, the man who was shot, our chief, and then divided our. selves off into watches, holding the helmsman for the time being responsible for a correct reckoning of the course and distance made during his trick, and putting upon Long Tom the labor of keeping a regular log.

"A spare royal which one of us had thrown in, made a most excellent shelter for the watch at night, and for all hands that desired to sleep during the day. You can have no idea how well we got along. The weather remained very fine, and the wind was continually fair, while, sailing along ahore as we were, at no greater distance than was necessary to skip, as it were, from headland to headland, the sea was always so smooth that our little craft got over it at a remarkable rate. We named her the Dancing Feather, Long Tom swearing that she danced better than the prettiest girl he had ever seen.

"After all preliminaries were settled, and we were taking a quiet look around, Tom, who seemed to have thought of everything, produced a bun. dle of books. He had ransack id every chest in tite forecastle, and borrowed ail he could of the koatsteerers. The two dozen volumes of tales and novels which he now pitched out to us as the cesult of his efforts, were most welcome accesscons to our amall stock of amusements, and we 
whiled away many pleasant hours in their perasal, and in talking over the characters found in them.

"On the second day after our departure, a council was held to determine what course should bo pursued, should we fall in with vessels. After due consideration, it was decided that should we see a ship under sail, it would be prudent to keep out of reach, unless she were clearly a merchant vessel, when, if it was desirable, we might ask them to take us on board. Of the native boats and Arab coasters, we votad ourselves not afraid. We could at any time escape from such by means of our oars, and thought our six selves, armed with the irons and lances which the boat contained, a full match for any reasonable number of Arabs.

"Our dead reckoning and observations proved that in the first thr e days out we made one hundred miles per day, which, although not a very fine run for a large vessel, was exceedingly good progress for a whaleboat. At this rate, we should not be more than eight or ten days under way. But the fourth day came a calm, and in the afternoon a heavy rain squall, which was very useful to us, as by means of our royal we caught sufficient water to fill up every vessel we had in the hoat. Our biscuit we had stowed away safely in the stern sheets, and under the bow, where the rain could not injure them.

"We were now prepared to make the entire trip without touching at any intermediate point, 
circumstance of which we were very glad, inasuuch as it would have occupied valuable time to search about for water, as well as exposed us to an attack from the natives. As we became more and moro at home in the boat, we grew bolder, and stood out from shore further. The weather remained delightful, and we now sailed just in view of the highest points of the land we were passing.

"On the fifth day, we knew by the sharp easterly curve the land took, that we wero approaching the point where we would stand across. By the quadrant, we could ascertain the correct latitude each day at noon, and thus make sure that we did not overshoot the mark.

" 'As for longitude,' said Long Tom, 'we can't miss it : once get in the right latitude and sail due east, and you will run against the town, if it is not sunk.'

"On the eighth day, our navigators announced that we were now at that point of our journey where we must stand east. We had been sailing east southeast some days, and the change in course was not therefore so great.

" 'Look your last on Madagascar, boys; I don't believe any of you want to soe the wretched hole again,' was the word of our chief, as he laid the boat off shore.

"We watched the receding hills without regret, for they were sonnected in our minds with two long years of toil and drudgery, for which we were never to receive any recompense, 
"Our passage was a pleasant one, and we were so fortunate as to miss the port by only about twenty miles, which we soon retrieved when liong Tom had gotten a correct observation, and determined on which side, north or south of the plare we had gotten. As we neared our haven, the question was, how should we present ourselves, what yarn were we to spin to the Portuguese. and how account for our possession of the boat.

"' For,' remarked Long Tom, who had gotten to be our oracle by this time, 'people don't commonly navigate the ocean in whaleboats, and I dare say, we'll be looked upon as rather remark. able specimens of humanity, in this out of the way corner of the world.'

"'They are Portuguese,' said one, 'and won't ask many questions.'

" "No, but they may put us in their dirty calaboose, and poison us with garlic, in order to get possession of the boat.'

"Long Tom, who was always listened to with attention, now proposed to sail boldly in, and if asked our business, and where we were from, state that we were lost from a whaleship cruising on the coast. We should undoubtedly gain time thus to look about us, and for the balance of our talk, let it be as little as possible.

" And as I am the only one of you that under. gtands Portuguese, I don't believe you will com mit yourselves.'

"We made the harbor about ten o'clock, on the 
fifteenth morning after our departure from the ship. As we sailed in toward what seemed to be a landing on one of the islands in the Bay, we passed a long, rakish looking brig, the officers of which hailed us, and after hearing our story from Long Tom, asked us to come alongside. She was a trader, bound to Goa, and had lost her hands on the coast. After some hesitation, we agreed with the captain to go in her as far as Goa, there to be regularly discharged. The whaleboat we sold to a rich old Portuguese, dividing the spoils, which amounted to nearly one hundred dollars.

" "That's all you'll ever get for your two years hard work, boys, so make the most of it,' said Long Tom, as we shared it equally among us. We ail went to Goa, and thence Long Tom and I sailed for Pondicherry. But that's altogether another yarn, which I can't spin to-night."

If the reader will pardon this long digression, we will now return to the subject which caused it-deserting from whaleships. The most desperate expedients are sometimes adopted to get clear of an unlucky or unpleasant vessel. Thus it is on record that the greater part of a whaleship's crew once drifted on shore on the cover of the tryworks, which they had launched overboard for that purpose. This cover is large, square and flat, with sides about one foot deep.

While we were cruising in the Pacific, in tho United Siates service, a more desperate case than even this occurred at Honolulu. A man who had 
rainly tried to desert from his vessel, having been several times retaken when making the attempt, deliberately laid his left wrist on a chopping block and cut off the hand, exclaiming as he did so, "Now you'll have to let me goo."

There is but little done by the officers to make the life of the crew of a whaleship pleasant. On - the cruising ground there is nothing to do. This adds another misery to the already sufficiently wretehed existence of the whalemen, and thus makes it entirely unbearable. To be cruising about, far at sea, is monotonous enough, even if, as in the merehant vessel, the daily routine of labor is so arranged as to keep both hands and minds of the seamen employed. But when, as in the whaleship, no attempt is made to relieve the tedium of the voyage, no expedient devised for making the time pass more lightly and pleasantly, a single sruise of six or eight months generally infuses into the new hands a strong desire to make their escape from the vessel. Thus it was with our arew. 


\section{CHAPTER XIV.}

* Liberty" - The Massowah Vessel-She wants a Hand-1 go alongside-The Vessel is searched-We sail-The trip to the Mauritius-The Crew-The Captain-Discipline-The Land -Port Louis Harbor-I gain an unexpected Friend-I take charge of the Captain's Roat-A trip to Tombo Bay-Paul and Virginia-The Island-Its state under the FrenchUnder British rule-Malabar Apprentices-Malabar TownThe Natives-Chinese.

To return to our own ship. On the fourth day after our arrival in port we were allowed a run ashore. No one of the crew but myself was the possessor of a cent of money. But all had what is called "trade," such as calico, tobacco, beads, etc., which they could here readily barter for such purchases as they desired to make.

When we first anchored in the harbor, I noticed a large vessel with French colors flying, also at anchor. On inquiry, one of the natives informed ne she was from Massowah, and had on board a sargo of horses. She hailed from Bourbon, but I was told was now bound to the Isle of Franco. She was to sail in a very few days, and I determined to make an effert to sail in her, as this seemed to me the surest chance for effecting $m y$ 
escape from bondage. During my ramble about the shore, and while considering as to the best method of getting on board to ask the captain for a passage, I was so fortunate as to meet him. A native of whom I had asked some particulars cor. cerning the vessel, pointed him out to me. I a once addressed him, stating my wishes, and alsc the fact that I was a merchant sailor, and would endeavor to make myself of use to him.

$\mathrm{He}$ answered me in tolerable. English, that he wanted a hand, but that he feared I would not care to come with him, when I once knew the manner in which his crew lived.

"We are used to our country fashıon of having only two meals per day; and bread is something entirely unknown to us."

I answered, that I thought myself able to subsist on that which supported life in others, and would be very glad of a chance to try it at any rate.

"Well," said he, "we shall sail to-night, and if " you can get aboard during the night I will take you with me, although I fear I shall get myself in trouble with your captain by it."

Much rejoiced at my unexpected success, I returned on board about noon to get my dinner, and took that occasion to put on two suits of clothing, and place my peajacket and some other little arti. cles in a bundle, and with this, as trade, had my self set ashors again, determining to stiby, and go 
off to the "Hercule" - that was the French barquo' name-in a native boat during the night.

In the course of the affernoon I engaged a native, who for three dollars, more than half my fortune, which consisted at that time of five Mex. can pesos, engaged to convey me on board at any time during the night. Thinking that after selling himself to me, he might, in hopes of a better price, betray me to the captain, I inserted a clause in our agreement, by which he was to remain with me until the time arrived to go on board, and to provide me until then with a shelter. We accordingly walked to the outskirts of the little town, where my man had a rude hut under shade of some banana bushes. Here we lay down to await the time when the elick of the windlass should tell me that the barque was getting under way.

The weary hours passed slowly by. I thought the sun was never going to set, and when it became dark, the suspense was yet more disagreeably prolonged by the close watch necessary to be kept upon the ship, lest she should be under way before we were aware of it. At last, about twelve o'clock, we heard the windlass, and in a moment after saw the foretopsail drop. Running hastily down to the shore, we jumped into a canoe and paddled off at full speed.

"There's a pirogue from your shị, master," said my boatman, when we were about midway hetween the shore and the barque. 
Sure enough, we coull just discern thro agn the darkness one of our boats, apparently about to board the barque. I thought for a moment that. my hopes were nipped in the bud; but after lying still for a few minutes, I told the fellow to pad die on.

We will go alongside on the other side, thought I, wnd remain there until our boat leaves, when I can get on board in safety.

When we got alongside, I could hear the voice of our mate talking to the captain, who denied stoutly that I was on board.

"You can take lanterns and search the hold, sir," said he to the mate, as that worthy still seemed unconvinced.

Lanterns were accordingly produced, and while I lay concealed in the canoe under the quarter, the mate, accompanied by some of the crew, walked through the half empty hold, (she was partly in ballast), closely examining every nook and cranny, sounding the water casks, turning over spare rigging, and looking among the horses. The search was vain, and with sundry curses, and threats as to what would befall me were I caught, the mate at length descended into his boat, and with joy I heard them pulling off toward the ship. Orders were now given, in French, to man the windlass and heave up the anchor. I waited till the ship was fairly under way, before I climbed $\therefore$ the ueck. There the captain received ma. 
assuring me that had I come on board sooner, I would certainly have been caught.

With a light heart I bounder to the masthead to loose the topgallant and royal, and in a very short time we were out of the harbor-and I was once more a free man. For the state of subjection in which men are kept on a whaleship, when contisued for such a length of time, becomes nothi ig less than the most abject slavery.

After the anchors were secured and all made ready for sea, I wrapped myself up in my peajacket, and stowing myself snugly away under the weather-bulwark slept till daylight. On waking up, I took the wheel, and steered from that time till eight o'clock. During this time the captain explained to me the internal economy of the vessel, which was certainly new to me. The crew, numbering fifteen, were of all shades of black, from charcoal to dark brown. They were natives of the Mauritius or the Seychelles, and were not sailors, but simply rope-haulers and horsetenders. They received ten dollars per month, and for this kept watch at night, made and took in sa:- , steered the vessel, and tended the wants of the cargo of horses which was now on board. If the rigging required repairs, the mates were obliged to do this themselves, and as for sail-mend. ing, about that even they knew but little.

The crew slept upon deck, each man having a mat and a jacket, the mild air rendering other 
covering unnecessary. They were allowed two meals per day, the first at nine o'clock, consisting of a modicum of boiled rice with a little wretched cocoa; the second at three o'clock, consisting of another portion of rice, and a small piece of salt beef. Neither bread $n u r$ any other preparation of flour was known on board, not even in the cabin.

No one who has not experienced it, can know how exceedingly difficult it is for one used to a civilized diet, to make a satisfactory meal without bread. It was a hard school for me, here. But hunger makes a sauce for every food, and it was not long before I could relish my dinner or breakfast of boiled rice as well as any one of those who were bred to it. Of course on such slight diet men do not work very energetically. Our crew were as lazy a set as ever lived, and their diurnal task of feeding and watering the horses was spun out to last nearly the entire day.

For two days I took share in this labor. By this time, however, the captain, who had seen sume sail-maker's tools in my little bundle, and had ascertained that I could work with the needle, found some sail-mending for me to do, and henceforth my work was under the quarter deck awning, patching up old royals and top-gallant-sailis, flying jibs and studding sails. I soon learned sufficient of the mongrel French spoken un board to make my wishes known, and understand or ders, and wher my rebellic is stomach was onco 
resonciled to the strange diet, I had a not uncon. fortable place on board. The only thing against me was my color. To my.misforture I was the whitest man on board, and with the exception of the captain and chief mate, the only one who was purely white. This caused me to be looked down upon by my black friends, who, when I would commit any little extravagance, such as making myself a wooden spoon wherewith to eat my rice, (they used their fingers, in the Adamic style), or washing my hands and face at the close of a day's work, shrugged their shoulders in pitying contempt, and declared that nothing better was to be expected from a man of my color. Nevertheless, as they found me ready to take my share of whatever work was going on, and always disposed to converse to the best of my ability, they voted me in the main a good fellow, much better than the common run of white folks. And as I entertainod my own opinion as to their merits, I could afford to be amused at their ideas of me.

My ignorance of their barbarous jargon seemed to them, however, the oddest of my peculiarities, and they could never laugh enough at my m:stakes. I had long ago learned the propriety in such cases, of laughing with the crowd, and prac. ticed largely upon this theory now; not, however; without an occasional internal malediction on the stupidity of these fellows, who could so easily ignore all knowledge not possessed by themselves With the captawn I was shortly a favorite, 
inasmuch as I was of service to him in varicus particulars where his natives were useless. He spoke to me often of his voyages, and of the ifo-a very lazy one it was, too-which he led, snd in which he delighted. He was a man of some means, had a plantation in the Mauritius, where he managed to have a little sugar raised; owned the vessel of which he was now master, and made in her generally a voyage each year to Massowah, or some other of the ports on the Red Sea, for horses, and a trip or two to Madagascar for cattle, making long stays on shore between these trips, and evidently enjoying his family life very highly. He was forty-five years of age, tall, portly, gray haired and good natured, and prided himself much on his purely French extraction, and his name, Lepelletier, which he maintained occupied a conspicuous place in the annals of la belle France. As in duty bound, he despised Johnny Bull, and thought that the greatest calamity which ever befell his native isle, was its coming into the possession of the British. Everything, he complained, was now taxed. The slave trade and slavery was abolished, but the wretched Hindoos who were yearly brought thither under the name of free laborers, were in a far more abject condition of slavery than ever were the Madagassy who were formerly held in an easy bondage under the French.

"In former times there was some blood and some geod society to be found in Port Louis; but 
now the shop keepers, a wretched set, had the oway, and the Acadian simplicity of the French regimé was gone."

He spoke tolerable English himself, but would not be complimented upon it, and strongly advised me to learn French, as the only language fit to be spoken by honest men.

I delighted much in his talk; and his descriptions of the indolent easy life which was formerly the fashion among the French planters and residents, were charming to me, who have myself a keen appreciation for "a bit of the dolce." On board his ship, where he was Lord Paramount, all lived in this indolent, half dreamy state. To brace the yards or pull home a sheet was a labor requiring much deliberation. Half an hour generally elapsed between any order and its fulfillment; and no work not absolutely necessary was ever attempted. Studding sails were held as abominations, fit only for a restless hurrying Jean Bull, and even royals were not looked upon with favor.

I, who had been trained in the hardworking merchant service, would have labored from eight till six, on my sails; but this was not suffered. S'x hours per day was quite sufficient to wor $k$, and even this time was in great part wasted in ioung. ing and conversation: so that ere long I had got tó be as inveterate an idler as any one on board. This kind of life would of course be impossible any where but in the tropics. Here however, the 
climate, an eternal spring, enervates the most robust and active, and with its gentle breezes and beauteous skies, brings one into a half dreamy languor which is delicious. After I had ceased to long for bread, and my stomach became reconciled to boiled rice instead, I enjoyed the life exceed. ingly, and was not long in forming a resolution to make these latitudes my cruising ground, and in case I found it comfortable, the Mauritius my home.

I was now approaching the Island under cir. cumstances very different from those in which I had visited it before. Then it was in an English ship, and as a British sailor, with all the helpless misery of a British tar cast ashore in a foreign port, where ships and victuals are alike scarce. Now, I had at length gotten into a French vessel, and among those who were natives of the place. And although, pecuniarily, I was worse off than before, I cherished a hope that the native vessels would be henceforth open to me, and reveled once more, in anticipation, in the glorious voyages to the out of the way nooks and corners of this part of the earth, which I should here have the opportunity to make.

Meantime we were slowly sailing on toward our destined port. As the wind was steadily ahead, wo had taken a long stretch to the East, and were now on the landward tack. After a forty days passage the high peaks of the Isle of France at length hove in sight in the blue distance; and twe 
days sailing through water more limpid, and with a sky more clear, and breezes more genial and soft than even those which had been vouchsafed ns during the passage, brought us to the narrow mouth of Port Louis harbor.

Who shall attempt to describe the glories of a landfall in the tropics? My pen is not adequate to a delineation of the beauteous boldness with which the outlines of the volcanic peaks are thrown in deep, deep blue against the distant horizon, or the glorious golden effulgence in which they are enveloped as the sun sets behind them: And who can do justice to the serene purity of the air; its genial mildness both night and day; the absence of harshness in every movement of the sea, as it sweeps in peaceful undulations toward the setting sun?

The breeze which fans the dreamer's brow comes as though some one laid his hand in kindness there. The waves which break under the bow, break softly. The spray which ever and anon falls upon deck, falls in refreshing showers. The wind which fills the sails blows gently; and the very ship seems, in unison with the scene, to glide along over the waves, no longer meeting and cleaving the waters with the stubborn shock of enemies in battle, but parting them asunder softly, as some good natured giant would make his way through a crowd of little children. The sabbath stillness is broken only by the harsh scream of the tropic bird as on snow white wing he sweeps past, landward, or darts beneath the wave in search of prey. 
And now scarce has the last golden ray of the departing sun gone down behind the distant moun. tain tops, when night conceals the scene as with a huge black cloth, through which shine myriads of brilliant stars, brighter by far than ever rejoiced the vision of him who dwells in northern lands "The eyes of God," whispered the mate to me, as I reclined upon the forecastle in silent contemplation of the change.

The entrance of Port Louis harbor is quite narrow, the ship channel being scarcely wide enough to sail up with a fair wind. And as the prevailIng wind blows out of the harbor's mouth, steam. ings have been found necessary to tow vessels in. At early daylight one of these little boats, there fore, took us in tow, and we glided rapidly up through tiers of large vessels securely moored head and stern, and with their top-hamper on deck, to present as little resistance as might be to the hurricane winds which occasionally sweep this latitude.

At the upper end of the harbor a basin, known as the canal, has been built for the accommodation of the small traders and bullock droghers: and among these we now anchored, sending our atern moorings ashore by large mooring boats, shich are held in readiness for this service bv . de captain of the port.

Once moored, the topgallant and royal yards nnd masts were sent upon deck and the topmasts 17 
and topsail-yards made ready for a speedy descent Then the hands had time to greet old friends who were fast crowding alongside or standing upon the shore waving handkerchiefs, and hailing in barbarous French. Had we now had English 01. American officers, but little time would have been lost in such pleasures. Preparations would have been instantly begun for sending our cargo ashore. But here the balance of the day was given for communion with friends, and to-morrow was declared time enough to begin work.

I alone had no friends to greet me, no one to rejoice in my return, no heart to beat quicker at sight of my bronzed face, by this time of nearly as dark a hue as many of my shipmates. And as joyful faces showed themselves over the gangway, and supplies of fruit from the shore proved the heartiness of the welcome which kind friends were giving the returned voyagers, I began in the selfishness of my heart mentally to find fault with all about me, and more than half wished I had not come to Port Louis.

But I was not doomed to remain friendless. As I sat apart, upon the topgallant forecastle; feeling, and I dare say looking very dreary, abrown Hebe approaching me, inquired, in bro. ken English, "You got no friends, Jack?"

"Not a friend," said I, in a gruff tone, as not thinking it desirable to have my loneliness com mented upon by strangers. Watching me rather 
dubiously for a noment, she held out her nand, and said in a voice full of serious kindness, "Well, I be your friend, Jack."

I did not put my arms round her neck and kiss her, as I should have done had I followed tke im. pulse of my heart. But I thanked her deeply for all the sympathy which was expressed in her simple words, and in her yet more child-like countenance. Hailing a boatman who was standing at the gangway, she bade him bring to us some fruit which she had in his boat, and over this and my dinner of boiled rice, Angelique and I sealed a friendship which lasted during my seven month's stay upon the island.

She had come on board to see her brother, who had sailed as carpenter of the vessel six months before. He had been drowned on the outward passage; to which untoward accident $I$ owed my ready acceptance by the captain, at Mahé, as well as, I suppose, the sudden friendship Angelique had contracted for myself.

"Poor Charles," said she, while tears filled hor eyes, "somebody else will feel as sorry as I do, when she hears of his death. But Marie will not be long away from him."

She was overjoyed when she learned that my name was also Charles, and in the simplicity of her heart at once pronounced our meeting Providential. While we were yet talking-she eagerly laying out plans for my stay on shore, as though we had known each other for years- the captain 
approached. He knew her, and had been the first to inform her of her brother's death. He smiled as he listened to her prattle, but entered heartily at her plans, and at once promised that if I rould stay on shore he would give me employ. inent, for a time, in sailing a boat between the town and his plantation, which was situated on a neigkboring bay. This proposal met my views. and I hastened to express my gratification. It was therefore arranged that I should remain on board till the cargo was discharged, and then take up my residence ashore in a small cabin belonging to the captain.

Having arranged these matters to our mutual satisfaction, she returned on shore to condole with Marie on their mutual loss, while I spent the balance of the day in the re-perusal of Bernandin St. Pierre's delightful story of Paul and Virginia, the scene of which, he who has read it will remember, is laid in the Isle of France; Tombo Bay, where Virginia, on her return from France, was shipwrecked, being, singularly enough, the locality of my captain's plantation.

On the morrow we commenced discharging our cargo of horses. They were noble little ponies, but rather wasted from a long passage in our illvectilated lower deck. They were hoisted out by a strap fastened about their middle, and being securely haltered, were made to swim ashore, a boat going with each to support and guido it. Arrived once more on dry land, the grateful 
animals scarce $y$ knew how sufficiently to express their joy. They capered and caracoled, neighed, and rolled upon the ground, in the exuberauce of their joy. I was told they were of the Arabian breed, although they were brought from the Aby sinian side of the Red Sea. They were firc, plump, lithe, and exceedingly high-spirited, as 1 had occasion to notice when they had again zesovered their strength and flesh.

Horses are not raised on the Island, but are brought.hither from various parts of the East, principally from the ports on the Red Sea. Neither is stock raising pursued as a business. I was told that the climate is unfavorable to its success. Cattle are brought from the adjoining island of Madagascar, and from the coast of Africa. These branches of trade give employment to a large number of vessels owned or sailing from here.

On the third day I was paid off by the captain, who gave me forty rupees, $(\$ 20)$, in consideration, as he said, of my having been very useful to him. Arrived on shore, I was welcomed as though I was an old resident, and in a short time was established very comfortably, Angelique, who proved a dear good girl, providing as carefully for my wants as though I had been really her brother.

In a few days I was placed in command of Captain Lepelletier's boat, and with a little Malabar boy as crew and to show me the way, we sailed down the harbor As we glided slowly over the 
smooth water's of the outer roads, the steady breeze scarce filling our sail, I took out my now never failing Paul and Virginia, and with tho lofty peak called Peter Botta heaving its griant head into the air before me, read over again the story of that fatal shipwreck, the scene of which, the bay of Tombs, (Tombo Bay), as it is still called, now lay before me. The engraving on the page opposite this is an accurate representation of it. Here, when in the dark, stormy night Vir. ginia's vessel missed the entrance to Port Louis, her captain sought safe anchorage, but was thrown upon the breakers. It was to me a realization of romance. Every shoal in the bay, as we sailed past it, every palm tree on the shore, every peak, towering in the blue distance, all were part and parcel of the story, the most charming of all tales of true love.

As we approached the landing, the white marble monument erected in memory of the lovers, and over their supposed graves, was seen through the green thicket of bananas and palms. Soon I trod a ground sacred to all true lovers, and witi book in hand, wandered about the beach endeav. oring to fix upon the spot whence Paul leaped into the flood to the rescue of his Virginia.

I found that although my little Malabar boy knew but little about the localities, the natives who had charge of the farm had all the particulars at their fingers' ends. They were delighted at the lively internst I took in the story, and 
pointed out to me every part of the beach or shore that was connected with the untimely fate of the lovers. Having surveyed all, and talked the story over in broken English on their part, and worse French on my own, we adjourned to the house, an ancient wooden structure, looking as though it might have stood there at the time when the bay firstreceived its present name. Here, while the Malabar servants of the farm were unloading my boat, a repast of delicious pine apples, mangoes and bananas was served up for me, and the entertainment finished by the introduction of a huge bowl of eau sucre, (sugar and water), from which each in turn took a long draught.

I wandered about the rocks on the shore until the turn of the tide, and then launching the boat, proceeded on my return. The wind was light, and the tide swept us some miles seaward before we arrived opposite the harbor's mouth. From there I had leisure, as I reclined under an awning in the boat, to view and admire the grand abruptness with which the volcanic peaks seem thrown up.

Peter Botta, although the most ceiebrated, is bJ no means the highest of these peaks. It acquires its celebrity from its singular shape, terminating at the top in a huge knob or ball, which has been ascended but twice since the island became known to Europeans. The first ascent was made by a Dutchman, from whom it derived its name, Peter Botta. He was seen standing on tbo 
summit, but was never heard of afterward, and probably perished in the descent. The ratives believe that his spirit still haunts the peak and its immediate vicinity. A British naval officer made the second and last ascent, with the assist. ence of a company of seamen. The party passed the night upon the mountain, some upon the shoulder, and two or three sleeping uneasily upon the narrow top of the ball. They descended the next morning, after witnessing a most glorious sunrise, and planting the British flag upon the righest point of the ball, as a memorial of their visit. This flag and staff have long ago been blown down by the hurricanes.

Mauritius, or the Isle of France, (it is equally well known by both names), was discovered by the Portuguese, in 1505. The Dutch took possession of it in 1598. Few if any traces of their government or settlement at present remain, with the exception of the name, Mauritius, which they bestowed upon the isle in honor of their prince, Maurice. It came under the French flag in 1721, and from that time till its capture by the British, in 1810, was in their possession. These were, from all accounts, the best days of the island. It seems during this period to have been a moderu Arcadia, the abode of a peaceful, inoffensive and somewhat indolent people, who tilled the ground or sinded their flocks, unambitious of wealth or distinction, and unmoved by the quarrels which rent the civilized world. Under the British rule 
it is gradually becoming a thriving business place, and its commercial im portance is Jearly increasing.

The French used to procure their slaves from the neighboring island of Madagascar, and the present black natives of the island are the descer.dants of these slaves. The British emancipated these, and as their descendants will no longer till the ground of others, but rather live contentedly on their own little patches of soil, eking out a scanty subsistence, with little labor, the govern ment now annually imports numbers of Hindoos principally from the Malabar coast, who take the place of the former slaves. These poor people engage themselves for five years. They labor for from four to ten rupees (two to five dollars) per month, and are treated much worse than slaves. In Port Louis, extensive grounds and buildings are set apart for their lodgings when first arrived. Here the planter or citizen in want of servants comes to engage them. They are chosen, and whether they desire it or not, must go with their new masters, on such terms as are customarily given on the island.

Unused to the severe labor which is exacted of them on the sugar plantations they soon becorce low spirited, and not unfrequently commit suicide. Great numbers desert from the plantations and conceai themselves among the mountains or in the town. Policemen are constantly upon the watch for these runaways, and when a Ma'abar is 
seen on the streets of Port Louis, whom a police. man has reason to think a deserter, ho is forced to produce either his free-papers or a permit or leave of absence from his master, and in default of both of these documents, is at once imprisoned and advertised, in order that his master may claim him.

On the plantations the lash is freely used, it having been found that without this the requisite amount of labor can not be extorted from these poorly paid, ill fed and naturally indolent pcople. It will be easily conceived, that their condition is not therefore any better than one of slavery, for the time being, and taking into consideration the false pretences under which they are allured to leave their native land, and the hopes held out to them of being able, at the end of their apprentice. ship, as it is called, to return home in easy circumstances, their condition is much worse, and their treatment a greater wrong against humanity.

Comparatively few ever return. Many die before the expiration of their term of labor. Others engage in business, numbers of them keeping small stores for the sale of provisions and fruits to the poorer classes of their countrymen who live in the city. And others yet labor about the town, or peddle vegetables and goods about the streets; this earning a scanty subsistence: part of which they are again forced to surrender to the government in tho shape of a license to pursue their calling 
One of the suburbs of Port Louis is settled principally by these people, who live contentedly on their small means when they once regain their liberty. A walk through Malabar town about sunset, when the heat of the day is relieved by the cool evening breezes, will give one a much more favorable idea of the Hindoos than will be gotten from the accounts of their English masters. Here each family gathers about the door of its hut and listens to songs, or the music of the mandolin, the women talking, the men silently smoking their narghilly or hubble-bubble. Maidens dance upon the green sward, and little naked children play about the doors. All is a scene of quiet, peaceful enjoyment, which will convince any one that, indolent as these people doubtless are, and intractable as they are said to be on the plantation, when left to themselves they are inoffensive, and have the elements for making of them good citizens.

The black natives of the island do not bear so good a character. They are exceedingly lazy, and much inclined to rowdyism and thieving. They are not numerous, at least about Port Louis. The better class of them work as stevedores on board the vessels, or are engaged as porters and laborers on shore. An inconsiderable number sail in the country vessels.

The Chinese, as mentioned in an account of my first visit to this place, are the most thrifty of the lower classes. They are seldom laborers, but 
keep the groceries and groggeries of the town and have a keen eye to all kinds of trade. Frugal, not too honest, and exceedingly clannish, they are to a man in comfortable circumstances. It is 2 common remark in the Mauritius, that a Chinese beggar was never seen there. If a poor China man comes to the colony, his countrymen give him employment, and place him above want. They do not intermarry with the other races, but procure for themselves wives from China.

A singular story is told of their once entering he vault beneath the bank building in Port Louis, ly undermining the street leading to it. A large amount of bullion was abstracted ere the plot was discovered; and for some time no trace could be found of the robbers. The Chinese burying ground is below the barracks, in the lower part of the harbor. Thither, one morning, just at the break of day, a company of Celestials were seen conveying a coffin. A Chinese funeral was nothing strange; but the sentry noticed that the body seemed to be remarkably heavy, causing a frequent stoppage and change of bearers.

As the guard was relieved, the man on duts remarked, jokingly, that a fat Chinaman was beilig taken to his long home. To the sergea it the movement seemed suspicious, and he at once pro. ceeded to the funeral cortege, who at his coming precipitately fled, leaving the suppositious corpso to its fate. Upon breaking open the coffin, instead of a dead Chinaman, it was found to contain the 
greinter purtion of the stolen bullion, which was thus being conveyed to a safe resting place.

Besides the races already mentioned, Port Louis has samples of almost every Asiatic, and many European and African nations, all of whom find sccupaticn in various departments of its now active commerce. This commerce is mainly in the hands of the English and the French creoles. The French language is universally spoken-as much so indeed as though the island still belunged to France.

The merchants mostly have their dwelling houses on the outskirts of the city, and many of them have built upon the sides of the mountains which surround Port Louis. There the white houses may be seen perehed upon abrupt crags, and peeping through thick groves of beautiful trer:a. 


\section{CHAPTER XV.}

A modohina Ceremony-A Sailor's Grave-I turn BoatmanLife in the Isle of France-Seeking Employment-Jou Rodg. ers-A Bullock Drogher - Tamative Bay - The place of Sculls_Hump cattle - Our return Passage-Taming wild Cattle-Sancho-His docility-Meeting Ashore-Difficulty of leaving so warm a Friend-A Wedding.

ON the first Sabbath after I came ashore $\perp$ was witness, in my capacity of captain of a boat, to the performance of a very touching ceremony. I had been informed on the preceding day, by Angelique, that she and certain of her friends expected me to ferry them across the harbor to the city cemetery.

Accordingly, at early dawn I was summoned, and repairing, in company with my little Malabar assistant, to the boat, found her already laden with fourteen or fifteen young girls dressed in pure white, ard each with an armfull of flowers. We hoisted our sail, and just as the sun rose glided gently across the smooth surface of the bay, toward the western headland. Several other boats, freighted like mine, were ahead and astern of us, bound on a like errand with us. Low, plaintive songs resounded from the boats across 
the still waters of the bay. The scene was very beautiful.

Half an hour's slow sailing brought us to the opposite shore, where my passengers debarked. I acrompanied them to the burying-ground near by. Here the flowers each had brought were strew $r_{i}$ over the graves of departed relatives and friends. The mounds and tombstones were nicely cleared of all rubbish, and their floral offerings were placed at the head and feet.

As the maidens, in their white and flowing drapery, glided noiselessly yet cheerfully from grave to grave, doing kind offices to the resting places of their friends, and scattering beautiful flowers over their remains, they seemed like a chorus of blest spirits come down to summon loved ones to their homes. Occasionally a low sob or wail from some mourner for the recently departed, would break upon the ear, but otherwise all was silent as the graves we wandered amid.

In looking among the mounds by which the whole surface of the old cemetery was broken, I came upon a rude wooden cross, worm eaten and weather beaten, fast mingling its dust with his who lay below. Upon the horizontal piece were. cut in rude letters, probably done with a sailor' jack-knife, the words,

* Here, a sheer huik, lies poor Tom Bowling."

It was the last resting place of some poor weather-beaten sailor who had found here, far 
away from home and friends, the peace he had sought in vain during a hard and perilous life. $\mathrm{He}$ too was thought of by some kind flower dis. penser. The dead leaves and rubbish had been nicely swept away from the sod-covered grave, and two beautiful flower wreaths lay upon it. Poor fellow-in all his lonely seaman's life he had possibly never met with so much kindness.

On inquiry I learned that it was customary every Sunday morning thus to decorate the graves of friends and acquaintances, the boatmen of the harbor on these occasions doing volunteer service, to aid the undertakin $;$.

My life was now for some time very much hap. pier than it had been for a long period past. I was free: and the remembrance of my slavery on board the whaleship was yet sufficiently vivid in my mind to make me appreciate very keenly the new liberty. I was, for a sailor, pleasantly situated. My work was light and pleasant, the pay regular and sufficient to support me; and my associates, if not very intelligent, were yet good, and wellmeaning toward me.

Lngelique, who proved a noble girl, seemed sin. gularly enough to have bestowed upon me all the affection she had entertained for her deceased b1 other. She not only interested herself in my little affairs, but prevailed upon her lover, who was captain of a little coasting schooner, to introduce me to the captains of the French bullock droghers, in order that I might, when onee 
more ready for sea, have no difficulty in sbtaining a berth on board a country vessel. She had resolved that $I$ should become a settler in the country, never to return to Britain or America.

My occupation as boatman continued four weeks. By this time I was able to make for myself another opening. I entered a stevedore's gang, and tugged manfully at sugar bags all day, content to returu to my nicely fitted room at night, the richer by two rupees, and with a certainty that no storm, however severe, could disturb my sleep.

But soon "the demon of unrest" again stirred within me. To be sure, the life I led pleased me to a certain extent. So well, indeed, that I too shortly began to entertain the idea of spending some years, if not the kalance of my life, in the Mauritius and the Indian seas. Once in a while, however, the thought would arise, that I was not surrounded by just such society as was most congenial to me, and that in the mode of life I thought of adopting, there was nothing improving or elevating.

But eight years at sea had pretty effectually scotched any aspirations for a higher position which I might once have entertained. Life-the sailor's life, the only one of which I now had any nell shaped idea - seemed at best but a trouble. some and tiresome struggle. And so I brought myself to think the vegetative existence of man upon an out of the way place like the Mauritius. at least better than a more toilsome life in more 
civilized parts.. Some indolence, some hopelessncss, and a vehement desire for once to enjoy life, probably brought me to this conclusion.

And to this will come every one who takes to. the sea for a livelihood. It is very well to thin. rize on the ennobling and elevating character of a perilous life like that of the seaman. It is true, beyond doubt, that in those scenes where he contends with and overcomes the powers of nature, his sprrit, let it be sunk low as it will, is refreshed and elevated. But the excitement once over, the life is altogether too commonplace, too void of purpose to keep up a manful spirit. Its degrada. tion is too great, its associations too wretched to leave the aspiring soul room for a better hope.

And so the sailor boy who has leaped into life with a trustful determination to do and dare, and deserve at least the good will of his fellow men, emerges into manhood with all of good within liim, not killed, but fearfully crushed beneath the veight of evil and down-dragging associations. And so-I began to look for a ship, content to ỏn as others did, satisfied to accept the place apparently determined for me by fate, and willing to make the best of it.

Wanting a ship, and getting one, seem to be sntirely different things in Port Louis. My friends the French captains were, unfortunately for me, all gone on their voyages, the regular sea. son for starting on a long trip to the Red Sea having arrived while I was still boating. Work 
was so longer to be obtained in sufficiency to make me conterted, and so, rather than wait for better times, I essayed to procure myself a berth in some one of the British country ships which traded to the Mauritius.

Day after day I dressed myself in my best, and presented myself to some captain or mate to ask for a chance. Day after day I walked the mole, looking longingly at the departing vessels, and listening with sinking heart to the cheerful songs of those who had what I wantedemployment.

To be sure, there were ships for England. But thither I would not now go. The difficulties in the way of remaining in the Indies only endeared the prospect to me. And my determination in this regard was now strengthened by that of a friend whom I had found on shore; a noble fellow, between whom and myself there shortly existed a bond warmer than is common even amung sailors.

Poor Joe Rodgers had already several years' experience of the Indies. He owned it to be a dog's life.

"Hard work, poor pay, and you have almost to beg for a ship, when you once get adrift, Charley," said he to me. "But I dare not return home as I am."

He too was an American. He too had set out to sea with romantic notions of a life which he was now old enough to view in all its cheerless, hopelese 
degradation. To return home was the strongeat desire of his heart. But to return home penniless, after years of hard struggle - to be sneered at by those wiseacres whose advice be as a boy nad scorned-to go back to his native village not only having done nothing heretofore, but w: th the consciousness that he was now worthless for any other life than that which had grown to be a part of him-this he could not do.

"And so I guess we'll have to rough it in the Indies as long as we can stand it, and when it grows unendurable, Charley, a trip to Batavia will finish poor Jack."

At first, while yet the cheerful jingle of a few rupees in our pockets kept us in spirits, we could think of nothing but sailing together. But ere long it became evident that even this poor pleasure would be denied us, and we would be com pelled to look for separate chances. One day I boarded a vessel bound to Arracan, at the head of the bay of Bengal. The captain wanted a seaconny, and agreed to take me. There was no other chance. Joe and myself would have to part.

With a rather heavy heart I returned to the shore, to teil him of my questionable luck. The royage was good, but we did not want to part. We talked matters over. Joe had been some weeks longer on shore than I, and I felt that to bim of right belonged the first chance, if we were to be parted. Accordingly, I proposed to him to 
go to Arracan, while I looked for another vessel. Arid he, who was nearly at the end of the littlo money he had brought on shore with him, relno tantly accepted my offer.

On the following day, the captain stating him. self willing to make the exchange, Joe took his things on board. The vessel sailed, and I saw his face no more.

Two days afterward I procured a berth as seaconny on board a Tamatave bullock trader. The news had just arrived at the Isle of France that we despotic queen of Madagascar, who had for a long time kept every trading port on the eastern side of her island hermetically sealed to foreign vessels, had at length been induced to open the harbor of Tamatave to trade.

The Isle of France is entirely dependent on Madagascar and the African coast for beef-cattle. None are raised on the island, which is devoted almost entirely to the culture of sugar. The Madagascar coast is only three days' sail distant, while the nearest point on the African coast can not be reached under twelve days. Of course the Madagascar trade is of great advantage to the Mauritius.

All was at once bustle and business among tho bullock traders, on receiving the news cf a re. newal of trade. Our vessel was among the first. to reach the newly opened port. The trade winds swept us down in three days and a half. We fourd cattle enough on the white beach before the 
town to load a dozen vessels. The natives were moderately civil, but evidently not at all cordial. But it was their cattle and not themselves we warited; and so, the business being conducted on the cash and one price principle, there was but little difficulty in our intercourse with them.

The large hump cattle were brought alongside, one at a time, in native canoes. We hoisted them in and bestowed them in the hold, in stalls prepared for them.

On the second day after our arrival in port, I, with the other seaconnies, took a walk up to the town, which is situated, in Madagascar fashion, upon a hill, a quarter of a mile from the beach. It consisted of an assemblage of most wretched looking huts, dark and poorly fitted within, and unprepossessing without. A mud wall surrounded the place, and with a moat, formed its chief defense against an enemy.

Over the gate at which we entered, twenty human sculls were ranged in a semi-circle. These, now bleached by several rainy seasons, were once the property of some English sailors, who fell into the hands of the natives while making an attack upon the town some years before

When news reached the governor of the Mauritius that these barbarous trophies were yet dispiayed before the eyes of British and French traders, a reinonstrance and request for their deliverance into the hands of a British agent, for decent burial, was despatcked to the Madagascar 
chiefs who ruled that part of the coast. The reply from the queen was, that the sculls must remain where they were placed, and that if British merchants and seamen found themselves injured in feelings by this display, they need not come there to trade. As Tamatave is important on account of its nearness to Port Louis, and the quantity of bullocks brought there from the interior, it was resolved to pocket the affront and con. tinue the trade.

We remained but three days in the bay. Our passage to Port Louis lasted seventeen days. The fair wind down was of course dead ahead when returning, and we were forced to beat to windward every inch of the way.

It is singular how quickly on board ship the most ferocious animal becomes tame and docile. The cattle of Madagascar are noted for their wildness and savage temper. Yet we were scarcely a week at sea ere every one of the one hundred and twenty which formed our cargo knew the voice of his attendant, and was perfectly tractable and obedient to command.

Before we reached Port Louis many of the finest. animals, who were much caressed by the crew, grew to know individual visitors to their places of confinement., I remember well one noble fel. low, who had killed a Madagascar man on shore befure we took him on board, and who for two or three days gave the cattle tenders more trouble than any half dozen others. He was as fine 
a specirnen of his kind as ever I saw, and uxcited universal admiration when we got him on deck.

Well, this savage fellow gradually came under the influence of man, and at the end of the first week out was already as tame as need be. Ha was my favorite. I frequently walked to his stall with a handfull of salt, or an armfull of feed. And shortly he would low gently at my approach, and if I stood near enough to him, would hold out his great head to be scratched, permitting me to handle the horns which but a few days before had impaled a Madagassy. He could distinguish mo from all others, even at some distance, and would manifest pleasure even at the sound of my voice. Many of the cattle had names given them by their especial friends among the crew. Thus the Malabars had two favorites whom they called respectively Abdallah and Mohammed Ali. I called my huge friend, Sancho, and by this name he was shortly known to all on board.

When our cargo was landed at Port Louis, I took a farewell of Sancho. But some days afterward, while rambling over a beautiful pasture some miles from the city, I unknowingly approached a herd of cattle. I was abcut to retreatfor the hump cattle quite frequently attack strangers-when a mighty animal came running toward Ine, head down and tail high in air. I thought my end was nigh, and looked about rather de. spair:ngly for an avenue of retreat, when I recognized in the advancing brute my old friend 
Sancho. Somewhat reassured, I awaited his approach. I should have run, had there been a place of security at reasonable distance. But from my position to the nearest tree or fonce was such a distance as that in a race I would certainly have been overtaken. When Sancho came within a short distance, I spoke his name. At this he grew almost frantic, and began such a series of ungainly capers about me, that though in imminent fear of being crushed by him in his elephantine manifestations of joy, I had to laugh heartily

When he was a little quieted, I advanced and stroked his bushy head and handled his horns, whereat he seemed as pleased as a child would be at the caress of a friend. The other cattle meariwhile gathered around at various distances, suspiciously watching my movements, and evidently much at a loss to know the import of Sancho's actions.

After paying my huge friend such attentions as I thought would be mutually agreeable, I turned to leave. But this motion he strenuously resisted. Turn which way I would, he got before me, and insisted on further attention. The nearest fence was some hundred yards off, and I saw no way of getting there with his opposition. When I persistently moved on, he would recommence his huge gambols in such close proximity to my person as to make me glad to stop. He would toss his head and leap about me madly, shaking his ungainly hump, and making altogether 
unmistakable demonstrations of the pleasure ho found $n$ my society, as well as of his determination not to forego that pleasure for some time. Moreover, the balance of the herd, nearly a hunlred huge bulls, followed implicitly the motions of $\mathrm{my}$ friend, and threatened by their sympathetic rejoicings to become exceedingly troublesome.

I was soon aware that a good degree of generalship would be necessary to get safely away. I plucked some grass, and Sancho, appeased, goodnaturedly ate it from my hand. I moved slowly on, gathering grass as I went, and thus keeping nis suspicions at rest. In the course of half an hour I found myself by this means within a short distance of the fence. Picking out a part easy to leap over, I gradually approached it, and finally, with a quick spring placed it between myself and my troublesome friend.

This violation of confidence aroused his fury; and with glaring eyes and angry toss of the head he pawed the ground, and bellowed hoarsely at me. I, meantime, not knowing but he might attempt to follow me even over the fence, made good headway toward a turn in the road, where I should get out of sight, and I hoped out of mind This was my last visit. A week after, with many compunetions of conscience, I ate a steak cut from Sincho's fore quarter.

Upon my return to Port Louis from Tamatave, my good friend Mademoiselle Angelique was married. I attended the wedding, as her adopted 
rother, and was much delighted at the charming simplicity with which everything was conducted. Most of the French Islanders are Roman Catholics. Angelique and her intended husband, Captain Alexandre, wer nominally so; and of course the marriage ceremony was pronounced by the Priest, at a little church situated in the rative quarter. The bride and groom walked together from the house of the former, to the church, preceded and attended by a company of young girls, dressed in white. These strewed flowers on the way, and sung verses suited to the occasion, to a simple and beautiful air.

At the church door they were received by such of the bridegroom's male acquaintance as had . been invited to attend. The attendant maidens entered the church, singing and casting flowers about, until they reached the altar, where they formed in order on each side, leaving a middle space for the happy couple. These took their places, and the male friends formed a semicircle outside of all. The ceremony was then performed by the Priest. I presume it was the common ceremonial of the Roman Church. Near its close one of the maidens handed to the bridegroom a beautiful wreath of white flowers, which he placed upon the head of his bride. She was dressed in pure white, with a small gold cross suspended by a thin gold chain from her neck. The bridegroom was clothed in a check shirt, and 
handsosne blue jacket and trowsers. They wore a fine looking couple.

At the close of the ceremony, flowers were show. ered down upon the lridal pair until I trought they would be smothered under the load. Then, amid another and more solemn cliant from the attendant maidens, the party left the church; the newly married couple walking hand in hand like little children.

All now walked to the groom's house, situated a little distance in the country. Here some matrons and old men were in waiting, with presents of necessary household articles, of no great value, but altogether helping very materially to make the young pair comfortable. As each one presented his or her gift, a kiss and a graceful "merci" from the bride was given as reward. An ample supply of fruits and wine was then laid out on mats upon the green, beneath the shade of some cocoa nut palms, and here the day was passed in quiet enjoyment, the evening closing with a dance upon the green sward, to the music of a inost wretchedly played guitar. 


\section{CHAPTER XVI}

Hes Annie-Her Captain-I ghip in her-Our Crew-A Clip. per's Forecastle-Sleeping Dis-accommodations-Steering"Humbugging"-Planning a Mutiny-Counter PlanningThe African Coast-Algoa Bay-The Anchorage-Surf-boats -Cape Boors-A South Easter-A Double Wreck-Lloyd's Agent.

UpoN my return from Tamatave I left the vessel I had sailed thither in. She was going to Calcutta, and thence to London. I desired to go nowhere just then, without having at least a fair prospect of being able to return to the Isle of France. I was so fortunate as to obtain in a few days, a berth in a little Scotch brig, bound to Algoa Bay, on the African Coast.

The Annie-that was the brig's name-was a beautiful little craft of about two hundred tons burthen. I had often heard old sea dogs te:? if resisls that they loved almost better than them. selves. This was such a one. Her long, iow, gracefully curving hull, her sharp, keen bow, and clean cut run, her taunt, tapering masts, and vast yards, almost heavy enough for a vessel of twice her size, thr jaunty, reckless, yet neat air of every. 
thing, alow and aloft: all these tended to make her the delight of a true seaman, proving, as they did, that she was a clipper in every sense of the word.

She came into port on the same day with ns, and as she easily glided past us, with a light, breeze, all hands congregated on our deck to look at and admire her. I think I never saw so perfect a little craft, or one so consistently rigged and fitted throughout. To my rather matter of fact spirit, it had always seemed an absurdity to love a vessel. But this time I was forced myself to entertain the feeling. She was a beauty, and as $I$ stood in silence examining her matchless hull, no line or curve of which, but was artistically true, I. owned, with an inward smile, that this was really a case of "love at first sight."

"That's the vessel I am going in next voyage," said I to one of the other sea-connies,

"You'd better keep out of her. Her captain is the meanest Scotchman that ever lived. And moreover the mate is his brother. The man that ships in her will smell brimstone, I can assure you."

"Brimstone or no brimstone," thought I, "that's my ship, if I can prevail on the captain to carry me."

On farther inquiry I learnt that the Annie's Captain was indeed a tyrant, and that the little beauty never carried the same crew two voyages. 
Nevertheless, the vessel was not to be driven from my mind, and I determined to risk at least one trip in her.

I boarded her the following day, and heard from her crew that they were all going to leave.

"No white man can stand such a wretch two voyages," said an old tar to me. "You have.no thought of going in her, have you, boy?"

I hesitatingly acknowledged my desire to make a voyage in the Annie.

"You're a fool-that's all. But you're in love with the little craft."

"Small blame to him," spoke up another of the crew. "Sure, every one of" us was in the same fix this day two months ago."

"Well, she's a darling," said a third, with a sigh, "but the master is the devil."

I could not find out in what respect the captain resembled the individual last mentioned. Her crew were going to leave; and with a jealousy. somewhat characteristic of British seamen, preferred to let me learn by experience the disagreeable traits in the captain's character.

So I determined not to be frightened at shadows, but being able to do my duty, to ship in her, fearless of consequences. When the captain made his mpearance on deck, I walked aft, and asked him for a berth for his next voyage.

"You're a Yankee lad, are you not?" he asked. I replied in the affirmative.

"Hav you heard any thing about me ashore? 
I hesitatingly replied that he was scarcely in the odor of sanctity with those who had sailed with him.

"I suppose not. But if you can do your duty, you need not be afraid of the Annie. If you can't you had better never look this way again. If you want me to ship you, come aboard to-morrow morning at 10 o'clock, and sign the articles. The wages are two pounds sever and sixpence, and small stores."

All this was said in a Scotch way, which I could hardly understand, and I noticed that occasionally when he spoke a word to his mate, it sounded like anything else but English to me. But "what's the odds, so long as you're happy," thought I; and determined, no matter what was told me of the officers, to go at least one trip in the little craft. Accordingly, on the following morning I signed the Annie's articles, binding myself to go " to Algoa Bay, or Port Elizabeth: thence to such other ports on the coast of Africa as the captain may direct; and return to Port Louis."

The vessel was to sail in five days, and her.erew was not wanted on board till the day before she I ft port. I had therefore some days before me, wherein to prepare myself for the voyage. I found that wherever I happened among the seamen then ashore, the news of my shipping in the Annie had preceded me. Various were the comments made upon this piece of rashness. Those who were well disposed toward me urged me to back ont 
Those who did not know me, except casually, chuckled with delight that "that Yankee fellow" was taken in. Captain McDonald, and his brother the mate, I found were well known in Port Louis, as a pair of arrant tyrants, to be in whose power might be justly thought a calamity. Even cap tain Alexandre, the husband of Angelique, urged me to back out from my agreement, and wait for a better chance.

But my mind was made up. Some one must go . in the vessel, thought I, and if any óne could stand it, I could. So I was shortly given over as an impracticable.

On the fourth day I rendered myself on board. I found the four men already in the forecastle, who were, with myself, to form her crew. They were a rough looking set.

"You're Yankee Charley, that lives up in Malabar town?" queried one, after we had taken a good look at one another.

"At your service."

"Where's Joe Rogers, that used to live with you?"

"He went to Arracan, in the brig Talliho."

"I wish he were with us. He's the best fellow that ever I sailed with. He's true blue."

"Well, young one," said the oldest of the crew to me, "you've heard about the officers of this little craft. They're a pair of bloody scoundrels, and we must show a firm front, or they will lead ns a wretched life." 
"Count me in," said I, knowing that a lotermi. nation expressed in few. words was best suited to the minds of British tars.

"That's right. If he's down on one, he's dow : on all; and if he attempts to curse ary one, curse him back, from the word go.

"The main thing," said another, "is to do our duty like men. Then if he growls, we shall be in the right."

I think if our captain had known what was going on in the forecastle, he would scarcely have been willing to carry us as his crew. Meantime, we made ourselves comfortable in our new home. Owing to the sharpness of the vessel, the forecastle was an exceedingly narrow hole, in which five men had just room to stand up together, but certainly not enough to sit down. Fortunately hut two of us had chests. The balance were old coast rangers, and kept their clothes in bags, which served for pillows.

Being the last one on board, I had a forward berth left for my use. This was so narrow that I found it, on trial, impossible to lie straight in it. My shoulders were broader than the berth space, and the only way in which I could rest was by lying upon one side.

"You'll have to get out to turn over, my fine fellow," said one who had been watching me while adjusting myself to the space.

And this proved to be true. Whenever, during my sleep, I got tired of lying upon one sirle, I was 
obliged to get out and carefully crowd myself in on the other.

"That comes of going in a clipper," remarked one who was as unfortunate as myself in his sleeping place.

The first day on board was passed in idleness. After washing the deck, we were told there was nothing more to do. So I sat down to a book, while my shipmates played cards, smoked, and talked over old times. They were a tolerably hard set; and I thought, not without satisfaction, that our officers would gain but very little by any but the most civil conduct toward us.

At daylight on the following morning, we cast loose from our moorings, and dropped down the harbor. Once clear of the shipping, all sail was set, and we glided quickly seaward.

"Send Yankee Charley aft, to the wheel!" shouted the skipper.

I proceeded aft.

"Keep her straight. She steers like a boat; and I count half a quarter of point a good bit out of the way. If you watch her closely, she need not go off her course at all."

Now a quarter of a point off, or to, is considered pretty good steering in most vessels. So that this narrowing down to half a quarter was by by no mears comfortable. Nevertheless, as I was always counted a good helmsman, I cared little for what the skipper said-content to rest up. on lazrels already won in that line. 
I found the little craft to steer very nicely-as indeed was to be expected, from her build. A spoke of the wheel either way, was quite sufficient to keep her along straight. But I never before saw any one watch the compass so closely as did our captain. He seemed to make this his sole business. If he was walking the quarter deck, he looked into the binnacle every time he passed it. If he was talking to the mate, he would stop in the middle of a sentence to ask how she headed "exactly." If he was obliged to walk forward, he kept his eyes constantly ahead, to see how muck. she swung about. And as it was necessary that he should sometimes-at meals, and during the night-be below, he had prepared himself for this by having the steering compass placed in the cabin sky-light, and having it fitted with a transparent card and bottomless box, so that by looking up from where he eat or slept, he could know as well us the steersman how she headed.

All this was excessively disagreeable. To steer is, under any circumstances, the most irksome task which falls to the lot of the foremast hand. It requires unceasing vigilance, and an entire concentration of thought upon one object-the vessel's course. The mere skill necessary to guide a ship is the least part of the accomplishment. With so quick motioned a little craft as the Annie, a constant watch was necessary, to keep her from shooting off her course. With this unceasing care, it was quite possible to keep her exactly up inn her 
course, as was indeed often done on this voyagethe vessel not swerving a hair's breadth, some. times for an hour.

But the slightest inattention was sure to be followed by a "now then, where are you off to now?" from the skipper; an unwelcome reminder that she was off her course.

Thus it came about that shortly the trick at the wheel was regarded as the worst of each one's labor, while the man who found it so convenient to sleep and eat and walk about under or in the immediate vicinity of the compass was rightly thought a tyrant.

This was only one way in which the exacting spirit of our Scotch skipper showed itself. His vessel was a clipper :

"She can sail," said he, "and it is my pleasure to have every thing done that will facilitate her speed."

So every morning at daylight, and every day at noon, and every evening, and sometimes (if he happened to be awake) at midnight, tacks, sheets, halyards, braces and bowlines were swayed home, thus keeping one watch on deck half an hour longer than necessary, besides forcing all hands to a labor which every one knew was not at all necessary. For so taut were the ropes sometimes. that it was actually necessary to ease them off again during the succeeding watch-only however, to be again swayed home when the watches were cbanged. 
In addition to this, the decks of the little craf were holy-stoned every morning for at least an hour : until we one night emptied the sand neces. nary to this labor, over board. After that the paint work received a double share of attention, and even the masts were scrubbed; while any spare time in the morning watch was devoted to brightuning up the brass-work, of which this daintily fitted little vessel had as much as many a frigate. All this kind of labor is irritating to seamen. They call it humbuggery. To work hard from daylight till dark, at the vessel's rigging or sails, where perhaps every bit of sea lore they may be possessed of is brought into service, would not be thought disagreeable. But to set a parcel of old tars at scrubbing paint-work, brightening brass rigging caps and capstan heads, and knocking rust-scales from the iron work, will produce mutinous thoughts sooner than any other course of treatment.

So it came about, that ere we were a week out, as I came forward from the wheel one day at noon, a plan was being discussed, by which we, the crew, were to take possession of the vessel, getting rid of the officers as best we might. The reckless fellows laughed heartily at my serious face when the project was bluntly laid before me.

"As for Jimmy" - the mate-"I can easily put nim over the taffrail any night when I am at the wheel, for the booby regularly goes to sleep when 
be has the midwatch upon deck," said a Scotchman, between whom and the mate there was a standing grudge.

"And the skipper wouldn't give us much trouble. Only bring the ressel in the wind once, and he'd rush right into our arms.

"And then just think that this little craft-and by all that's good, she's the smartest and prettiest little thing that ever I saw - just think that she'll be our own."

"Look out; here comes the mate," said I seeing that worthy approach. So the conversation was closed for the time. I did not sleep, that afternoon watch. I had sufficient subject for thought. It was evident that although the matter of a mutiny had been broached at noon in a kind of semi-jocular way, there was that in the hearts of somo which it would require but an accidental excess on the captain's part to fan into a flame of action. How to prevent this was now a matter for very serious consideration.

To withold my consent would perhaps have some influence on their actions-for although $I$ was physically the slightest of our crew, they had all somehow got a liking for me. But this would :ot answer all objections. After a couple of hours study, it finally occurred to me that the whole plan was certainly not yet matured, and I determined to hinder its farther progress, by showing up as clearly as I could its impracticability.

That evening in the dog watch, a young lad.wa 
sent to the wheel, and the rest of us congregated before the windlass to have another talk over the matter.

"You see, Charley," said our Scotchman, "the thing is as easily done, as turning over your hand."

"But what are you going to do afterward?" I enquired.

"Oh, we'll sail about till our provisions are out, and then run in to some out of the way place to get some more."

"Where's the money to purchase more?"

"That's a fact. I heard it stated at Port Louis, that our skipper always sends his money by another vessel. Having an agent at Algoa Bay, he don't need much."

"Besides which," suggested I, "if the Annie don't arrive at her port in proper time, you'll see some man-of-war brig after her in double quick time."

"I have yet to see the brig, or sloop, or frigate, that could catch the Annie, sailing on a bowline, or in fact, any other way."

"What do you propose to do with the brig, whon you have got her in your power?" I asked.

"Keep her or sell her, as may seem best."

"You can't sell her, for no one will believe yuu came rightfully by her, and who ever you offer her to, if rascal enough to buy her of you, would be also rascal enough to put you in jail till you gave a better account of yourself than you could do." 
"Well, we'll keep her."

"Yes, and be caught in her, and hung up to her yard-arms. Not I for one," here broke in a tall lrishman, who had not before said much.

"There's some fine spots among the South SeaIslands. Let us go for instance to Ocean Island in her, and there break her up, or wreck hes before we get in."

Now was my time to sum up the case; and drawing a long breath, I was about to commence such a setting forth of the whole matter as should show them the unsafeness, as well as the unsatis factoriness of any one of their proposed modes of action, when the sharp voice of the captain was heard, shouting-

"Do you hear there? Lay aft here, and sway up this topsail! The leech is hanging in a bight!" "Aye, aye, sir," sung out Scotch Jack; adding in an under tone, "Blast you, I wish you were at the other end of the halyards."

We swayed up the top-sail, then pulled hoins the top-gallant sheets, swayed up the top-gallar* sail, and finished with the royal.

"Now, we'll take a pull at the forward ha yards," said the skipper; who was never so well pleased as when he was bowsing taut a ropeor rather ordering others to do so.

After half an hour's straining and hallooing, every rope was again taut as a harpstring, and we were told that "that would do, till the mid watch." It was by this time eight bells; the 
watch was set, and all farther deliberation wa over for the night. I did not fear any precipitate action on the part of my evil-inclined shipmatco, Woll knowing that those who talk most in sucl matters are generally slowest to act. I trusted, besides, that the words of caution I had thrown out, would not be without fruit in their minds.

In this I was not deceived; for when, on the fol. lowing evening all hands were once more gathered on the forecastle, every one but Scotch Jack declared the execution of their project to be attended with more difficulties than they had at first sight thought.

I now determined to place all the impossibility of success before them in its strongest light. Accordingly, after listening for some time to new suggestions, and even throwing out one or two myself, I began:

"You can't sell the vessel, boys: that's clear. You can't keep her-that is equally plain. She's too pretty a craft to be broken up in the surf; and besides, if you want to go to Ocean Island or anywhere else in the South Seas, you have all been to Sydney, and have only to go there again and ship for the very place you want to settle-down in. As for the skipper's working up-we all owe him a spite, and the greatest satisfaction will be to give him and the mate a thundering beating, when wo get back to Port Louis. If ever he comes into Malabar town, he won't leave 't with a whole skin, if I know it.' 
With this piece, half of reasoning, half of brag. gadocio, I lit my segar, confident I had given a death-blow to our harmless little conspiracy.

"It's just as Yankee Charley says, boys, 'spoke one, after a long silence, during which all had evidently been chewing the cud of reflection. "It's not fit that British sailors should toss sleeping men overboard, or knock defenseless men on the head. It looks too much like a parcel of miserable Portuguese. But if either skipper or mate will fight me, man fashion, when we get ashore, I'll give them such a pair of black peepers as you won't find this side of London bridge, or Donnybrook Fair."

This was the last of what was afterward called "our pet conspiracy." Had our passage been a tedious one, I am not certain but that it would have been again revired. Happily, however, for all concerned, it lasted but fourteen days, and for three of these fourteen we were in sight of the African coast. It takes longer than two weeks to natch out a mutiny - a fact in ornithology to which, perhaps, our rascally officers owed more than they were aware.

We made the coast at some distance to the north of our port. Here, the African land, which I now beheld plainly for the second time, was high, and apparently barren-very unattractive indeed, and with its yellow sandy hills, realizing somehow, my conception of the Great Desert. As wo ap. proached Algoa Bay, the bluffs disappeared, and 
low islets and sand-banks took their plac,e- mak. ing the prospect yet more dreary.

The bay itself is wide and shallow. It affords but an insecure anchorage, and would not be frequented, were there a better one within a hundred miles. The town is situated on rising ground, facing the roadstead. Its white, clean looking houses present a very pleasing appearance. A fortress, called Fort Frederic, crowns a hill adjacent to the town. Fort Elizabeth is situated at the mouth of Baasheer river, which flows into the bay, near the town.

Algoa Bay is distant from Cape Town four hundred and twenty-five miles. Capes Padron and Recife are the promontories by which it is bounded. The settlement belongs to, and is under the control of the Government at the Cape of Good Hope. The entire district, as far as Port Natal, some distance North of Algoa Bay, is known generally as the Cape Colony.

Algoa Bay is rather an open roadstead than a safe harbor. Vessels lie at from one to two miles from the shore, with which they communicate by means of surf-boats. Upon entering the roads, the captain chooses a berth for his vessel, and there brings her to, with two anchors. One hundred fathoms of cable are paid out on each anchor. The swell of the Ocean beats in here with the wind at the South-east, and makes rough riding. It is at all times necessary to keep an anchor watch. 
A South-easter almost always sends sc me ressels ashore. The beach, which rises gradually from the bottom, is composed of sand. When a ressel once begins to drag, there is but little hope for lier. She goes ashore, taking with her all who come athwart her hawse while drifting. Vessels are generally, in such cases, washed high and dry. There is but little danger to life, and sometimes the crew get off without even wetting their feet.

Our first operation, after anchoring, was to send down topgallant and royal yards, and house topgallantmasts. Larger vessels, which were to wait some months for cargo, had their topmasts housed, and topsail yards on deck. But as we were to remain but a very few days, our preparations were not so extensive.

This sending down top-hamper very much lightens the strain upon the anchors, as of course the wind, which in a gale bears with it a very tangible pressure, meets less resistance aloft. It is a practice very common in the Indies, where harbors are poorly sheltered, anchorage is unsafe, and periodical hurricanes sweep with almost resistless force across the surface of the sea.

Our only communication with the shore was by means of surf-boats. These are large, roomy boats, sharp at both ends, and capable of bearing from three to six tons each, of freight. They aro nisnned by a people there called Malays, and by Africaners. The former, from their appearance, [ judged to be descendants of Malay settlers. 
They had the bright yellow color, the high cheek bones, and lithe figures of the native Malaccan. The Africaners were fine looking men, with long wavy hair, and sharp features.

The boats are hauled to and from shore by means of large coir hawsers, stretched along over the bottom of the bay, from the landing to the anchorage. We were scarcely at anchor when a surf-boat was seen putting out toward us, overhauling and carrying along a hawser which had before lain at the bottom, and which they guessed would be found, at its outer end, to be moored bui a little distance from our vessel. They were mis. taken, however. But the moorings of these lines are buoyed; and a few minutes after they got out to us sufficed to pick up a line which was suited tc our place. This was immediately made fast to our bows, by the bight, to use a sailor-phrase, the end remaining fast to its moorings at the bottom. This completed, the captain jumped into the surfboat, and was taken ashore. We now learned for the first time, that as this was the South-easter reason in Algoa Bay, no one but the captain was allowed to go ashore. This was a sad disappointment to me, again, as I had set my heart upon an exploration of the place-and would not have hesitated to accompany some old Cape farmer into the backwrods of Africa. But the fates ordained otherwise.

These Cape "Boors," as they are called, seem to be a queer set. With a good spy-glass we could 
see their huge, clumsy wagons, dragged by oxen almost innumerable, approaching the town, over a high ridge at its back. They brought in wool, ostrich feathers, lion's skins, beef, butter, and many other articles, which form the export trade of the port. Long, slow-moving trains they were, looking to us like vast serpents crawling along.

So we were not to go ashore. This vexed my ill satisfied shipmates, who would have been glad enough to desert here, had there been the slightest opportunity. Not that they had not been in worse vessels. Not that the voyage was unbearably long. Not that the labor during our stay in port was likely to be exhausting. But simply because they had by this time found out all about the vessel and her officers. They had exhausted the excitement of novelty on board, and their restless spirits pined for more. It is so always, atsea. I was possessed with this spirit, as well as my shipmates. And to me, as to them, it was a bane to true contentment.

It was on the third day after our arrival in the roads, that a regular South Easter blew up. The air, at no time since our arrival too genial, became almost frosty. Heavy storm clouds blew in dense white masses to the North West. The sea began to roll in, in mountain surges, threatening to engulf the vessels which lay anchored in its course. The surf boomed solemnly from shore, and the wind shrieked through our rigging, until one could scarcely make himself heard on deck. 
Our brig was furnished with new ground tackle and patent anchors. We were tolerably secure also, in the berth our captain-an old visitor here -had chosen. But as the little craft tugged at her anchors, head to the swell which tossed her about as though but a feather's weight; every few minutes a sea would board her over the bows and sweep spare cable, buckets, men, and every thing movable, aft. We were obliged to batten down the hatches and to close the forecastle and companion hatches with the utmost care, to prevent some chance wave from swamping us.

The breeze freshened toward evening, and the mate, examining his barometer, foretold a hard gale before midnight.

"Mr. McDonald thinks the Earl of Harwood will drag before two hours," said the cook, as he gave us our tea.

"Let her drag," answered Scotch Jack,"she wont fall foul of us. And that will be another Scotch vessel gone to the dogs. I wish they were all at the bottom, and their masters with them."

Scotch Jack could not bear those of his countrymen who chiefly command vessels from the Mauritius. He was from Glasgow. Our captain and mate, in common with most of their countrymen in this part of India, owned Aberdeen (they pronounced it $\boldsymbol{A}$-bur-din) or its immediate neighborhood, as their home. Between these two sections of country there has long been much jealousy. Sailors from the western cnast of Scotland can 
B:areely ever be gotten to do justice to those on the East Coast-whom they think sneaks and mean fellows generally.

At eight o'clock when the anclior watch was set tor the night, we dropped a third anchor unde: foot, and paid out some more cable on the others. The wind was now directly on shore, and the long line of white surf which stretched from beam to beam showed plainly the vessel's fate that dragged her anchor this night.

We had set the Earl of Harwood by the compass, and those on deck now kept an eager look out upon her to see if she changed her position at all, as that would be a sure indication that her anchors had broke ground. The fate of two other vessels, one of them partly owned by our captain, depended, in a measure, upon this vessel's. She was anchored directly to windward of them; and If she got adrift, they would be either cut down and sunk, or to prevent such a catastrophe, would be forced to slip their cables and drift ashore.

Meantime, the gale roared through the rigging with freshened ixpetus, and the surf boomed on the beach with a noise like many thunders. My watch on deck was from 10 to 12 . As my watchmate and I came on deck, the Earl of Harwood began to drag. At first she lost ground but slowly. Her people were paying out cable, in hopes to get their anchors fast once more. Tho rffeers of the brig and barque to leeward, were 
violently gesticulating to the Earl of Harwood' crew, as we could see through a night glass. They evidently desired these to cut away their ressel's masts, as the last hope of saving her and them selves. But this they would not do.

"I'd sooner try to beat the old craft out, at the risk of burying her bones in the sand, than to cut away those masts; we would never get a set like them again," the Earl of Harwood's mate had said on the previous day, while talking to our mate.

But beating out was an impossibility. Only a year before we were there, a mail steamer, dragging in a south-easter, had attempted to get clear by means of sails and steam; but after a desperate struggle of some hours, had gone ashore. How, then, could one expect a vessel depending altogether upon sails, to be cleared?

"That time she dragged at least a hundred fathom. Another slip like that will bring her foul of the Margaret," said the mate, who was closely watching every turn in affairs. "If he would slip now, hoist his jib, and run her ashore, he would do no damage to any one else."

"There goes the jib!" shouted the cook, who had turned out to witness the exciting scene.

"Yes, there it goes," said Scotch Jack, as the sail blew out of the bolt ropes, torn to shreds by the fierce gale.

"That's a mishap, now, for the poor Margaret." The Harwood's crew had slipped their cable at 
the moment of hoisting the jib. 'The sail gone, they were now helpless, and dr fted with lightning speed down upon the Margaret.

A few minutes decided her fate. Half a ship's ler.gth ahead would have cleared the Earl of Har. wood. But that half ship's length could not be got. In less time than it takes to read the account, the two vessels were hopelessly fouled. There was a sharp crash heard above the gale, and in the next moment the Margaret, jib boom and foremast hanging over the side, was drifting toward the surf, with the Harwood. The barque was untouched. Fortunately for her, the Harwood's jib and the opposing forces of the collision gave the vessels another direction.

In less than ten minutes after the Margaret got adrift, both vessels were bilged, ashore. It was a clear, moonlight night. We could see them, as they were tossed about like two chips, in the mountain surf. The Harwood came down, head on, the foresail being set for a moment, as she got into the surf, to give her a proper direction. The Margaret had lost all her forward spars, and was obliged to drift on helplessly, broadside to.

One high toss on the surf, and the two vessels struck. Then for a few minutes the hulls were concealed by the surf which broke furiously over them. But each wave washed them higher up: and in twenty minutes after they struck, both hulls were lying mastless, on their bilge, almost beyond reach of a common swell. 
"The Margaret's crew will get ashore without difficulty," said the mate, who had been examinlng with his nightglass the situation of the vessels. "But the Harwood has fallen over with her decks toward the surf. It will not be such an easy matter to get ashore from her."

In truth, we were told two days after, when the gale subsided and we once more held communications with the shore, that some of the Harwood's crew had narrow escapes, the surf beating so violently against the vessel's exposed deck as to make their position for a few minutes exceedingly critical. The Margaret's people saved all their elothes and other valuables, and had she had any cargo on board, would have been able to have saved that also.

In Algoa Bay, as in every other seaport in the known world; there is found a Lloyd's agent-a person who acts on behalf of the Marine Insurance Companies. I have often wondered how it comes about that whenever there is a wreck, one of these agents appears almost simultaneously with it. Let misfortune overtake a vessel in the most unfrequented spot in the globe, and I am sure a Lloyd's agent would be on hand. Like the stormy petrel, he is seen principally during a gale and after its subsidence. In fine weather he relapses into insignificance, and be he independent merchant or commercial agent, has no marks to distinguish him from others of that class. Wo might have wandered over Algoa Bay for a week 
and never had cause to suspect the existence of a Lloyd's agent in the place. But no sooner did it become evident that some vessels must be wrecked, than this worthy appeared on the beach, surrounded by a posse of natives, bearing tackles, rollers, boats, and divers other contrivances to facilitate the safe landing of the crews. And scarce was the Margaret abandoned by the crew, than this master spirit of the storm was seen climbing up her side, intent to seal up everything movable, and guard the vessel and all within her from marauding hands. While she was lying at anchor in the Bay, he had no business with her. No sooner was she wrecked, than she was so entirely under his charge, that her own captain, wanting some sail-twine which was left on board, was obliged on the following day to purcbase it of the agent. 


\section{CHAPTER XVII}

JONSEQUENOES of the wreck-A new crew-Scotch-English-Uson of a barometer-A South-easter Squall-Return to Port Louis-Ship for England-The Pauline Houghton-Talking to the Mate-Our crew-Paddy-An examination in Seaman. ship-The ship-Her rotten rigging-The captain's daily Siesta-The mate gets himself into trouble-How to gain the respect of a tyrant-Shooting at a mark-The TradesPaddy's last torture-Short handed-Sufferings-Recuperating-Seeking a berth-The last act of tyranny-Paying offA "Recommendation."

As BEFORE mentioned, our captain was part wwner of the Margaret, which vessel was now wrecked. Among her crew were four apprentices, Scotch boys, belonging to Peterhead, where the Annie was built. These boys, being now without a vessel, but still having claims to wages and employment, Captain McDonald determined to take on board the Annie, discharging four seamen to make room for them.

Accordingly, on the second morning after the gale, the skipper came on board. He called us aft, and asked who of us desired to leave the vessel here. Every one at once expressed this desire. Scotch Jack, in his dry, bantering way, which irritated the skipper exceedingly, said that ho 
dearly loved the vessel, and her officers, and would not leave on any account, but for the fact that he had a wife and family at Cape Town, who, ho feares?, needed his protection.

"You impudent varlet, I've a mind to keep you, as punishment for your sauce," said the skipper.

"Do so, if y iu please," answered Jack ; "I don't like to stay longer from my family, but you have such an agreeable way with you that I could easily find it in my heart to make the sacrifice."

This allusion to the captain's "agreeable way" capped the climax. Foaming at the mouth, he advanced toward Jack, who stood, meekly smiling; before him. He dared not strike him. A single blow would have been the signal for a general melee, in which, although the crew would have doubtless suffered for it afterward, he knew he would fare very roughly.

So the worthy man contented himself with applying to Jack all manner of opprobrious epithets, calling him a lazy scoundrel, a mutinous rascal, and declaring that he was not deserving of so good a craft as the Annie, and could not appre ciate the generous treatment he had received. All this Jack bore with imperturbable gravity.

But when the skipper, stung possibly by his coolness, ventured to call him " no sailor," Jack, fire flashing from his eyes, stepped $\mathrm{r} p$ to him and said, "You wretched North-coun'rymar - you talk of sailorship. There never was a sailor in all your miserable place. There is not in a million 
of you enough soul to make one seaman. You are fit for nothing but to tyrannize over better men than yourself: you and your booby brother. You remember Glencoe. I wish your whole infernal clan had been killed there, that there might havs been none of the ugly brood left."

This last remark was in allusion to the fumed massacre of Glencoe, where almost the entire clan of McDonald was destroyed.

The skipper cowered under Jack's glance, and contented himself by ordering us all forward.

We now fully expected to have "leave' to retire," as Jack called it. In the course of the forenoon, however, the cook whispered to us that only four were to be discharged. Who is the unfortunate, fated to stay? was a question asked with some misgivings by each. Even Jack was troubled by the fear that the captain would retain him, and on the passage home pay him up for his saucy language.

"If he does, as sure as I'm a living man, he'll never leave Port Louis again with whole bones," vowed he.

At twelve o'clock the mate announced that "Yankee Charley," the present writer, was to remain on board. The others were ordered to prepare for going on shore by the first boat in the afternoon.

"I would rather it was you than me, my poor fellow," said Tack, with a pitying smile.

I proceeded straightway to the captain, and 
requested permission to accompany the others $\mathbf{A}$ gruff "No" was the answer; followed after a moment's consideration on his part, by a more civil sefusal, in which he stated to me the reason $\mathrm{fcr}$ which he desired to discharge the others. At the same time, he declared himself satisfied with the conduct of all but "Scotch Jack," and ventured upon the opinion, that but for him we would all have enjoyed the outward passage much more than we did.

It was not without some sinking of the heart that I saw my shipmates take a joyful leave of the Annie. They had no pay to take, and had but seven shillings (not quite two dollars), among the four. Nevertheless they were as jovial as though their pockets were lined with rupees.

"Give my regards to the consignee and his family, in Port Louis, Captain McDonald," were Jack's last words, as the surf-boat shoved off.

The returning boat brought on board four greenlooking Scotch boys, ranging from fourteen to twenty years of age. They looked at me with evident suspicion, and sat apart in the forecastle at supper, devouring their tea and biscuit without any attempt at establishing a friendship. For this I cared but little, as their acquaintance was little desirable. But their language was a sore thing to ears like mine, unaccustomed to hear the King's English treated disrespectfully. For a while I listened, in the vain hope of understanding somewhat of the jargon which they called 
English. Vain hope, truly. It was worse thas the French upon which I had months ago ex. hausted all my powers of understanding.

But the worst was yet to come. On the morning following the advent of our new crew, the mate came out ten times more Scotch than ever; and when, not understanding an order he gave, I asked him to explain himself in English, he gravely asked if that was not English, meaning the patois in which he had spoken. The majority rules, even on shipboard. While our old crew was yet on board, the plain "Anglo-Saxon" carried the day triumphantly, and more than once Scotch Jack took occasion to rally the officers upon their unintelligible Scotch English, by asking them if such a language was permitted beneath the British Union-Jack. But now the other side was in the majority, and-it shortly began to be whispered about among the boys, that I could not understand plain English.

This was good enough to laugh at. But when some days after we left port, the captain in a fit of unusual candor owned that he did not under. stand more than half I said, the rnatter assumed to me a graver air, and I heartily advised him to procure a grammar and dictionary of the English language.

Our return cargo for Port Louis consisted of salt, sheep, and butter. In one week after our change of crews we were loaded. We got under way with a fine but rather stiff North-wester-a 
wind that blows right out of the hartor. The lop-gallant masts and top-gallant and royal yards had been sent aloft the day before. One anchor was on the bow.

Before we broke ground on the other, the foretopsail was set. On heaving "short stay a-peak" the anchor broke ground, and before we could run it up to the bows, had caught a fair half of all the surf-boat lines in the bay. In vain we tugged at the windlass. In vain we lowered and backed the topsail. In vain we payed out chain. The lines were fast about the anchor flukes, and remained there. Finally, after wasting an hour in fruitless efforts to clear ourselves, the skipper ordered all sail to be set that she would carry; this done, wo bore gallantly seaward, with an anchor and fifteen futhoms of chain overboard.

When we were two miles from land the vesse] was hove to, while we hove up, eatted, and fished the anchor. Three hours were consumed in clearing and coiling down the stiff coir lines and hawsers with which the anchor was encumbered. Some of them were from thirty to fifty fathome long. I dare say the surf-boatmen did not spare their maledictions at our carelessness.

The passage to Port Louis was sufficiently uneventful. I learned somewhat of Scotch clannish. ness, and a good deal of Scotch brogue. I learned, that to speer meant to look-that a dibble was a spoon-that in short, Scotch and English were two different languages. And I arrived, probably, 
at a better understanding of Burns's delightful songs and poems, than I would else ever have attained.

It was on this voyage that I saw illustrated to better advantage than ever before, the uses of a barometer. Our captain owned a most excellent one, and by long study had made himself a scientific observer of its mercurial motions. I have before stated, that to watch the compass was his greatest delight. Next in importance to this was the barometer. When on deck, particularly on this homeward passage, be vibrated regularly between the binnacle and the barometer. When at dinner, he would look up to see how she headed, and then rise to glance at the barometer. In the night, if his eyes opened to look at the compass overhead, his mouth at the same time opened to shout "how's the barometer, Jims?"

I must own that much trouble was saved us hy his close watch of this weather gauge. The African coast is squally. The squalls do not rise gradually and perceptibly, as in other latitudes, but burst suddenly upon a vessel, giving no pre. vious warning to the most watchful mariner. But by the aid of our faithful barometer the approach of one of these unwelcome visitors could be foretold some hours.

Thus, we would be going along with studdingsauls set, under a press of canvas, and with a good and fair breeze; no sign in the heavens would indicate a change. While congratulating 
ourselves, perhaps, on the steadiness of the wind, and the fine progress we were making, the skippor would order the studdingsails taken in.

"Is the poor man daft?" said Scotch Jack, the first time this maneuver was performed. The studdingsails in, the lighter sails would be clewed up and furled. The topsail halyards were then laid down, tacks and sheets were cleared, ready for running, and all was again expectation. Often an hour would elapse before the squall broke upon us. On these occasions there were not wanting weather-wise tars who thought our Scotch skipper "o'er careful." But the event always justified his prudence, and before we got to Algoa Bay, we, the forward hands, acknowledged that the captain and his weather glass were more skillful judges of the weather than the oldest tars.

On the passage to Port Louis I, for the first time, met one of the South-easter squalls, peculiar to this African coast. We had got the wind from the South-south-east, and were going along merrily before it, with all sail set. The weather was balmy, the sky was filled with white clouds, but no symptoms were there of an approaching squall. Toward noon the air grew chilly. At two o'clock I, who had muved about decks all the morning in my shirt sleeves and barefooted, shivored at the wheel, though wrapped in a stout peajacket. The breeze was all this time gradually freshening, and the huge, snowy-white clouds rolled up swiftly from he South-east, and covered 
the heavens, leaving scarcely a spot of the blue sky perceptible.

At half past two the royals and top gallant studdingsails were taken in. Shortly thereafter, a heavy white cloud appeared above the horizon. As it developed itself, a small black spot appeared in its center. This would not have been noticed by an inattentive observer. Yet this contained the squall. As the cloud approached, the black diffused itself over the white.

"Stand by your top-gallant halyards," said the skipper.

Now a few drops of mixed hail and rain-the advance guards of the squall-fall upon deck. And now the wind changes about two pointsthat is, to due South-east.

"Keep her off before it," says the captain.

The sails flutter a little; and then, with a heavy shower of hail, the ice-cold gust strikes us. One strong sweep of the wind, which lasts not minute in all, and all is over. The hail turns to rain. This ceases. The sun shines out brightly. The clouds disappear. The wind comes back to South-south-east. The sky resumes its clear blue; und the air is again balmy as before.

The blast was as though some huge giant ha! blown a breath against us. One almost deafening roar, and all was past. It was a singular phe nomenon.

We arrived at Port Louis in eighteen days from Algoa Bay. Going on shore, I took pussession 
once more of the room which I had occupied previous to my departure in the Annie. Here I found installed, on my return, a British sailor with whom I had once made a voyage from Canton to the Isle of France. We were very happy to meet. He told me ships were exceedingly scarce. It was now the hurricane season, when the harbor of Port Louis is not thought safe for shipping. At this time of the year therefore, business is especially dull.

"What do you say to shipping for England?" said Fred to me one day, shortly after my arrival.

"We can never make sufficient here for a start; whereas if we go to London and thence to New York, we can save as much off a couple of voyages in one of your Yankee ships, as will give us a nice start out here."

This idea pleased me. We talked the matter over a little more at length, and finally determined to ship as soon as possible for London.

On the morning following the final settlement of our plan, we walked down upon the mole, to place ourselves in the way of ship captains who should come ashore in search of men. After walking about awhile, enjoying the cool shade of a huge banian tree which half covers the mole and jetty, we proceeded up town. On the way ap, we were hailed by a short, stout man, who asked us if we did not want a ship.

"Where for?" inquired Fred.

"For London." 
"What's her name?"

"The Pauline Houghton."

"That's one of Blythe's yellow abominations," waid Fred, who prided himself on his plainness. "She belongs to the Messrs. Blythe, my man, and is a good ship," was the captain's answer; for the individual who had stopped us was her captain. "And what may your name be, Sir?" asked Fred, more respectfully.

"Captain Joseph Smith."

"Why," exclaimed my shipmate, with an oath which I shall not set down here, "You're the fellow that so misused your crew on your outward passage, that they preferred thirty days in jail and the loss of their hard-earned wages, to going home with you. And now you ask good men to go with you?"

"My crew were a set of skulks and worthless fellows. Good men need not fear ill treatment from me. The wages are two pounds ten, and a month's advance. Won't you go?"

"We'll think about it," said Fred, as he took my arm, and walked off.

"Now Charley," continued he, "I'm not afiaid to go with that fellow, although doubtless he is an outrageous rascal. I know one of the crew that is now in jail. He told me that the mate used to beat some of the men over the head and shoulders with handspikes, when they did not steer to suit him. And they say, too, that 'infernal scoundrel is the best word which issues from him," 
"But then," said I, "a man is foolish to permit " other to eithor curse or abuse him."

"That's just my opinion. And I have an i lisat we can make a homeward passage with $t$ fellow, without a hard word passing belween u I can do my duty, and I've seen you do yours, ny boy-though you are a Yankee"-added he crabbedly. "So let's go dowr and talk to captain Joseph Smith.":

We iminediately walked down toward the Pallline Hougbton's consignee's house. 'There meeting our crptain, Fred, with a degree of candor which must have been vastly annoying to that worthy, proceeded to tell him that we had heard from his last crew that he and his mate were a pair of great scoundrels, and that his old tub (meaning the Pauline H.) was scarcely seaworthy; but that as he wanted hands, and we desired strongly to go to London, we had concluded to go with him.

"This lad," continued Fred, pointing to me, "has sailed in the worst craft out of Port Louis, and acquitted himself respectably. As for meif you or your mate can teach me any part of my Juty, I'll give you leave to handspike me three times a day. But we have neither of us been useri to cursing or blows. And I give you fair warnmg that we shall return both with interest. Civi] reatment will get a power of work out of us. But wlen a man treats me uncivilly, he makes sothing."

This sounded to me a great deal like bravado. 
But 1 suppose it was necessary under the ciscum. stances. However unpleasantly Fred's harangue may have affected the captain, he restrained his wrath, and smilingly invited us into the store, to sign the articles.

This done, we promised to be at the landing stairs by three o'clock thal afternoon, with ous effects. The rest of his new srew were already on board. The vessel was to ..si on the following day.

By half-past three, we were alongside the Pauline Houghton.

"Where to, now, Charley?" hailed an old ship mate from a country vessel's bows, as in company with our new captain we were being pulled on board.

"To London."

"What! in that dirt-colored hulk in the outer tier? Well, you have been and gone and done it, my poor fellow. Don't you stand any of that fellow's nonsense. If you thrash him once, he'll be good as pie to you afterward," and my jolly friend tipped our savage-looking skipper a wink. Fred smiled grimly at the banter, while $I$ judged it best to say nothing in answer.

A volley of oaths from the mate, directed atsome man who was trying to cross a top-gallant yard, saluted our ears as soon as we got within hearing of our new vessel.

We looked inquiringly at the skipper, who said, "I'll stop that as soon as we get alongside." 
We had just got our chests secured in the forecastle and were looking about the forward deck a little, when the mate hailed us with, "Now, then, d--n your eyes! get aloft there, and help cross that topgallant yard. We'll have no loafers on board this ship."

"Come aft with me, Charley," said Fred, quietly. We walked together up to the mate.

"This young man and I shipped here to do seamen's duty, Mr. Mate, whatever your name is," said Fred, coolly; "we don't want abuse. We are going in this vessel to London; and I want to give you warning, that if you ever curse at either of us again, while we are in your ugly tub, you'll have us both in your hair. We can do our duty with. out that."

'The mate looked from one to the other of us, in speechless surprise, for a few.moments; ther uttered in a low tone an ejaculation to the effect that he "hoped to be" quite the reverse of saved, "if that was not cool;" then scrutinized our countenances a little more closely, and finally spoke up in a quiet, gentlemanly manner,

"Well, men, go aloft and cross that foretopgallant yard. Send those men down who are up there. I'll send you up the sail as soon as you aro crossed."

We had gained the victory. From that day to the end of a long passage of one hundred and thirty-five days, no matter how provoking was the wind, weather, or vessel, neither captain or 
mate ever treated us in any but the most gentla manly way.

"That comes of speaking up like men with ouls, my lad," said Fred, as we jumped aloft to do the mate's bidding.

We sailed on the following morning. I have before stated that in Port Louis, ressels are moored with four anchors, two ahead and two astern. As it would be exceedingly inconvenient to weigh these anchors by the ship's capstan or windlass, mooring boats are supplied by the harbor master. Each of these boats has a diver among the crew. This man takes a stout rope in his mouth, and dives to the bottom. Here finding an anchor, he puts the rope through its ring, and brings up the end with him. By this the anchor is hove to the water's edge, when it is taken alongside of the vessel, and stowed away.

These divers have great skill in their vocation. A few days before we sailed, the captain of a vessel had lost overboard a gold watch and chain. His vessei iay in twenty fathoms water (one hundred and twenty feet). A diver, hearing of the mishap, iffered his services to recover the lost property. The place whence it dropped was pointed out to him, as nearly as possible. He dove to the bottom, and almost immediately brought up the watch and chain. Ten rupees (firo dollars) was all he asked for this service.

Well, we sailed. Our crew conisted of eight men. The vessel should have carried ten; but 
the ill repute in which she stuod among seamen in Port Louis, made it impussible to procure more.

Had these eight been able seamen, we would Lave gotten along tolerably well. But two of them were runaway soldiers; one was an Irish man-of-war's man, who had served three years in the receiving-ship at Portsmouth, in England, in the capacity of ship's tailor, and had afterward somehow strayed out to the Isle of France; and another was a deserter from some outward-bound American whaleship. None of these four could steer our heavily-laden vessel, so that the entire labor of steering, except in very fine weather, fell upon the other four of us-no slight addition to duties already sufficiently onerous.

Our runaway soldiers were the best of the greenies. Rejoicing in their new liberty, they were ready and willing to do all they could, and quickly learned all the minor and less important duties of seamen.

The whaleman was sick nearly the entire pas. sage. He was paying a fearful penalty for past excesses. Aside from his illness, he was a spiritless creature, who permitted the officers to treat him as they chose-which was in a most rascally way, to be sure.

But our Paddy was a genius. He had been told that "there is no such word as can't, at sea." Accordingly, he took especial care never to utter this forbidden monosyllable. 
"Paddy, can you steer?" asked the mate of him. on the day we sailed.

"Yes, sir," was Paddy's ready reply.

No more questions were asked. But when the decks were cleared up, and the watches chosen 'Send the gentleman from Ireland to the wheel!' sung out the captain.

Accordingly, he took the wheel, and in less than owo minutes had the vessel all in the wind, sails shivering, sheets slatting, and the spanker boom nearly knocking him overboard.

"I thought you could steer!" shrieked the skıpper, in a rage, at the same time applying a rope's end freely to Paddy's shoulders.

"I thought so, too," submissively answered the Irishman.

"Do you know the compass, at all?" he was asked, after we had once more got the ship upon her course.

"Yes, sir."

"What's this point, then?"

"That's North."

"Right. Now what is this next to it?"

To this there was no answer. Paddy had mado m his mind not to confess ignorance of anything. And when he knew nothing, he wisely held his sorgue.

After giving him a hearty cursing, the captain sent him forward. Here he received from the sailors another series of curses, for shipping under false pretences $\mathrm{He}$ bore it all in dogged silenco. 
That r: ght, the second mate, in whose watch he was, told him to slack up the foretopgallant clewline, which happened to be too tight. He went forward, and let go the foretopsail halyards, car. rying away by this stupid trick, both foretopgal. lant sheets. We of the watch below were awak. ened by his cries to the second mate for mercy. We lost two hours' sleep by his blunder, and did not therefore feel sorry that he got a beating, severe as it was. He bore the marks of it upon him for nearly a month.

We were a week from land ere we arrived at' a full understanding of all the length, breadth and depth of his ignorance. He actually knew no more about a ship, than a person who had never seen one. When sent aloft to furl the royal, he whispered to one standing near the main rigging, "Is it the highest one?"

On receiving an affirmative answer, (accompanied, I must say, with a curse,) he hurried aloft. But now instead of rolling up the sail and passing the gasket lines about it, he sat on the yard and looked sapiently down upon deck.

Such a look of angry astonishment as filled the mate's face upon this occasion, I never saw equaled. "Why don't you furl the sail, you booby?" he shouted.

"Aye, aye, sir!" answered Paddy. readily onough, but never stirring.

"Roll it up, you infernal stupid! and come down here quick; I want to thrash you!" shouted tha 
skippor, dancing about the quarter deck with rage.

"Oh!", said Paddy, as though the whole idea had suddenly burst upon him. And then he began to roll up the royal. But as he was in evident ignorance of the existence of gaskets, when he got the middle rolled snugly he found sufficient to do to hold that, without attempting more. He cast another despairing look upon deck.

One of us was now dispatched aloft to help and show him how to take in a sail. But Paddy, look on as carefully as he would, could never be taught to perform this operation.

He did not know a single rope, and indeed, all our efforts to teach him to the contrary notwithstanding, was no wiser in this regard when he left the barque in London, than when he came on board, in Port Louis. Seeing the poor, foolish fellow so much abused, I took pity on him, and in the moonlight night watches used to go around the ship with him, to tell him the names and uses of the various ropes.

Thus, I would say, "Now, Paddy, this is the forebrace-this is the foretopsail brace-this the foretopgallant brace-and this the foreroyal brace;" making him touch each o le in successior, and repeat its name over after mo.

"This is the maintopsail clewline, and this the buntline-these two the maintopgallant clewline and buntline. Now," touching the forebrace, "what rope is this?" 
"Be Jabers, Misther Charley," he would rep!l, after an awkward pause, "is it a clewline?"

Night after night, I worried myself and him, to teach him at least a few of the most important ropes. But all to no use. To the last, he used to go to the maintopsail clewline when the forebrace was to be pulled upon. And on the very last day of our voyage, as we were being towed up the Thames, Paddy, told to slack up the spanker vang, let run the peak halyards, nearly killing himself by the operation. But he never uttered the word can't. This had been drilled into him.

Such extreme ignorance was almost incredible to seamen. We took upon us to cross questior him as to his outward voyage-from London to Port Louis.

"How did you get along there, Paddy? Did not they beat you occasionally?"

But Paddy preserved a judicious silence upon this part of his history.

Had not the officers beaten him so much, he would have fared hardly in the forecastle. But the daily-sometimes almost hourly-ropes-endings he received at the captain's hands forced us to take pity upon him.

Some others of our crew were not much better treated than Paddy. In fact our officers had a strong inclination to ill use any one that would, stand abuse, and it was only by a continual show of independence, and a readiness to resist all 
attempts at special tyranny, that four of us-in cluding Fred and myself-were able to retain a peaceful and comparatively comfortable positicn an board.

Although the mate had, after Fred's "personal expiaration" on our arrival on board, shown no farther inclination to use his billingsgate upon us, he had clearly' borne us in mind. Fred had boasted of his sailorship-and unluckily, of mine too. During the first ten days out from port the mate made us earn the reputation Fred had given to ourselves. From one piece of rigging work to another, we were jointly and separately sent over the entire ship. To-day a brace to splice-a very neat piece of work on board an Indiaman, as it requires that two ropes-ends be joined together in such manner as that the points of junction shall be scarcely discernible. To-morrow a hawser to crown, and the next day some other more complicated rigging to be fitted.

I must do the mate the justice to own, that he was himself an excellent seaman He knew much more about a vessel than officers generally-and was not at all backward in making known his knowledge.

"If he catches us tripping, Fred," said I, "we"I he in a bad box."

"If he catches us tripping, my lad, he'll have to know more about a ship than I could ever find out about ore." 
We passed the examination, and our not very good friend, the mate, was in consequence very kind to us ever after.

"And now," said he, one Monday morning, "bring aft your palms and needles, and I'll sct you to work on some sails."

All day he sat by us, watching us as we plied our needles on the soft canvas, and occasionally handing a more than usually difficult piece of work to one or other of us.

Fred smiled confidently; whereas I was annoyed, not knowing what moment some by me before unheard of "job" might be placed in my hands, by failing in which $\mathrm{I}$ should lose all the credit gained by ten days hard sailoring.

So it is in British ships. Let a man, be he never so ready and expert, but fail in one minute particular of seamanship, and he is counted "worse than a dog."

Toward evening the mate handed me a piece of bolt rope to splice in, where a part on the sail was defective. He stood by me while I performed the task.

"That's not the way to do that," said he sternly, after watching me for a while.

Fred looked up with some alarm. But it hap. poned that in this I was confident of being right. "That is the way it is done in American ships, sir."

"No matter; I want it done in ship shape None of your Yankee botch-work for me." 
"The Yankees don't as a general thing deal in botch-work," replied I. "I'll make the splice, and if you can draw it, or if it is clumsy, or af. to fall apart, I'll give up."

He waited patiently till I was done; then took my "job" and tried to pull it to pieces. Failin in this, as I knew he would, he declared himselfsomewhat grudgingly - to be content; and henceforth, with the exception of an occasional few hours work aloft, Fred and I were employed on the quarter-deck sewing -on sails; a much more pleasant task than swinging about on masts or yards, exposed to the broiling sun.

The barque was old. Her rigging was in a wretched condition; and after every gale all hands were busied for two or three days in repairing damages. Three times, in the course of our passage, a topsail came thundering down on the cap, with men upon it. Twice Fred and I were on the falling yard, having been sent aloft to make some repairs; and each time we had what landsmen would call a narrow escape. There was not on board sufficient rigging to reeve new halyards, and so the old had to be spliced-only to part again.

Once, when reefing, in a gale, the lift, a ropo which maintains the yard in its horizontal position, and on which the man at the earing dependa for support, gave way. I happened to be s.t tho earing. Had it not been for Fred's quick grasp of my hair, I should have dropped into the water. 
So entirely rotten was everything aloft, that no one felt it safe to perform the usual services to the sails. It was at the imminent risk of life that any one put his foot into the rigging. Neverthe. less, although each felt this, it was never alluded $10 \mathrm{ir}$ the forecastle. It would have been unsailor like to own to the possession of such a thought. And there was, among those of the crew who claimed to be seamen, as much readiness to go aloft, upon however irksome or really dangerous a duty, as though the rigging had been bran new from the rope-walk.

We were but a very short time on board before we became aware that our officers drank. The captain, more especially, took his bowl of grog regularly, after dinner, and from it relapsed into a stupid sleep, which he dignified with the name of siesta. Awaking from this, he would come upon deck and catechise poor Paddy on various points in seamanship; each failure in rendering a correct answer being attended by a blow from the rope next at hand.

On Sunday, if the day was fine-and most Sun. days at sea are pleasant days-the mate also took a siesta. After these occasions he would come apon deck, looking thunder at the crew. Wo to Paddy if he rame in his way then. There were crasions of this kind, when he could hardly force sumself to treat Fred or myself civilly. But there was something of warning in old Fred's eye, which probably told him that to attack either of 
us, winn Billingsgate or blows, would only get him into trouble. So we escaped.

Less fortunate were the rest. One Sabbath afternoon, while standing at the wheel, I heard a scuffle forward, and stepping to the side beheld the mate chasing a poor runaway soldier, one of our crew, with a handspike: Just then an athletics fellow, a seaman, who had been rather remiss in asserting his independence, came out of the forecastle. The mate immediately attacked him, ordering him, with threats, to go below. This roused George. He stepped to the windlass and sat down, saying, "I'm tired of staying below, and find it pleasanter on deck, just now."

"You hound," screamed the mate, white with drunken rage, "take that, and go below," hitting him a blow on the arm with a handspike.

George seized the handspike, and tossed it over the lee bow, saying, as he grasped the mate by the shoulders, and turned his face aft, "Now go inio your drunken eabin, blast you, or I'll put you where the handspike is."

A little struggle ensued, for the mate, though a bully, was not devoid of courage. But George held him as in a vice, and the mate writhed help. lessly in his grasp till he promised to go peace ably aft.

From this time George was also a favorite with the mate. In fact it seemed that to abuse him, or resist him, was the surest way to gain his respect and favo:. 
One quiet Sabbath afternoon, while just io the North of Ascension, the captain, waking up from his usual siesta, appeared on deck with two pistols. $I$ was at the wheel. It was a dead calm, ind the ship had scarcely a motion of any kind, so quiet $x$ as the sea.

"I need a little pistol practice," said the captain, as he loaded his weapons-two large bellmouthed instruments, holding an ounce ball each. After vainly looking along the smooth surface of the water, for some object at which to aim, he finally stepped to my side, standing about three feet from me, and aimed straight above his head.

"We'll see how nearly perpendicular I can fire. That will be a good way to practice."

His hand trembled as he fired, and presently we heard the ball drop into the water along side.

"That was a bad shot; I must do better than that."

The second ball dropped astern. The third went through the spanker, and so into the water astern again. A grin of satisfaction spread over his countenance, when he saw that he was improving. In the course of half an hour's firing the balls drcpped in the water in-all directions, possibly much surprising the fish with whom they came is contact in their course bottomward.

Finally, taking a particularly good aim, he fired, and the ball returned whizzing to the deck, makng a deep indentation just midway between the eaptain and myself. 
"I think we won't try that any more. Greatex perfection is not desirable," said he, as he gath. ered up his ammunition and retired to the cabin.

I will confess to being exceedingly rejoiced at his determination. It was by no means pleasant is stand still and be in this manner indirectly shot at.

Hard work, poor provisions (and a very small allowance at that), and two quarts of water per lay to drink and cook with, with officers that were brutes, and a vessel in the last stage of decay -all these things make a sailor's life the reverse of pleasant. And so we did not even enjoy as one ought the glorious region of the South-east Trades: those purer skies and brighter stars, bluer waves and softer breezes, which he who has once experienced will certainly never forget, nor ever think on without longing for their return.

On these followed the tedious and exhausting calms of the equator. Then, after weeks of idle drifting about at the mercy of every chance current and catspaw, came the re-invigorating Northeast Trades. And finally, the lowering heavens and gloomy sea of the English Channel. By this time we had only three men fit for duty. Even Paddy had at length succumbed to ill treatment, and now lay despairing in his berth, little caring for the diurnal threats of the captain, that ho would hoist him on deck with a tackle.

The last actual torture which this ponr fellow suffered, frightened him into a sickness. Having 
one day, during the captain's usual catechising, proved unusually stupid, that worthy, intent upon a novel excitement, determined to hang his victim cver the side on a level with the water's edge, and there make him scrub the long grass off the water-line. A stout rope was provided, and l'addy, who was a non-resistant, was made f:tst and helplessly lowered till he was up to the midcle immersed in water.

"Now scrub, you scoundrel," sard his tormentor, as in savage glee he looked down at him.

Paddy's entreaties for mercy were uninterrupted, save by an occasional sputtering cry, following upon his complete immersion. For as the vessel was under strong headway, she once in a while careened over sufficiently to entirely submerge the poor half-witted- Irishman.

There was no actual danger-the captain and mate having taken care to so secure him as to make it impossible that he should be lost overboard. But with Paddy's nervous condition, and constitutional antipathy to water in any shape except as "tay," he was in mortal fear.

After two hours of suspense, he was once more safely landed on deck. He took immediately to his berth, and did not recover from the shock of that morning till two or three days before we ontered the West India dock.

Channel navigation, hard at best, is a torture where it becomes necessary that three wretched men shall perform the duties for which an entire 
crew is not too powerful. Wearied, sore, chafed in every limb, till the blood flowed from our feer s we ran aloft, and from our hands as we tugged t sails or painfully dragged heavy chain-cables about the deck, we at length arrived in the Downs.

Here the pilot declared it necessary to procure a reinforcement of men from shore. And as the British Pilot makes his orders obeyed by captain as well as men, our labors were lightened by half $\downarrow$ dozen hands, who were engaged to assist in taking the vessel into her dock. Yet another day of hard labor, and with somiewhat joyful hearts we were gliding up the crooked Thames, behind a lowboat. The following morning we hauled the vessel into her dock and left her. This was on the one hundredth and thirty-sixth day since we sailed from Port Louis.

Going up to the "Sailor's Home," I deposited iny luggage, had a refreshing bath, trimmed my numerous sores, and at eleven o'clock retired to my bed, preferring sleep to the dinner which was ready an hour afterward.

My rest, undisturbed by many-dreams, was not broken till nine o'clock the following morning. These twenty-two hours of sleep restored in somo degree my usual elasticity, and after another immersion in cold water, and a hearty breakfast, I was almost myself again.

I had been in London before, and well knew that no time was to be lost in securing a vessel. There is nearly always, in that port a surplus of 
seamen; and mans a poor fellow has sur ugyled weeks for employment, nearly starving the while, before obtaining even a poor chance. I was determined to return to the United States, and leave British vessels henceforth to British tars. I therefore immediately proceeded to the St. Katherine's dock, where most American vessels are found, to inquire for a chance.

After asking for a berth in quite a number of ships and barques, I at last happened on a barque, some of whose hands had left her. She was not to sail for several weeks, so the mate said. Nevertheless, I resolved if possible to engage a place on her, rather waiting some time than losing the unance altogether. I accordingly sought out the captain. To my respectful request for employment, he gave a gruff reply, that he was daily, almost hourly, importuned by a parcel of lime-juicers.

"But I am an American," said I, thinking that with common perspicacity he might have seen this

"Yes, they all claim to be Americans. And when you once get them' to sea, you can't near $y$ urself speak for their growling."

"But can you not promise me a chance?" I asked.

"Do you want to wait three wecks?"

"If I have your promise to ship me, I will de s willingly."

"Well, you may wait, I guess."

"Can't you give me some kind of employment on board meantime ?" 
"No. I want no more idters than I'vo ge" now."

With this our interview closed. I told the mate, who seemed a more civil man than the captain, that the latter had promised to ship me.

"Come down every two or three days and show yourself to him, that he may not forget you," said he, kindly, in answer.

Meantime my last captain was making use of the last vestige of power in his hands, to make his crew uncomfortable. The British sailor is so important an individual to the prosperity of the Empire, and the British captain is so invariably a tyrant, that it has been found necessary - to hedge seamen about with numerous laws, by which it is supposed they are protected from the evil inclinations of their superiors. These in turn, having a line drawn over which they may not step, take care in general to go quite up to it.

Thus it is provided, for the protection of seamen, that they shall be paid off within ten days of the time when the vessel has been made fast in her dock. Accordingly, our captain told us to come to the owner's office on the afternoon of the ninth day, when our money would be ready for us.

It is usual, with the regular discharge, to give seamen in British vessels a "recommendation" to the tender mercies of any others who may propose to employ them. An American shipmaster or owner thinks a man's face and carriage sufficient to judge of his nerits. A Briton asks first for the 
recommendation, and it this is not forthecming, at once refuses, unless pressed for hands, to engage the applicant.

We had been told that our captain would refuse any one a recommendation. For my part I carcd little for it, as I was not to sail under the flag any more. My shipmates, however, felt somewhat anxious on the subject.

At the appointed time we met at the owner's offse. The captain was there. As each orie's name was called, he stepped forward to receive his wages and sign his account. Then the captain handed him his discharge-and recommendation, if any was forthcoming. Fred, Greorge and I, were the only ones of the crew who were favored with the latter document. I will here give a copy of mine, as it may satisfy the curiosity of some reader.

"This is to $\mathbb{C}$ ertify, That —- has served on board the Pauline Houghton, under my command, as able seaman, from Mauritius to London, and has conducted himself to my satsfaction; and can recommend him to any person that may require his services.

"Joseph R. Smith, Master."

With this precious indorsement in my hand. and seven pounds sterling (thirty-five dollars) the proceeds of my voyage, in my pocket, I left cap. tain Smith, thinking, "Take him for all in all, [I hope] I ne'er shall see his like again." 


\section{CHAPTER XVIII.}

I waIT for the Barque-Disappointed-" Working " a Passage-

New York after two years absence-Coasting-Cape Men-. Smyra, the Cook-Our Crew go Home-Ship Keeping-Sol. itude leads to Reflection-A Coaster's Life-A "Stranger"The Cape-The Mary Hawes_A "Fish Crew "-Fishing " at Half Line "-We Sail_-Preparing for Business_The VesselHer Captain.

AT the mate's suggestion, I came down to the barque every second or third day, and placed myself in the captain's way, sometimes speaking to him, at others, satisfied if he saw me. He occasionally expressed his opinion that I ought not to wait so long; yet never refused to ratify his prom. ise to ship me. Meantime, although entertaining no doubt as to his good faith, I kept a watch for nther chances, determining that if I could get $n$ berth in any vessel sailing earlier, I would accept it.

No such chance, however turned up. Every American ship that sailed was full manned, and in. many there were extra hands, who were working their passage. So I was compelled to await the expiration of three long weeks; during which time the sum $0^{\circ}$ money I had been paid off witb 
rom fine Pauline Houghton, was very considerably diminishal.

It wgs yet early in the year, and I knew that a passage across the Atlantic would notbe unattendod with cold weather. My first investment was therefore ir some warm clothing. This provided I felt more like trusting in Providence for thes balance.

A day ct me at length, when the barque was to ship hands. I presented myself on her quarter deck, early in the morning; where I was met by the captain, who told me gruffly that he found he should not need my services, as some other men had been shipped for him, by a friend. I looked up in his face in mute astonishment. It was too bad. I had depended upon his word so entirely, that the possibility of his failing to keep it had never entered my mind. Before I could make any reply to his announcement, he left the vessel.

Some of the crew, who from my frequent appearance on board had gotten to know me, shortly approached to question me as to whether I was shipped. On learning what the captain had said they at once explained the secret of this movement Some dealers in seamen's ready-made cloting, who had men on their hands, owing them money, had persuaded the worthy captain tc engage their men, they-the slop-dealers-retaining, of criurse, the advance pay they got. While the crew were talking to me, the mate came up.

"Are you shipped, my lad?" he asked. 
"No, sir; the captain says all his hunds arc already engaged, elsewhere.".

He appeared surprised. After a moment's silence, he asked, "Do you need any advance?"

"No, sir, I don't owe any one a cent."

"Would you work your passage, if the captain consents to take you?"

Now, to keep a man three weeks waiting for a place, and then ask him coolly to take the place and perform its duties, but without remuneration, I thought, looked a good deal like an imposition on good nature. Nevertheless, as my case was tolerably urgent, I expressed my willingness even to work my passage. Hereupon the mate sought out the captain, and after conferring with him for a fow minutes, returned to tell me that I might bring my luggage on board.

We sailed on the following day. To the surprise of all the crew, one of the other new hands claimed also to be working his passage. He had been entrapped into this in the same way by which I had been victimized. Here should now have been two extra hands. But there was just the regular number of us; so that by this operation, the saptain was enabled to pocket the wages of two men during the passage home.

This passage lasted forty days. We had some rough weather; but with a comfortable ship and tolerably kind officers, sailors care little for the weather. So we passed the time very contentedly; I daily wishing for a succession of fair winds, to 
shorten a passage for which I was to receive no pay.

It was cn a bright July morning that we entered Now York Bay. By four o'clock that afternoon, the barque was moored at one of the East River wharves; and I stepped ashore, after an absence of over two years from the United States, with three suits of seaman's clothing in my chest, and an English sixpence in my pocket, the result of those two years of hard work, exposure and deprivation.

I don't know but a glimpse of common sense penetrated for a moment the thick mist of romance with which I had always sought to surround the life I had chosen, as I stood upon the wharf, and remembered with what a light heart I had two years before sailed from that same pier to New Bedford; how I had willfully tempted fortune, by throwing myself recklessly into a life of which I knew nothing; how I had labored twelve months in all the filth, moral and physical, of a whaleship, and left her at last, with no returns to show for my work; how I had wasted more time in the Isle of France; and how now, looking báck, I could see two years of my life to all appearance thrown away.

"What would the folks at home think of me, could they see me now?" I asked myself.

"Don't you want your luggage taken up to boarding-house?" asked an express man.

"Yes, take me up to Cherry street, N נ. - ."

Arrived at the place designated. I stated my 
circumstances to the worthy man who there kept a boarding place for seamen. He knew me, and received me kindly, "money or no moncy," as ho expressed it. I told him that I wished to go off as soon as possible.

"Better stay a week or two to recruit yourself. Any money you want I will let you have freely You can repay it at your convenience."

I felt deeply grateful to him for the offer. Probably not another sailor boarding-house keeper in - New York, would have said as much to me. But I was determined to lose no time in idleness, and expressed a strong desire to go off cn the following day.

That evening the captain of a schooner trading between New York and Boston, came up to get a hand. I offered myself, was accepted, and engaged to render myself on board on the following morning, at six o'clock. So, having returned at four o'clock, r. M., from a two years' absence from the States, six o'clock the following morning found me working at the windlass-once more an "outward bounder."

Schooner sailing was somewhat strange to me. But the people, Cape Cod men all, were kind to we and bore with what must have seemed to them the rather gruff and odd ways of an old salt. Our srew consisted of five : captain, mate, two hands, and the cook. The latter was a little boy of ten years, the captain's son. All hands lived in the cabin, and the officers, although a little reserved 
in their conversation, as is the manner of Cape men, were kind-hearted, hard-working people.

They were plainly unused to the company of such an outlandisis fellow as I had by this time grown to be. Every article of my clothing seemed a curiosity to them. My old sea chest was an object of mysterious interest to the little cook, who evidently connected it in his mind with numberless romantic adventures. The shrewd little fellow lost no time in finding out my. weak side, and having once, as he judged, established himself in my good graces, straightway importuned me for a yarn; and I soon found that Smyra-that was his singular name-faithfully repeated my tough yarns to his father, who used to smile good-naturedly at his childish enthusiasm, and at my, to him, queer ways.

For myself, the company of the child was grateiul to my feelings. I liked his unsophisticated ways and ingenuous talk. And so I tried, and successfully, to win his regards. These little Cape boys start early into active life. Smyra had been cook since his eighth year, and now at ten, with all of the child about him yet, was as self-reliant and shrewd, in matters appertaining to his pecs. liar life, as many a young man at twenty-one.

Our crew had their homes in a little village $\mathbf{n} \mathbf{n}$ the Cape. It was the captain's custom to lay by here for a day or two, on each trip. Accordingly, when we were through the Vineyard Sound, our course was shaped toward Harwich, and by noow 
of the second day after we left New York, th. little craft was safely moored at "Deep Hole"the name of the particular anchorage chosen for her. We found here a number of schooners at anchor.

"What are those vessels, Smyra?" asked I, as we two were stowing the jib.

"Some coasters, and some fishermen."

With a quickness peculiar, I believe, to fishermen and coasters, the boy now beyan telling over the names of the various vessels. Many lay a mile off; but he knew them all. This was a coaster, that a fisherman; this a Harwood vessel, that one from Barnstable.

"And yonder in the offing is a Down-Easter."

"How do you know that? Have you seen her before?"

"No; but I know by her rig. No Cape man would have such a clumsy masthead to his vessel."

When the sails were furled, and all was made snug, our crew departed shoreward in the boat, leaving me alone on board, as "ship-keeper."

"There's plenty of eggs, and everything else you want, in the cabin, Charley; you must cook lots for yourself," said Smyra, as he gaily jumped into the stern sheets.

"And there are some good books in the cabin, too, Charles," said the skipper, "you can take whatevor you please."

So they went ashore to their pleasant homes, while I, poor fellow, remained on board in 
wlitude. It was a solitude I very much enjoyed. A Sabbath stillness reigned over the little bay in which we were anchored. Most of the vessels at anchor were entirely deserted; a few had a solitary ship-keeper, like myself a stranger to tho Cape. During the two days which our crews spent on shore I had ample time to take a cool review of the last few years of my life, and endeavor to plan out a future.

I was now in my twenty-first year. I had, unconsciously almost, grown to man's estate. And I was now fully awakening to the fact, that in the life I was leading there was nought to elevate, everything to debase a man-that day by day, I was losing ground, and lessening $\mathrm{my}$ chances of ever returning to a better life.

To a boy every change is welcome. He has the power to fit himself into any kind of life. The man is different; and I was alarmed when I found how much, in the last two years, I had grown into the peculiar ways of acting, and thinking even, of the genuine, irredeemable old sailor.

"A change must be made," thought I. "But how? Can I return home after years of unrequited hardships, and meet the pitying smiles of former friends, who have by more proper conduct distanced me in the race of life? No. This can never be. Will strangers give me employment on shore? Me, who bear in every line and motion tho evidence of being a sailor. "It appeared very unlikely. 
Nevertheless, I determined to try, as soon as 1 should have earned myself a little money, to support me in the attempt. How many months would elapse ere this should be accomplished, and whether for that long time my resolution would hold out, I could not tell. But this I determined henceforth to look forward to, as the aim of my life.

On the third morning our crew returned on board and we set sail for Boston. As we sailed past the Cape, we met numbers of fishing vessels returning to their port of discharge, laden with mackerel. Smyra, who had mado several trips "mackereling," was loud in his praise of fishing, and unceasing in his fish stories.

"Have you never been fishing?" said he. "You ought to go. It's great fun; and besides, I believo one can make more there than at coasting."

I paid little attention at first to his remarks; but his continued laudation of fishing life at last induced me to ask the captain if "mackerel catch . ing" was indeed a money-making business. Ho owned that in good seasons there was money made at it, but thought that steàdy wages were much preferable. I considered on the matter. Somehow, shortly, the old desire for novelty took possession of me, and I determined that after completing the return trip to New York, I would make trial of " mackereling."

Our voyage to Boston and back to New York was notable for naught but its plentiful lack of 
oxcitement. The coaster is the drudge among seamen. He shares all the severe toil, and much of the dauger incident to a sailor's life, without any particle of romance to redeem its commonplaceness. With him it is the same old story. New York, Boston, Philadelphia, Norfolk, or whatever may be his trading points, they present no strange scenes, no now life to his view. For a real prosaic, matter of fact, anti-poetic existence,'commend me to a coaster. One voyage was ever quite sufficient to last me a year.

So, by the time we reached New York again, I was quite ready to dive into some new phase of life, and gladly availed myself of the offer of a Cape captain to take me down home with him, and procure me a berth in a "mackerel catcher."

I sailed back to Harwich in a little schooner bound that way. On the vessel's arrival, I proceeded ashore, in company with the crew. By the kindness of one, I was introduced to a good widow lady, who consented to board me while on shore, and care somewhat for my effects while away. Thus a kind of home was provided for me, where at very little cost to myself, I could spend a few days after each cruise, in comfortable thougb rather solitary enjoyment. Solitary, because on the Cape a "stranger" is looked upon with some degree of distrust. The Cape people are tolerably clannish; and although universally kirid-hearted, never fail to remind a $₫ \mathrm{ew}$ comer that he is not one of them. In this, they are not indeed far 
wrong, for many of the strangers who temporarily sojourn in the fishing villages, and find employ. ment as mackerel and cod fishermen, are not too trustworthy; while most of them come only on the rather selfish errand of making a little money for themselves, to carry to some more congenial place than the Cape, to spend.

I remained a few days on shore, while the vessel in which I had secured a berth was being made ready for her first cruise. In these days, I saw sufficient of the Cape to convince me that it is not the most pleasant spot on the surface of our globe. The face of the country affords a not over agreeable diversity of views, consisting of sand. hills and salt water marshes, scrub oaks and stunted pines; the ground work and filing up of the picture being sand, the abundance of which amply entitles the country to the euphonious name of " the Great Desert of Cape Cod."

The shores of the harbors are masses of sand. Flats extend some distance into the water, making necessary the building of long, dreary-looking wharves. Even to these wharves the little fishing vessels can get only at high tide. Here they discharge sheir fish; and here, in the fish houses, they are sorted, inspected and branded, when they are ready for shipment, North, South, East and West.

The outlook seaward is scarcely more dreary than that from the sea landward. T'he stunted vegetation, the snug but lonely looking l*ttle houses, the great, barn-like structures called fish 
houses, each with the wooden image of a codfish or mackerel swinging from its steep rocf, the absence of grass or aught of green near the shores, and above all and mixed with all, the everlasting glare of the sand, all united to give the shores of the Cape a most desolate appearance.

Where a country is poor the people are generally thriving and-in their way-happy. So it is here. I don't know that a fisherman's life exactly fills my ideal of a happy existence. But the people are universally frugal, industrious and intelligent-their wants are few, their tastes the reverse of luxurious, and the labor of their hands suffices to make them a competence-so that after all, making due allowance for the many hardships of their peculiar life, they are very happy.

The widow lady with whom I had made my home on my arrival on shore, was kind enough to provide me with many little articles, necessary only on such a trip as I was about to make. She set apart for my use, during my stay on shore, a neat little room, in which-for the first time since starting to sea-I made myself perfectly at home Here I enjoyed once more, to some degree, a free. dom from exciting eare, which seldom falls to the sailor's lot. The quiet of the country-how mucb and often I had longed for it! - did my soul gord, and $I$ found myself in a condition of mind to sit down and reason with myself on the folly of the life which I had so long been leading. Here was atrengthened my previously formed determunation 
to leave the sea, and make myself a place "on shore"--that mystery to a sailor, whose visits to he land are just sufficiently long to make the hore life a marvel to him.

A little clipper schooner, the Mary Hawes, was just fitting out for a mackerel cruise. She had made two trips to "the banks" that year, had been successful in both, and her captain was now about to complete the year's work by a couple of months' mackereling. Captain Jonathan Young had the name of being a smart fisherman; a "very fishy man," as those who knew him best called him. He was bred to the business, and was supposed to know the haunts and motions of cod fish and mackerel as well as any one in that part of the country. It was a natural consequence that such a man should gather about him an able crew. Some of his men were not to be beaten; several had at different times been "high line" from Harwich; and all were good fishermen. I was fortunate in securing a berth in her, as I there enjoyed the ad. vantage of all their experience to enlighten my ignorance.

Fishermen do not of course labor at regular wages. The business is carried on on shares. The vessel has a certain share of the general catch. 'The captain has a share for his additiona] trouble and responsibility. An account is kept of provisions and fish-bait used, and this is forlly averaged among the crew. Each man kee Lis fish separate, and when they are "packed" (abu 
is to say, insperted and sorted), he receives either his net share of the fish, or their equivalent in money at the highest market price.

Sometimes, young men make a different arrange. ment, which is called "fishing for halves." They agree with some one ashore, generally a packer or inspector, to give him all their catch, he paying them in return one half its value, in cash, and taking the risk of making a clear profit from the balance. If the season is favcrable and the fisherman 'has good fortune, the shoresman 'makes money by this, while if the catch is small, he loses - the provisions and other incidental expenses averaging as high in one case as in the other.

Through the kindness of a friend, I was introduced to a gentleman who, in consideration that I was to go in the Mary Hawes, agreed to let me fish for him at "half-line." This arrangement gave me great satisfaction, as it reduced my chances more to a certainty; and I felt just then a strong desire to make them as certain as possible.

Fancy me then on board. Oiled clothes, a barvel (an oiled cloth apron), hooks and lines, a bait knife, fishing mittens, and divers other matters needed to make up a perfect fishir $g$ outfit are procured; two suits of clothes, and an indefi. nite quantity of rags (for sores, my landlady says,) are snugly stowed sway in a white clothes-bag. A stock of "Vineyard" stockings, and a few interesting books are duly placed under the mat. 
tress in my narrow berth; and so with a good breeze we get under way.

"The fleet," as the collection of mackerel fishzrmen is called, is known to be off Portland. Thither then we wend our way-slowly enoughwith light winds and calms. The first two or three days out, all hands are busied in preparing fish gear, "Jigs," as the peculiar hooks used to catch măckerel are called, are cast and burnished up; lines are stretched, measured and coiled away; beckets and cleats are placed opposite each man's place at the rail; and these places are fairly portioned off and marked, in order that no confusion may arise when fish are "along side." All these matters duly attended to, and there is room to look about us, and occasion to express impatience at our slow progress toward the fleet.

I presume I ought to describe as nearly as may be, the appearance of the craft in which I now found myself. She was schooner rigged-that is, had two masts, and fore and aft sails. She was a neatly built, sharp little craft of about one hundred and fifty tons burthen. Our crew numbered twelve men besides the cook: The galley, or cooking stove and kitchen generally, was in the forecastle, a narrow and dark little hole, about six by eight feet, exclusive of the berths - which bərths, I may add, were all occupied.

One half the crew slept in the forecastle. The other and older half found their sleeping accommodations in the cabin. This was another con. 
tracted den, about six by ten feet. Its center was completely occupied by a table, from wh ch all hands partook of their food. Locker-seats ranged along the side, fitted tc this table. A $\mathrm{r} w$ of shelves and a box compass and quadrant fill out end; a small coal stove and the hatch ladder, the other. A sky-light overhead gives necessary light. The whole smells villainously of decayed fish.

The hold is filled with barrels, some empty, some full of water, used as ballast. The deck contains naught but a bait-mill, a barrel of bait, and some strike barrels which it is hoped we shall shortly fill with mackerel.

The crew were a set of genuine Cape men. I was the only "stranger" on board. The rest were all born and bred fishermen: quick moving, nervous men in fact, although they seemed, when unexcited, slow enough to please the most lymphatic Hollander. Our captain was a tall, portly man, blue eyed but dark complexioned, and of a fair presence. He was reputed-as he afterward proved himself-the most skillful fisherman on board. His lines and jigs were fitted with the most scrupulous nicety. He had a set for every kind of weather we were likely to experience, from the large line and heavy jig to be used only on fish-days or in rough weather, to the most delicate fly-lines, with minute hooks and jigs, with which to tempt the daintiest of mackerel on smooth days. 
He was a man of infinite patience. In a calm he would lean over the rail for hours at a time, once in a while hauling in a huge mackerel, while the others were lounging idly about decks, or if at the rail at all, were inattentive to thoir lines. $\mathbf{H}$ is exhortations to others to attend to the fish, wore ceaseless, while fish were along side.

"Now they bite, boys; here's a spirt!" ho would cry whenever, by unusual wariness, he succeeded in capturing a mackerel. Then would follow a rush to the rail, a few moments of breathless attention, and finally, "now they don't bite, boys," from some disappointed lounger, as he fell back upon the deck or hatchway. Such was "the skipper," and a better man could not be found to command a fishing vessel. 


\section{CHAPTER XIX.}

"The Fleer"-A Night Scene-The First Day on Fish Ground -Habits of Mackerel-Advantages of being in a Fast Vessel -Why there is a "Fleet"-Method of Taking MackerelBait used-Monotony of the Fisherman's Life-A Fish-dayPremonitory Symptoms-Rain_-"Shorten Up"-Breakfast -Dressing Fish-Making a Harbor-Salting down-Coming to Anchor-After Supper Comforts-The Morning after a 8torm-The Close of the Trip-Depart for New York-I Determine to quit the Sea-and do so-Difficulties Attending such a Change, with the Sailor.

Ir was on the fifth night after leaving our port, that we came into "the fleet." During the day an occasional homeward bounder, steering off with all sail set, had passed us. Toward evening, white sails were visible in many directions. At sunset we were already near the outsiders, the videttes of the fleet. And before retiring to rest we wer in the midst of the vast collection of vessels, their innumerable lights glistening upon the smouth expanse of ocean, and dancing solemnly up anc down on the great swell which the Atlantic ever kecps up, much more resembling the vessels in a vast naval panorama, than a scene of real life.

There is something s slemn and thought-inspiring in a scene like this, at all events to a thinking 
person who for the first time witnesses it. The entire stillness which reigns by night cver this vast aquatic town, the absence of all noise except the continual faint roar of the swell, the sorrowful creaking of the rigging, and the solitary "sug" of the vessel's bow, as she falls into the trongh of the 'sea; the bare poles of the distant vessels thrown in vivid, almost unnatural relief against the sky; the crazy motion of the little barks, as they are tossed about at the mercy of the waves, having scarce steerage way; the lonely-looking light on the mast, seeming to be the spirit which has entire charge of the hull beneath; the absence of all life where but a short time ago all was life and bustle: all this contrasted so strangely with the lively appearance of the vessels by day, as they skim rapidly over the waters, their great piles of snow-white canvas gleaming gayly in the sun, and their crews moving merrily about decks, as to make me almost doubt that there were in fact in the shapeless masses drifting past us, hither and thither, at the mercy of wind and wave, men stout and able, who had often battled for their lives with the same old Ocean upon whose bosom they were now so placidly reposing.

But here comes one, rolling toward us,

"As silent as a painted ship, upon a painted ocean," ai ä seemingly just as likely to hit us as not. nail him.

"Schooner ahoy!"

"Hillo!" is answered by a tall figure which 
starts up from a reclining posture on the com. panion hatch.

"How many mackerel did you get to day?"

"About twenty wash-barrels, mostly large."

"Did the fleet do anything?"

"Some of them lay still a good while, and zuess had pretty good fishing."

Here some of our crew mutter out a weak imprecation upon the weather, which has prevented us from joining the fleet before. Our friend hails us-

"Are you just from home?"

"Yes; all well there."-And the faint sound of the waves as they surge under his bows tells us that we are too wide apart for speaking purposes.

Standing a little farther on, into the thickest of the fleet, we too, about nine o'clock, hauled down our mainsail and jibs, and leaving one man on deck as a look-out, went below to prepare by a sound sleep for the labors of the morrow.

At early dawn we turned out to make sail. Although yet too dark to distinguish the numerous fleet in whose midst we had taken our place, our ears were saluted on all sides by the rattle of ropes, the creak of blocks, and the rustling of car. vas and we were conscious that ten thousand men rere actively employed around us, at the same moment, in the same work, and preparing for similar duties and labors.

As the day breaks, a grand spectacle bursts upon our view. The sky is clear, and' the sun, as he 
rises above the eastern horizon, gilds with his rays the sails of a thousand vessels, as they lie spread out upon the mirror-like surface of the sea. And now our crew begin looking for acquaintances among the vessels. My astonishment is unbounded at hearing them name vessels distant from a quarter of a mile to six or seven miles, and that with perfect certainty of their correctness. To such perfection has practice trained the vision of these men that notwithstanding mackerel catchers are scrupulously rigged alike, the crew would point out not only schooners with which they were acquainted, but also tell the hailing-places of many which they had never seen before.

As an old salt, I prided myself not a little ou my expertness in detecting differences in rig or build, but was obliged here to give up my art as completely beaten. For where I could not detect the slightest distinguishing characteristic, the experienced eyes of one of my companions would at one glance reveal the whole history of the vessel in question, and would enable him to tell, with a certainty which scarcely ever failed, the place where she. was built, where rigged, and where at present owned. This wonderful faculty is the result of keen eyes and long experience, and is found nowhere else in such perfection as among American fishermen.

Lying to for a little while, to try for fish, wo shortly got under way, and stood on with the rest of the fleet. The wind was from North west 
and every one of the nine or ten hundred vessels composing the fleet, are tacked to the Northward. It was curious to watch their motions. They have no head, no organization of any kind; yet do they move as much in concert as would the best urganized naval fleet, working by the signals of their commodore.

See, the headmost vessel of the fleet is in stays. There the next one tacks. Little squads of half a dozen follow suit; and in fifteen minutes the whole fleet is on the other tack, standing to the westward. And so we go all day, working to the windward as fast as the light breeze will bear us along. Every once in a while some one heaves to and tries for mackerel. But mackerel won't bite well, in general, on such a day as this; and this day we don't see a live one at all

Mackerel go in large schools, one of which contains fish enough, if all caught, to fill up every vessel in a fleet. But, vast as such a body is, it occupies but a very small space in the ocean which supports it. A school of fish, therefore, is to be searched out much as one would look for. a needle in a haystack-unwearying patience and determination being qualifications as necessary to constitute a successful fisherman as to make one a fortunate searcher for needles.

T'he fishery is pursued in small vessels, of from thirty to one liundred and twenty tons, and invariably of the "schooner" rig, that is, having two rasts and "fore and aft" sails. The business 
commences in the latter part of March, when tho mackerel first return to our coasts from their winter's absence in more southern waters, and lasts until the end of November. At that time the fish-and of course their pursuers also-have made the entire circuit of our eastern coast, from the capes of Delaware, off which they are first seen in early spring, to the extreme borders of Maine and the bays of British America, and back again as far as the headland of Cape Cod. Thence the fish-about Thanksgiving Day-take their final departure for their as yet undiscovered winter quarters.

All attempts made by enterprising fishermen to follow the mackerel, after they leave "the Cape," have hitherto proved utterly futile, every trace of the vast school which annually congregates there being invariably lost within fifty miles of the south shoals of Nantucket. Many different surmises have been offered to account for their sudden disappearance, and various theories started by those curious in such matters, to explain the why and wherefore of the eccentric motions of a school of mackerel. But the matter is apparently just as much in the dark as ever, and their disappear ance about Thanksgiving time remains as much a subject for speculation as the similar annual disappearance of swallows. Many, wise in such matters, think that the fish, after leaving our coast, lie at the bottom of the sea, in comparatively shjal water, in a s+ate of stupefuctis in until 
the return of warm weather; others suppose that they emigrate to warmer latitudes, wlere they swin. deep beneath the surface, in order to keep themselves in a temperature suited to their nature; and many old fishermen devoutly believe that after leaving us they are, somehow, changed into fish of an entirely different species, and are met. with in the tropical seas as albicores, bonita, etc. All that is known on the subject is, that those which leave the coast at the beginning of winter are of moderate size, but very fat; while those which return in the spring are large, extremely poor, and ravenously hungry.

The vessels in which the fish are pursued and caught, are small, but stoutly built, formed to resist some degree of bad weather, and having, almost invariably, excellent sailing qualities. The latter, indeed, is a necessary qualification in a vessel intended for this business, as the success of a voyage, in many instances, depends on a vessel getting to a certain place, where fish have been discovered, an hour sooner or later.

Thus, it once happened that the entire fleet took shelter in Cape Ann harbor, on occasion of a storm. After lying in port two days the weather mciderated. Early the following morning the flet got under way. The first little squad of about a dozen vessels, manned probably by the incst eager fishermen, but consisting also of the fastest sailing scha'ners, had about forty minutes start of the balance. It was a beaut ful morning 
A very light breeze prevailed, before which none but the sharpest vessels could make headway. These had hardly gotten clear of the lanci, when they "struck" mackerel. They at once "hove to," and did not again get under way until their decks were filled-the fish biting all this time as fast as they could be hauled in. Meantime, the slower moving portion of the fleet had just time to reach the harbor's mouth when the little breeze which had carried them thus far died away, and it fell a dead calm; and they were actually forced to lie there, within four or five miles of a vast school of fish, and in plain sight of their more fortunate companions, without feeling a bite.

"The fleet" is an aggregate of all the vessels engaged in the mackerel fishery. Experience has taught fishermen that the surest way to find mackerel is to cruise in one vast body, whose line of search will then extend over an area of many miles. When, as sometimes happens, a single vessel falls in with a large "school," the catch is of course much greater. But vessels cruising separately or in small squads are much less likely to fall in with fish than is the large fleet. "The fleet" is therefcre the aim of every mackerel fisherman. The best $v$ cissels generally maintain a position to the windward. Mackerel mostly work to windward slowly, and those vessels farthest to windward in the fleet are therefore most likely to fall in with fish first; while from their position they can quickly run down, should mackerel be raised to leeward. 
Thus in a collection of from six hundred to a thousand vessels, cruising in one vast body, and spreading over many miles of water, is kept up a constant although silent and imperceptible com. munication, by menns of incessant watching with gond spyglasses. This is so thorough that a vessel at one end of the fleet can not have mackerel "alongside," technically speaking, five minutes, before every vessel in a circle, the diameter of which may be ten miles, will be aware of the fact, and every man of the ten thousand composing their crews will be engaged in spreading to the wind every available stitch of canvas to force each little bark as quickly as possible into close proximity to the coveted prize. And then commences the trial of speed. Then the best helmsman is called to steer; every eye watches the sails, to see that they draw well, and every hand is ready to jump to remedy any defect. Then is the anxious moment for fishermen; for they see spread out before them a vast school of fish, in the midst of which lie the few favored vessels which have succoeded in raising them, and are now reaping a golden harvest. This is indeed the most exciting scene in the experience of a mackerel catcher. The fish are caught with hook and line, each fisherman using two lines. When hauled on board, they are "struck" off by a peculiarly quick motion of the right hand and arm, into a "strikg barrel" standing behind and a little to the right of its proprietor. The same motion which leave 
the maskerel in the barrel also suffices to project the hook (which has a little pewter run on its shank) back into the water, and the fisherman immediately catches up his other line, going through the same maneuver with it. So ravenously do the fish bite, that a barrel full is some. times caught in fifteen minutes by a single min.

The bait used to entice them alongside, and keep them there afterward, consists of a mixture of clams and a little fish known by the euphonious name of "porgies." The last are seined in great quantities every summer in the mouth of the Connecticut river, and the adjacent waters, and are used by farmers as manure for their land, as well as by mackerel catchers as bait. This bait is ground up fine in a mill provided on board for the purpose, and is then thrown out on the water. It sinks to the depth at which the fish lie, when they, in their eagerness for it, follow it up until they get alongside the vessel. Once alongside, thoy bite indiscriminately at bait or naked hook.

Life on board a "mackerel catcher" is very monotonous. There is literally nothing to do. One man who can steer can work the craft all day. The sails are so arranged that in tacking they work themselves. The hands do therefore what they please. Some sleep, some read, some talk over old times, and a few old fishermen sit upon the quarter, hour after hour, spyglass in hand, watching, the fleet and wishing for fish.

Somo days we ratch a few mackerel; some days 
we do not see a "live one," but tack and tack to windward all day long, glad when the setting sun proclaims the time for "heaving to" and going bolow to sleep. After more than a week of this kind of life, there comes a day when fishermen begin to" prophecy the approach of a "regular fish day."

All day the wind is light and baffling, while a swell comes rolling in from the eastward, which makes our little vessel tumble about strangelysails slatting, and blocks creaking mournfully in the calm.

Toward evening the wind goes down, the sky is crercast by white clouds, and the weather becomes a pea-jacket colder. Having found no fish all day, we take in sail early, see everything clear for a "fish-day" to-morrow, and, all but the watch (one man), turn in about eight o'clock.

At midnight, when I am called up out of my warm bed to stand an hour's watch, I find the vessel pitching uneasily, and hear the breeze blowing fitfully through the naked rigging. Going on deck I perceive that both wind and sea have "got up" since we retired to rest. The sky looks lowering, and the clouds are evidently surcharged with rain. In fine the weather, as my predecessor on watch informs me, bears every sign of an excellent fish-day on the morrow. I accordingly grind sume bait, sharpen up my hooks once more, see my lines clear, and my heaviest jigs (the tech. nical term for hooks with pewter run on them), 
on the rail ready for use, and at one o'clock return to my cornfortable bunk. I am soon again asleep, an 1 dreaming of hearing fire-bells ringing, and seeing men rush to the fire; and just as I see "the machine" round the corner of the street, am start. led out of my propriety, my dream, sleep, and all, by the loud cry of "Fish ho!"

I start up desperately in my narrow bunk, bringing my cranium in violent contact with a beam overhead, which has the effect of knocking me flat down in my berth again. After recovering as much consciousness as is necessary to appreciate my position, I roll out of bed, jerk savagely at my boots, and snatching up my cap and peajacket, niake a rush at the companion way, up which I manage to fall in my haste, and then spring into the hold for a strike-barrel.

And now the mainsail is up, the jib down, and the captain is throwing bait. It is not yet quite light, but we hear other mainsails going up all round us. A cool drizzle makes the morning unmistakably uncomfortable, and we stand around half asleep, with our sore hands in our pockets, wishing we were at home. The skipper, how. ever, is holding his lines over the rail with an air which clearly intimates that the slightest kind of a nibble will be quite sufficient this morning to seal the doom of a mackerel.

"There, by Jove! the captain hauls hackthere, I told you so ! skipper's got him-no-aba captain, you haul back too savagely!" 
With ihe first movement of the captain s arm, indicating the presence of fish, everybody rushes madly to the rail. Jigs are heard on all sides plashing into the water, and eager hands and arms are stretched at their full length over the side, feeling anxiously for a nibble.

"Sh-hish-there's something just passed my fly-I felt him," says an old man standing along. side of me.

"Yes, and I've got kim," triumphantly shouts out the next man on the other side of him, haul' $\mathrm{ig}$ in as he speaks, a fine mackerel, and striking aim off into his barrel in the most approved style.

Z-Z-zip goes my line through and deep into my poor fingers, as a huge mackerel rushes savagely away with what he finds is not so great a prize as he thought it. I get confoundedly flurried, miss stroke half a dozen times in hauling in as many fathoms of line; and at length succeed in landing my first fish safely in my barrel, where he flounders away "most melodiously," as my neighbor says.

And now it is fairly daylight, and the rain, which has been threatening all night, begins to pour down in right earnest. As the heavy drops patter 'on the sea the fish begin to bite fast and furiously.

"Shorten up," says the skipper, and we shorten in our lines to about eight feet from the rail to the hooks, when we can jerk them in just as fast as we can move our hands and arms. "Keep 
your lines clear," is now the word, as the doomed fish flip faster and faster into the barrels standing to receive them. Here is one greedy fellow already casting furtive glances behind him, and calculating in his mind how many fish he will have to lose in the operation of getting his second strike-barrel.

Now you hear no sound except the steady flip of fish into the barrels. Every face wears an expression of anxious determination; every body moves as though by springs; every heart beats loud with excitement, and every hand hauls in fish and throws out hooks with a methodical precision, a kind of slow haste, which unites the greatest speed with the utmost security against fouling lines.

And now the rain increases. We hear jibs rattling down; and glancing up hastily, I am surprised to find our vessel surrounded on all sides bJ the fleet, which has already become aware that we have got fish alongside. Meantime the wind rises, and the sea struggles against the rain, which is endeavoring with its steady patter to subdue the turmoil of old Ocean. We are already on our third barrel each, and still the fish come in as fast as ever, and the business (sport it has ceased to be ome time since), continues with vigor undiminเshed. Thick beads of perspiration chase each other down our faces. Jackets, caps, and even orer-shirts, are thrown off, to give more freedom to limbs that are worked to their utmost
"Hillo! where are the fish?"
All gone?
Evory 
line is felt eagerly for a bite, but not the faintest nibble is perceptible. The mackerel, which bui w moment ago were fairly rushing on board, liave in that moment disappeared so completely that not a sign of one is left. The vessel next undey our lee holds them a little longer than we, but they finally also disappear from her side. And so on all around us

And now we have time to look about us-to compare notes on each other's successes-to straighten our back bones, nearly broken and aching horribly with the constant reaching over; to examine our fingers, cut to pieces and grown sensationless with the perpetual dragging of small lines across them-to- "There, the skipper's got a bite!-here they are again, boys, and big fellows too!" Everybody rushes once more to the rail. and business commences again, but not at so fast a rate as before. By-and-by there is another cessation, and we hoist our jib and run off a little way, into a new birth.

While running across, I take the first good look at the state of affairs in general. We lie, as before said, nearly in the center of the whole fleet, which from originally covering an area of perhips fifteen miles each way, has "knotted up" into a little space, not above two miles square. In many places, although the sea is tolerably rough, the ressels lie so closely together that one could almost' jump from one to the other. The greatest skill and care are necessary nn such occasions to keop 
them apart, and prevent the inevitable consequen. ces of a collision, a general smash-up of masts, booms, bulwarks, etc. Yet a great fish-day lika this rarely passes off without some vessels sustaining serious damage. We thread our way umong the vessels with as much care, and as daintily as a man would walk over ground covered with eggs; and finally get into a berth under lee of a vessel which seems to hold the fish pretty well. Here we fish away by spells, for they have become "spirty," that is, they are capricious, and appear and disappear suddenly.

Meanwhile the rain continues pouring out of the leaden sky, which looks as though about to fall on us, and overwhelm us in a second deluge. The wind is getting high; and the old hands are debating among themselves as to the most judicious port to be made to-night. At ten we get breakfast, consisting of coffee, hot cakes, bread and butter, fish, beef, sweet cakes, and apple sauce. The morning's exercise has given us all a ravenous appetite, and the celerity with which the various comestibles spread out for us by the cook are made to disappear, would astonish ? dyspeptic.

After breakfast, we begin to clear up decks a little, preparatory to experiencing some part of the rough weather which is brewing. Oil clothes are in great demand, but the rain somehow contrives to soak through them, and they form but little protection. We sicure our mackerel bariels 
to the bulwarks, lash up the various loose objects about decks, and put on the hatches. The fish still bite, but more moderately, and by "spirts," and in the half liquid state in which we all find ourselves, we mechanically hold our lines over the rail and haul in fish with as little motion to ous bo ies as possible; for the skin in such weather gets marvelously tender, and is apt to rub off on rery slight provocation.

At one o'clock "Seat ye, one half," from the cook, proclaims dinner on the table, and "one half" accordingly go down to "finish their break. fast," as a facetious shipmate remarks. The cabir. of a fisherman be it known is too confined tc accommodate an entire fishing crew with seats around the table, and accordingly it is customary for the oldest hands to eat first, leaving the young men and boys to follow at second table.

After dinner we make preparations for dressing our fish. Gib-tubs, split-knives, barrels, washbarrels, buckets, mittens, and sea-boots, are hunted up, and water begins to flow about decks more plentifully than ever. Mackerel are "dressed" by splitting them down the back, taking out their entrails (called in fishermen's parlance "gibs"), clearing them of blood by immersion in salt water, and then salting them down in layers, in the bar rels prepared for that purpose.

'Two persons compose a "gang" for dressing. One of them splits the fish and throws them to the other; who by a dexterous twist of his thumb 
and the fingers of his right hand, extracts the entrails and throws the cleaned fish into a barrel of salt water at hand. "Dressing" fish is disagreeable work in itself, but generally passe off lively enough, as it is the concluding scene m what fishermen call "a day's work." One now learns how much he has in reality caught, and miser-like plunges up to the armpits in the riches he has that day won. Then too, dressing is enlivened by many a jest, and anecdote, and song, every body feeling joyful at the events of the day, and hopeful for the success of the voyage. And while the operation of catching fish is followed with an intensity and ardor which does not admit of the slightest flagging of attention, dressing is the very reverse, and may be made as lively as possible without detriment to the work.

Soon after commencing to dress, the whole fleet gets under way, and steers toward the land, which is faintly visible under our lee, the wind being from the northeast. Going square before it, we soon near the land, and as we do so, both wind and sea increase. We have a grand chance to try the sailing qualities of our little boat--a shance which a mackerel man never neglects; for next to getting a good share of fish, a man is considered most fortunate if he has a smart sailing vessel. We overhaul a good many, and are badly beaten by a few of the vessels, as might bo expected in so large a fleet. And as we come into competition with some new vessel, 
our crew tell at once her name, if she ss known to them, or if entirely unknown, at any rate her hailing place.

After dressing, we salt our catch. This is sorry work for sore fingers, hands, and arms, of which, after a day's work like the present, there is always a plentiful supply, mackereling being under any circumstances a business in which sores of all kinds on hands and feet are singularly plenty and hard to get rid of. But salting does not last forever, and the few preparations for going into harbor being already completed, we gather together, as dusk comes on, in little knots about the deck, discuss the day's work, point out familiar vessels, and argue on their various sailing qualities, and once in a while slily peep down the "comparion-way" into the snug little cabin, where the "ram-cat" (the sailors' name for a cabin stove) glows so brightly, and every thing looks so comfortable, and in particular so dry, that our hearts yearn for a place by the fire. Landsmen, poor fellows, have no idea how great an amount of real, unmistakable comfort may be contained in a little box eight feet by twelve, with a table in the middle, seats and berths at the sides, a stove and hatchway at one end, a row of shelves and a box-compass at the other ana a skylight over head, the whole smell. irg villainously of decayed fish and bilge-water. Happily for mankind, all happiness is compara. tive, else would not the dirty, confined cabin of a fishermar erer be considered a very Elysinm of 
comfort, and a seat by its fire be regarded as a luxury, than which the conqueror of the world can wish for nothing better.

We are fast nearing our haven. And glas slough we all are of it, for the wind has risen until. it already blows half a gale, and the great waves roll after us savagely, trying to overtake us', and looking as though if they did, they would inevitably smother our little craft. And then too, as the excitement of the day dies out, and we stand inactively about, the rain seems colder, and our wet clothes adhere clammily to our bodies, and make moving about a misery. Yonder is East Point Light shining brightly on our beam. The headmost of our companions have already shot around the point, and are running up to their anchorage.

"Man your sheets now, boys, and stand by to trim aft!" sings out our skipper. As we string along the ropes the helm goes down. She comes into the wind, shaking like a dog just come out of the water, and at the same time the sails are trimmed flat, and we gayly round the point. In less than fifteen minutes we are in smosth water.

Two tacks take us nearly.up to Ten Pound Island Light, and as we stand over once more,

"Haul down the foresail!" shouts the captair. "Stand by your main and jib halyards! see your anchor all clear!"

"There's a good berth, skipper," says one of 
the old hands, "right alongside of that Chatinam smack." (It is so dark that, do my best, I can not make out even the rig of the vessel to which my old friend so readily gives a "local habitation and a name."

Here we are-down jib!" and down it rattlen without any trouble, as her head swings into the wind. As her headway is deadened, "let go the anchor !" is the word, and a plash, and the rattle of a few fathoms of cable tell us that we are fast for the night.

"Pay out cable, boys; a good scope, and let her ride easy!" and the rest of us go aft and haul down the enormous mainsail, the wet can. vas of which feels as though made of stout wire. It is soon furled up, and a lantern fastened in the rigging, and then we make a general rush for the cabin. Here wet clothes and boots are flung off and thrown pell mell on deck; dry suits donned, and then "one half" crawl into their bunks, while the balance eat their suppers.

Meanwhile we hear an incessant rattling of sails and plashing of anchors on every side of us, while the wind whistles wildly through our rigging, and the rain dashes fiercely against the skylight and deck overhead, increasing our comfort by reminding us of the sufferings we havo escaped.

It is not until after supper that we begin to think of the damages sustained in our persons during the past day's work. And now rags, 
salve, and liniment, and all the various preparations for ameliorating the condition of sore fingers, sore wrists, sore arms, sore feet, sore ankles, and sore shins, are brought into rcqursition; the cook is flattered and cajoled out of modicums of hot fresh water; and stockings are taken off, sleeves rolled up, bandages unrolled, and groans and growls resound from overy corner of the cabin.

Before retiring to rest I take a peep on deck. The gale is roaring fiercely through the bare rigging, and a blinding storm of hail and sleet, a blast of which salutes my face as I put it out of the companion-way, adds to the inclemency of the night. The dark storm-clouds scud wildly across the sky, and the wind fairly shrieks at times, as though glorying in the strength to bear down everything coming in its path. It is truly a wild night, and as I descend again to my comfortable place by the fire, I think anxiously of the poor souls who are tossed about in such weather-cold, wet, and suffering at the mercy of the winds and waters. I am not alone in my thoughts, for as I shake the sleet off my rough cap, I hear our grayheaded old skipper mutter softly to himself, "God pity poor sailors who are caught in Boston Bay in this storm."

We go to sleep early-get up late next morning -get breakfast-(the storm still raging)-head up, and strike down the mackerel caught the pre. coding day; clear up decks, and then go ashore of 
visit some of the other vessels. To do either of the latter, we do not require the assistance of boats, for the fleet has so crowded the harbor, that one can without difficulty walk from one side of the harbor to the other, a distance of threefourths of a mile, on vessels.

Toward evening the wind hauls to the north. xard, the weather clears up, and great snow-white clouds, looking like gigantic puffs of steam from some engine in the other world, roll grandly across the sky, sure signs of good weather. We "turn in" early, and are called out at three o'clock A. M. to get under way. We find every body around us in motion, some heaving up their anchors, others hoisting their sails, some with boats ahead, being towed out of the crowd, so as to enable them to shape a course, and a fow already steering out of the harbor. We follow suit with all haste, and daylight finds us in Boston Bay, with the fleet around us, and the hills of Cape Ann blue in the distance.

Such is a fish day, with its accompaniments. Of a series of such, with the intervening periods of idleness, our trip was composed. It would be tedious to enter into a narrative of the voyage, therefore. Sufficient understanding of the delights and discomforts of the business will be gained by what I have recounted. Our first trip lasted five weeks. In that time we filled up every barrel on board. Returning to Harwich, we landed our cargo. Here the fish were assorted, 
packed and weighed; and the barrels finally branded to show that they contain " $200 \mathrm{lbs}$. mack. erel," No. 1, 2, or 3, as the case may be. After four days detention, we set out upon another trip. This time we were four weeks in filling up our vessel. It was now getting cold. So upon our second return to port, I left the vessel, received the returns for my labor, and with about forty dollars in my pocket, took passage in a schooner bound to New York.

Shall I now make my pre-determined attempt to remain ashore? was a question which incessantly engaged my mind. It seemed almost like a vain hope; but I finally determined to make at least one strong effort. If that failed-it would be time enough to think what should be done afterward On my arrival in New York I procured myself some "shore clothing," and for some days dili. gently sought a situation of some kind. It was not till this search for employment began, that I was made fully aware how utterly useless a sailor is for aught, except the most severe physical toil, on shore. It was only now I began to suspect that the habits of the ship had taken such entire possession of me as to unfit me for any other life than that of a sailor. Yet "a trial shall be made," thought I. In New York I had no friends. Wherever I applied for employment, I was asked for references. Having none, it would next be asked, "What did you do last?", An acknowlodgment that I had been a seaman was alwayn 
productive of a speedy annihilation of my hopes. "I would like to take you," said the kindest man t) whom I had occasion to apply, "but a sailor, sou know, would never do for me. 'You would not remain a month at any steady employment."

After a week spent in vain applications in New York, I shipped in a brig for Philadelphia. Here I was kindly but suspiciously received by good people who had befriended me when I first set out from home to go to sea. What struggles were necessary before I was able, even here, with the assistance of friends, to gain a firm footing; how I was on every hand met with suspicion and distrust; how no one could believe that I would remain steadily ashore; and how this very unbelief led me oft-times to think seriously of returning 10 my sea-life-doubting myself, because others doubted me-none of this need be more than mentioned here. Suffice it, that by a persistent effort, and a struggle through which I would not like again to pass, I at length proved to doubting friends that there is redemption for even a sailor.

But to this day my firmest friends mildly doul $t$ the permanency of my shore life. Shall I owuis that I sometimes see that in a sailor's cixisten's which is preferable to some lives on land? 




\section{THIS BOOK IS DUE ON THE LAST DATE}

STAMPED BELOW

\section{AN INITIAL FINE OF 25 CENTS} WILL BE ASSESSED FOR FAILURE TO RETURN THIS BOOK ON THE DATE DUE. THE PENALTY WILL INCREASE TO 50 CENTS ON THE FOURTH DAY AND TO \$1.0O ON THE SEVENTH DAY OVERDUE.

\begin{tabular}{|c|c|}
\hline  & \\
\hline MAR2 3 1954L!! & \\
\hline EArrGar? & \\
\hline REC'D Li & \\
\hline APR $7{ }^{\prime} 64-12$ & \\
\hline SEP 2319534 & \\
\hline RECEIVED & \\
\hline  & \\
\hline $\begin{array}{r}\text { REC'D LD OCT } 20^{\circ} \\
\text { MAY } 17197 \\
\text { REC'D LD MAY }\end{array}$ & $\begin{array}{l}72-2 \text { PM } 12 \\
733^{1} \\
14^{7} 73^{-2} \text { PM } 90\end{array}$ \\
\hline AUG $191984=$ & APRI 41990 \\
\hline REC.CCIR 9 & \\
\hline
\end{tabular}




\section{U.C. BERKELEY LIBRARIES



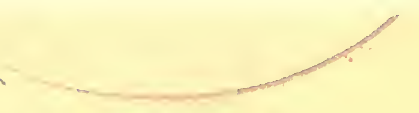

\section{$\overline{\mathrm{N}} 123588$}



THE UNIVERSITY OF CALIFORNIA LIBRARY 
(6)



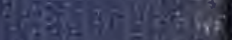

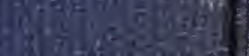
.

.
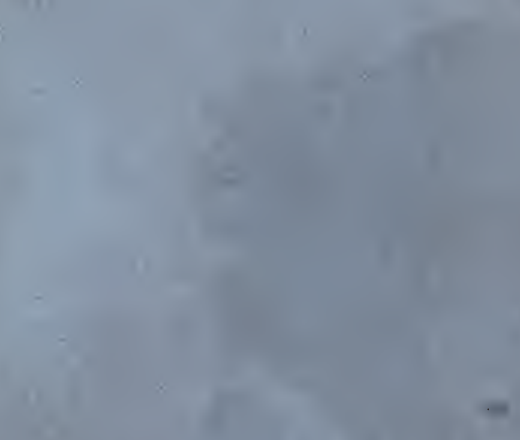